\title{
The Green Republic: A
} Conservation History of Costa Rica, 1838-1996

\section{Part 1}

\author{
by Sterling Evans \\ B. A., Anderson University, 1981 \\ M. A., University of Kansas, 1992
}

Professor in Charge

Charles L. Stansifer

Committee Members

Donald Worster

Elizabeth Kuznesof

The University of Kansas has long historical connections with Central America and the many Central Americans who have earned graduate degrees at KU. This work is part of the Central American Theses and Dissertations collection in KU ScholarWorks and is being made freely available with permission of the author through the efforts of Professor Emeritus Charles Stansifer of the History department and the staff of the Scholarly Communications program at the University of Kansas Libraries' Center for Digital Scholarship. 


\title{
THE GREEN REPUBLIC: A CONSERVATION HISTORY OF COSTA RTCA, 1838-1996
}

\author{
BY S. EVANS
}




\section{THE GREEN REPUBLIC:}

A Conservation History of Costa Rica, 1838-1996

Part 1

by

Sterling Evans

B.A., Anderson University, 1981

M.A., University of Kansas, 1992

Submitted to the Department of History and the Faculty of the Graduate School of the University of Kansas in partial fulfillment of the requirements for the degree of Doctor of Philosophy.
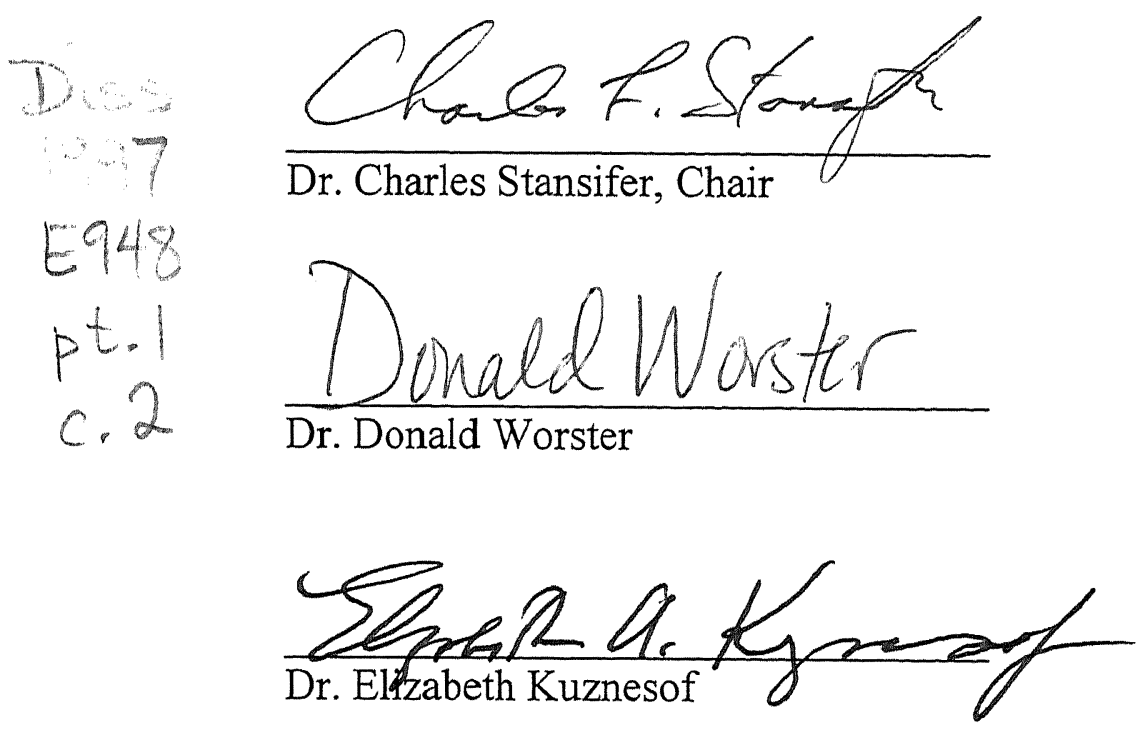

$$
1 / 24 / 97
$$

Date Submitted 
ABSTRACT

THE GREEN REPUBLIC:

A Conservation History of Costa Rica, 1838-1996

\begin{abstract}
Costa Rica is often cited as a "model" for environmental conservation. This dissertation seeks to track the history of conservation efforts in Costa Rica via analysis of the development of its national parks and other protected areas. The focus of the work will be on discussing how Costa Rica came to establish its conservation system which today includes over twenty-five percent of the country's terrain. It will describe the system, discuss key leaders involved, and analyze conservation in light of what it was in response to: rapid destruction of tropical ecosystems due to the expansion of exportrelated agricultural commodities. How and why were national parks and biological reserves proposed and designated? Who has been behind them? Why and how did these individuals become involved in their country's conservation movement? What has been the overall impact of conservation on the nation's environmental well being, economy, and education? What challenges have conservationists had to confront; what goals and dilemmas await them? Importantly, the work will address what costa Ricans have said and are saying about these conservation concerns. Emphasis will be placed on policy reactions--laws and decrees and how they came about.

To limit the scope of this project, "conservation" here will imply the creation of national parks, biological reserves, national wildlife refuges, and indigenous reserves that have been set aside for long-range preservation for future generations. While there have been many works written about Costa Rica's national parks, what is missing is a historical work that links development of conservation patterns with agricultural and political history. The intent of this dissertation is to show how conservation policy came about, how leaders in the movement worked to forge changes, and how conservation thought has evolved from the early days of Costa Rican independence to 1996.
\end{abstract}

- Sterling Evans 


\section{PREFACE}

Esta tierra pertenece a los costarricences, algunos ya han muerto, otros todavía viven, pero la mayoría - . aún no ha nacido.

- anonymous

(This land belongs to the Costa Ricans, some have already died, others are still living, but the majority. . has not even been born.)

The vision exemplified in the above oft-quoted saying makes Costa Rica an intriguing case study in environmental history. Its implied message, that costa Rica is a country with a mind for the future-a future based on the environmental well-being of its land and inhabitants--begs the question of how such a model developed and what measures have been instituted to ensure its success. More implicitly, this idea must be tested by tracing the successes and failures of the Costa Rican conservation experience. Such analysis is the goal of this work. Does Costa Rica live up to its nickname "the garden of the Americas?" Does it embody what New York Times writer John Oakes in 1988 called the "greening" of the region? Is it on the path of what a conference that same year concluded was toward a Centroamérica verde? Is Costa Rica a "green" republic?

To attempt answering such questions, this dissertation seeks to track the history of conservation efforts in Costa Rica via analysis of its national parks and other protected areas. The focus of the paper will be on discussing how Costa Rica came to establish its conservation system which today includes over twenty-five percent of the country's terrain. It will describe 
the system, discuss the key leaders involved, and analyze conservation in light of what it was in response to: rapid environmental destruction of tropical ecosystems due to the expansion of export-related agricultural commodities. How is this agricultural modernization different from past agricultural experiences and how has it affected conservation efforts? What conservation measures or agricultural practices from the nineteenth and early twentieth centuries influenced conservation patterns? How and why were national parks and biological reserves proposed and designated? Who has been behind them? Why and how did these individuals become involved in their country's conservation movement? What has been the overall impact of conservation on the nation's environmental well-being, economy, and education? What challenges have conservationists had to confront; what goals and dilemmas await them? Importantly, the paper will ask what Costa Ricans have said and are saying about these conservation concerns. Emphasis will be placed on policy reactions-laws and decrees and how they came about. Thus, the project will evaluate the so-called "model."

Only two other works approach this subject in book form. The first, Luis Fournier's Desarrollo y perspectiva del movimiento conservacionista costarricense (1991) lists some of the early conservation policies and discusses the beginning of Costa Rica's conservation movement. But while written from the perspective of someone who was actively involved in conservation policy making, the book is a rather short condensation of conservation laws and 
the people behind them with little analysis or in depth discussion. Dr. Fournier's intent for the book was to be introductory-he provided directions for future research for which I am forever grateful.

The other book is David Rains Wallace's The Quetzal and the Macaw: The Story of Costa Rica's National Parks (1992). Wallace's work is limited, however, to the "story" of national parks only, includes no archival data, and does not put national park development in the larger context of Costa Rican conservation history. Its strength lies in the interviews Wallace incorporated into The Quetzal and the Macaw's narrative--interviews that I have drawn upon here since the voices of the people involved (some of whom I also interviewed and some I did not) are important to be heard in this conservation history. I have duly cited Wallace's work where used, but have attempted to be broader in historic range, more comprehensive in conservation policy making, and more reliant on archival records and newspapers than the Quetzal and the Macaw intended to be. I have also drawn on many articles and essays written by Costa Ricans and others that pertain to individual aspects of conservation policy. Those sources helped greatly in piecing together the larger picture. To limit the scope of the project, "conservation" here will imply the creation of governmental and private areas of land (national parks and monuments, biological reserves, wildlife refuges, indigenous reserves, and private ecological reserves) that have been set aside for long-range preservation. This 
project will not address in any great length such environmental concerns as pollution, urban sprawl, toxic wastes, air and water quality, sanitation, or human health issues. These important matters have a literature all their own and exceed the boundaries of this particular conservation history. Nor is this work a comparison of Costa Rican conservation efforts with those of other republics in the region (although unique features of Costa Rica's geography, history, and society will be weighed vis-à-vis conservation successes.) Rather, this work is an attempt to synthesize diverse elements of Costa Rica's past (natural history, government, education, etc.) to evaluate the successes and failures of the nation's conservation system.

Costa Rican botanist and long-time conservation proponent Luis Fournier has written that "in reality, we are no longer just a few people clamoring for a rational use of the environment, and what in the past for many was merely a romantic or utopian dream, has been transformed into something vital for the future of the country, and is coming to be understood by a greater number of Costa Ricans." The intent here is to follow the development of this Costa Rican pattern of thinking. Disagreement exists whether this is a long, historic phenomenon--pre-dating and including the colonial era--or if it is a recent product of late twentiethcentury scientific understanding. Some scholars point to the ecologically sustainable ways of pre-Columbian native peoples in Costa Rica as a base for an enduring environmental awareness. Others note that farmers in the colonial and early national eras 
practiced responsible agriculture and thus continued a conscien5

tious land use pattern.

Some researchers, however, suggest that environmental awareness has resulted only in the past twenty-five years. Estrella Guier, the director of environmental education at UNED (the Universidad Estatal a Distancia, usually translated as the National Open University) remarked: "It is only recently that a conscience among some towards a rational and balanced exploitation of natural resources has been created." Dr. Fournier agrees: "Fortunately in the [1970's]. . . in Costa Rica there has been a change of attitude in the people. . with respect to the problem of the environment."

Both sides will be examined herein. But has Costa Rica managed its natural resources rationally, and if so, what mechanisms (structural and attitudinal) have proven successful and are in place to continue the trend?

To address these concerns, this work is divided into two parts: I. Costa Rica's history of conservation, and II. the country's framework for what will be called "building a green republic." Emphasis in Part I is placed on such issues as the legacy of tropical research, the environmental dilemma of Costa Rican agriculture, and the conservationist response via public lands management--especially stressing the role national parks have played in the Costa Rican conservation strategy (Chapters one through Five). Surprisingly, a large percentage of public land was protected during the severe economic crisis of the early 1980's. Re- 
porting how this unique, perhaps paradoxical, experience transpired is discussed in Chapter Six and the government's push to restructure and decentralize conservation efforts in the late $1980 \mathrm{~s}$ and $90 \mathrm{~s}$ is discussed in Chapter Seven.

Part II examines other aspects of Costa Rica's conservation experience and how they apply to the structure in place for the future. Analysis of the important roles played by environmental education and non-governmental organizations occurs in Chapters Eight and Nine. Campesino and indigenous movements are important dimensions of the overall story and are included in Chapter Nine. And more recent phenomena such as ecotourism and biodiversity inventorying are discussed in Chapters Ten and Eleven.

But to quote a Spanish proverb, all that glitters is not gold. This work would be terribly remiss and blind to the facts if it omitted a discussion of the serious challenges facing costa Rica's environmental model. What is often called "the grand contradiction" is the paradox of Costa Rica's development of an extraordinary national park system simultaneous to massive deforestation in unprotected areas. The fact that only since 1969 more than twenty-five percent of Costa Rica has been protected in one form or another must be balanced with the fact that over sixty percent of the country is deforested and that the rate is growing by four percent a year. Equally disturbing is that seventeen percent of the land is composed of highly degraded or seriously eroded soil rendering it almost useless for agriculture or for reforestation. 
Keeping things in perspective, however, is important. Oliver Wendell Holmes is credited with the thought that where things are now is less important than the direction in which they are going. And therein lies the hope for costa Rica. In their growing conservation ethic and respect for nature, the people of costa Rica have been motivated for a change in direction to preserve their natural heritage. The history of how this occurred, then, merits attention and is the underlying purpose of this study. In his conservation history of Mexico, Lane Simonian has written that environmental history should become "more international in scope." "In many places, people have fought to protect nature," he continues, and "[t]heir stories should be told. . ." what follows is the account of many who have worked to make Costa Rica a green republic--a country that conserves natural resources for those who have yet to be born. 


\section{ACKNOWLEDGMENTS}

This dissertation is indebted to the visionary people of Costa Rica who have strived with fierce resolve to protect their peaceful corner of the tropical world. The author is grateful to the various individuals who agreed to be interviewed in conjunction with research for this study. Among them are Karen Olsen de Figueres, former President Rodrigo Carazo, Mario Boza, Alvaro Ugalde, Gerardo Budowski, Luis Fournier, Alexander Bonilla, Roxana Salazar, María Eugenia Bozzoli, Eric Ulloa, Jorge Cortés, Alvaro León, Mario Alvarado Sánchez, and Anselmo Flores Reyes. They gave willingly and generously of their time (most on short notice) to open their homes or offices to me.

The staff at the National Archives in Zapote was especially friendly and helpful. I sincerely appreciate all the assistance given to me there by Joel Fallas, Danilo Meléndez, and especially Orlando Castillo who shared not only his expertise of the archival system, but also his time as a sounding board for some of my ideas. Equally cheerful were staff members at the Archives of the Legislative Assembly in San José. There, Olman Madrigal was of great assitance, and the department chief, Leonel Núñez Arias, practically held my hand as I groped to understand the bewildering legislative strata of forestry policy.

Staying in Costa Rica is always a pleasure. People like Zoraida Aparicio, Marta Alvarado, Carl Stanley, and Xenia Murillo made extended stays ever the more enjoyable. (And extra thanks 
go to Marta and Xenia who helped entertain my daughter so well during afternoons in summer 1996.) A special thanks to Willy Solano should be expressed for his personal tour of north central Costa Rica back in 1992 and for his friendship over the years.

Stateside there are many people who have greatly assisted me and have had a hand in shaping this study. Special appreciation goes to the thesis "team" at the University of Kansas since it was there that this project originated: Dr. Charles stansifer (thesis director, who has given countless hours of time and much advice), Dr. Donald Worster (whose work, courses, and colloquia have motivated me to continue pursuing the study of environmental history), and Dr. Philip Humphrey (whose class and discussions on biodiversity helped stimulate research for this project). When the thesis turned into the dissertation, I was pleased that Dr.'s Stansifer and Worster continued to stay on and to be actively involved in the process of finalizing it. I equally appreciate the time, advice, and recommendations of the other three readers, Dr.'s Elizabeth Kuznesof, donna luckey, and John Augelli, whose input has strengthened the final manuscript. I also thank Lane Simonian, an outside reader on an earlier version of this project, who offered very valuable assessments on ways to improve the manuscript. It is I, however, who remain solely responsible for any errors or omissions herein.

My parents deserve special recognition for very actively opening my world to the joys of travel, camping, hiking, and visits to national parks when I was a boy (and for putting up 
with me on such trips when I was assuredly an unpleasant juniorhigh traveller!). They have warmly encouraged me in all research endeavors. Also I thank Dr. John Goodman and Jeanne Goodman on whose tropical ecology trip to Mexico and Central America when I was an undergraduate student stimulated my interest in this area and is in great part the reason for my career direction now. Likewise, thanks goes to Scot Vink, an undergraduate research assistant, former student of mine, and close friend from K.U., who accompanied me on two different trips to Costa Rica and assisted me in many ways.

Finally, a very special thanks goes to Sheri Little Evans (who knows more about writing than I ever will), for her incredible patience and unwavering support through the many stages of this project. I am also indebted to our daughter Alex, who hastened the dissertation's completion with her wonderful interludes of fun, play, and "stories," and who always seemed to tolerate why "Daddy's working the buttons." 
TABLE OF CONTENTS

Preface -

Acknowledgments _ ix

Table of Contents - xiv

List of Figures and Tables _- xvi

Introduction: The Costa Rican

Uniqueness Factor - 1

PART I: Costa Rica's History of Conservation----- 10

Chapter 1: The Legacy of Scientific Thought and Tropical Research - 11

Chapter 2: The Environmental Problem 39

- An Historical Setting

- The Agricultural Dilemma

- Deforestation

Chapter 3: The Conservationist Response

- An Overview of the Costa Rican

National Park Experience

- Early "Parks" and

Conservation Laws

- Legislating Protection:

The Ley Forestal

Chapter 4: The Development of National Parks and Protected Areas

- "A Thousand and One Tricks"

- "A Towering Responsibility:"

The Early Years of National

Park Development

Chapter 5: Conservation Continued:

The Oduber Administration --_ 156

- "The Greatest Friend the

National Parks Ever Had"

- The SPN 
Chapter 6: Conservation through Crisis _-.._- 186

- "Obstacles Became Opportunities:"

The Economic Crisis and

the Carazo Administration

- The Palo Verde Controversy

- The Monge Administration

Chapter 7: Restructuring and Decentralizing

Conservation

PART II: Building a Green Republic

Chapter 8: Environmental Education:

Framework for the Future -... 329

- "Environmentalizing" the Public

- From National Parks to

National Environmental Ethic

Chapter 9: The Non-Governmental Approach -..-. 353

- The Active Role of NGO's

- Campesino and Indigenous

Movements

Chapter 10: iOro Verde!: Ecotourism for Economic Growth _..._. 385

Chapter 11: The National Biodiversity

Institute

Conclusion: "Picking up the Gauntlet" - 436

Endnotes - 447

Appendices - 508

Bibliography - 518 


\section{LIST OF FIGURES AND TABLES}

Introduction

Figure 1: The Republic of Costa Rica (map) _-_ 4 Chapter 2

Figure 1: Costa Rican Deforestation over Time -_-_-_-_- 52

Chapter 3

Figure 1: National Parks and Equivalent Reserves (map) --- 75

Table 1: Protected Areas of Costa Rica _-_._._._._. 76

Figure 2: La Casona at Santa Rosa National Park -......- 100

Figure 3: Pres. José Figueres Ferrer _- 117

Chapter 5

Figure 1: Pres. Daniel Oduber Quirós

Chapter 6

Figure 1: Pres. Rodrigo Carazo Odio _- 188

Figure 2: Pres. Monge's "Back to the Land" Campaign -...-- 259

Figure 3: Political Cartoon, Santa Rosa secret Airstrip -- 266

Chapter 7

Figure 1: Original Extent of the Pacific Dry Forest ----- 272

Figure 2: Costa Rican System of Conservation Areas (map) - 316

\section{Chapter 9}

Figure 1: Costa Rican Indigenous Reserves (map) -

Chapter 10

Figure 1: Principal Nature Tourism Sites in Costa Rica --- 400

Table 1: Costa Rican vs. Foreign National Park Visits --- 404

Table 2: Costa Rican vs. Foreign Visits, Selected Parks - 405

Table 3: Arrival Statistics, International Travellers --- 407

Figure 2: Parismina Lodge near Tortuguero National Park -- 420

\section{Chapter 11}

Figure 1: INBio Biodiversity Stations (map) -

Figure 2: INBio Collections Operations (flow-chart) -- - 428

Figure 3: An Early INBio Operating Budget -

Figure 4: INBio Network of External Relations - 


\section{INTRODUCTION: The Costa Rican Uniqueness Factor}

Costa Rica is.. . something of a model in Latin America. The enormous ecological variety encompassed in such a small area makes the country a tropical laboratory.

The first thing to understand about Costa Rica's environmental history is how the country is so specifically different in many ways from the rest of the world. A preliminary glance reveals that Costa Rica is one of the least impoverished countries in the Third World, has the highest per capita income in Central America, maintains one of the highest literacy rates in the world (ninety-eight percent, according to some accounts), and leads Cen2 tral America in elementary and higher education. Likewise with the possible exception of Cuba, Costa Rica enjoys the best federal health care coverage in the western Hemisphere and has one of the highest life expectancy ages (seventy-four years) and one of the lowest infant mortality rates in Latin America.

Remarkably, Costa Rica has no military.* Abolished in 1948 under the reform platforms of José Figueres, the government converted army fortresses into museums and freed federal funds for

* Costa Rica does, however, maintain active national police units (the Civil and Rural Guards) and nine government agencies control their own security forces. Some units receive military training, but there is no central command structure to enable them to assert undue influence over civilian society, as is frequently the case elsewhere in Latin America. Moreover, the head of the units is appointed by each new president every four years (with constitutionally-prohibited re-elections), further precluding the chance for military caudillos to establish a power base. 
other endeavors--a stand which has been warmly supported by the people of Costa Rica. Echoing the sentiment of many who call Costa Rica the "Switzerland of Central America," Gabriel Ureña has suggested that militarism ("that political plague of other countries in Latin America") could not prosper here where "law, peace, and a respect for human dignity are sacred precepts." Pertinent to this work, of course, is the fact that costa Rica has developed one of the most complex systems of protecting natural areas in all of Latin America. And protecting wildlands means protecting species which Costa Rica has in incredible abundance. Flying, roaming, or swimming through the country are 850 species of birds, 220 species of reptiles, 160 species of amphibians, 280 species of mammals (almost half of which are different species of bats), and 130 species of fresh water fishes. Even more impressive is the diversity within the plant kingdom. There are approximately 9,000 species of vascular plants (four percent of the world's total) of which 1,200 are different species of orchids and 1,200 are different species of hardwood trees. In some places the trees grow at a density of 200 or more species 5 per acre. The number of insect species is another story. Already numbered in the tens of thousands, research entomologists continue to discover thousands of previously unidentified species from the tree canopies of Costa Rica's many tropical forests.*

* The National Biodiversity Institute (see Chapter 11) is working to inventory Costa Rica's biological species. Insect collectors were bringing in some 100,000 specimens a month in 1990 when the director asked that they try to restrain themselves! 
What makes this biological information of such interest is that the high speciation occurs in so small an area. Costa Rica, a country of only 19,600 square miles (just smaller than west Virginia), is only 250 miles long and 150 miles wide at its widest point (see map, Figure 1). Yet the number of plant and animal species there is greater than that of the United States and Canada combined.

Costa Rica's phenomenon in biodiversity can be explained in large part by the country's unique geological history. Formed during the Pliocene (only three to four million years ago), an uplift united a small archipelago to become a land bridge between North and South America. Costa Rica is located in the middle of this region which geographer Carolyn Hall refers to as the only place in the world that is "both interoceanic and intercontinen7

tal." Noted Swiss biologist Henri Pittier, who studied and worked in Costa Rica in the late nineteenth and early twentieth centuries, was one of the first scientists to discern that such a meeting point allowed the free transfer of species from north to south. The transcontinental meeting point, then, greatly enriched the flora and fauna of the isthmus, an accepted theory referred to by another scientist as being that of a "biological bridge [and] filter."

But the abrupt variations in topography and climate played an even greater role in species diversification in Costa Rica. What Hall has called a "great complexity of surface land forms" includes three distinct mountain ranges (the Central, Guanacaste, 
Figure 1: The Republic of Costa Rica

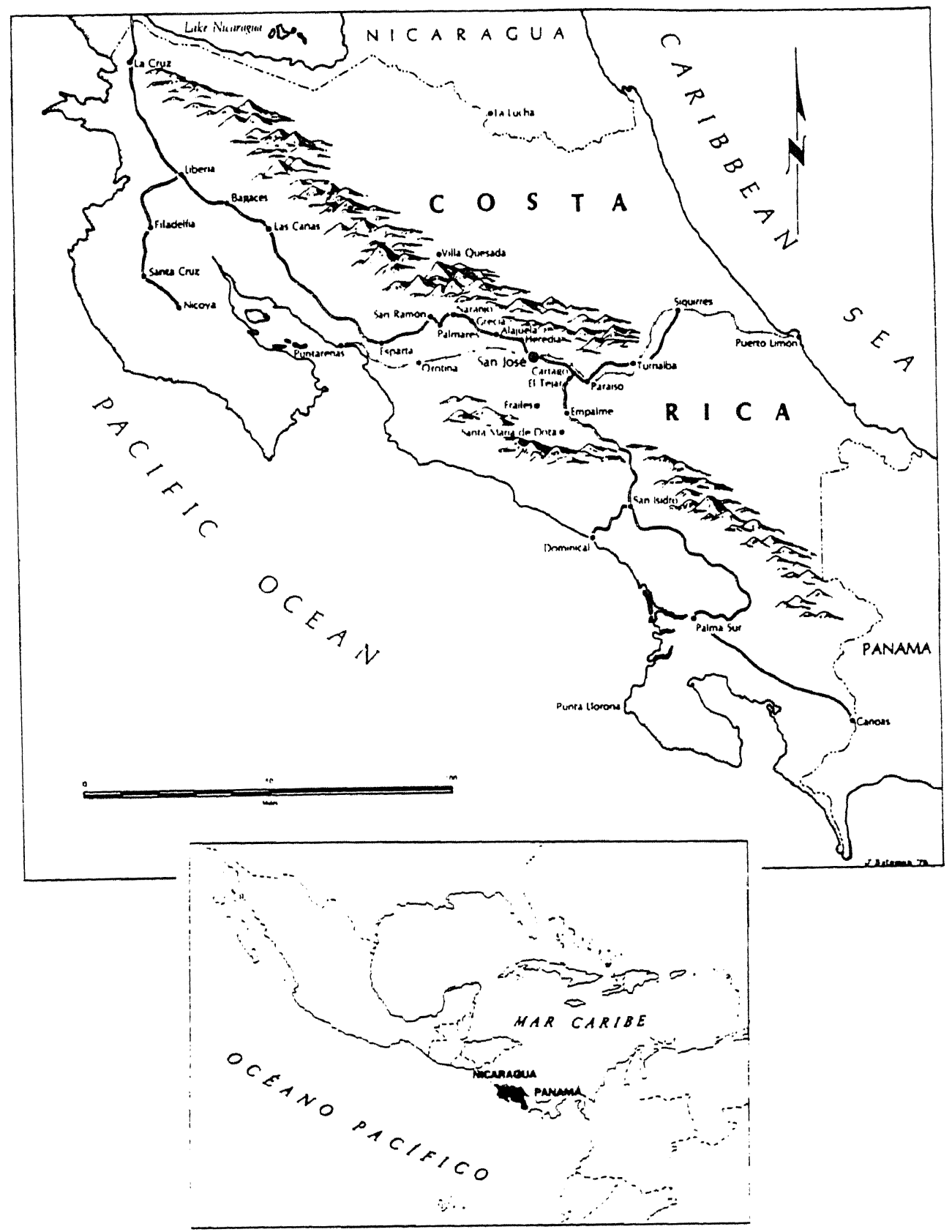


and Talamanca cordilleras) which climb up to 6,000 feet elevation, and five major natural areas.* Hall explains that the different "microclimates" that developed in each region produced "an ecological diversity peculiar to the world's tropical, mountainous regions" where elevation bears greater responsibility than latitude for "rapid and qualitatively different environmental changes. . . ."

Leslie $\mathrm{R}$. Holdridge, an internationally respected forestry biologist who spent much of his adult life in Costa Rica, developed in the $1960 \mathrm{~s}$ and $70 \mathrm{~s}$ a bioclimatic classification system of life zone ecologies for his adopted country. He identified twelve distinct life zones in Costa Rica (i.e. tropical dry forest, montane wet forest, etc.) based on temperature, rainfall, evaporation, humidity, and elevation. That these different life zones occur in such close proximity to each other in such a small area creates what has been termed a "biogeographical combination" or a "complex ecological mosaic" of species diversification. In evolutionary terms, a "riot of adaptations" occurred as plants and animals specialized to fit into such complex environments. The history of another species in Costa Rica, Homo sapiens, has also been shaped by the unique biogeography of the area. Dense tropical forests and steep mountainous terrain prevented a large pre-Columbian indigenous population to thrive in the area that is today Costa Rica. The exact number of native people who

* They are: Central Valley, Northern wet Caribbean, Dry Pacific, Southern wet Pacific, and Southern wet Caribbean regions. (10) 
lived there prior to the European encounter is a topic of considerable academic contention. Estimates ranging from 27,000 to 400,000 are debated by anthropologists and historians, but one of the most respected authorities on the subject argues that an approximate figure of 80,000 reflects the most realistic pre12

colonial population. Whichever figure is correct, these native people were also a result of the isthmian land bridge--"descendants of the Meso-American and South American cultures who maintained intercultural contact. . . " according to anthropologist Luis Tenorio. And scholars tend to agree that the population was sustainable to their tropical environment. The native population today is around 36,500--far less than in other parts of Central America--but the Indians share the country with approximately 13

3,000,000 other residents. (Indigenous issues in Costa Rica's conservation history as well as current concerns are discussed in Chapter Nine.)

Spaniards in the sixteenth century were not all that impressed with Costa Rica. Christopher Columbus may have thought the coastal areas scenically beautiful and held high hopes that riches there were awaiting his arrival (hence his naming the area "Costa Rica"--Rich Coast), but gold and other minerals were not to be found in significant quantities and the humid, thickly forested terrain did not seem hospitable to early explorers and settlers coming from Spain's more temperate and dry regions like Castile and Extremadura. Hence, during the colonial era Costa Rica evolved quite differently than many other areas of 
the Spanish world. Far away, and not easily accessible from the audiencia (provincial) capital at Guatemala City, Costa Rica had little early agricultural development and therefore European settlement made less impact on the natural environment. Jean Carriere suggests that "because Costa Rica was a relatively poor, isolated and thinly populated corner of the Spanish Empire, the loss of forest cover associated with European settlement was limited." Carolyn Hall points out that only a few thousand Spaniards ever settled in Costa Rica between 1502 and 1821 but that the "poorest Spanish colony became the most prosperous re14

public." Again this unique feature of Costa Rica's past was largely due to its environment.

By the 1830s Costa Ricans discovered that the soil and climate of the volcanic montane region of Costa Rica's central valley was ideally suited for the production of coffee. At the same time in history there was a growing world demand for the beverage which seemed to stimulate workers in industrial occupations. Hence, through the efforts of an English merchant named William LeLecheur (who introduced Costa Rican coffee to Great Britain in 1843), a strong European market became well established for the new commodity. But coffee in Costa Rica is a unique example of how a developing agricultural product did not necessarily impair the environmental well-being of the countryside. While Carriere has referred to the coffee industry as Costa Rica's "first wave of deforestation," he also shows how most of the country remained 15

under forest cover until the 1950s. Another study credits Costa 
Rica's "coffee monoculture" as being

a rare exception to the general rule of monocultures producing a dependent, stale economy and subsequent underdevelopment. Coffee cultivation in mid-1800s Costa Rica established a social climate that encouraged strong development of natural sciences. (16)

Costa Rica accomplished such a feat by opening up trade patterns with a previously closed European market.* This provided the stimulus for scientists to travel to Costa Rica to study its unique geography and later to instruct Costa Ricans about the more scientific end of their natural resources.

Equally important is the fact that most Costa Rican coffee growers farmed on small, family-owned cafeteras and were comparatively responsible land stewards as opposed to the elite landholders who practiced large-scale plantation monoculture (the latifundista experience typical in much of the rest of Latin America). Early twentieth-century tropical researchers Amelia and Philip Calvert observed that "the number of small landowners and coffee growers in Costa Rica is very great"--a "great advantage.. . in contrast with the conditions prevailing in the larger countries of that part of the world." They went on to explain that where many own small pieces of ground, a much greater . . interest in the prosperous development of community and of peaceful progress exists than where there are only a few great landowners and the great mass of the population, having nothing to lose, are more indifferent and more easily drawn in the wake of political adventures. (17)

\footnotetext{
* International markets had been officially closed to Spanish overseas territories during the colonial era due to spain's mandate for colonies to trade solely with the mother nation.
} 
A middle class thus emerged that not only valued the land but established the base for a stable democracy that would force 18

fewer pressures upon the natural environment.

As Hall has suggested, Costa Rican agriculturalists soon discovered that their country's "large number of life zones permit[ted] the cultivation of a much wider range of crops than would otherwise be possible at this lattitude." Bananas, Costa Rica's next agricultural boom, and other crops of the twentieth century, however, were not as friendly to the environment. But a basis was established for creating an environmental awareness by the very geographic make-up of the country. A cyclical pattern evolved: the geography which made costa Rica unique led at first to the development of a different kind of agricultural society-one based on relatively small landholdings. Eventually, as agricultural conditions and international markets dictated, more and more forested land was turned into croplands, plantations, and pastures. This dangerous exploitation of natural resources, however, aroused a dormant ecological conscience in many Costa Ricans to address the need to protect what remained of the nation's natural heritage. Problems and solutions of this environmental model are examined below, but whether via its cultivated lands or its conservation areas, Costa Rica remains today a green republic--a country lush in tropical verdure and well-established in environmental policy-making. 
PART I:

COSTA RICA'S

HISTORY OF CONSERVATION 


\section{CHAPTER 1}

\section{A LEGACY OF SCIENTIFIC THOUGHT AND TROPICAL RESEARCH}

To those who with effort, caring and dedication from 1841 to 1941 established the basis for biological sciences in our homeland. May their labor be a permanent example for future generations. -plaque at entrance of the University of Costa Rica's School of Biology

Listed with the above message are the names of twenty-three professional biologists (some foreign and some Costa Rican) who have played a profound role in the conservation history of Costa Rica. Part of Costa Rica's uniqueness has been its historic ability to lure a significant number of foreign scientists and to establish a sound training system for local scientists to study and understand the nation's diverse natural history. Mario Boza, one of Costa Rica's leading conservationists, explained that "the diversity and wealth of Costa Rica's flora and fauna, as well as the majesty of its countryside, have attracted the attention of scientists and naturalists from all over the world since the mid1 1800s." The legacy of scientific investigation--indeed the drive to understand Costa Rica's biological uniqueness--became an important seed for the development of a national conservation ethic and thus to an appreciation for conserving natural resources. Costa Rican biologist Luis Fournier acknowledged these links when he wrote that "Costa Rican ecological thought developed from the numerous observations about the country's natural history in the past century and early decades of this century by foreign and national naturalists." 
Tracing the history of interest in Costa Rican ecology and conservation goes back to the sixteenth century. Fernández de Oviedo (a Spanish naturalist who travelled to colonial Costa Rica in the 1700s) was one of the first to recognize the area's distinct biodiversity and warned against deforestation. But while there were other early decrees and proclamations for forest preservation and soil conservation in 1770 s and 1830s, there was not a base of support for conservation issues in Costa Rica until the final decades of the nineteenth century.

Largely ignored by the colonial government, Costa Rica by the time of independence was one of the poorest and least developed areas of the United Provinces of Central America. After separating from the federation, Costa Rica never had the wherewithal nor the population to support higher education. There was virtually no national scientific or professional training. Charles Stansifer shows that by 1845 Costa Rica had no bookstores, hospitals, universities (elementary education was only marginal), research or scientific organizations, or even theatres. He goes on to say that the few scientifically trained persons in Costa Rica at this time were either Guatemalans, Nicaraguans, or Costa Ricans who had studied at foreign schools. A study by Luis Gómez and Jay Savage claims that European naturalists were at first more interested in studying the more geologically wealthy regions of Mexico and Peru because of world fascination with gold and silver. Clearly, Costa Rica's early national years were characterized by what costa Rican noted biologist Rafael Lucas Rodríguez 
has called a "slow development of modest and utilitarian under3

standing of Nature."

Two events outside of Costa Rica, however, reversed forever the scientific community's disinterest in Costa Rica's tropical ecology: international demand for coffee and speculation for a trans-isthmus canal in lower Central America. Part of coffee's role in Costa Rican conservation history has already been mentioned. Not only did the railroads, built to transport coffee beans to port, open up many unexplored areas of the country, but the coffee trade with Europe brought many foreigners to Costa Rica. Some were scientists who because of socio-political repression and scientific stagnation in their home countries were excited by the prospect of marketing their services in a new area and by the adventure of visiting a poorly understood biological region. One German scientist who visited Costa Rica in the early 1850 s explained that Germany in the mid-nineteenth century was divided into competitive regional states which were governed by "reactionary police regime[s]." Thus for many professional researchers, the Americas "seemed like the place to go." Schools and fine arts developed more quickly with the advent of foreigners, triggering more communication and travel between Europe and Costa Rica. News of the country's vast diversity sparked interest for European naturalists to visit and "those who came usually stayed."

Towards the end of the nineteenth century when a growing commercial interest emerged for constructing a Central American can- 
al to connect the Altantic with the Pacific, attention focused on Nicaragua, Costa Rica, and the Colombian province of Panama. Scientists were drawn to the region to investigate canal site possibilities. Two German naturalists, Moritz Wagner and Karl Scherzer, became enchanted with Costa Rica and stayed to research its natural history. According to one historian of the subject, their writings (especially Die Republik Costa Rica) "probably did more to draw European scientists [to Costa Rica] than any other work."

One such scientist who followed was the Danish botanist Anders Sandre Dersted who was the first to publish a detailed description of Costa Rican plants. Others were William More Gabb (from Great Britain) who studied Costa Rican geology, paleontology, and zoology; and Joseph Warscewicz (from Lithuania) who studied horticulture and ornithology and was the first to send diverse bird collections to the most respected natural history museums of the time in Berlin and London. In the $1880 \mathrm{~s} F$. Duncane Godman and Osbert Salvin studied in Costa Rica and published their Biologia Centrali-Americana, one of the most complete biological works about the region up to that date. The German geologist and naturalist Karl Sapper also conducted investigations in Costa Rica, and the American ornithologist George N. Lawrence was the first to catalogue Costa Rican birds, listing 511 species-two-thirds of all Costa Rican bird species known today. The research of these scientists inspired even greater interest in Costa Rica abroad. 
Two other German scholars who went to Costa Rica in the mid1800 s were more influential in the legacy of tropical research. Alexander von Frantzius and Carl Hoffman, both medical doctors, landed in Costa Rica somewhat by chance. Von Frantzius was advised to move to the tropics to improve his health and Hoffman was intrigued by the adventures of exploring mountains. They both practiced medicine in Costa Rica and in spare time climbed Poas and Irazu volcanoes--coming to know the ecologies of both mountains intimately and producing major collections of their flora and fauna. Historian Carlos Meléndez claims that these two German scientists "converted our country. . . initiating a prodigious era for [the study of] our science."

Alexander von Frantzius was the first scientist to catalogue Costa Rican mammals. He also wrote extensively on the native tropical plant life and through his botanical explorations and publications "made Costa Rica known to the scholarly world." He also produced the first academic work on Costa Rican climatology. Carl Hoffman, although far less published than von Frantzius (he only published three important articles on volcanoes), did become known for his taxonomy of Costa Rican plant and animal species (of which twelve bear his name today) and also sent impressive collections to Berlin.*

* Hoffman served as an army surgeon for the Costa Rican forces in the battle against American filibuster William Walker in 1856. While in Guanacaste Province (northwest Costa Rica) he noted the unusual diversity of bats which he collected and studied. His work in this area became the first scientific research of bats in Costa Rica. 
room of which was used as a laboratory and meeting place for students. Three such Costa Rican students, José Zeledón, Anastasio Alfaro, and J.F. Tristán (known as the "drugstore gang"), became close assistants, accomplished biologists, and early leaders in the effort to research tropical issues and educate others.

An important step in Costa Rica's favor and a move that was unwittingly conservationist, was the government's spirited attempt in the mid-1800s to improve the educational system. The University of Santo Tomás was founded in 1844 as a way to attract scholars and educate professionals. But lacking enough local teachers and scientists, the government decided to recruit Europe8 an educators to teach Costa Ricans. The administrations of Jesus Jimenez and Tomás Guardia in the 1860 s and 70 s invited many German and Swiss teachers. Many foreigners who came, however, left after short stays when they discovered that they were expected to spend more time teaching than doing research. One who stayed was Helmuth Polakowski, who became an expert in tropical botany The University of Santo Tomás was abolished in 1888 by President Bernardo Soto. His influential and politically powerful minister of public instruction Mauro Fernández believed that no university could succeed without a strong secondary school system in place. He was actively involved in starting the challenging school, Liceo de Costa Rica, changing education to be sponsored by the state instead of by the church, enacting legislation to make education compulsory to the seventh grade, opening up high schools to women, and beginning an even stronger push to attract 
foreign teachers. Several more Swiss scholars accepted the challenge. One, Henri Pittier, was another individual who was destined to change the course of the country's biological thought and to begin what has been called the "golden age of Costa Rican natural history." 9

Described as "determined, indefatigable and tyrranical," Henri Pittier had a bold "multidisciplinary approach to field biology." To acquaint himself seriously with the country, he climbed every volcano more than once, lived with different indigenous peoples, and collected as many specimens as he could to "amass a body of information unsurpassed to that date." He was intrigued and captivated by Costa Rica's biodiversity, calling the country the "botanical and zoological emporium of the 10 continent."

Pittier branched out from the confines of his own research to organize the National Agricultural Society and to create the National observatory. He also recruited many other scientists to study in Costa Rica and with their help developed the largest herbarium in Latin America at the time. More importantly, he founded and succeeded in acquiring government funding for the Physical Geographic Institute (IFG--called the National Geographic Institute after 1914). This institute, soon to become one of the leaders of its kind in Latin America, was in charge of collecting biological data, managing the herbarium, recording all meteorological information, researching national agricultural problems, and perhaps most importantly, accurately mapping the 
republic. All of these successes, unheard of in much of the rest of Latin America, created a national base to encourage scientific thought and to spur others to pursue research topics in Costa Ri11

can natural history.

Disagreeing with the government's 1904 decision to place the IFG under the auspices of the National Museum, Pittier moved to the United States and accepted employment with the U.S. Department of Agriculture. Capable scientists like Adolphe Tonduz, Carlos Wirkle, and George Cherrie carried on Pittier's work in Costa Rica, and Anastacio Alfaro (one of von Frantzius' "drugstore gang") became the director of the museum and the IFG. By the time Pittier left Costa Rica, "sciences from anthropology to lim12 nology flourished."

The National Museum, then, became the focus for scientific research. Alfaro (only twenty-two years old at the time he was appointed director) had the able help of José Zeledón. Zeledón was sent to study at the Smithsonian Institution in Washington, D.C., and established important liasons with American scientists. With these connections, the floodgates were now open for U.S. researchers to start pouring into Costa Rica--a flow that never waned. Some of these biologists included Edward Cope and Edward Taylor in herpetology, and Philip and Amelia Calvert in entomology. The Calverts, who were primarily interested in studying the life histories of tropical dragonflies, travelled around Costa Rica for a year (May 1909 to May 1910) and ended up writing a comprehensive field biology study entitled A Year of Costa Rican Nat- 
ural History. Concerned about what "transformations" in the land would occur in Costa Rica due to the Panama Canal (influx of people, more transportation, etc.), the calverts wrote that the book's mission was to "leave for the future a picture of what the past contained." To do so, they studied with (and received valuable local assistance from) such scientists as Adolphe Tonduz, Henri Pittier, J.F. Tristán, C.H. Lankester, and José Zeledón and acknowledged the "liberal and enlightened Costa Rican government" for its recognition of the importance of studying tropical sciences. The government's attitude coupled with Costa Rica's "high mountains, rushing rivers, . . great variety of climate and of natural products," they wrote, made "such wonderful inducements 13

for naturalists and entomologists." Swiss biologist Paul Biolley also made important contributions in entomology and malacology in these years. By 1914 Costa Rica had become the center of scientific research in tropical America.

Attracted to such a place in the 1930 s was American botanist (and later ornithologist) Alexander Skutch. Skutch arrived in Costa Rica to extend his dissertation research on the leaves of banana plants but ended up staying for the next forty years. In that time he homesteaded a small farm in the Valley of El General, meticulously studied the life histories of a variety of tropical birds, and did research on many different plants. His work resulted in over 200 journal articles and a dozen books on topics ranging from ornithology and botany to tropical conservation and philosophy. Summing up why he and many others in his field were 
so enchanted with Costa Rica and why he stayed for so many years,

Skutch wrote that

in the mid-1930s, Costa Rica was still largely unspoiled. Its population of less than a half a million people. . . was concentrated in the narrow Meseta Central. . . Other advantages. . . to the naturalist were its political stability and the friendliness of its people. . . . Costa Rica has a record of continuous, orderly constitutional government that scarcely any other country in Latin America can match. Thus the naturalist working in some remote spot was not likely to have his studies suddenly interrupted or his thin lines of communication cut by a violent upheaval, as has happened to many in Latin America. . . (14)

Without a university of even an agricultural school (until

1926) to support professional research efforts, however, the

period from the 1920 s to the 1950 s witnessed a decline in Costa

Rican scientific study. Because field research was viewed by many as a "pastime for the eccentric or the wealthy," few Costa 15

Ricans became involved. An attempt in the 1920 s to reopen a university hindered rather than helped these efforts because of a lack of trained faculty in the biological sciences. When the University of Costa Rica finally was established in the 1940 s the National Museum was placed under its direction, managed poorly, and many of the specimen collections of earlier scientists were ruined.

Despite these setbacks, progress occurred with the establishment of the National School of Agriculture in 1926. Staffed with people like José Orozco (a sylviculturist who urged forest protection), José Arias (who developed an early conservation plan), and Rafael Chavarría (a conservationist-minded director) this school became instrumental in teaching farmers proper use of controlled 
burning, how to avoid erosion, and other soil conservation techniques. Luis Fournier writes that the School of Agriculture went on to play "a great role in helping form conservationist thought." One instructor there, Enrique Jiménez (educated in Belgium), taught with a "conscience for environmental problems," later became Costa Rica's Secretary of Agriculture, and was instrumental in the passage of the Ley de Quemas (a law regulating 16

controlled burns) to protect the forests.

Progress also occurred in the 1930 s and 40 s through the work of an exceptionally bright Costa Rican scientist named Clodomiro Picado Twight. Educated at the Sorbonne, Picado returned to his homeland to concentrate on the study of Costa Rican natural resources. He published hundred of scientific articles, pioneered research on bromeliads, and wrote The Poisonous Snakes of Costa Rica. He has been called the "first Costa Rican academic biologist." Unfortunately Picado died at an early age in 1944 and never lived to be a part of the University of Costa Rica (UCR). His statue, however, graces the front lawn of the School of Biology at UCR as an inspiration to future biologists.

But while Clodomiro Picado conducted independent research, and efforts of the National School of Agriculture centered primarily on conservationist farming practices, there still lacked a professional outlet for scientific study and a center to train others in tropical research. This changed in the 1950 s via the expansion of the University of Costa Rica. In the early fifties Antonio Balli (an Italian biologist) and Rafael Lucas Rodríguez 
Caballero (a Costa Rican educated at the University of California) organized the biology department at UCR. Rodríguez, whom Luis Fournier has called a man with "great vision for the future," published a forward-looking work on areas in Costa Rica 18 that he believed required protection. He was also instrumental in working to have the biology department changed to become the School of Biology, a separate division at the university, in 1955. A full-time staff of professional biologists was hired and Archie F. Carr, a herpetologist at the University of Florida, designed the curriculum. Carr spent years studying and lobbying for the protection of the green sea turtle (Chelonia mydas) that oviposits on Costa Rica's northeast coast. The School of Biology became one of the best of its kind in Central America and has served as a sprinboard for research into tropical studies for costa Rican and other Latin American students. It was dedicated to Dr. Rodríguez in 1979. A national wildlife refuge, established in Guanacaste Province in 1977, also bears his name.

Another influential faculty member of the UCR's School of Biology was Alexander Skutch who taught there for many years. Increasingly over time, Skutch's beliefs in natural history and ecological harmony evolved into conservation advocacy. He decried how man "covers larger areas with his highways and constructions, destroys thriving forests to make cultivated fields and pastures for his beef cattle, contributes to the spread of deserts by overexploiting arid lands, and poisons seas with his wastes." For Skutch, the study of natural history, tropical ecology, and con- 
servation complemented his beliefs in ajimsa yoga regarding the sanctity of all life and for the preservation of a harmonious balance of nature. According to fellow biologist and environmentalist Luis Fournier, this "very special philosophy toward nature, of great significance from a conservationist point of view, without doubt influenced [the conservation] movement in costa Rica." The University of Costa Rica is important in Costa Rica's conservation history in other ways also. The National School of Agriculture (changed to be called the School of Agronomy) became a division of UCR and continued its instruction of conservation values. The Costa Rican zoologist Alvaro wille (educated at the University of Kansas) developed the entomology section there Iikewise has become a valued, regional center for tropical is21 sues. UCR's law school also became actively involved in environmental policy via its Center for the study of National Problems.

The momentum continued with the development of organizations promoting conservation issues in Costa Rica. In 1942 the InterAmerican Institute for Agricultural Sciences (IICA) was founded in Turrialba by the Organization of American States (OAS). It specialized in training individuals in agricultural sciences, forest conservation, and wildlife management. In 1972 the institute's board members voted to end affiliation with the OAS and to form an independent research and training organization with the new name CATIE--Centro Agronómico Tropical de Investigación y Enseñanza (Tropical Agronomical Research and Higher Education center). It is headquartered in a beautiful campus-like facility 
with modern laboratories, classrooms, and library just outside of the city of Turrialba. CATIE has sponsored a wide variety of tropical agricultural programs over the years and has attracted a great number of national and international scientists and students to study sustainable tropical agronomy and forestry.

Dr. Leslie Holdridge (engineer of the bioclimatic system to classify life zone ecologies) was one of the early and most instrumental leaders at CATIE, and was an instructor there for many years. He believed in rainforest preservation and later purchased a heavily forested tract of land in the north central part of the country ("La Selva") that he used for more intensive study of tropical lowland systems. Moving to CATIE in 1952 to study under Holdridge's direction an to earn his Masters in Science was a Venezuelan graduate student named Gerardo Budowski. Budowski, who went on to Yale University to pursue a doctorate in forestry (his dissertation dealt with tropical forest succession based largely on his research at (ATIE), has used his knowledge of tropical ecosystems to promote conservation both in his adopted country of Costa Rica and in a variety of positions abroad. He went on to become a CATIE instructor and later its Director General, a scientist at UNESCO in Paris (where he organized the 1968 world Biosphere Conference), and for six years was the Director General of the International Union for the Conservation of Nature (IUCN) in Switzerland. He is currently on the international board of trustees of the World Wildlife Fund, president of the World Ecotourism Society, Director of Natural Resources at the University 
for Peace in Costa Rica, and still maintains ties with his "beloved" CATIE as Senior Advisor to the Director General.

In 1966 CATIE initiated a course on national parks and wildIife under the direction of Dr. Kenton Miller (a biologist from the United States) who likewise came to appreciate very deeply Costa Rica's tropical environment and potential for conservation. He taught there for several years and later became an inter23 national authority on national park development. One of his CATIE students in the late 1960 s was a Costa Rican named Mario Boza who went on to spearhead the country's national park program. Boza had recently graduated from UCR with a degree in agronomy and had wanted to study teak wood production at CATIE. Heeding the advice of his instructor Gerardo Budowksi, however, he got involved with Kenton Miller's national parks course, wrote a Master's thesis on the development and management of a national park at Poás Volcano, and has been in the forefront of Costa Rica's conservation program ever since. He went on to become the nation's first director of its fledgling national park service, natural resources advisor to President Rodrigo Carazo, university professor, founder and director of the conservation organization Fundación de Parques Nacionales, author of several books on Costa Rican national parks, assistant director of the Ministry of Natural Resources, and currently is in charge of the Caribbean Conservation Corporation's Paseo Pantera project to link conserva24

tion areas throughout Central America.

Through people like Leslie Holdridge, Gerardo Budowski, and 
Mario Boza, CATIE has actively influenced the scientific and conservation leadership of Costa Rica for over five decades and has had an impact on conservation in other tropical countries. In 1982 Craid MCFarland, CATIE's director of the Wildlife and Watershed Program, conducted a survey to inventory the conservation strategies of other Third World nations (i.e. national parks, provincial or state parks, national forests, biological reserves, watershed conservation, management plans, legislation, finances, etc.) to serve as a base data pool to improve CATIE's ability to 25 understand the conservation needs in other nations. Likewise, the center continues to attract many foreign students each year. There have been other private sources of conservation in Costa Rica that have played large roles in the country's legacy of scientific thought. In the early 1950 s American Quakers from Alabama, fleeing a militarisitic U.S. government involved with the Korean conflict, were attracted to Costa Rica because of its abolition of the army and looked for a place to settle. They chose an area near Monteverde in north central Costa Rica to practice low technology agriculture and dairy farming. Much of the surrounding area had been deforested by local farmers, but the Quakers, under the leadership of Wilford Guindon, recognized the need to preserve forests on the mountainsides to protect the important watersheds in their region. To that end they established an 800 acre reserve in a pristine montane environment that abutted their farms. Today the area is part of the Monteverde Cloud Forest Preserve which protects habitat for many endangered spe- 
cies, especially well known of which is the resplendent quetzal (Pharomacro mocino).

In 1959 Archie Carr founded the Brotherhood of the Green Turtle and its subsidiary the Caribbean Conservation Corporation (CCC)--the first non-governmental conservation organization in Costa Rica. Because of uncontrolled commercial turtle and turtle egg hunting, numbers of the giant reptiles had dropped to dangerously low levels and were threatened with extinction. Carr understood the urgency of the situation and the CCC set out to research the ecology of the turtle and to advocate protection of its most important nesting habitat at Tortuguero (meaning literalIy "place of the turtle") on Costa Rica's northern Caribbean coast. The organization's work culminated with the establishment of a protected area for turtles in 1970 and when it was enlarged into a national park (with carefully monitored visitation policies) in 1975. It continues to research, track, and count green turtle populations and has branched out into other regional conservation campaigns.

Dr. Carr's sons, Archie III and David--both of whom have spent considerable time conducting research on tropical conservation in Costa Rica--are now the helm of the CCC. They, along with Mario Boza and James Barborak (a U.S. biologist who started coming to costa Rica in the 1970 s as a conservation consultant for the National Park Service), are leading the efforts of the Paseo Pantera project. A joint effort with Wildlife Conservation International (a division of the New York Zoological Society), 
the CCC's objective is to halt the fragmentation of biologically diverse habitats ranging from southern Mexico to Panama. Working to connect conservation areas with ecosystem corridors, however, also provides protection for important watersheds in the region-vital sources for water and flood control for thousands of cen26

tral Americans.

Another organization called the Tropical Science Center (TSC) also has played an active role in Costa Rican conservation. TSC is a private consulting firm that was established in 1962 by three American biologists--Leslie Holdride (the internationally known tropical forestry scientist), Robert Hunter (a forester and land-use specialist), and Joseph Tosi (an agricultural scientist). The TSC has assisted the IICA (CATIE) with many projects, developed a biological station at Rincón de Osa, organized conferences and training sessions, and worked for the creation of private biological reserves for field research and education.

The TSC has left its largest mark in Costa Rican conservation history through its efforts to preserve the Monteverde cloud Forest Preserve. The TSC's connection to the Quakers'watershed conservation program stems from the work in the early 1970 s of an ornithology graduate student from the United States named George Powell and his scientist wife Harriet Powell. According to Joseph Tosi, the Powells were conducting dissertation research on birds of the Tilarán Mountains where they were "astounded" by the "extraordinary biological richness of the cloud forest" and "alarmed" by the threat posed to the area by hunters, land spec- 
ulators, and squatters. In 1972 George Powell approached the TSC for advice on establishing a non-profit association to enable him to apply for and receive grants for purchasing and protecting the area. "We were immediately interested," Dr. Tosi explains, and after visits with Powell to the area "we were in agreement that the area warranted full protection." Over the next few years Powell and the TSC set up the fund, received hundreds of thousands of dollars from international conservation organizations to acquire the land, and expanded the area into a 10,000 acre preserve. The TSC became its managing agent and Powell served several years as its director. The objectives of the preserve were to "protect and preserve the existing ecological communities in the area of the continental divide," to use the area for "nondestructive biological research," and to promote "environmental education, both formal and informal, through controlled visitation by the public."

Today the Monteverde Preserve is one of the best known parks in Costa Rica. With the help of the TSC and its offspring organization the Monteverde Conservation League (in Canada), the preserve is now over 27,000 acres and continues to expand. Expansion has meant that squatters who moved onto the land to farm in the 1970 s and 80 s had to move. The Monteverde Conservation League and the world wildlife Fund raised funds to help offset the cost of re-locating and re-settling them by "selling" tracts of land to donors for twenty-five dollars an acre.

In the early 1980 s a study group of the TSC created a recom- 
mendation for Costa Rica's National Park Service to develop the Tilarán Mountain area into a national park that would include the Monteverde Preserve. While this recommendation was denied in 1981 due to "a lack of money to pay the numerous occupants" and landholders in the region, it remains a private nature reserve 29

and open to the public. In 1995 over 50,000 people visited Monteverde despite the slow, rough mountain roads leading there. Plans to improve the roads were discussed but abandoned by the TSC as a measure to limit tourist access and prevent overburden on the fragile mountain environment. Dr. Tosi boasts that Monteverde remains today as "one of the most efficient, well organized, and exemplary private reserves of its kind in the world." Its relatively small area is home to more than 2,500 species of plants, 100 species of mammals, 120 species of reptiles and amphibians, 400 species of birds, and tens of thousands of insect 30 species.

A spin-off of the Monteverde conservation strategy occurred with the establishment of the Children's Rain Forest Preserve. Adjacent to Monteverde, this protected area is the result of a Swedish teacher's efforts to save unprotected areas surrounding the preserve that she observed were seriously threatened when she visited the site in the late 1980s. She returned to Sweden with these concerns and enlisted the help of her nine-year-old students. They started a fundraising drive to purchase (through the Monteverde Conservation League) thirty-five acres next to the preserve. The idea soon spread to other parts of Sweden and 
Europe, Great Britain, Canada, the United States, and Japan.

Through the efforts of school children across the world, then, more than 17,500 acres are now protected in the Children's Rain Forest Preserve and similar measures have started in other parts of the world. Joseph Franke has written that the program's success is "an example of how important conservation ideas often start small but have far-reaching effects."

By the early 1960 s research and instruction on tropical ecology was increasing in the United States. Six leading universities in this field (Michigan, Florida, Miami, Kansas, Harvard, and Washington) saw the need to consolidate efforts to develop a research field station in the tropics. Costa Rica was chosen as the site because of the number and proximity of its geographic zones, its broad biological diversity, and its politically stable government. In 1963 the consortium of these six schools plus the University of Costa Rica formed the Organization for Tropical Studies (OTS). Its mission was "to provide leadership in education, research, and the wise use of natural resources in the 32 tropics." According to one of its founders, Jay Savage of the University of Florida, the OTS was established "to develop a center for advanced graduate education in tropical sciences. . . [and] to develop a cadre of knowledgeable ecologists who had course and field experience in tropical environments."

The OTS has been accused of suffering from so-called "scientific imperialism" in its early years of existence. This "big stick" or "missionary" attitude was manifest in the fact that 
some U.S. and European scientists went to Costa Rica to show the locals what to do and how to perform research in their own country. Soon, however, OTS personnel learned to cooperate with the host government and have since included Costa Rican and other Latin American students and instructors in all research endeav34 ors. Over the years more than 700 papers have been generated by OTS research and many ecologists trained there have gone on to work for conservation issues or have become teachers themselves. Dr. Savage stated that "almost every major figure in tropical 35 biology today" has been associated with the OTS.

These oTS instructors and students have made a profound impact on the conservation history of Costa Rica and other tropical places. Early OTS directors who had an innovative environmental vision for tropical education were Norman Scott and Donald Stone. Daniel Janzen, one of the OTS's first students and who later taught there, moved to Costa Rica and has spent much of his life in researching and working to protect the tropical dry forest environment of Guanacaste. Another shining example of an OTS "product" is Rodrigo Gámez, a plant virologist, former molecular biology professor at UCR, and past natural resources advisor to President oscar Arias. Gámez, an OTS board member in the early $1990 \mathrm{~s}$ and currently director of Costa Rica's National Biodiversity Institute, stated that

my association with the OTS helped open my eyes to the importance of biological diversity, particularly for a country like costa Rica. From trying to figure out what all those gringos [were] doing down there, many costa Ricans have developed a 
greater appreciation of the nation's biological

wealth. The OTS has played a crucial role in

providing credibility for conservation. (36)

A big boost to the organization occurred in 1968 when Leslie Holdridge sold his property known as "La Selva" (the forest), an intact, relatively undisturbed lowland forest ecosystem, to the OTS. La Selva was an island in an area of increasing timber and cattle pressures, and, as Dr. Savage pointed out, Holdridge's "foresight in preserving a sample of undisturbed forest cannot be overstated." Located near Puerto Viejo in northeastern Costa Rica, La Selva became the oTS's biological station and center of tropical research. While only four and a half square miles in size, La Selva has half as many species as all of California, including 320 species of trees, 394 species of birds, 143 species of butterflies, 122 species of reptiles and amphibians, 104 species of mammals, and forty-two species of fishes. From this diversity, David Clark explains, "the varied and numerous investigations carried out at La Selva are an important reason why the tiny country of Costa Rica is one of the world's largest active research sites in tropical field biology."

In the 1980s La Selva was expanded to border Braulio Carrillo National Park (the combination of which has ben identified by UNESCO as a World Biosphere Reserve). The expansion ensured the seasonal migration of species within the different parts of the ecosystem--an activity that was being seriously threatened by increased logging and cattle grazing in the region. Along with international conservation and philanthropic organizations, the 
OTS actively participated in the campaign for the expansion, which resulted in the creation of a Zona Protectora (Protected Zone) by the Costa Rican government. Rodrigo Gámez stressed the importance of such a zone when he wrote that

The park and La Selva were linked by a narrow protected corridor for numerous species of birds, mammals, and insects and their periodic migrations between the highlands and the lowlands. Such action has received international recognition as one of the major recent accomplishments in biological conservation. We cannot put fences around the parks and reserves and forget about what happens outside them. (38)

The creation of the zona Protectora attracted even more local and international scientists to La Selva. Research usage increased fourfold, with the number of individual researchers there increasing by 257 percent in just six years. Laboratory and lodging facilities expanded, and by 1990 an average of twenty researchers a day were studying at La Selva. Fully one half of all OTS usage is by Costa Rican biologists and students and Costa Ri39 cans are on the staff of every oTs project. Likewise, the OTS has provided its services to its host country on many occasions. In 1983, for example, Charles Shnell (a Harvard biologist who worked in Costa Rica for twenty years and was oTs Vice President for Planning) sponsored an OTS biological inventorying project for the newly created Chirripó National Park.

Today OTS is a consortium of fifty-two U.S. and Costa Rican universities. The mutual advantage of it being located in Costa Rica are summed up by current oTs co-director David Clark:

The most important of OTS' experiences. . . is the long history of positive relations it has enjoyed 
with its host country, the Republic of Costa Rica. This special relationship affects research in innumerable ways, from the ease in which research permits can be obtained to the willingness of talented Costa Rican biologists to collaborate in joint projects. Costa Rica is unusually receptive to foreign scientists and the oTs has benefitted greatly from this attitude. For its part, Costa Rica has benefitted ecologically, educationally, and scientifically from the relationship.

One reason that all of these organizations and programs have been successful is due to Costa Rica's lack of an "anti-gringo" sentiment. Many scientists have felt that foreign biologists are generally considered for what they are--biologists and not gringos, and that most Costa Ricans support the need to conserve areas for future generations. Likewise, as alluded to above, CATIE, TSC, and OTS, while developed by Americans and other foreigners, have usually worked well with the government and included Costa Ricans in planning, advice, training, and employment.

Other important figures in Costa Rican conservation history appeared in the $1960 \mathrm{~s}$ and $70 \mathrm{~s}$. People like Luis Fournier, Sergio Salas, and R. Daubenmire (botanists who made important contributions to forest phenology), Gary Stiles and W.I. Ramírez (zoologists who specialized in ecology and reproduction of natural ecosystems), and Alexander Bonilla (UCR biologist and avid envirronmentalist) all represent part of the result of Costa Rica's scientific legacy. Others advocated conservation and changes in policies by becoming involved in government agencies. Biologists like Mario Boza, Rodrigo Zeledón, and Carlos Quesada (who developed guidelines on the rational use of the environment), Alvaro 
Ugalde (one of the first graduates of UCR's School of Biology, long-time advocate of conservation measures, and several times director of the National Park Service), Luis Diego Gómez (a botanist who helped revitalize the National Museum to regain its former status as a center to stimulate Costa Rican field biology), Rolando Mendoza (an avid national parks and protected areas proponent), and Tobías Meza Ocampo (a specialist in wildlife management) among many others are descendants of Costa Rica's emphasis on science who represent this group.

Much of these scientists' work was financed through CONICIT (Consejo Nacional de Investigaciones Científicas y Tecnologicas), which is similar to the National Science Foundation in the United States. Established by the government in 1973, CONICIT has assisted scientists by funding both large-scale programs (i.e. the national Plan de Desarrollo--a long-range research priority setting plan) and small-scale projects (i.e. plant pathology and species-specific population studies). The government's support of CONICIT is another reflection of how the nation's understanding of the importance of scientific inquiry.

While the percentage of Costa Ricans who are scientists is small (and of those, the percentage of field biologists even smaller--which is typical of most, if not all, countries of the world), interest is there, numbers are growing, and a strong educational system is in place to foster scientific thought and conservationist policies well into the future. The Gomez and Savage study concludes that 
Costa Rica now has a cadre of biologists whose orientations have been shaped by the new theoretical ecology, the ecological movement, and the stimulus of the OTS. Through their efforts, Costa Rica has a solid scientific base in its CONICIT, its universities, and the National Museum. It has an awareness of ecological problems and the proper attitude to face [its environmental] dilemma.

Daniel Janzen believes that this base will be needed because of "how scanty our knowledge [really] is regarding Costa Rican natural history." Believing that present research will soon be outdated, he views the need as great for future well-trained ecologists. Rodrigo Gámez agrees. He writes that

Costa Rican intellectual participation in studies of tropical biology. . . is, with a few notable exceptions, still meager. Research on Costa Rican biodiversity and ecology must become a priority in our own academic institutions. . . (44)

Knowing as much as possible about the natural environment, how ecosystems are interrelated, and how they affect humans (as well as how man affects nature) is the key to understanding why and how to protect it. The beginning of this understanding, notes Gerardo Budowski, was the country's physical geography itself--"forests and volcanoes" and later "a friendly, democratic republic" made Costa Rica an enticing destination for foreign scientists. Dr. Rafael Rodríguez has classified these ventures by foreign and local scientists into three categories: the early nineteenth-century explorations (like those of Carl Hoffman, Moritz Wagner, Karl Scherzer, and Helmuth Polokowski), those of the turn of the century (i.e. Henri Pittier, José Zeledón, and Clodomiro Picado), and the post-Depression years in which scientists 
have made many in-roads in understanding the country's biological 45

diversity. Each of the stages has left its stamp on the country's conservation history.

But if the number of Costa Ricans with advanced degrees in the biological sciences is small, the number of Costa Ricans who support conservation is large. Most may not actively lobby for ecological issues, but many do support the causes that will preserve their natural heritage. This support is rooted in the legacy of Costa Rica's emphasis on tropical science and is manifested in society today. 


\section{CHAPTER 2}

\section{THE ENVIRONMENTAL PROBLEM}

From the beginning of humanity, man has maintained a close contact with nature and has obtained from it the necessary resources for his subsistence. . . . Contemporary man, in the same form as his long-gone ancestors, depends on the natural environment to satisfy his basic needs.

- Luis Fournier (1)

\section{An Historical Setting}

The point at which dependence on the natural environment becomes exploitation of the natural environment is the problem addressed in this chapter. Today, as was noted earlier, a large percentage of Costa Rica is deforested and suffers from degraded land, erosion, and habitat loss for many species of flora and fauna, including a large number of endemic species (ones native to that area and not found elsewhere). Exactly how this scenario unfolded deserves careful, historical study to understand the dilemma and Costa Rica's responses to it.

Costa Rica's unique geography forged a distinct land-use pattern for native peoples and European settlers. Some anthropologists have argued that indigenous people, who inhabited Costa Rica for at least 10,000 years before the arrival of Spaniards, did little to deteriorate the natural environment. Indians recognized the areas where not much would grow and did little to alter that land's condition. In fact, Indians primarily developed agriculture in only four of Costa Rica's twelve life zones (premontane moist forest, promontane wet forest, tropical moist for- 
est, and tropical wet forest) and limited cultivation to such local crops as yuca (manioc), chiles, tomatoes, beans, corn, avocados, pejibayes, and other native fruits and vegetables. Likewise, they fished, hunted native animals, and gathered wild fruits and nuts. Carolyn Hall explains that "Indians exploited the natural environment while simultaneously conserving its potential resources."

In order to conserve, the Indians learned resource management techniques. They cleared forests with controlled burning in small parces (referred to as swidden agriculture) and, to guard against erosion during the rainy season, seeded the areas with various plants which provided a permanent cover. Their small, stable population necessitated subsistence farming only--producing enough food for the family or basic community units. One study that compared archaelogical evidence to present day indigenous activities concluedes that "[i]t might seem like a paradox that we consider the Indians as conservers of their environment because it was precisely from their system that we inherited the custom of burning terrain and even the practice of hunting, fishing, and gathering, or in other words, a production economy that is also extractive and exploitative."

The Spanish agricultural experience in Costa Rica, however, was exploitative in a different way. Early settlers not only gathered and cultivated native products but soon introduced such European commodities as sugar cane, citrus fruits, cereal grains, and livestock--what Carolyn Hall terms "ecological colonialism" 
and Alfred Crosby calls "the Europeanization" of the flora and fauna. Crosby includes Costa Rica in his list of "NeoEuropes" that were characterized by "biological expansion" or "ecological imperialism" in colonized parts of the world. Put in another way, as a different study suggests, the "Europeanization" process can be defined as "an amalgam of what they [the settlers] discovered, what they introduced, and what they fashioned for themselves." 5

Because the colonizers considered Indian ways inferior (less productive) to European agriculture, they initiated a slow, continuous deforestation process. The lands became dedicated to livestock grazing and to the cultivation of crops like tobacco, sugar cane, and other non-native species which disrupted the indigenous way of life in those regions. The comparatively few resident Indians in Costa Rica were not used as slaves near to the extent that they were in the more mineral-rich parts of the Spanish New world. Instead, they were pushed out of areas the European settlers wanted, or captured and sold as slaves for other parts of the Spanish Empire. Their "empirical knowledge of ecologically appropriate" agriculture, as Hall has described it, was ignored by whites and relegated to the small group of Indians is isolated from colonial settlements.

Environmental impact during the colonial era, however, remained limited due to Costa Rica's relative isolation and low population. While colonial farming practices were inappropriate for tropical environments, the crops produced were foodstuffs for a 
small colonial population at home or tobacco and cacao for local and regional markets. Early colonial agriculture (limited to the 7

Central Valley) had relatively little impact on the land.

Everything changed in the late 1830 s when coffee was found to thrive in some of Costa Rica's climatic zones. Many thousands of acres in sloped, cool terrain were cleared for coffee cultivation. What developed for Costa Rica was an agricultural export commodity with subsequent growth ramifications. The emergence of a coffee elite class meant that large landholders dominated the coffee industry and an agroexport oligarchy of merchant elites controlled the trade of coffee to foreign markets. Both groups came to dominate politics competitively and advocated increased production. Unlike many parts of newly independent Latin America, however, this trade was controlled by local Costa Ricans and not by foreign interests. As demand increased, the elite were motivated to turn more and more acres of previously undisturbed forest into coffee fields. Since 1845 (the beginning of the coffee trade with Great Britain) the government of Costa Rica provided further incentives for these efforts through lucrative tax breaks to the growers. For more than forty years thereafter coffee was virtually Costa Rica's only export product.

But in Costa Rica an incipient conservation awareness was already starting to emerge, even during the early years of statehood. Not all farms were large landholdings, but small or large, as Luis Fournier notes, the scale of agricultural deforestation in those years had "little marked effect on the environment." 
The Spanish, and the Costa Rican, growers had "enough ecological sense to settle in regions where the soil and climate were sufficiently satisfactory for agricultural activities."

Likewise there were early calls for conservation. As far back as 1775 the Spanish governor of Costa Rica, Juan Fernández de Bobadilla, issued a proclamation to discourage controlled burns on the basis that they were clearing too much land of forest cover and causing soil sterility. In 1833 and 1846 there were decrees regarding forest preservation (the latter pertaining to forest cover near cities). In 1888 a decree to protect watershed areas in mountains was announced and by the early twentieth century there were calls for a national forestry code. Hunting laws were enacted by 1853 as a means to conserve wildlife. And, very importantly, a further deterrent to environmental degradation was Costa Rica's low population which in the early years of statehood was less than one person per square 10 mile.

on the other hand, the advent of the banana industry towards the end of the nineteenth century and first few decades of the twentieth signalled an even greater agro-export phenomenon with greater environmental consequences. Unlike coffee, banana plants grow in low, humid zones, can be harvested year round, and are less susceptible to yield variations. For these reasons and because there was a robust market in the relatively nearby United States, bananas were introduced into Costa Rica's Caribbean lowlands in the late $1870 \mathrm{~s}$. They thrived there and came to dominate 
the agricultural landscape of lowland Costa Rica.

A major difference from the coffee industry is that banana production requires a large, expensive labor and transportation infrastructure. Plantations could be managed and produce shipped to ports only with great investments of capital. Capital and labor needs like these discouraged small farmers from entering the banana business and opened the door to foreign multinational corporations. Such was the case in Costa Rica where the United Fruit Company (UFC) came to monopolize the banana scene.

But because absentee landowners have significantly less contact with the land and are more interested in a good return on their investment than in ecologically sensible agriculture, the banana industry became damaging to the Costa Rican environment. Banana growers (bananeros) practiced continual forest removal to raise banana plants since a banana field's productive life is Iimited to seven years. More destructive were Sigatoka and Panama disease (caused by the soil fungus Fusarium oxysporum) which rendered banana fields infertile and caused the bananeros to clear more forest for plantations. The diseases forced United Fruit to abandon most of their Caribbean lowland banana fields by 1940 and move their operations to the Pacific Coast of Costa Rica near the town of Golfito. Using UFC records, William Holliday has figured that from 1900 to 1965, nearly 75,000 hectares (185,000 acres) of forest were clear cut for bananas. From 1966 to 1990, however, the pace of deforestation greatly quickened with estimates as high as 62,000 hectares $(153,000$ acres) a year-- 
representing up to eleven percent of Costa Rica's annual defor11

estation.

Clearing land for banana fields, however, is only part of the banana deforestation picture. Where before there were cart roads, railroads by 1890 (on the Atlantic side) and 1930 (on the Pacific side) were constructed to haul bananas to port and opened up new areas to developers. Cattle ranches were needed to feed the growing number of plantation workers. And when plantations were abandoned, like the ones near Limon by 1940 and the ones near Golfito by the early 1980s, banana workers flocked to the countryside to settle, farm, and eke out a living in the forest environment. Holliday concludes that with these infrastructure and social impacts, deforestation due to banana expansion accounted for up to twenty percent of Costa Rica's total annual 12 deforestation rates.

The historical setting is now in place to understand what has happened to Costa Rica since 1950 and to appreciate the corresponding conservationist responses. What economist Osvaldo Sunkel has referred to in Latin American history as "extraregional interventions in search of natural resources" have economic and sociologic repercussions outside the scope of this 12

study. More germane is the experience of the banana industry in providing a base for intervention that would forever change the environmental face of Costa Rica. 
Costa Rica's past experiences with land use have led to a late twentieth-century agricultural dilemma. The problem teeters between agro-development (for short-term economic prosperity) and environmental management (for long-term protection of natural resources. The noted Latin American economist Raúl Prebisch refers to this dilemma as a "technical ambivalence" where increased productivity has a made an "enormous contribution to human welfare - . but at the same time has had serious consequences for the 13

biosphere." The Costa Rican case of this phenomenon since 1950 merits attention here.

Referred to as the "era of transformation," the 1950 s serve as a threshold because of the degree of change experienced on the 14 Costa Rican agricultural scene. Up until this point, the "dessert crops" (coffee, bananas, and to a lesser extent sugar, cacao, and tobacco) dominated agro-export production. The post-war world economy, however, affected Costa Rican production. European and North American demand for Costa Rica's products fell after World war II because other tropical regions (i.e. Africa and Southeast Asia) began vigorously competing on the world market. In the late 1940 s and early 1950 s African palm trees were introduced in Costa Rica on former banana plantation lands to begin a palm oil industry (for the manufacture of margarine and other products) as a way to diversify the agricultural economy. Like bananas, this exotic species thrived but required capital intensive management. 
Another development affecting Costa Rica was the sharp decline in world coffee prices in 1958. Coffee, long Costa Rica's sole means of economic leverage in the world import/export arena, nevertheless was always vulnerable to demand and at the mercy of foreign land speculators and financiers. The government responded with its program of desarrollo hacia adentro (internal development) to promote manufacturing and encourage other agricultural 15 industries to develop in Costa Rica.

One commodity that emerged in the 1960's and $70^{\prime} \mathrm{s}$ was cattle Since the colonial years when Spanish settlers introduced domestic livestock to the Central Valley, cattle have thrived on the lush valley grasses and have supplied beef for local markets. In 1855 Carl Hoffman described how the valley was "perfect for cattle." The "superabundant meadows, eternally green, fresh, and maintained by the cool temperatures and daily showers," he wrote, were the ideal "natural conditions [that] have given to industrious men [the means] to establish a great cattle business."

The cattle business, however, remained limited to providing beef for local and regional consumption until the 1970's. Then, an exponentially growing North American market (strongly rooted in the need to supply fast-food restaurant chains with hamburger due to a sharp shortage of cheap cuts in the United States) encouraged Central American countries to expand ranching interests. Costa Rican farmers, ranchers, and speculators leapt at the opportunity, especially having discovered that the Asian zebu breed of cattle was so well adapted to the terrain and cli- 
mate of Costa Rica. One of the oldest living species, the zebu (with the easily recognizable hump between its shoulders and large, floppy ears) has lived for millions of years in India and is considered to be the most widely distributed breed of cattle on Earth today. In a 1969 article, La Prensa Libre (a large San San José newspaper) explained to its readers why they were seeing such dramatic increases in the number of zebu around the country. Calling it the "ideal bovine for the tropics," the article related how zebu have great resistance to tropical diseases, are able to move their flexible skin to shake off pesky insects and to eliminate excess heat (unlike European breeds which cannot), and can easily graze on steep slopes. That zebu are not susceptible to hoof and mouth disease made U.S. import approval possible and gave meat dealers the green light to wholesale the beef to the hamburger chains.

Zebu cattle seemed to be a perfect match for Costa Rica and by 1986 the country was the number one beef producer (eighty-nine million tons) in Central America. Jeffrey Leonard reports that thirty-six million tons of this total were exported, ninety-six percent to the United States, which received more beef from Costa Rica than from any other Central American country. Another authority on the Costa Rican beef industry explains that this importation was based on U.S. Department of Agriculture fixed quotas for imported beef. In the late 1970 s USDA policy allowed for a staggering 9.8 percent of all imported beef to be from relatively 18

tiny Costa Rica. Cattle raisers there worked hard to meet the 
annual challenge.

By the 1980s, however, this "volatile dependence" on the United States, as Susan Place explained it, became hostage to a "fluctuating market" and to the whims of the U.S. Congress which established and changed (lowered) these import quotas. The emphasis on exporting beef triggered a variety of social and environmental impacts. One social impact was the significant drop in locally consumed beef. Simply stated, there was less meat available due to the push to raise cattle for export. Local prices for dairy products and beef subsequently climbed which lowered the overall standard of living for the nation. To illustrate the dilemma, the scarcity of local beef was especially noted by the MCDonald's hamburger chain in Costa Rica which in 1977 had 19 to import 140,000 pounds of meat a month from Guatemala.

The powerful Cámara de Ganaderos (Cattlemen's Trade Association) lobby was extremely influential in gaining and maintaining governmental support for export production. The government provided such generous tax and credit incentives to ranchers that many dairy farmers switched to raising zebu for beef. The number of cattle raised in Costa Rica tripled in three decades: from 607,850 head in 1950 to $2,050,350$ head in 1985 .

This kind of cattle industry requires massive amounts of pasture. Not exactly known as a prairie republic, Costa Rica had to manufacture pastureland through systematic deforestation efforts. By 1980 over 6,500 square miles, or about one third of Costa Ri21

ca, had been converted to pasture. More importantly, according 
to land use capability (IUC) studies, only nine percent of costa Rica is ecologically fit for pasture-land, meaning that the other twenty-plus percent is damaged. Julio Calvo, a forester at Costa Rica's Institute of Technology, argues that this land is "suffering from erosion and loss of productivity owing to inappropriate management." Geographer George Guess suggests that because of erosion, Costa Rican pastureland "works towards its own obsolescence with tragic efficiency." Fifty-four percent of the damaged land has been identified by LUC as land that could be used for 22 annual crops.

More alarming than these pasturelands figures is the rate of forst loss. Costa Rica in the 1980 s and early 1990 s was losing four percent of its forested land a year--a rate that was higher than elsewhere in the Western Hemisphere, despite the more publicized information on deforestation from the Brazilian Amazon.* A more thorough investigation of deforestation follows, but suffice it to say here that while cattle production at one point seemed like an economic salvation, it instead added to Costa Rica's agricultural dilemma. It lowered the per acre output of production, eliminated other crops, and increased the amount of food to be imported for local consumption. An estimated 96,000 to 192,000 acres are taken out of crop use annually for the cattle industry. Most of the conversion has been for short-term value

* El Salvador, Haiti, and Cuba have even less percentage of remaining forest cover, but because not much forest is left, the rate of deforestation has slowed in those countries. 
only and has had heavy environmental consequences--part of costa 24

Rica's struggle to confront an economic reality. Deforestation also became a significant rallying call in the enviornmentalist community, and action was taken before all remaining forests were destroyed.

Similar to the situation with cattle pastures, the history of the banana industry represents a significant chapter in Costa Rica's agricultural dilemma. Minor C. Keith completed the Internatioal Railroad of Central America and helped found the United Fruit Company in 1898 as a means to bring bananas to a rapidly growing market in the United States. As mentioned earlier, the Caribbean lowlands of Costa Rica were perfect in climate and soil for the banana venture and soon thousands of acres of tropical forest were converted to banana plantations. Yet by 1950 ninety percent of the region remained in forest cover. By the 1990s, however, the figure was only twenty-five percent. (See Figure 1 for comparative maps of Costa Rican deforestation.) Ninety-six thousands acres (ten percent of which was primary forest) were cleared for banana plants in the six-year period of 1986-92 26 alone.

What has happened since the 1950 s is the story of the startling growth of an agricultural commodity industry that owes much of its success to cheap labor, chemical pesticides, and a receptive government. The results are continued deforestation and environmental health hazards. A landmark study of the banana problem in the Sarapiquí region of northeast Costa Rica defines the 
Figure 1: Costa Rican Deforestation over Time
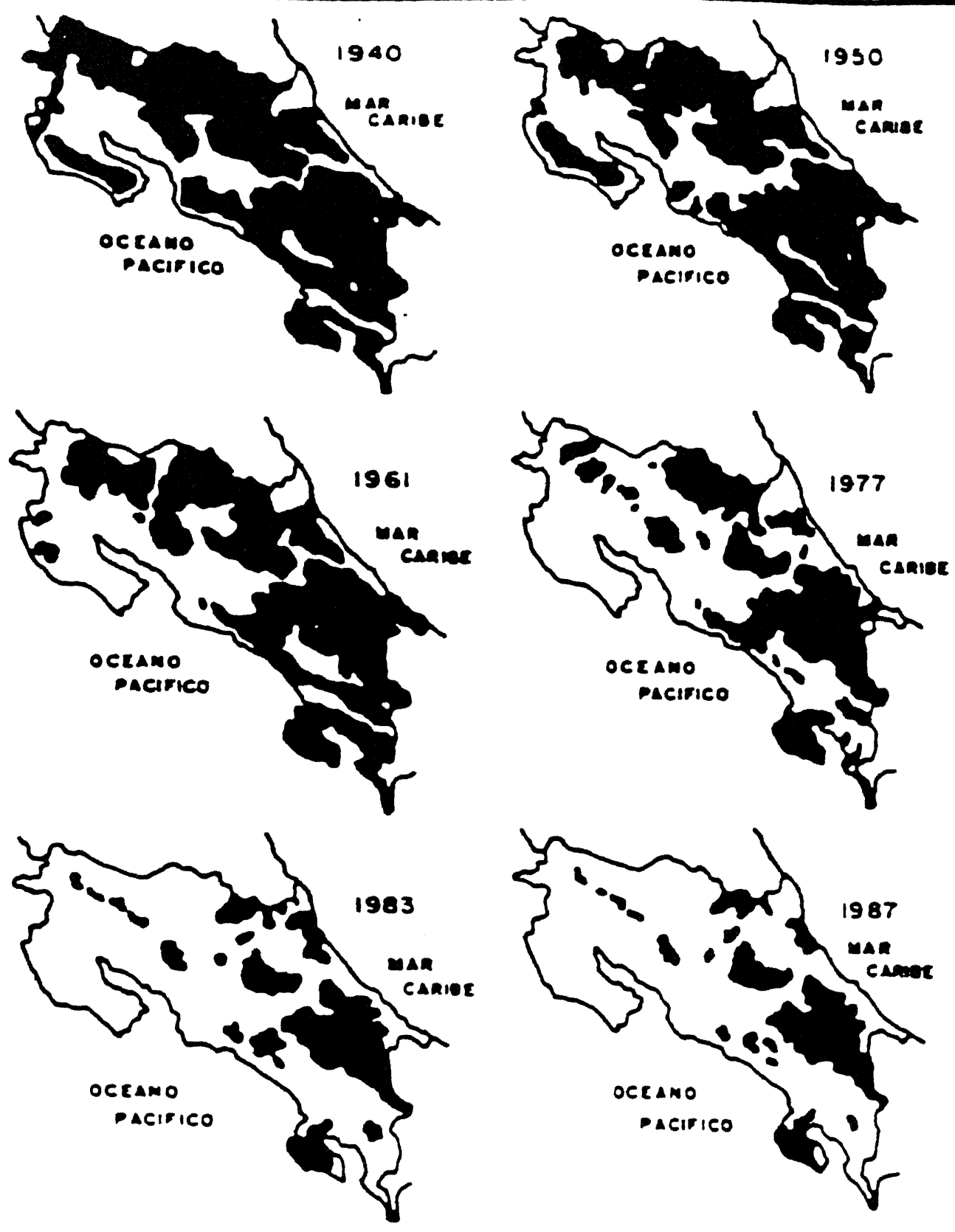

(source: Fundacion Neotrópica) 
environmental transformation as a six-step process: economic opportunity due to market expansion (in this case, Europe), the purchase or governmental concession of land (including rainforest "which is promptly cut down"); the importation of workers (historically from the British West Indies, but more recently from Nicaragua); the release of a large percentage of the workforce when their service is no longer required; the workers' usually unsuccessful search for other employment (and thus their search for land on which to grow subsistence crops); and the resultant forest invasions which causes more deforestion. "In this way," the authors of the study conclude," Costa Rica, one of the world's showcases of conservation, is currently promoting a policy that actually encourages rain forest destruction."

The three major banana producing multi-national corporations (United Brands [Chiquita]), Standard Fruit [Dole]) and Bandeco [Del Monte]) plus several other producers have all been dependent on chemical pesticides for increased harvest yields. These yields, however, have been accompanied by environmental and public health disadvantages. In a study entitled "Effects of Banana Expansion on Human Health and the Ecological System," University of Costa Rica scientists Leonardo Mata and Alfonso Mata summed up the situation by writing that "an environmental and sanitary disaster generated by the banana plantations" was the result of the industry's "predominant interest in the economics, over the ecolo28 gy," of the crop. For example, standard Fruit was using the fungicide DBCP (dibromochloropropane) in the early 1970 s until it 
caused sterility in two thousand workers. They sued the company in a U.S. court. Similarly, according to the Mata and Mata study, seventy-six percent of all pesticide poisoning claims at the National Insurance Institute were filed by banana plantation 29 employees.

Banana production also has been the source for other forms of pollution in Costa Rica. A well publicized case in point was in the early 1980s when scientists discovered that Cahuita National Park (the country's first coral reef protected area on the southern end of its Caribbean coastline) was suffering from sediment runoff from nearby banana plantations in the Estrella River Valley. A graduate student in biology named Jorge Cortés investigated the situation and ended up writing his Master's thesis on the sediment runoff that was endangering the coral environment. Heavy concentrations of iron, lead, copper, and other metals were flowing down the streams from the banana plantations into the Caribbean and building up on the fragile reef. Cortés, now a marine biologist specializing in coral reefs at the University of Costa Rica, claims his work on the Cahuita crisis was the "first such work on the subject" and was aimed at "creating an awareness" for the danger involved to the marine ecosystem. But while the Estrella River Valley plantations were penalized and instructed to stem their chemical runoffs, according to Cortés who in the mid-1990s conducted a follow-up study at Cahuita, the situation is "even worse" now with sediment build-up in the soil and 30 mud. 
Many other cases of fertilizer and pesticide runoff from banana plantations (one form of non-point pollution) have been evidenced in Costa Rica. In 1992, for example, toxic nematicides from plantations near Tortuguero (Limón Province) were linked to a massive fish kill. A lagoon near Tortuguero was "white with dead fish" floating in it. Even so, the director of the Ministry of Natural Resources at the time, Hernán Bravo, claimed it was difficult to trace the exact origin since it was 31 non-point contamination.

Likewise, waste generated by the banana industry has been cause for concern. The Mata and Mata study found that $3.5 \mathrm{mil}-$ lion tons of waste a year were produced by the plantations. An IUCN report claimed that 2.14 tons of waste (three fourths of which is non-biodegradable) are produced for every ton of bananas. Part of the mess has been due to the blue plastic bags used to protect bananas hanging on the plants from the damaging rays of the sun. The bags were typically removed in the field, tossed into the streams or canals, and carried off to the sea adding ocean pollution and endangering giant turtles and other 32 marine life. In 1992, under heavy pressure from local and international environmental groups which were threatening worldwide banana boycotts, a consortium of banana growers agreed to construct a recycling plant for the plastic bags (to be Costa Rica's largest recycling center), formed a Banana Ecology Commission, and started a "zero plastic" program. According to reporter Michelle Sheaff, it appeared as if the banana companies were 
"turning green." Local environmentalists, however, were wary of the promises and were concerned that the recycling be performed in an ecologically responsible way. Since then, as Jorge Cortés 33

notes, the problem with blue bag pollution has improved.

The dilemma with Costa Rica's banana industry is both environmental and social. Some plantation owners say they are working to reforest their lands. Jorge Cortés claims none have done so. The owners claim to bring in thousands of jobs to the country, but bringing more people in can be part of the problem. Luis Fournier notes that importing seasonal workers is a huge "demographic problem" and is Costa Rica's number one environmental challenge for the twenty first century. He cites as evidence the large influx of Nicaraguan laborers seeking work on banana plantations and the pressures on the environment and public ser34

vices that have resulted. The immigrant work force is in part response to the fact that most Costa Ricans refuse to do the work (hard labor, low pay, etc.).* But perhaps the problem has a wider base. Hardly limiting the blame to the government of Costa Rica or the large corporate plantations, John Vandermeer and Ivette

* Two prominent conservation leaders in Costa Rica disagree with Dr. Fournier on this overpopulation/foreign workers point. Alexander Bonilla (personal interview, July 1996, San José, ) claimed that workers have to have a job and a place to live before they can even begin to think about conserving resources. They should not be neglected, he argued, but should be encouraged to learn sustainable agriculture for survival. Likewise, environmental attorney Roxana Salazar stated in an interview (July 1996, San Jose) that the banana workers do not represent "an ecological problem." In addition, she noted that recent immigration legislation (i.e. the Nicaragua/Costa Rica convention that facilitates legal immigration) is working to address the problem. 
Perfecto assert that the "same biologists, ecologists, and ecotourists who love the rain forest when they're in Costa Rica also love to slice bananas on their cereal in the morning." They suggest that "with our penchant for viewing the world in isolated little disconnected fragments, it is apparently difficult for us all to see the connection between the knife that slices the banana in our cereal and the chainsaw that slices tree trunks onto rain forest floor."

Agriculture in general cannot be ignored in Costa Rica. Agricultural land covers one half of Costa Rica (although only ten percent of the country is cultivated) and is the number one industry. Two thirds of the national economy revolves around agriculture with bananas as the number one crop (still controlled by foreign corporations), followed by coffee, sugar, and of course beef. Cacao is still an export crop but is raised primarily on small farms. Food crops like rice, corn, beans (the principal source of protein for most Costa Ricans), fruits (especially pineapples), vegetables, and palm oils are other secondary, but important, products. There are many small subsistence farms, but about three fifths of all costa Rican farms are either medium sized (that use family members and hired labor) or minifundias-farms that grow subsistence crops and some export products. Large estates make up only three percent of Costa Rican agriculture and are said to be "the most extensively exploited [but] 36

least productive" units. Cattle ranchers tend to take too much land out of more useful, sustainable production and, as one 
study notes, employ "few and enrich even fewer." Costa Rica has had limited success with land reform but it often has not been compatible with the government's emphasis on agricultural devel37 opment.

Hopes to stimulate the economy in the 1970 s and 1980 s by producing more internationally marketable products (an economic theory known as "comparative advantage") prompted more land to be cultivated. Thousands of acres were turned into citrus groves and ornamental plant fields. Visions of high yields necessitated the introduction of great quantities of chemical fertilizers and pesticides that the crops required. To cope with with the debt crisis of the early 1980s, Costa Rica further accelerated these measures. The International Monetary Fund (IMF) insisted that Costa Rica produce more nontraditional crops like pineapples, flowers, and ornamental plants that could be sold in an evergrowing world market to generate capital flow to help satisfy creditors. By the late 1980 s these nontraditional crops accounted for thirty percent of all Costa Rican agro-exports.

While international lending organizations considered this a success, Costa Rica was experiencing difficulties with comparative advantage. Major multi-national corporations (i.e. Del Monte, United Brands, and Phillip Morris) were controlling the growth of export products while not enough beans, rice, and corn were being planted to feed the nation. "Frijoles sí, flores no ("beans yes, flowers no") became the rallying cry for a 1987 campesino protest, led by farmer-activist Carlos Campos, to pro- 
test the policies. Warning against an agrochemical "dependency," Campos wrote that "the reality is that we Costa Ricans are now dying, that we are destroying our soil, and from now on we should begin to demonstrate that, as farmers, it is necessary to present 39 alternatives."

Some studies are more specific about the environmental harms of agricultural specialization. Referring to the abuse of chemical fertilizers and pesticides as a "modernizing artificialization of the ecosystem," Nicolo Gligo lists erosion of farm land, sedimentation of waterways, non-point pollution, salinization, increased flood potential, soil sterility, deforestation (and its resultant diminishment of biological diversity) as problems stemming from monocultural agriculture. Moreover, "altering the natural architecture" and modifying the "topologic composition" produces far fewer calories for the people than the natural ecosystems themselves. The rate of infant mortality began to climb in the mid-1980s due to decreased nutrition from less available or 40 overpriced commodities needed by poorer peoples.

From 1950 to the 1980s, then, Costa Rica sustained vast environmental damage from its agricultural development. It has been suggested that "Costa Rica was rapidly becoming a runaway train on a steep and curvy downhill grade" before policies start41 ed to change to preserve what environment was left. Much of the terrain that changed had previously been forested--a topic that needs to be discussed next before an analysis of conservation efforts can be properly understood. 


\section{Deforestation}

The loss of forest deserves special attention here because of its impact on the environment and its importance to the development of a national conservation awareness. Former Costa Rican president and Nobel Prize winner Oscar Arias stated in 1988 that

we have made very important steps for the preservation of our natural heritage. . . but at the same time we deplore the sad leadership we possess in destroying our forests. No country in Latin America has a higher rate of deforestation than ours; today less than five percent of the nation's dense forests exist outside of protected areas. Such a paradoxical situation constitutes a serious threat to the advanced successes of conservation. (42)

The rate of deforestation alluded to by President Arias is alarming. It has been estimated that before any humans lived in there 99.8 percent of Costa Rica was covered with forest. The trees evolved by succession--the process whereby some species adapted, thrived, and when dead made way for other species to move in. But by the 1980s approximately sixty-five percent of Costa Rica was deforested. In the high development 1970 s Costa Rica had the highest rate of deforestation in Central America, experiencing a twenty-nine percent forest loss in that decade alone. In turn, this led to seventeen percent of Costa Rica's land to be degraded with an estimated 680 million tons of topsoil a year being washed 44

away due to loss of forest cover.

While much of this loss was due to expansion of agriculture and pasturelands, which increased by 250 percent from 1950 to 1984, the timber industry is also responsible for massive deforestation. In fact it was the timber industry which first opened 
up many forests for agricultural development by constructing roads into previously inaccessible areas and clearing land for fields. By the late 1980 s there were 17,000 miles of roads in Costa Rica, more than in any other Central American nation. What B.E. Lemus in his book Costa Rica Crisis calls the "forest industrial complex" is big business timbering, most of which occurs on private land. However, because of imprecise surveying efforts, poorly delineated boundaries, and underbudgeted enforcement measures, logging (and the resultant pasturing) has occurred inside protected areas as well. And instead of using a plan of selective cuttings in forest reserves, timber companies have been clearcutting large tracts of densely forested areas for short term economic rewards. Two thirds of all harvested timber is consumed as fuel and much is wasted, as Carolyn Hall points out, due to "deficiency of extractive methods and the lack of industries to use the poorer quality wood." Such waste and non-sustainable harvests are fast resulting in a situation that some fear could make Costa Rica have to import wood for domestic use by the year 46 2000 .

Along the roads made to haul timber out of the backcountry came squatters--poor settlers called precaristas (literally, those in a precarious situation or living on the edge)--looking for land to farm and a way to feed their families in newly deforested areas. Colonizing farm lands in the tropical forests by such people was nothing new in Costa Rica. In the 1830s Alexander Skutch observed squatters moving into the El General Valley 
who were "eager to take possession of as much land as [they] could for this sort of agriculture." The squatters, he wrote, "obliged by law to clear and plant at least half [their] area" and during each dry season "renewed [their] attack upon the dwindling forest." He reminisced that

January and February were the chief months when the woods were leveled. At intervals throughout the morning, I would hear the dying groan of some great tree as it began to strain the shrinking band of wood between the axe cuts on opposite sides. Then came the billowy swish of myriad leaves rushing madly downward through the air and a thunderous, earth-quivering thud that reverberated far across the valley as the huge tree crashed down upon its final resting place. . . . Before they felled the tall trees, the laborers cleared away all the underbrush with their machetes. This made the forest parklike and most inviting. . . . But this idyllic state was usually of short duration. Soon the big trees were attacked and overthrown, the noble forest reduced to a scene of chaos and ruin. (47)

The precaristas of the 1960s, 1970s, and 1980s practiced similar agricultural techniques, although most used fire instead of an ax to clear the forest. The colonizers came out of the interior of the country and migrated towards the coasts. In 1961 the Law of Lands and Colonization (similar to the Homestead Act in the United States) was enacted.* It established an agency (ITCO, the Institute on Lands and Colonization) to aid the precaristas and imposed sanctions on landowners retaining uncultivated acres. ITCO encouraged migration in the early 1960 s to "improve" virgin "farm" land. But while the majority of precaristas squatted on land designated as farm areas, they did not settle solely

* A more detailed discussion of the history and career of this law follows in Chapter 3. 
on private land. The conservation organization Fundación Neotrópica reported that a staggering twenty-five percent of federally protected land was invaded at one time or another. Crop land and cattle pastures were established before the government could react and in many cases before it even knew. Likewise, some precaristas (without permission from the landowners) occupied and 48 attempted to farm plantation land belonging to foreign owners.

By the 1980s, colonization was becoming a significant economic, sociological, and environmental problem. Some estimates suggested that one sixth of all costa Rican families were precaristas. Making a long term, better living for their families, however, in many cases did not materialize. Cleared land and supplies were bought on credit. Interest rates and principal became difficult to pay when prices and demand on agricultural commodities dwindled. Price policies set far from where the campesinos worked dictated production needs without the squatters' knowing or ability to change crops. An even greater setback was erosion, occuring when land was cleared of cover and the topsoil and its nutrients would eventually be lost in runoffs during the rainy season. Crops could be grown for only three to five years when many peasant families were forced to sell out to large real estate firms who in turn sold the land to ranchers for use as pasture. Intensive grazing made the land suitable for only four to six years more before rendering it completely degraded. Meanwhile, the precaristas searched for and moved to new frontiers-renewing the destructive cycle. 
To be fair to the squatters, it is important to note that not all research shows precarismo to have had a negative impact. Beatriz Villareal, in her authoritative work El precarismo en Costa Rica, maintains that in 1973 (near the height of the precarista period) the squatters represented only eight percent of the rural population. Daniel Janzen has argued that "squatters have never been a problem on government or private land under conspicuous use" and that at Guanacaste National Park (a preserve that Janzen was instrumental in establishing) squatters would only take marginal land. Likewise the OTS in 1984 began an environmental education program for squatters living near its La selva biological station that was aimed at "treating them as friends and neighbors and not as invaders." A similar approach was used at Monteverde. There, the World Wildlife Fund and the Canadianbased Monteverde Conservation League sold tracts of land to precaristas for twenty-five dollars an acre to help them relocate away from endangered tropical rainforests.

When farmlands became ranchlands, however, displaced peasants were not absorbed into the cattle workforce. Coffee production requires 130 working days per hectare per year (rice sixty 50 and beans thirty-seven) but cattle require only six. Advances in agricultural technology also translated into less need for field hands. With so little work to be found in the country (and what work there was paid poorly), thousands of precaristas had no other choice than to return to San Jose or other cities--the completion of the colonization cycle. Twenty-five percent of the 
rural population $(n=150,000)$ became classified as "landless workers/farmers"--the highest percentage in Central America. Hence, a development contradiction emerged in the late 1970s when 90.3 percent of all land in production (reduced to eightytwo percent by 1985) for the cattle industry was accounting for only twelve percent of total agricultural exports and a small per51 centage of the GNP.

Those kinds of statistics prompted geographers and economists to conclude that the beef boom was actually "underdeveloping" the Costa Rican economy, increasing tensions among the people, and creating social and economic problems. They pointed out how the cattle industry had displaced a sustainable harvest of timber--resulting in a $\$ 4.68 \mathrm{million}$ net loss in the economy from potentially marketable hardwood trees. The cattle industry had become a "drag on the economy" instead of its greatest motor and had concentrated the wealth into "landed elite" by squeezing 52

out many small farmers.

The impact of deforestation on Costa Rica is indeed multifaceted. There is not only the obvious loss of trees (and therefore timber) but also the loss of wildlife habitat (especially of threatened and endangered species), scenic value, and watershed deterioration. Deforestation also results in river silting (caused by erosion on cleared lands), disruption of fisheries and traditional fishing grounds, abnormal flood/drought cycles, riverbank erosion, heavy soil compaction (from cattle), and soil sterility that often leads to complete desertification of the area. 
An important early study on the subject (from 1972) explained the desertification process by showing how forest areas that were cleared and not allowed to recover "never reached the climax stage [of succession]." The clearing caused a "reduction in organic matter and nitrogen removal of the original vegetation exposing the soil to full sunlight and to receive the full impact of rainfall." In turn, surface temperatures rose and humidity fell. If the area was burned, the deterioration process was mag53 nified.

In addition to the negative environmental effects, deforestation caused serious economic problems. The decrease in watersheds meant a reduction in hydroelectric generating capability thereby limiting the flow of electricity and reducing employment opportunities in some sectors of the economy. Soil sterility and overgrazed pastures led to an overall loss of potential economic opportunities from sustainable agriculture. The problem was grounded in a wide-spread belief in abundance theory--a lack of acknowledgment of a renewable resource problem. The theory was defined by one study as that pattern of thinking in the $1960 \mathrm{~s}$ and 1970 s based on the "belief that Costa Rica had more than enough resources and that no shortages would develop." In contrast to nineteenth-century agricultural patterns, many Ticos (what Costa Ricans fondly call themselves) in the last forty years have believed that "basically the entire country was suitable for agriculture and livestock and that forests were only impediments to development." Deforestation, then, was seen as an 
54

"improvement" to the land. But what Ticos thought might be a "giant step towards modernization," wrote geographer John Augelli, in reality became a "minimum of socially desirable and environmentally adaptive components [resulting in] painful social and ecological costs."

It took this kind of harsh reality for the goverment of Costa Rica to legislate against forest abuse. In the late 1960's the Ministry of Agriculture appointed a committee to study the problem and draft a bill that would enable the government to limit the deforestation cycle. The result was the Ley Forestal (Forestry Law) of 1969 which became a monumental turning point in Costa Rican environmental history. *

Article 1 of the Ley Forestal proclaimed that the law would establish "as an essential function of the state [the means] to guard the protection, exploitation, conservation and development of the forest resources of the country, in accordance with the principle of multiple use of natural, renewable resources." Conceived with the notion of "multiple use" (a concept borrowed from U.S. natural resource policy), the Ley Forestal placed all of Costa Rica's forests under the the charge of the Ministry of Agriculture and Livestock (MAG). Article 2 directed MAG to "conserve forest resources . . combat soil erosion, control the exploitation of forest resources... [and] conserve wildlife" among

* A more complete history of this legislation is discussed in Chapters 3 and 7 . 
other duties. Specifically for forest concerns and to be administered under the auspices of MAG, the General Forestry Directorate (DGF) was established in Article 9. Its functions included "to administer the forest heritage [defined in Article 18 to mean national parks, forests, preserves, and biological reserves] . . [and] to give technical assistance to the timber industry." And the Ley Forestal established other protected areas that would 56

not be open to development.

The Forestry Law of 1969, however, hardly slowed deforestation. In the decade following promulgation of the law, Costa Rica experienced a twenty-nine percent total forest loss. Several authorities have tried to pinpoint how this could have happened. Luis Fournier blamed the lack of long range planning despite increased awareness of conservation needs. Carolyn Hall explained how the law was not actively enforced and how the permitting process was ineffective. Permits were to have been obtained by forest users from the DGF before any timber could be cut from private or public lands, but the new forestry agency lacked "the funds and trained personnel to enforce the law." While the DGF was supposed to have complete control over all timber cuts, it has been reported that by 1989 roughly one half of all trees 58

felled lacked the proper permits.

Likewise, many thousands of trees were harvested in banned areas. Deforestation occurred in parks and on the perimeters of protected areas which affected their overall environmental integrity. Because funds were scarce, Bill weinberg reported, insuf- 
ficient vigilance near protected zones opened the way for "ranching, slash-and-burn campesino farming, high-pesticide corporate agriculture (such as banana plantations), or timber exploitation" on the borders of the parks and often extending into them. In 1971, only two years after the Forestry Law was enacted, forestry biologist Joseph Tosi of the Tropical Science Center issued what became a famous warning stating that by 1985 there would be virtually no natural forests left in Costa Rica if the deforestation rates of the time continued. Luckily Dr. Tosi's predictions for forest loss did not completely materialize, but by 1987 Costa Rica was still losing 120,000 acres of forest a year. According to a World Resources Institute study, the country's annual rate of deforestation in 1990 was 6.9 percent--the highest in all of 59 Latin America.

The bleakness of the above scenario certainly tested Costa Rica's image as a "green republic." Fortunately, the scenario is being offset by changes occurring in Costa Rica. Squatter colonization persists but has declined dramatically (albeit for more economic than environmental reasons) since the mid-1970s. In 1977 the Ley de Reforestación (Reforestation Law) was passed which was the government's first attempt to restore degraded forest lands. It was also a way toward fostering the belief that tierras incultas (uncultivated lands) could have values and uses other than development. The government repealed the tax on uncultivated farmland and established tax incentives, loan assistance, and technological help for reforestation efforts. It has 
been an expensive project that has not yet been totally successful on a nationwide basis, but has great economic potential for providing a sustainable wood products industry. One project near Turrialba called Programa de Diversificación (Diversification Program) has been successful in repopulating trees and employs the 60 services of local small-scale foresters.

Reforestation has many logical advantages. To list a few, the guaranteeing of watersheds, hydro-power, wildlife habitat, erosion control, and the diversification of local economies are among the most often cited. Currently, however, there is a lack of long-term financial investment and technology for reforestation to become totally successful and much of the land needed is located in private holdings. Lands that were formerly banana plantations are especially slow to reforest or to produce much of anything else. Likewise, there are many thousands of reforested acres that have become plantations of single tree species and therefore, as Hall relates, "insignificant in relation to the magnitude of the ecological problem they are intended to solve." The most common plantation tree crop in Costa Rica is that teakwood. Teak trees (Tectona grandis) are tall East Indian timber trees that are an introduced species in Central America and thrive in Costa Rica's lowland tropical areas, especially on the Pacific Coast. Teakwood is a hard yellowish wood that in the past was often used in shipbuilding. It now enjoys a healthy world market for other wood products, especially in the increasingly wood-starved Far East. The problem is that thousands of 
acres of deforested land are being proclaimed "reforested" by the teak industry. Advertisements across the country hail such benefits as erosion control, soil conservation, and wildlife cover that teak plantations supposedly offer.

The plantations, however, are a far cry from the original forest cover. Teak trees are planted in symmetrical rows, grow at even heights, have weeded and well-groomed rows between them, and are felled at the same time when mature. The reforested plantations "help the soil for awhile," forestry botanist Luis Fournier recently explained, "but eventually the soil deteriorates with more cuttings." The ads the industry uses, he asserted, do not give the complete picture and are used to get more 62 people (often foreigners) to invest.

As powerful a problem as deforestation is in Costa Rica, in many ways it did help wake up a nation to its environmental responsabilities. The voices of many started to become louder for the more rational conservation of natural resources. Lobbying became intensive for the designation of more and more national parks and protected areas. Part of that solution meant that the government would have to take a more active position in legislating protection and funding enforcement. Recent steps have been taken to crack down on wilderness exploitation. The Rural Guard conducts spot checks for illegally cut logs (often hidden in produce trucks). At the urging of the DGF (and despite great uproar from the timber industry, the government declared a state of emergency concerning the deforestation crisis in the late 1980 s. 
Agencies can now suspend permits to cut trees outside of private plantations and can prohibit the export of unfinished wood products. Likewise, funds have been earmarked specifically for the enforcement of these measures.

The government also has encouraged sustainable development of forest resources (to include agriculture, sylviculture, and tourism) to protect its tropical forests. Programs in environmental education have assisted this effort. According to Weinberg's study, "sustainable development" is "virtually a household term among educated Costa Ricans. . . "

None of these successes occurred spontaneously. Environmental reforms, reforestation, national park development, and ecological education did not occur in Costa Rica without the will and determination of the costa Ricans. The result can be seen in the history of Costa Rican conservation, as will be discussed in subsequent chapters. 


\section{CHAPTER 3}

\section{THE CONSERVATIONIST RESPONSE}

The national parks belong to all Costa Ricans equally, and therefore they have the right to enjoy them . . . but also the duty to protect them.

- Mario Boza (1)

\section{An Overview of the Costa Rican National Park Experience}

What do the words "model," "example," "beacon," "showcase," "prototype," "the ideal," and "wave of the future" have in common? Answer: all repeatedly have been used to describe Costa Rica's national park system. The descriptions are used to refer to the parks' diversity, number, size, management plans, beauty, and quickness in being established. The 1970 United Nations List of National Parks and Equivalent Reserves listed no national parks or protected areas in Costa Rica. Six short years later, however, a different U.N. study called A Manual for National Parks and Planning referred to Costa Rica as a model on how to preserve natural areas and on how to create master plans to pro2

tect flora and fauna. By 1980 Costa Rica had more protected areas and more personnel working on conservation issues than any other Central American nation and a greater percentage of land designated as national parks or reserves than the United States. (See map, Figure 1.)

The figures today speak for themselves: twenty-eight percent of Costa Rica is designated as legally protected land (eleven percent in national parks, four percent in indigenous reserves, and 
Figure 1: National Parks and Equivalent Reserves of Costa Rica

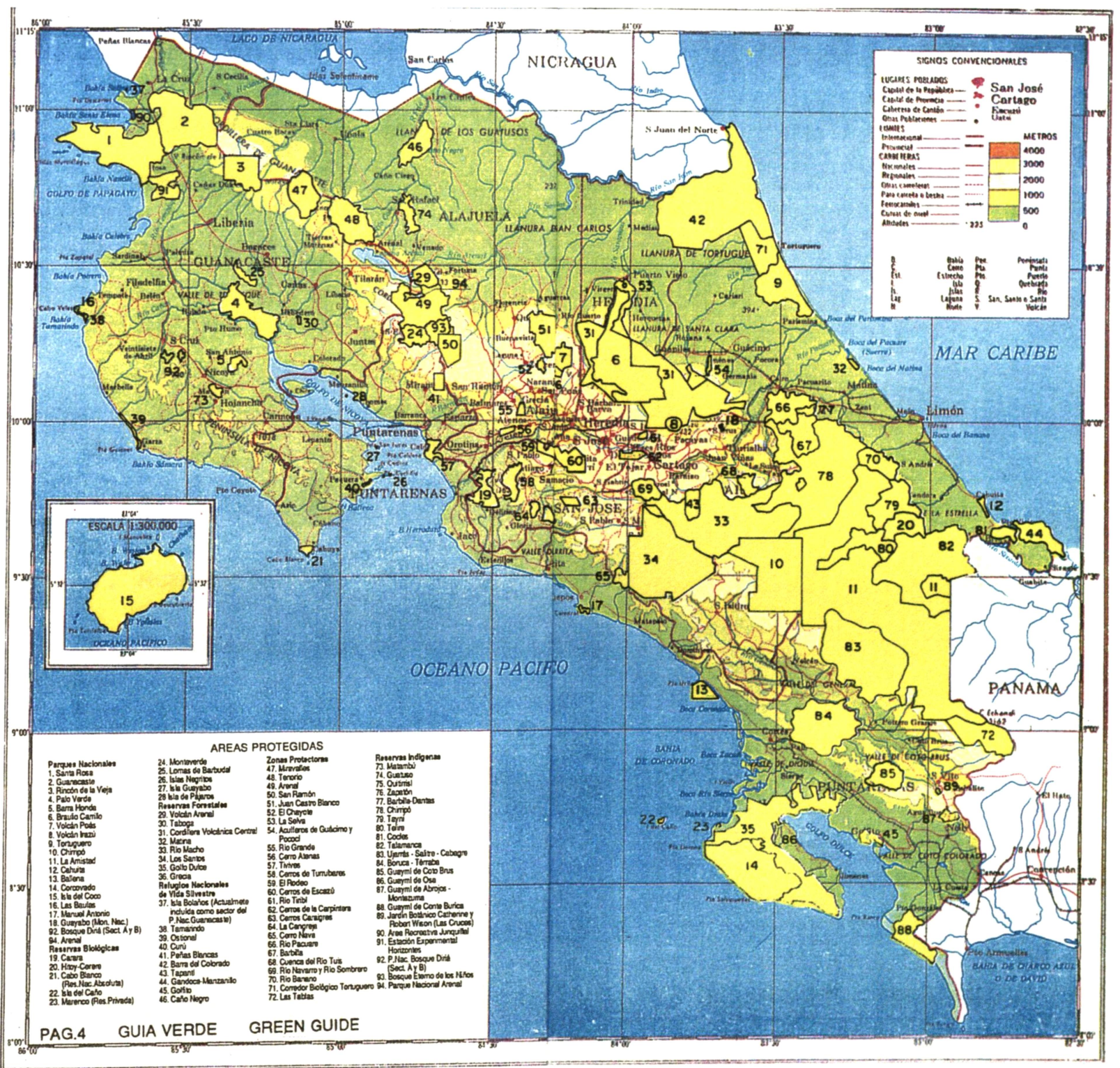

(source: Juan Diego López Ocampo, Guía verde de Costa Rica [San José: Guŕas de Costa Rica, S.A., 1992]) 
thirteen percent divided among biological reserves, national for-

ests, national monuments, and national wildlife refuges). (See

Table 1.)

Table 1: Protected Areas in Costa Rica

Designation

1. National Parks

2. National Monuments*

3. Wildlife Refuges

4. Biological Reserves

5. Forest Reserves

6. Zonas Protectoras**

7. Humedales $\star \star \star$

8. Indigenous Reserves
No. of acres

$1,336,196$

3,624

397,820

94,954

651,920

426,730

96,485

536,316

Percentage of total

$37.7 \%$

$.1 \%$

$11.2 \%$

$2.7 \%$

$18.4 \%$

$12.0 \%$

$2.8 \%$

$15.1 \%$

total $3,544,045$

* includes two areas designated as "natural reserves"

** protected watersheds, buffer zones, and biological corridors

$\star \star \star$ state or provincially protected wetlands

(source: SINAC records as of Dec. 1995)

The Costa Rican park system is managed by SINAC (National System of Conservation Areas) which is a division of MINAE (Ministry of Environment and Energy). The protected areas are divided into three management types. Type I is "strict" protection (national parks, biological reserves, national monuments, natural reserves, and wildlife refuges) with the objectives "to preserve species [and] to reduce human intervention in environments and 
ecological processes." These areas also include archaeological or historically significant sites (i.e. the prehistoric Indian ruins at Guayabo National Monument or the Filibuster War memorial at Santa Rosa National Park). Over eleven percent of the total designated area is under this "strict" classification.

Type II includes forest reserves and protected zones whose objective is "partially to protect the biological diversity as they are open to exploitation of resources under certain conditions." They are managed for different degrees of multiple use development (i.e. tourism, logging, etc.). They allow limited logging but also were established to protect important watersheds, wildlife, and forage. Type III is indigenous reserves which are for "the conservation of cultures and their environments and the protection of life systems in these communities and the way natural resources are used." There are twenty-one Type III Indigenous Reserves.

The Forestry Law of 1969 (and its various revisions since) outlines the differences in the designated protected areas. Article 74 legally defines "national parks" as "those regions or areas of historic importance that are set off by boundaries determined by executive decree and that for their scenic beauty or the national and international importance of their wildlife are to be set aside for the recreation and education of the public, for tourism, or for scientific research." National monuments are smaller areas $(2,500$ or fewer acres), have less diversity or less natural and historic value than national parks, or are areas pro- 
tecting a specific resource. Biological reserves are "forest lands whose principal use is for conservation and research of wildlife and the ecosystems in which they exist." And national wildlife refuges are for "the protection, conservation, propagation, and management of wildlife species of flora and fauna."

Some of the language in the Forestry Law reflected a utilitarian multiple use perspective of conservation. The economic nature of Costa Rica's forest reserves (or national forests) is seen in Article 35-A (of the 1990 revision) which defines them as "forests whose principal function is for the production of wood." Logging and recreation have been high management objectives. Zonas Protectoras are defined as areas for "the protection of soil, regulation of hydrology, and conservation of watersheds." While these definitions are overtly economic in nature, one prominent conservationist acknowledges that the national forests are also the "lungs of the cities"--vital oxygen producers for so many aspects of the nation's health.

The importance of the national parks (and other protected areas) is multi-dimensional. In the large sense, preserving the "natural and cultural heritage" of Costa Rica, as Mario Boza has identified the primary objectives of protected areas, seems like the obvious mission of the national parks. But in a country with such broad diversity of environments and life zones, and one so entrenched in agricultural and economic uses of the land, that is no small task. Costa Rica has responded to the challenge, however, by developing parks or preserves in all of its identified 
geographic zones (with the exception of the wet lowlands montane forest which, according to Boza, has no representative natural or undeveloped areas remaining). The park service identified five management types of national parks to accomplish this goal: historical and archaeological, mountainous and volcanic, dryland forests, rainforests, and underground and submarine parks.

The scientific value of this preservation system is probably immeasurable. Guanacaste and Santa Rosa national parks, for example, are the only protected tropical dry forests in the world. Poas Volcano is one of the world's few remaining active volcanoes with year-round access for scientific study. Likewise, maintaining as natural a state as possible for tropical plant and animal communities represents, as Luid Fournier put it, an "endless fountain of educational and research material for all age levels." It also is a "deposit of genetic material" that has scientific, medical, and economic potential. The genetic value of species protection in habitat protected by Costa Rica's parks and preserves (what Fournier refers to as "open-air laboratories") may keep the country in the scientific limelight for decades to come. Furthermore, in the next fifty years these protected areas may be the only natural territories left in the entire country if development continues at its present rate. After a slide presentation on endangered tropical forests at a 1990 Legislative Assembly hearing to draft a new forestry law, Mario Boza (then Vice Minister of Natural Resources, Energy, and Mines) declared, "what you saw in the slides--the national parks are what have saved any for- 
ests that's left at all."

That Costa Ricans realized this threat and acted quickly to save as much as they could in all of the representative geographic zones (save the one listed) exemplifies their awareness for the environmental welfare of the country and the foresight of many conservation minded individuals. Their experience also has served as a regional model for an ecologically troubled Central America. Mario Boza and Rolando Mendoza wrote that the subject of of national parks is gaining in importance in other Central American countries due, to a certain extent, to the influence of Costa Rica. . . for example, the first Central American meeting on Management of Cultural and Natural Resources was held in San Jose to analyze, among other subjects, the zones proposed for a Central American system of national parks. . . (11)

And former President Oscar Arias took the importance of the parks one step further to include a global responsibility:

Our system of national parks and wildife areas protects individual ecosystems that are the paradigm of the extraordinary natural variety of which we are guardians. This is of vital importance not only for present and future generations of Costa Ricans, but for all humanity.

Early "Parks" and Conservation Laws

Similar to most countries in the world, conservation policies in Costa Rica were a mid- to late twentieth-century phenomenon. While there were no actual national parks in Costa Rica until 1970, there were some earlier measures that attempted to deal with preserving parts of the nation's natural heritage. One concept of protecting areas goes back to 1863 . It was then that the 
government set aside a tract of forest on both sides of the Camino del Norte (Northern Road) to be excluded from cuts. In 1906 the Legislative Assembly passed Law No. 36 which obligated the executive branch of government to recommend a general forest policy to the Assembly. Although there were some initiatives and orders made, the law was vague and no national policy was created.

An influential person in early conservation policy making was Enrique Jiménez Núñez. Jiménez had earned his graduate degree in engineering in Belgium but returned to Costa Rica where, according to one study, he "started to form a conscience about 13 environmental problems." Appointed to the office of State Secretary of Development and Agriculture, Jiménez promoted a plan to diminish the burning of forests which resulted in Law No. 121 La Ley de Quemas (the Fire Law) of 1909. The law established guidelines for the use of fire to clear forested land. Jiménez understood the connection between forest cover and water supply and wrote that burning mountainsides "destroys many of the principal sources of the public wealth, it disfavorably modifies the normal rates of rainfall. . . [and] has transformed the most prosperous and rich countries into deserts." Unfortunately the Fire Law lacked any strong enforcement measures and did little to prevent deforestation in the decades to come. Jimenez also advocated a project that would have nationalized all of Costa Rica's water systems in 1910 (which did not culminate into law) and devised a plan to eliminate the dumping of coffee plantation byproduct waste into rivers in 1914. 
Other conservation policies were enacted in the 1910 s and 20s. In 1913, for example, the government classified Poás Volcano as "protected" but provided no authority or enforcement to monitor the mountain. In the same year the government declared a 600 foot swath of forest inland from Costa Rica's coasts and an 800 foot swath along river banks to become the first "national forests." Again, there was a lack of clarifying language and authority to enforce any protective measures. Two laws were passed om 1923 aimed at preserving water. The first was Law No. 52 to prohibit the dumping of waste products from sewers, dairies, and slaughterhouses into the nation's rivers and the second was Law No. 68 for the protection of watershed systems.

The 1930s witnessed additional, albeit nominal, initiatives to protect the nation's forests. In 1930 a regulation was decreed to establish a system of forest guards (guardabosques) "who would have jurisdiction in the whole Republic to ensure the conservation and rational use of the forests." The enforcement of the act was placed in the office of the "Forestry Chief" of the 15 national agricultural department in 1933. Law No. 13 of January 1939 went a bit further and established "preserves" around Poás and Irazú volcanoes and in the forests on both sides of the Cordillera Central. The law, however, was really more like a philosophical resolution because it included no exact delineations or enforcement clauses. Called the Ley General sobre Terrenos Baldíos (General Law regarding Vacant Lands), this measure declared that all vacant lands "that have no legitimate title for private 
owners, have not been registered with the Public Register, [and] are not occupied by a public service" would belong to the state. The law also established the government's right to eminent 16 domain.

There was limited interest in conservation measures in the 1940 s as well. Recognizing the international aspect of preserving nature, Costa Rican delegates signed the Western Hemisphere Convention on Nature Resources in Washington, D.C., in 1940.* In 1943 when Costa Rica's segment of the Pan American Highway was constructed, biologists Charles Lankester and Mariano Montealegre proposed the idea of protecting as a "national park" a region on both sides of the road that they discovered was home to what they believed to be the world's largest oak trees. Law no. 197 of 1945 designated 6,000 feet on both sides of the highway as a "national park" (the first time such a term was used in Costa Rican legislation) and stipulated that no forest exploitation would occur in the area. Unfortunately, the law was never really put into effect, placed no one in charge of its administration, and therefore left the oak forests open for timber cutting. The law was abrogated in 1973, as former park service attorney Ana María Tato explained, "because there was nothing left to protect."

In 1948 a political upheaval ended in the revolution of $\mathrm{Na}$ tional Liberation that thrust José Figueres Ferrer into the presidency of the Founding Junta of the "Second Republic" of Costa

* It was not until 1966, however, that the Legislative Assembly ratified the convention. 
18

Rica (1948-49). The revolution, however, did not disrupt plans for a Costa Rican delegation to attend and participate in the Inter-American Conference for the Conservation of Renewable Natural Resources that was held in September of 1948 in Denver, Colorado. The conference, which was promulgated at the Third Inter-American Agricultural Conference in Caracas three years earlier, was a forum designed to share ideas from the countries in the Western Hemisphere and to promote regional cooperation on conservation concerns. One of the Costa Rican participants, for example, presented a paper on the growing interest in forest protection in his country and how the state should be actively involved in overseeing conservation to guarantee "a land with resources for the future. . . ."

José Figueres and the government of the Second Republic placed emphasis on education and social services, abolished the military (an act that Costa Ricans often cite as vital for freeing government funds for such things as higher education and, later, conservation), and established the Instituto Costarricense de Electricidad (ICE)--the country's public utility corporation that supplies electricity. Understanding the importance of forest cover for ensuring the hydrologic needs of the ICE, the Figueres administration issued a decree in 1949 to establish a Forest Council to inventory forest resources and to protect forested watersheds from diseases and fires. Although noble in theory, Luis Fournier later lamented that "in practice, this entity [the 
Council] was never put into action." It was eliminated four years later. Also in 1949, however, the agriculture and livestock ministry (MAG) added a "Forestry Section" division to its responsibilities. This proved to be a decisive move because the nation's forests remained under MAG jurisdiction until the mid$1990^{\prime} \mathrm{s}$

The administration of President Otilio Ulate (1949-1953) supported other conservation minded ideas. In 1950 the government established the National week for the Conservation of Natural Resources. The event was organized by an interdisciplinary amalgam of government agencies (including the ministries of public health, agriculture, industries, and education) and was designed to remind the citizens of Costa Rica of their duty to conserve soil and water for the long range benefit of the country. The commemorative week, always held in June, has been observed with celebrations, symposia, and special events every year since its inception.

In 1953 the National Agricultural School initiated legislation that resulted in the passage of Law no. 1540, the Soil and Water Conservation Law that was signed by President Ulate. Spearheaded by agricultural engineer Alvaro Rojas Espinoza, the law required that soil studies be conducted on agricultural areas to determine the rational use of the land. But it also contained language that authorized MAG to earmark areas to be protected as "reserves, parks, or national forests. . . for common use." De- 
spite the fact that MAG never took advantage of this opportunity, the law helped fuel a growing conservation awareness in the nation and, as Luis Fournier notes, was "perhaps the most important [legislative] event of the time period."

Other efforts that assisted conservation marked the second (non-contiguous) term of President José Figueres (1953-58). In late 1953, for example, Figueres named a study commission to develop legislation for the creation of a national tourism council. Commission members visited Peru, Mexico, Argentina, and the United States to seek ways to develop a park system in Costa Rica. Their work culminated in the passage of Law no. 1917 which created the Instituto Costarricense de Turismo (ICT) in 1955. Part of ICT's mission was to designate a 1.2 mile radius around each volcano crater in the nation as a "national park." But "without technical criteria for national park objectives at this time," reminisced a former park service official, "economic and ecological reasons impeded the execution of that dimension of the law." In 1958 an ICT study addressed where other national parks should be established, further emphasizing volcanoes and oak forests, but economic considerations once again thwarted implementation of the plan.

Costa Rica's first wildlife legislation was also a product of the mid-1950's. The Wildlife Conservation Law (Law no. 2093 of 1956 and its revised version, Law no. 2790 of 1961), defined wildlife as "those animals that are not domesticated or domesticated animals that have turned wild" and went on to state that 
all such creatures were "the property of the state." It declared that the wildlife were part of the "renewable natural resources of the country" and that the "conservation, restoration, and propagation of all wildlife useful to man" was of "fundamental interest" to the public. The law also spelled out hunting and fishing regulations but stated that they did "not apply to farmers who [could] kill wild animals on their property because they were threatening to destroy their crops."

To oversee such policies the law established a wildife office within the ministry of agriculture. It also created a five-member National wildlife Protector Committee that would make recommendations to MAG, study MAG's abilities to regulate wildIife, and serve as a general advisory board. The committee, however, seemed lopsided and padded; three members represented hunting and fishing organizations*, one was a government fiscal agent, and only one was a biologist from the University of Costa 24 Rica (UCR).

As could be expected, the law prompted intensive lobbying and spirited debate on both sides of the issue. Hunting and sporting organizations argued for its support and humane society members lobbied against the law when it was being considered by the Legislative Assembly in 1961. Opponents argued that the Protector Committee was too much like the fox guarding the hen-

* The three sporting groups represented on the committee were the National Association of Hunters, the Amateur Fishing Club, and the National Federation of Hunting, Fishing, and Shooting. 
25

house. Nonetheless, the bill became law and changed very little even with revisions in 1970 (Law no. 4551).

Other attention was given to wildlife issues in the 1970's when the Costa Rican legislature endorsed international treaties regarding threatened or endangered species. Law no. 5605 of 1974 ratified the Convention on International Trade in Endangered Species (CITES) which established a system of trade sanctions and a worldwide reporting network to reduce the traffic in threatened wildlife. And two years later on a more regional level the Legislative Assembly passed Law no. 3763 which ratified the Convention for the Protection of Flora, Fauna, and Places of Natural Scenic Beauty in the Countries of the Americas. That convention specifically outlined how national parks and reserves should be estab26 lished and guarded for wildlife protection.

To evaluate the country's policies for the protection of native flora and fauna and eventually to recommend changes in the Wildlife Conservation Law, the government sponsored a week-long wildlife symposium in 1980. Called the First National Congress on Wildlife Conservation, the event was organized by the Biological Studies Department of MAG and the National Wildife Protector Committee. Presiding over the congress were Hernán Fonseca (MAG), Gerardo Budowski (CATIE), and Augustín Rodríguez (ICE). Participating organizations included the hunting and sporting Clubs, CITES authorities from Costa Rica's U.N. office, the Association of Costa Rican Biologists, CATIE, several colleges and 
universities, the tourism council (ICT), and two environmental groups. President Rodrigo Carazo gave one of the opening addresses and speakers and presenters represented a virtual "who's who" in national conservation activism. Participants included Alexander Skutch, Gary Stiles, Archie Carr, Joseph Tosi, Mario Boza, and Alfonso Mata. Many of the presenters were leading proponents in the development of Costa Rica's national park system, among whom were Alexander Bonilla (a geographer and environmental activist), Roger Morales (a CATIE naturalist), José María Rodríguez (national parks director at the time), Sergio Salas (an ICT biologist), Carlos Valerio (a noted UCR zoologist), Murray Silberman (President Carazo's environmental counsel), Christopher Vaughn (a professor of wildlife conservation at the National University), Eduardo Bravo (fisheries and wildlife director for MAG), and many other biologists and conservation leaders.

One of the outcomes of the symposium was the revised Wildlife Conservation Law of 1983 (Law no. 6919, and further revised in 1990 and in 1992). The new policy eliminated much of the "public utility" language of wildlife as a natural resource and concentrated more on protecting threatened species. Gone was the language allowing farmers to hunt at will and in its place were stronger hunting regulations. The National Wildlife Protector Committee was also modified to include only two representatives from sportsman organizations (one from hunting associations and one from sport fishing groups). And, most importantly, provisions were built into the law to establish certain national 
wildlife refuges.

Many conservationists in Costa Rica had come to understand all too well that protecting the nation's wildlife meant protecting habitat and ecosystems. In the late 1950's, for example, forest ecologists Luis Fournier and Gerardo Budowski had begun reforestation research projects in the Central Pacific and Atlantic regions of the country. Their aim was to recuperate the tropical forest ecosystems by ways of natural regeneration.

But at the same time, the forests were being increasingly threatened with the influx of squatter farmers and their families seeking new lands to clear and farm. Part of the reason this occurred was because of the advance of large-scale coffee and banana plantations in the late nineteenth and early twentieth centuries which signalled a rapid change in the concentration of land ownership. James Rowles, an authority on Costa Rican agrarian reform, explains that

According to popular mythology, Costa Rica is a country of small land-holders in which phenomena such as latifundismo amd minifundismo, so common in neighboring countries and the rest of Latin America, simply do not exist. . . The facts, however, tell a different story. For while Costa Rica was originally made up of small farmers who dealt with each other on an egalitarian basis, patterns of land tenure have changed drastically since those early days. (29)

Changes in land ownership and rises in population meant that thousands of rural Costa Ricans sought out tierras baldías (vacant lands) that were owned by the state. Aware that the problem was getting out of hand as far back as 1942, the Legislative Assembly 
passed the Squatter Law (Law No. 88, the Ley de Parásitos or Ley de Poseedores en Precario) which sought to halt squatter settlements on government land.

But the solution became part of the problem and actually exacerbated the exploitation of public lands. Professor Rowles notes that corruption and abuses of the Squatter Law resulted in how large landholders

exchanged lands occupied by squatters (whom they often incited to invade) for virgin state lands. The abuse was in the appraisal of the lands that were exchanged, the original holding being overvalued while the state lands were valued at a small fraction of their value. Huge latifundios were created as a result of the misapplication of this law. (30)

The corruption illustrates how squatters were really more of a symptom of the larger problem of inequitable land distribution--a concern that did not go unnoticed by Jose Figueres and the revolutionary movement of the Second Republic. In fact, as Rowles points out, Squatter Law abuses "had a great deal to do with [the Figueres junta's] desire to reform existing agrarian legislation" and became part of "the political ideology that guided the dominant Partido Nacional de Liberacion (PLN) since the Revolu31 tion." A key member of the early PLN was the junta's Minister of Agriculture, Bruce Masis, who was a strong proponent of agrarian reform and conservation. Masis led the efforts to eliminate the squatter Law and to replace it with a land reform bill. The junta thus named a commission to study the problem and to draft a new agrarian code. 
But reform legislation was slow in the making. José Figueres never made it a priority during the junta years (1948-49) and the special commission never even met. Reform plans moved slowly through the legislative process during the otilio Ulate administration (1949-53), with a special commission again appointed to study the issue. Called the Committee on Agriculture and Colonies, it finally drafted reform legislation in 1953--only to be interrupted by the national election which gave Jose Figueres a landslide victory and second term (1953-58). Figueres had promised that the government would create a special institute to deal with lands and colonizations and named yet another committee to draft such a law. Committee members included Bruce Masís, who had returned as Minister of Agriculture and had renewed his campaign for agrarian reform, and Alvaro Rojas Espinoza, the agricultural engineer who also had designed the Soil and Water Conservation Law that same year. The bill the committee drafted, however, was stalled by Figueres who had cooled on the initiative and who now was devoting his energies to establish the electricity commission (ICE) and a federal housing authority.

By 1955, and only because of Masís' perseverence, the commission's proposal to establish a government institute for lands and colonizations finally made it to a committee of the Legislative Assembly. Testifying on behalf of the proposal which would eliminate the Squatter Law and create the land reform institute, Masis argued that

because of circumstances known by everyone [the 
Squatter Law] did not fulfill its commitment to end the so-called problem of squatters in a permanent manner--and which on the contrary, served in many cases as the instrument in realizing scandalous deals of collusion with obvious prejudice to the interests of the country. . . . [S]olutions have been sought for the different cases existing between owners and squatters. Payment shall be made to the owners in bonds and other securities of the state; but it shall no longer be made, as was done in the past, with virgin state lands, so that our National Reserves may thus be saved. (32)

Political maneuvering by the opposition party which opposed the bill prevented its passage in the mid-1950's and delayed the law until 1961. But finally after years of executive commissions and legislative committees Law No. 2825, the Ley de Tierras $y$ Colonizaciones (Law of Lands and Colonizations), was approved by the Assembly and signed by President Mario Echandi. It has been amended and revised eight times since but its purpose has remained the same: to administer agricultural colonization through its administrative agency ITCO (Institute of Land and Colonization). Whether this goal has been successfully achieved, however, remains to be seen. In its first ten years of implementation (1962-1972), 3.7 percent of rural families $(n=7,174)$ received ITCO benefits and they mainly in the form of attaining the legal rights to land they had already been occupying. Only 1,525 families benefitted from the redistribution of 98,400 acres of land. Likewise, ITCO was only able to resolve forty-three percent of the squatter conflicts (involving 75,600 acres) presented to it during that decade. And in the $1970^{\prime} \mathrm{s}$ and $80^{\prime} \mathrm{s}$ the incidence of squatting (or precarismo) accelerated beyond the 
point that ITCO could properly keep up with.

The law and its results are important to consider here for the effects they have had on conservation efforts in costa Rica. First, the law was designed to "contribute to the more just distribution of wealth" in Costa Rica by "avoiding the concentration of national lands in the hands of those who would use them for specialization against the general interests of the nation." Its aim was to "guarantee the economic welfare, liberty, and dignity" of the colonizing farmers which in turn would do the same or the nation as a whole. It provided for the development of agricultural cooperatives, the authority to parcel and distribute lands, the creation of regulations to curb conflicts between precaristas (squatters) and land owners, and the establishment of an agency to provide agricultural credit--especially to those costa Ricans wanting to go into private farming for the first time and who would practice "rational exploitation" of the land. Public lands to be parcelled out for agricultural homesteading would first be carefully surveyed by Costa Rica's Geographic Institute. More importantly, the law delineated which areas of the country were not open for agricultural colonization. It established the authority "to determine what land should not be exploited by agricultural workers" and crystallized government policy to acquire and expropriate "those lands that were not fulfilling any social function" (read: being used for agriculture). Oddly, the bill named these lands "state Agricultural Properties" even 
though they consisted primarily of volcanoes and other lands unsuitable for cultivation. Later amendments to the law added riverways, islands, and watersheds vital for the nation's hydrologic needs. None of these "national reserves" could be colonized, fenced, plowed, be used for any construction, or be used to cut wood. And the law made very clear that any and all lands not under title of private ownership legally belonged to the state. ITCO (whose name was later changed to the IDA, Instituto de Desarrollo Agrario [Institute of Agrarian Development]) monitored the regulation and enforcement of colonization policies. As a benefit to conservation efforts, the agency was staffed with personnel from MAG's Lands and Forestry Department including four engineers trained in forestry from CATIE. Likewise, it was entrusted with the designation and development of nature reserves.

The first such reserve to be created was in 1965 at Cabo Blanco on the southernmost end of the Nicoya Peninsula in northwest Costa Rica. But instead of being initiated by ITCO, Cabo Blanco was the unlikely result of the efforts of a Scandinavian couple who resided in the area. Olof wessberg, a retired officer in the Swedish Air Force, and his Danish wife Karen Mogensen had moved to the Nicoya Peninsula in 1955 to live a simpler life and to raise a sustainable fruit orchard. Their story has been told in detail elsewhere but merits attention here as a vital compon36 ent in Costa Rica's conservation history.

Acting on a life-long dream to leave the cold of northern Europe and to live in tropical America, Wessberg and Mogensen 
left Sweden to work on a farm in Ecuador. They later moved to Guatemala, California, and Mexico but never felt that those places satisfactorily suited them. Then, based largely on a dream Karen Mogensen had one night, they decided to move to Costa Rica. After visiting several parts of the country, they settled at Montezuma at the southern end of Nicoya, bought land overlooking the gulf, and spent the next ten years raising over thirty varieties of fruits and coming intimately to know the flora and fauna of the region. Bill weinberg, a journalist who became acquainted with Mogensen in the late 1980 's, wrote that the couple "Iived a life of vegetarianism and [had] a reverence for nature that bordered on the mystical, taking great joy in the company of monkeys and coatimundis."

The idyllic little world of Wessberg and Mogensen started to change very rapidly in the late 1950 's, however, when larger and larger patches of cleared areas started to appear in the forests across the peninsula. They watched as hundreds of squatters moved into the region, cleared land for crops, and then sold out to lumber and cattle companies when the tropical rains eroded the cropland. Worried that the last remnant of forest habitat of their beloved animal friends would completely disappear, Wessberg contacted some wealthy acquaintances of theirs in California and requested that they purchase the land to be protected as a wildlife refuge. The friends declined but told wessberg that he should contact international conservation organizations which might take up the cause. Acting on a late-night impulse, then, 
Wessberg wrote an appeal and sent it to various groups. He related how jaguars and tapirs were already extinct in the area and that rapid habitat loss was endangering the populations of ocelots, pumas, deer, peccaries, agoutis, coatimundis, and several species of monkeys on the peninsula. "When we settled here six years ago the mountain was always green," Wessberg lamented in his appeal, "today it has great brown patches, and in March and April it is shrouded in smoke, much of it on fire. . . Two 38 years more, and the mountain will be dead." In 1961 his appeal appeared in the magazine of the World League Against Vivisection and for the Protection of Animals.

Donations for the purchase of Cabo Blanco soon materialized. The British World League Against Vivisection contributed fiftyone percent of the funds needed and other money came from the Sierra Club, The Nature Conservancy, the Friends of Nature, and the Philadelphia Conservation League. The environmental groups, however, preferred to give their contributions to a government agency responsible for the conservation of the area. But the only Costa Rican agency empowered to expropriate land for such purposes at this time was ITCO which had no experience in managing preserves. ITCO "was interested in helping farmers to get more land to clear--the opposite of what we wanted," complained Ms. Mogensen in an interview to David Rains Wallace, "they never did understand what it was all about."

Three years later and after over twenty trips made by wessberg to San José to deal with government officials who would not 
answer his letters, ITCO finally expropriated the land at Cabo Blanco and created a reserva biológica absoluta--the country's first nature reserve. In that time, however, more colonizers had moved into the area, and, upon hearing that the land might be expropriated, cut down more trees to "improve" the land by making it more suitable for crops. Mogensen recalled that "a lot of people here really didn't understand what the land was being expropriated for."

The next problem that wessberg had to confront was in guarding Cabo Blanco. ITCO hired only one warden to monitor the entire reserve, who, according to Mogensen, "was a big drinker." He also attempted to make a little extra money on the side by killing the last ten grey spider monkeys--found nowhere else in the world--for the oil in their fat that supposedly had medicinal qualities. Wessberg had him fired. Another warden felled trees inside the reserve to plant crops. After a few more journeys to San José to complain about these problems, the government allowed Wessberg to develop his own questionnaire to screen prospective wardens. The system he used proved so helpful that by the early 1970's (when a national park service had been established), officials offered him an agency position there. He declined on the grounds that he had no desire to move to San José. Wessberg's last campaign for conservation in the Nicoya Peninsula came in the early $1970^{\prime}$ s when he lobbied for establishing an additional reserve around the town of Montezuma. He solicited funds $(\$ 500,000)$ from the International Union for the Conserva- 
tion of Nature (IUCN) in Switzerland. Gerardo Budowski of Costa Rica was the Director General of IUCN in those years but was forced to refuse Wessberg's request because it asked for "way too much money." He urged Wessberg to seek government approval and to have the University of Costa Rica and the OTS conduct feasibility studies on the project before the IUCN could consider

\section{2}

such a request. The project never materialized.

While Cabo Blanco became Costa Rica's first nature reserve in 1965, the next year marked the creation of the first national monument. The purpose in creating Santa Rosa National Monument, located on the Santa Elena Peninsula in the far northwestern corner of the country in Guanacaste province, however, was more as a means to preserve and tout the historical value of the area than as a measure to protect the tropical dry forest in which it was located. Santa Rosa had been a large working cattle ranch but it was also the place where a volunteer Costa Rican brigade had defeated William Walker and his invading band of American filibusters in 1856. Walker, who entertained grandiose notions of establishing his own personal empire in Central America complete with slavery (which had been abolished in the region for over a hundred years) and English (along with Spanish) as the official language, was pushed back into Nicaragua never to set foot on Costa Rican soil again. Thus the Battle of Santa Rosa had become a source of national identity and pride (as well as an important national holiday) for many costa Ricans and especially for Guan-

\section{3}

acastecans. The large hacienda (la Casona) near where the battle 
was staged survived as a monument to this important historic event. (See Figure 2.)

But Santa Rosa was "invaded" again in the 1930 's when Nicaraguan strongman Anastasio Somoza García bought the hacienda as a personal ranch and investment. Never popular with democratic Costa Ricans, Somoza's presence outraged Ticos who over the years pressured the government to oust the dictator from the area. But it was not until 1966 when the Legislative Assembly finally voted to expropriate three thousand acres of Somoza's land surrounding la Casona and directed ICT (the costa Rican tourism institute) to manage it as a national monument.

Seeing the historic and touristic value in preserving this part of Costa Rica' national heritage, ICT welcomed the opportunFigure 2: La Casona at Santa Rosa

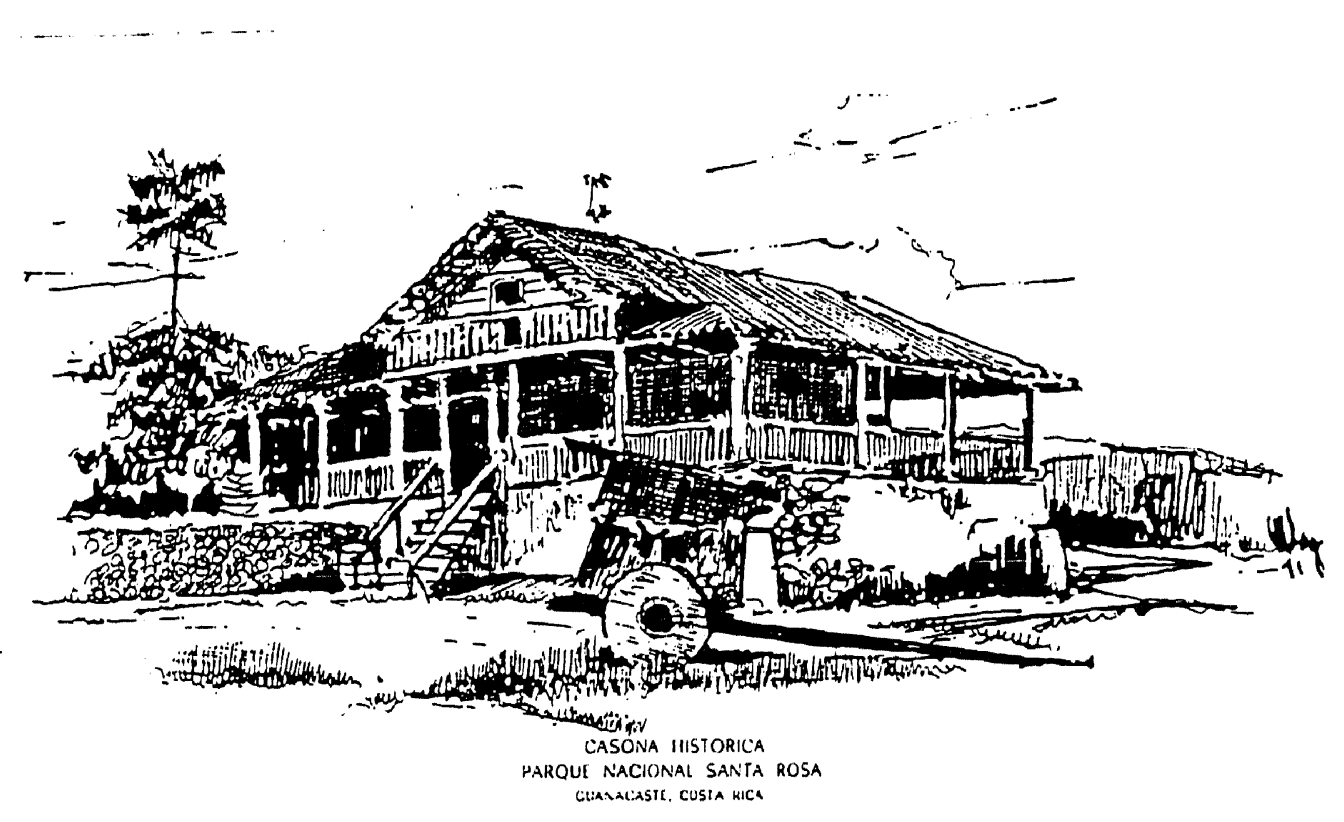

(Source: National Archives, series: SPN, file no. 19) 
ity and hired Kenton Miller, a CATIE parks planning specialist, as a consultant for the project. But Miller recognized that the tropical dry forest in which santa Rosa was located (among the very last remnants of this ecosystem anywhere in the world) was being threatened by slash and burn agriculture and the expansion of livestock pastures. Thus the chance to extend protection over a larger area loomed very large for Miller and he recommended that the government buy thirty thousand acres of the fragile environment to be developed into a park. ICT backed the plan and the government eventually paid somoza roughly $\$ 500,000$ for the land. In 1971 the status of Santa Rosa changed from national monument to national park--making it one of Costa Rica's first 44

such designated areas. National park status, however, was only made possible by the passage of the Forestry Law of 1969, the history of which is vital for understanding the subsequent history of conservation in Costa Rica.

\section{Legislating Protection: The Ley Forestal}

Participants in, and students of, Costa Rican environmental policy making agree that the Forestry Law of 1969 was the key to future conservation successes. Called the "principal milestone," the "transcendental step," and the "turning point" in the country's conservation history, the Forestry Law's impact on the rational use of forest resources cannot be underestimated. Yet missing in the literature is any explanation on the history and career of the law, the mechanics behind its enactment, public re- 
action to its passage, and the changes it has undergone in the late twentieth century.

With the creation of Cabo Blanco Nature Reserve and Santa Rosa National Monument in the mid-1960's, concern developed in certain sectors of the government regarding the lack of comprehensive guidelines to administer protected areas and to conserve other forest resources. One official who was keenly aware of the problem and who worried about the impact of unregulated deforestation was Guillermo Yglesias, Minister of Agriculture and Livestock (MAG) in the administration of President José Joaquin Trejos (1966-1970). In 1967 Yglesias named an interdisciplinary committee to research the problem and to prepare a draft forestry legislation proposal. Heading the commission was stalwart conservationist Alvaro Rojas Espinoza who had had successful experience in organizing and seeing to fruition the 1953 soil and Water Conservation Law and the 1961 Lands and Colonization Law. Representing government agencies on the commission were members from the Ministry of Industry and Commerce, the National Committee for the Conservation of Natural Resources (dominated by the hunting and fishing organizations as outlined in the 1961 Wildlife Conservation Law), the electricity institute (ICE), and the Lands and Colonizations Institute (ITCO). From the private sector were representatives from the Agriculture and Stockgrowers Association and from the Wood Industries Association. And representing the University of Costa Rica was forest ecologist Luis Fournier whom Yglesias stated had "an enormous understanding of 
forestry management." Professor Fournier later remembered, however, that he felt like "un golondrino solo" (a lone swallow) on the commission because of his more active position for environmen46

tal protection.

The special commission worked for nearly a year on the proposal. During that time the members consulted the forestry laws of Venezuela, Mexico, and the United States and hired forestry consultant Nestor Altuve to help draft the legislation. Altuve was a Venezuelan forestry specialist who had helped pass protective legislation in his home country, had been chief of the venezuelan forestry service, and at this time was employed as a sylviculturist with the UN's Food and Agriculture Organization (FAO) in Rome. On 14 June 1968 Guillermo Yglesias sent the commission's proposal to the Legislative Assembly. In an accompanying letter, Yglesias explained that the proposed legislation was "for the defense, conservation, and safer exploitation of our renewable natural resources." He asserted that the country had "been waiting over seventy years" for such a policy and that ever since Law No. 36 of 1906 (which authorized the executive branch to create national forestry guidelines) there had been many initiatives and orders but nothing that had ever become a concrete 47 national law.

What the commission's proposal called for, then, was the legal sanction for the state "to ensure the protection, conservation, . . and development of the country's forest resources . . ." To that end, the law would establish a General Forestry 
Directorate (DGF) within the MAG to "administer the forest patrimony" and "to provide technical support to the wood products industry." Additional MAG duties would include creating protector zones, working to conserve wildlife, combatting soil erosion, controlling forest exploitation, and providing forestry education. To advise on such issues, the law would create a Forestry Council with members selected from the various government agencies involved with land and resource issues. The law would outline regulations for the felling, transporting, and marketing of timber from the country's forests and would establish penalties (stiff fines and jail terms) for policy infractions. It mandated that there be no livestock grazing on public lands without the approval (written permits) of the DGF. And, vital for the more organized designation and management of protected areas, the law would define and provide for the creation of a system of national parks to be administered by the DGF. Lands defined as national parks, forest reserves, and protector zones would be off limits for agricultural colonizations.

In trying to sell such a proposal to members of the Legislative Assembly, Yglesias stressed the economic benefits that would accrue from the bill's approval. After all, much of the bill's intent was directed toward the concept of "multiple use" and was similar in many ways to the public lands management language of U.S. conservation policy. Article one, for example, suggested that the law would be for protecting and conserving the forests, but also for their "exploitation . . and development. . . in 
accordance with the principle of multiple use of renewable nat49

ural resources." Thus, Yglesias noted that the law would "assure the best exploitation of the forests for the benefit of a more dynamic economic development of the agricultural sector." He argued that because of Costa Rica's high rainfall and due to its mountainous topography, protecting the forests, and therefore the soils, would be "one of the most promising economic activities" that the nation could undertake. "The devastation of the forests," he continued, "has produced.. . serious and enduring harms that have restrained the economic development of [certain] communities." And protecting the forests would "stimulate the creation of a stable wood products industry." In conclusion, he reiterated how "the intervention of the state in the administration of the forests.. . would be a benefit for all Costa Ricans." The state could be a "powerful influence in stopping the massive destruction of the forests which harshly changes the meteorologic conditions with catastrophic results and creates adverse conditions for the comfortable life of man." As per Costa Rican legislative procedure, the proposed law was sent to committee before being debated in the Assembly as a whole. It went to the Permanent Commission on Government and Administration where proceedings opened on 19 August 1968. Guillermo Yglesias was called on to introduce the proposal. "There has been a general anxiety among Costa Ricans," he began, "about putting order and regulation to the irrational exploitation that our forests are undergoing at this time." He then as- 
serted that "in reality, if we continue in the steps we are now taking, within a few short years Costa Rica will not have any wood, we will not have any forests to exploit." He went on to point out that

the principal goal of the law is to ensure rational exploitation. . . [But] this is nothing new; the forests of Canada and the United States have been exploited for hundreds of years and they have retained the same value that they had one hundred years ago. What would happen, for example, in countries like Finland where [the people] practically live from their forests, if this [Costa Rican] type of exploitation existed there? Well, the forests would have been eliminated. . . . Imagine that Law 36 of . . . 1906 obligated the Executive Power to send the Legislative Assembly a proposed law--that is to say that as far back as 1906 people were concerned [about the forests], and from then until now we still do not have a forestry law. It is frankly an inconceivable thing. (51)

Yglesias stressed that supplying guards in the forests (a strong FAO recommendation) was one method to start counteracting abusive forest practices. He cited the example of a U.S. logging company in the osa Peninsula of southern Costa Rica that "was exploiting the forest for one use only: permanent damage" and explained that with forest guards, the law "would regulate such abuse." And when one Commission member asked him why the Executive office could not just authorize the appointment of forest guards without going through all the legislative process of passing a law, Yglesias responded that that was impossible without the legal authority of a law on the books, and that "while it seems like a lie, Costa Rica is one of the few countries that has no such forestry policy." "I expect enormous reaction from the woodcutters," he admitted, "and from the people who are taking ad- 
vantage of the forests... . [and] are making lots of money from it, because this law will end that."

When the legislative commission next met to consider the Forestry Law on 21 August, the members heard from Dr. Luis Fournier and others on the proposal team. Fournier minced no words: "You're becoming more aware of irrational forest exploitation. . . [Even] a superficial land analysis of Costa Rica shows that only fifty percent [of the country] remains in forest." And he stressed how the inconsistent and rivalrous nature of having five or six government agencies involved with different aspects of land management was leading to the "atomization" and "anarchy" of conservation policy. The Commission chairman Carlos José Gutierrez agreed with Fournier but asked him to explain how private lands could be acquired for State conservation efforts. Fournier replied that most of the land that would be ceded was not conducive for agriculture or grazing and that there would be "good incentives" and "stimulants like tax reliefs" to encourage landowners to cooperate. Another member agreed with those ideas but argued that banks should bear some responsibility by providing loans for conservation areas just as they would for agricultural enterprises. Returning to the question of enforcement, Chairman Gutiérrez wondered how many forest guards would need to be hired. Fournier responded that his committee estimated that 300 forest guards (guardabosgues) and twenty-five support staff would 53 be needed.

Written statements were also entered into the record during 
the 21 August session and others that followed. A letter from the Costa Rican Attorney General's office gave notice that the proposal was within legal boundaries and that "it was simple, flexible, and long-lasting" and that it would become "the legal instrument to establish the basic objectives of the state's forest policy." Another document entered was a thirty-four page review of the proposal by internationally acclaimed agronomy engineer and forestry specialist Arturo Trejos Núñez (a past consultant on conservation issues in Mexico and Venezuela and author of over seventy articles on renewable natural resources). Proclaiming that the "forest situation" in Costa Rica was "so grave and so alarming," Trejos warmly endorsed the proposal. "Nothing authorizes us to destroy the natural heritage for future generations," he cautioned, therefore the country's resources "should be administered with honor."

In order to gauge regional reaction to the proposed bill, the legislative commission solicited responses from municipalities around the country. Many municipal leaders and town councils mailed or wired in straw votes taken on the bill and most were favorable in nature. Typical of many was the response from the municipality of San Pablo Turrubares stating that the law would give nothing but benefits for future generations. It is an injection of fresh air in the continual fight for a better and more fertile costa Rica. . . The natural resources are a source of incalcuable value . . [and are] an inmense treasure. (55)

Statements of support also came in from the office of the Minister of Industry and Commerce and from international ex- 
perts in the conservation field. But much of the support came in the form of backing the proposal for its economic benefits. Dr. Herster Barres, a forestry official with the FAO, testified that Costa Rica's population was estimated to double by 1988 (it nearly did) and that well-managed forests would mean that more paper products and books would be available for the people. He also stressed that Costa Rica's economy would benefit from such paper-hungry giants as Europe and Japan as their demand for pulp would increase over the years. And even Arturo Trejos (in a testimony preceding his lengthy written review) spoke at length about wood processing technologies and the benefits of keeping the forests in MAG's domain as wood was a harvestable commodity. Likewise, there was strong opposition to the proposal. Conflict developed around the duties of the colonization institute (ITCO) and the tourism council (ICT) in distributing or managing government lands. The problem was in the identification and designation of "lands not suitable for agriculture" which ITCO was often in the habit of distributing and which conservationists believed should be protected. Under the new forestry law such lands could fall into preservation categories which officials at ITCO believed should only be in their jurisdiction to determine and officials at ICT believed should only be in their jurisdiction to designate and manage. In a letter to the legislative commission, ICT director Ricardo Castro wrote that his agency was "not in agreement" with the proposal's policy of shifting to the agriculture ministry (MAG) the responsibility to establish pro- 
tected areas. He argued that the law that created ICT in the mid1950 's "authorized [it] to declare which zones [would become]

national parks" and that Santa Rosa National Monument was in its 57

"custody" and being managed just fine.

And, as would be expected, opposition came from certain private sectors who stood to lose from the forestry law. The Costa Rican Construction Association, for example, lobbied against the proposal. The association's president Luis Manuel Chacón wrote the legislative committee chairman explaining that while his group supported "the idea of permanent forest reserves.. . for the defense of our forest resources," it was in "absolute disagreement" with the tax the law would levy $(6.33$ colones) on every 58 cubic meter of wood cut.

Opposition notwithstanding, the Permanent Commission on Government and Administration unanimously approved the proposed forestry law and sent it to the Legislative Assembly on 29 April 1969. It had been in committee for ten months and lasted in the Assembly as a whole for seven more. During that time the legislature received an unprecedented outpouring of petitions, letters, and telegrams from various sectors of the country in support of a national conservation policy. A twenty-two page petition, for example, was sent from students of the Coto Brus and Osa Agricultural College in southern Costa Rica urging members of the legislature to pass the law. The students declared that they "could not continue celebrating the National week for Natural Resources if the forests, waters, soils, wildlife, and places of scenic 
beauty continue to be subjected to increasingly more intensive destruction." And the president of the prestigious Association of Biologists (Colegio de Biólogos) of Costa Rica sent notice to the Assembly that his organization was in complete support of the 59 measure.

School children across the country also sent many letters and telegrams to the Legislative Assembly urging members to vote for the proposal to protect forests and natural resources. Indicative of many was a telegram from the high school students of the Liceo Rodrigo Facio who stated, "we desire a better future for us via a forestry law that will also raise the economy of our beloved Costa Rica." Others wrote in supporting the law as a means to preserve the woods, the animals, and the birds that 60 represented the country's natural heritage.

The media had a less active role in supporting the cause but one large San José newspaper, La Prensa Libre, openly campaigned for its approval. In a long editorial published on the day the bill was to come up for a vote (25 November 1969), the paper endorsed the law and urged Assembly members to support it. Praising the measure as "an important legal instrument" and "of major importance for the economy of the nation," the editorial protested the past "exploitation of the forests [that occurred] without any controlling action" and stated that the new law would "protect the forest heritage for the people of Costa Rica." It argued that the law would be the only way "to stop the axe from continuing its destructive work" and the only hope "to save [our] 
natural reources for future generations." It mentioned that forest "production" should be considered on equal terms with the production of rice, beans, and corn, and that forest protection was "indispensable" for maintaining potable water sources, construction materials, and other "extremely helpful" uses for humans. And finally the editorial called for strict enforcement and penalties for infractions of the law "because to continue tolerating the irrational exploitation of our forests, like we have tolerated in the past. . would nullify the law with visible damage to the country."

Opponents were against the law for a variety of reasons. ITCO sent word to the Assembly members that more time was needed for its attorneys to study the proposal as it applied to how it would affect land colonization efforts. Private citizens wrote against the measure on the grounds that the government had no business setting aside certain areas of land. Representative of these individuals was Rodrigo Salas Retana from Guadalupe who noted that

it's not like Costa Rica is a big country like the United states. We do not have that much private land; we are not big enough for this, even though [many people] just see San José and think we're huge. . . .

He went on to suggest that it was "risky" for the government to become involved in issues of land management, especially compared to "us [land-owners] who have known and continue to know that in repeated periods they [the government agencies] have become owners of thousands of hectares of our valuable, unculti- 
vated national lands." And he brought up important concerns like who the parks and forest guards would be, how they would be paid, whether they would be able to "complete their mission," and how they would be monitored, especially in light of how they might be "paid off" to abandon their guard. Important questions like those, he argued, were unaddressed in the proposal and caused him 62 to oppose it.

Assembly members reflected such constituent concerns by raissing similar questions in floor debates and by sponsoring many motions and amendments to the bill. The Assembly even named another committee to study some of these motions and how they could be incorporated into the law. Committee debates and dickering on legislative rules and procedures took up most of September and October, but finally on 21 October 1969 the proposal returned to the plenary session. Most speeches presented there were in favor of the law. One diputado argued that the law would take nothing away from farmers but rather would protect lands for their children. "I'm voting for the law," he affirmed, to save our national resources from total destruction." Another member reiterated the arguable point that Costa Rica was the last Latin American nation without a forestry law and that there 63 should have been one on the books since 1906.

The opposition by this time was concentrated on defending ITCO policies and land reform in general. Some members believed that ITCO was being "unfairly attacked" as the enemy of conservation. Others thought that land distribution could coincide with 
conservation policies. Diputado Volio Jiménez pointed out that even delegates to the 1966 world Conference on Agrarian Reform in Rome concluded that conservation of natural resources should go 64

hand in hand with land reform. But the opposition was the minority opinion in the Assembly, and on 25 November 1969 the plenary session of the Legislative Assembly passed Law No. 4465 the Ley Forestal. *

Public reaction to the creation of the framework that would protect Costa Rica's forests and establish national parks was modest at best. The forestry law came to a vote when the Assembly found itself, as one newspaper put it, "in the biggest of squeezes"--when it had "never been in such a tight spot with so 65

much pending legislation." Perhaps that was part of the reason that the country's largest newspaper, La Nacion, did not report the law at all on the day it passed and waited two days before ever mentioning it with a small article on page forty-four. The paper's "capitol hill"-style legislation column never did mention the Forestry Law. Bigger legislative news was the debate in the Assembly to finance a sport center in San José. Part of the reason also lies with the breaking news stories of the day with which the new conservation policy had to compete. Newspapers logically gave far more coverage to such national headline events as the tropical storm and flooding that caused a great deal of

* Curiously, the Archives of the Legislative Assembly does not have the register of debate from the final few weeks of the law's consideration, the vote tally, or the register of how each diputado voted. 
destruction in southern Costa Rica and to the José Figueres presidential campaign.

Likewise the media gave much attention to such international topics as the successful landing of Apollo XII, the unravelling of the tragic events surrounding Lt. William Calley and the My Lai Massacre in Viet Nam, anti-war protests and hippies in the United States, the continuing saga of violence between Honduras and El Salvador, and a deal between Anastasio Somoza and Aristotle Onassis regarding the "canalization" of Nicaragua. More surprising was the space given to such headline stories as the re-election of Kenyan president Jomo Kenyatta, the sixth anniversary of the assassination of John F. Kennedy, the Native American occupation of Alcatraz, and the news of Brazilian soccer great Pele's expulsion from a game one day after making his one hundredth goal--all of which received more coverage than the newly passed Forestry Law. Ironically, on the days surrounding the creation of a law to protect forests, La Nación ran large display ads for Steyr Tractors that could "conquer the Costa Rican countryside" and for Volvo logging trucks (called madereros) which were supposedly superior than their competitors for hauling huge logs in the rough mountainous terrain. And even campaign ads for Jose Figueres promised "land for everyone" and acknowledged that "the demand for Iand exists" and that the government had "only started to satisfy it."

The only newspaper to report on the Forestry Law on the day of its approval by the Legislative Assembly was La República in 
a short article on page thirteen. Declaring that the new law "constitutes the most modern and advanced" of policies, it went on to quote Guillermo Yglesias who said he was glad the country "finally had good forestry legislation that will allow us to advance in so many areas." It reported that President José Trejos was planning to sanction the new law. When La Nacion ran an article concerning the law two days later, it quoted President Trejos at the signing ceremony. "The step that has been taken with this law," he began, "is transcendental for the progress of Costa Rica. . [and] means a great deal for the rational exploitation of forest resources."

"Rational" is not always the word that can describe forest use since the passage of the Forestry Law in 1969. As explained earlier, deforestation has left its ugly mark on the Costa Rican landscape--much of which has occurred since the law went into effect. Colonization, or precarista squatting, increased in the $1980^{\prime} \mathrm{s}$ and only recently has slowed to some degree. Logging continues in restricted areas that are inadequately patrolled and the nation's forestry policies are still enforced with insufficient funds and fewer personnel than needed. A green ethic does not yet pervade the business community and is especially absent in the forest extractive industries.

Yet comparatively, one must bear in mind the alternative and ask what directions land use might have followed without the Forestry Law. In that light, then, it becomes easier to see how the law can be viewed as a success in other dimensions of conserva- 
tion. That it provided the vehicle to set aside areas as national parks and biological reserves has been its most successful benchmark. It is to that dimension that we must turn next. But in understanding the career of the law--and it indeed has been a long and multifaceted one with revisions and reforms groaning through the legislative process in 1977, 1980, 1986, 1990, and 1996 (the last of which will be discussed in Chapter 7)--it is clear that it was the initial and most important step of the conservationist response to the environmental problems so besieging the nation by the end of the $1960^{\prime} \mathrm{s}$.

Figure 3: President José Figueres Ferrer

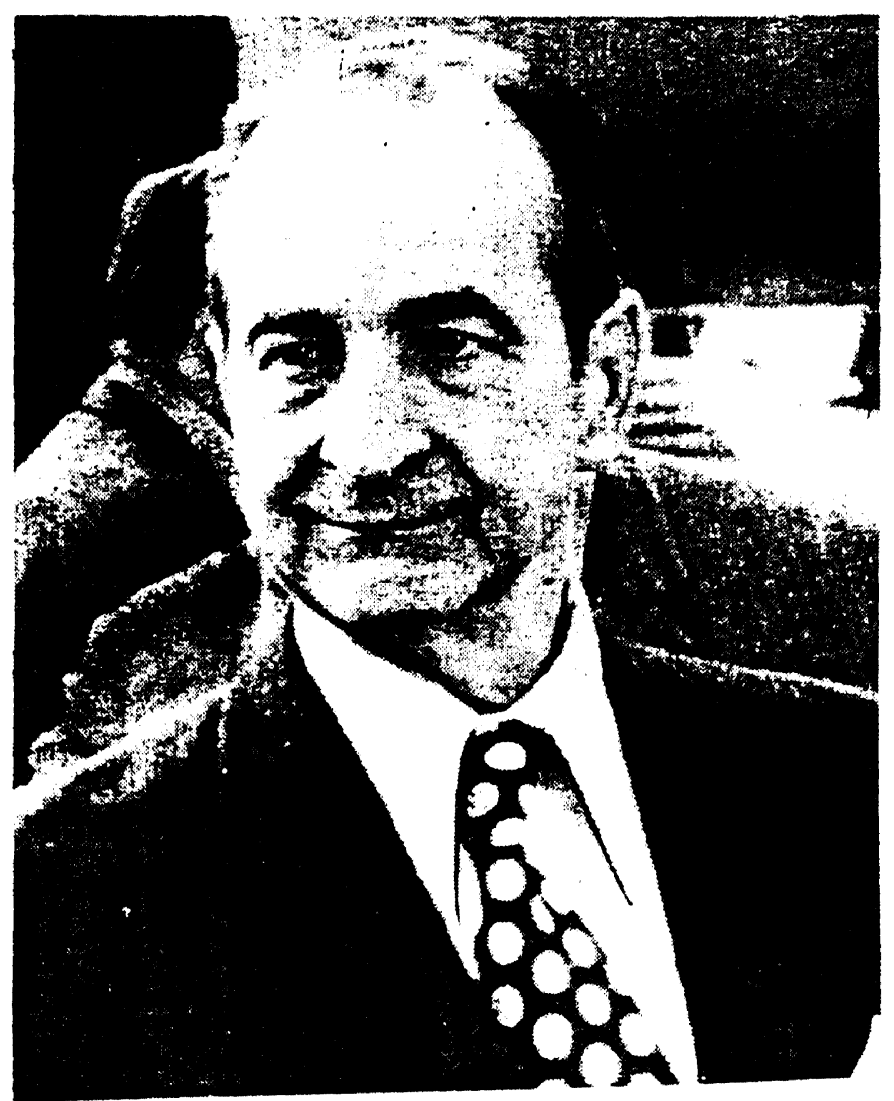

(source: Harold Bonilla, Los presidentes [San Jose: Editorial Texto, Ltda, 1985]) 


\section{CHAPTER 4}

THE DEVELOPMENT OF NATIONAL PARKS AND OTHER PROTECTED AREAS

The Costa Rican national park system gives some hope that the marvelously diverse communities of tropical organisms will be preserved for future generations to enjoy and for future scientists to study.

- L.D. Gómez and J.M. Savage (1)

"A Thousand and One Tricks"

The capstone of Costa Rican conservation policy and indeed the dimension of conservation most known to both Ticos and foreigners is the country's system of national parks and other protected areas. Chapter Six (articles seventy-four through seventyeight) of the 1969 Forestry Law outlined that "national parks" would be created not only for the conservation of flora and fauna (as had been the case with earlier park experiments), but also to offer opportunities for recreation, tourism, and scientific research. Interestingly enough, the decision to designate such areas was granted to the president of the country upon the advice of a National Forestry Council (made up of delegates from several different government agencies and the University of Costa Rica $[\mathrm{UCR}])$. But while many important parks were created this way, executive decree would be a proviso tainted with political undertones during some administrations.

Chapter Six of the Forestry Law was also the instrument that provided for the establishment of a National Parks Department within the General Forestry Directorate (DGF)--a new agency created by the law that was a division of the Ministry of Agri- 
culture and Livestock (MAG)--to oversee the development and management of parks and equivalent reserves. Funding for the DGF and its park service came via the Forestry Fund which the law established to generate budgets and to channel donations to the proper agencies. The law stipulated that additional operating funds would be derived from the costa Rican general revenue. One report that evaluated this program a number of years later concluded that the system was designed to make "the state responsible for ensuring the protection, proper use, conservation, and development" of national parks and "to solve the problems of natural resource misallocation and misuse."

To head the new National Parks Department, the DGF hired Mario A. Boza--a UCR School of Agronomy graduate and recent recipient of a Master's degree in forestry from the Inter-American Institute (later called CATIE) in Turrialba. Boza, who had studied under Gerardo Budowski and Kenton R. Miller and had written his M.A. thesis on a development and management plan for a proposed Poás Volcano National Park, was already working in the planning office of MAG when the Forestry Law created the National Parks Department. The background on why and how Boza became so actively involved in conservation issues and his enthusiasm for national park development made him the logical candidate to take charge of the new parks department.

The origin of Boza's conservationism was his enrollment in Dr. Miller's national parks course in Turrialba. He was directed there by Professor Budowski who had sensed that Boza's initial 
interest in teakwood production was being superseded by an increasing personal commitment to biological preservation. Boza gained from Miller's course and especially from a field trip the class took to visit conservation areas in the United States in 1967. Miller took his students to Florida and Tennessee to visit U.S. national forests and parks and when they arrived at the Great Smoky Mountains National Park, according to one source who met Boza shortly thereafter, "it was love at first sight; he devoted every waking moment to learning about parks." Reminiscing about this baptismal experience later, Boza told another interviewer that "[t]he first time I saw a whole park working was in the Smokies." "I saw the people going back and forth, using the facilities," he recalled, and on seeing "all the things that had grown up around the park because it was there. . I thought Costa Rica was ready for that." Miller remembers the effect the visit had on Boza: "On a free day just outside Great Smoky Mountains National Park, I asked if anyone wanted to go back into the park. . . Boza did, and that evening he turned to me and said 'Is there a possibility that I could change my thesis and study how to develop a real national park for my country?'"

In 1968 Boza attended a one-month international training course in national parks management in Aspen, Colorado. The seminar, entitled the "International short Course on the Administration of National Parks and Equivalent Reserves," was jointly sponsored by the University of Michigan's School of Natural Resources, the U.S. National Park Service (USNPS), and the washing- 
ton, D.C.-based Conservation Foundation. That experience further accelerated his interest in seeing parks established in Costa Rica and assisted him in creating ideas for his M.A. thesis. On Dr. Miller's recommendation, Boza wrote a master plan for Poás Volcano just north of San José. This was a logical place to start thinking about accessible national parks (the Cabo Blanco Nature Reserve had restricted public access) since it was close to a major city and had an all year road to the rim of the volcano. Likewise it was an ideal location for protecting the spectacular cloud forest that surrounded the volcano and that was prime habitat for the resplendent quetzal--an ever threatened species due to regional deforestation. Boza's plan called for facilities similar to ones he had seen in U.S. national parks including a visitor's center, nature trails, interpretive signs, 6 and access to view the crater.

Boza also visited different parts of Costa Rica to become better acquainted with areas that could be considered for conservation. In 1969 he travelled with a group of interested people to Tortuguero to view the marine turtle nesting areas that Archie Carr and his family had been working to protect since the mid1950 's. Tortuguero, on the Caribbean coast of northeastern Costa Rica, is surrounded by lush tropical lowlands and is difficult to get to (even today), thus the group journeyed by bus, train, boat, mule, and foot, having plenty of time to visit and become acquainted with each other in the process. This was an important point for Boza since among those in the party were former Presi- 
dent José Figueres and his family. Figueres was running for an unprecedented (nonconsecutive) third presidential term. (He won later that year and served in office from 1970 to 1974.) His wife, Karen Olsen de Figueres, was deeply interested in conservation issues and especially in national park development for Costa Rica. Also on the trip were Kenton Miller, Gerardo Budowski, and a UCR biology student and avid outdoors enthusiast named Alvaro Ugalde whom Boza had met earlier at a natural resources symposium. Ugalde later returned to Tortuguero with the Figueres's son José María (who twenty-five years later, in 1994, was elected President of Costa Rica!) to spend a month tagging green turtles with the Carrs. Needless to say, the connections forged on the Tortuguero trip were of the utmost importance for all concerned. With a master's degree in hand and his position in planning secured at MAG, Boza next set out to generate public support for the benefits of national park development. In 1969 he wrote editorials to San José newspapers extolling the economic value that tourism to national parks could offer and cited the boon tourism had been to East Africa's economy. Then with the passage of the Forestry Law later that year and when Boza was named chief of the new National Parks Department in 1970, the opportunity opened up to put into action many of the dreams and ideas he had been advocating. Understanding the gravity of his new work, he stated that it was the dangerous environmental brink at which Costa Rica had arrived that spurred the need to act quickly and decisively: "[A] series of environmental problems like deforesta- 
tion, poaching, erosion and pollution seriously threatened the conservation of the cultural and natural heritage of the nation." The creation of the national parks system, he explained, was "to preserve at least representations of this heritage."

Boza's next step was to fortify his department by training others in park planning and management. He definitely needed the help. "The new department was given responsibility for all of Costa Rica's volcanoes, a nature reserve [Cabo Blanco], and the Santa Rosa National Monument," Boza later recalled, "[t]he problem was that it had no budget and only one employee--me." Thus, he contacted Alvaro Ugalde (still a student at UCR) and urged him to attend the one-month national parks training course in the United States. Via funds from Archie Carr's Caribbean Conservation Corporation, Ugalde attended the seminar and ended up staying an extra two months at a different training course held at Grand Canyon National Park in Arizona. When he returned to Costa Rica in 1970, Boza placed him in charge of Santa Rosa National Monument, and then left to complete the training course himself 9 in the United States.

Ugalde recalled that those early years were slim for the new department and that "the Park Service didn't have the money to hire me." Santa Rosa had been "pretty much abandoned by ICT [ the tourism institute] because the Forestry Law said it was to be managed by the park system, and Cabo Blanco was still being managed by the wessbergs, and that was it." He and Boza were confronted with a variety of needs--guards, construction materials, mainten- 
ance supplies, political support for their programs, etc.--and had very few means to attain them. Thus, they learned to be clever. Boza explained how "the idea was to seize any favorable opportunities or circumstances that came up, even unexpectedly, to invent a thousand and one tricks to get what we needed. . . ."

One of the tricks that worked the best was to capitalize on the connections they had made. The value of knowing the right people and being able to seek their assistance became very clear in those early years. The literature is consistent in pointing to one individual in particular, however, as being the most influential for park support: the First Lady of Costa Rica, Karen Olsen de Figueres. Similar to many first ladies in the United States, Doña Karen (as she is affectionately known in Costa Rica) took on a special cause or avocation during her husband's term. The cause she chose was preserving the environment and establishing national parks. Allen Young, an American naturalist who spent a great deal of time in Costa Rica during the embryonic stages of its park development, goes so far as to say that the national park system was "rooted" in the efforts of Mrs. Figueres. Mario Boza has referred to her as "our fairy godmother of conservation." In a presentation he gave at the world Conference on National Parks in 1972, Boza spoke at length regarding Doña Karen's important role:

The best collaborator. . . a park program can have is the First Lady of the Republic. Costa Rica's First Lady Señora Karen de Figueres has not only given her full support to the theme of conserving the natural patrimony of the country, but has gone 
much further by proposing a large scale program-now before the Legislative Assembly--for establishing and funding a system . . . that would comprise no less than sixteen new parks. What was of particular importance to us is that [she] was in the position to give practical help in everything. Through the president, she can get proposals for new legislation, . . . she can ensure the support of the agency heads and legislators belonging to her party, seek certain kinds of international aid which can only be obtained by approach at the presidential level, etc. In short, it was only after Doña Karen began to help us directly that our park program began to make rapid progress.

Likewise, she joined environmental groups and served as a member of several conservation commissions.

What is not discussed in the literature, however, is why Mrs. Figueres became so personally involved. In an interview conducted for research on this study, Doña Karen explained that she became motivated to work on environmental issues out of a religious, "conscious-oriented" calling. "Helping people become conscious of what God has given us, of what brotherhood means . . and of our responsibility as stewards of the land," she remarked, was "so essential to me." Continuing, she stated, "each person's value and responsibility [towards the land] brings unity and balance. - and instills a conscience of who we are in Costa Rica." She also mentioned that her interest in the environment was an extension of her educational and professional background as a sociologist. This discipline had helped her understand how the "development [of a country] is not logical without considering long-range values." "Too much thinking today," she explained, "is short-term or for right now." Born 
in Denmark, raised in the United States, but "one thousand percent Costa Rican" most of her adult life, as she explains it, Doña Karen viewed her role as First Lady to be a catalyst for 13 national park protection.

Other people also offered valuable assistance. Arthur "Tex" Hawkins, for example, volunteered much of his time to help ugalde in Santa Rosa. Hawkins, a U.S. wildlife biologist-journalist who who had been a Peace Corps volunteer with Costa Rica's Fish and Wildlife office, and Ugalde were aware that problems had started to mount in Santa Rosa while Boza was out of the country completing his training with the USNPS. They were concerned that forty families of squatters had moved into the Playa Naranjo area of Santa Rosa, had started to clear it of forest, and had proceeded to set up farms. Likewise, as Ugalde recollects, "one of the rancher neighbors up on the dry forest area of the volcanic plateau had stolen sixty hectares [approximately 150 acres]--just moved his fences sixty hectares into the park." The park had but one workman at the time (and he and other forestry officials were turning a blind eye to the damage), and so, as Ugalde relates,

Tex and I decided to fight for Santa Rosa as volunteers. Mario [Boza] had left the keys of his apartment in Santa Rosa with me, so Tex and I would meet and raise hell from there. We were the park service, and neither of us worked for it. It got very heated.

They also alerted Boza to the problems. When he returned to San Jose he wrote the MAG minister about the destruction and sent copies of his letter to various newspapers to arouse public support. With headlines such as "Santa Rosa in Flames; National 
Park Being Burned" (although it was not yet officially a national park), the government got the message and proceeded to remove the 15

ranchers and to relocate the squatters.

Moving the squatters, however, was no easy task. The job

fell on Ugalde (still an unpaid volunteer) who remembered that

[i]t was very difficult at the beginning because even though I was supposed to be the authority, in reality they were. . . . They were very aggressive at first, with machetes and all that. But I went around the whole park by myself without a gun and started talkin to them. Pretty soon we were having coffee and trying to negotiate. They said, 'Well, if that's official, then we need to get paid for our improvements, and we need land somewhere else, and we need transportation.' I told them I'd get them those things . . . [or] I'd resign. . . . I would have resigned but the government came through, and by July we were actually loading chickens and pigs in cars and taking them away. (16)

The government issued bonds to buy out the squatters and to help finance future park development at Santa Rosa. But the troubles did not end when the squatters left. On the very day that the last family had been successfully removed, Boza and Ugalde learned that there was a bill in the Legislative Assembly aimed at taking Santa Rosa away from the new National Parks Department and returning it to the national tourism institute, ITC. The bill was sponsored by the president of the Assembly, Daniel Oduber, who was a powerful cattle rancher from Guanacaste and who was a friend of the Santa Rosa area rancher who had been illegally running livestock in the park. Oduber's bill, supportted by ICT personnel who had opposed the Forestry Law that transferred Santa Rosa out of their domain, would have opened up the 
park to more grazing by other area ranchers. Ugalde was worried about the precedent such a bill would establish and was reported having said to Boza, "Mario, we [the parks department] are only six months old, and already we are an endangered species."

At that point Boza and Ugalde started a campaign against Oduber's proposal. Noticing that the funding clause for the bill levied a new tax on liquor, the two men actively engaged the business community to lobby against the proposal. They also enlisted the support of the Costa Rican Biologists' Association (Colegio de Biólogos) whose members wrote letters in defense of the parks department and lobbied against the bill. But most importantly, as Boza put it, "we called on our fairy godmother." When told of the situation, Karen olsen de Figueres talked with or wrote every member of the Legislative Assembly and outlined why Oduber's bill should be rejected. According to Boza, she also wrote a personal letter to Oduber requesting him to withdraw the proposal. As the story goes, she showed "considerable political artistry . . . [and] asked her husband--without telling him the contents of the letter--if he would deliver it himself to Oduber." President Figueres handed him the message but oduber refused to relent. Nonetheless, when the Assembly voted not one 19 diputado supported the measure. Its unanimous failure represented a victory for Boza and Ugalde and for the future of the national parks program. It also illustrated the significance of Doña Karen's attention to conservation concerns and was a hallmark for her continued involvement in national parks causes. Santa Rosa 
was officially changed to national park status in March of 1971 and Ugalde was appointed its first salaried administrator two months later. "So the Park Service now had two people," he stated, "or three, if you count Mario's secretary."

A "Towering Responsibility:" The Early Years of Park Development

The first task facing Mario Boza and the National Parks Department was, as Boza put it, to decide "what type of parks. . . [to] create first." He decided to steer a practical course--to concentrate on one or two areas and to make them models for future park development. He related how the idea was "to create parks in areas of stunning beauty, on historic sites commemorating heroic exploits of the past, and in areas of demonstrated importance for conservation." The goal was "to merge historical, scenic, and natural values so that no one could object, making it easy to sell the public on the idea of conservation."

Selling the idea of national parks to the public was no easy chore in 1970. Boza explained that at that particular moment in time Costa Rica was experiencing

intensive deforestation to open new lands for agriculture and cattle raising; chaotic land settlement by campesinos... normally following the course of new highways; active trade in wild animal products; very weak environmental education; total indifference to environmental problems on the part of the general public and decision makers; and a lack of protected wild areas that could provide a model of how to conserve nature. (22)

Working without a model, without any experience, without much funding, and with only "five guards and a vehicle," then, became a 
daunting task. "We found ourselves faced with the towering responsibility of developing a system of national parks and equivalent reserves," Boza remembered, and "we realized immediately how much we needed: staff for administration, protection, and tourist and visitor services; funds to purchase land, buildings, equipment, supplies, uniforms, medicine, and fuel; training for staff; and published materials for interpretation."

But parks they did create. The first area officially to be protected under the new guidelines of the Forestry Law was Cahuita National Monument in September of 1970. Cahuita, which was changed to a national park in 1980, is located on Costa Rica's extreme southeast Caribbean coast and includes tropical forest, miles of pristine beaches, and a 1500 acre coral reef that is the only well-preserved reef on Costa Rica's Caribbean side. That same month a small part of what would in 1975 become Tortuguero National Park (up the coast from Cahuita) was declared protected for marine turtle nesting grounds. In January of 1971, Poás Volcano was declared a "pilot national park" and many parts of Boza's master plan that had been his M.A. thesis were converted into the working management plan for the park. Poás Volcano--a mountain that had been discussed, designated, and labelled with different forms of conservation tags and had been "managed" by several different government agencies since 1939--finally became Costa Rica's first official national park. Two months later, in March of 1971 which happened to be the 115th anniversary of the battle against William Walker and the filibusters, Santa Rosa's 
status was changed from "national monument" to "national park" to 24.

become Costa Rica's second official national park. The executive decree to create the park was signed by President Jose Figueres. (See the map on page seventy-six for exact locations of these parks. )

To celebrate the inauguration of Santa Rosa National Park and to honor the anniversary of the Filibuster war, the parks department decided to host an on-site ribbon cutting ceremony on 20 March 1971--the same date as the famous battle in 1856. According to newspaper accounts, eight thousand people attended the event, including a variety of government dignitaries, local officials, and school children from around Guanacaste province. MAG Minister Fernando Batalla signed the national park proclamation on the steps of the famous Casona. Vice Minister, Alvaro Rojas Espinoza (who had been so instrumental in passing conservation legislation in the $1950^{\prime} \mathrm{s}$ and $60^{\prime} \mathrm{s}$ ), read the first articles of the decree to the audience. President Figueres was unable to attend, but his wife Doña Karen assisted with the ribbon cutting and gave a brief speech. After requesting a moment of silence for the Costa Ricans who had lost their lives in the 1856 battle, Mrs. Figueres asserted that Santa Rosa represented a "symbol for the homeland, a symbol for the future development of Guanacaste, and a symbol for the integration of the entire costa Rican family because it is here that one finds the past, the present, and the future."

Daniel Oduber, the president of the Legislative Assembly who 
had unsuccessfully tried to remove Santa Rosa from the parks department a year earlier, was also on hand to deliver a speech. Making an abrupt about face, Oduber now spoke glowingly about Santa Rosa and directed his remarks to the school children in the audience. He exhorted them to preserve Santa Rosa against "contemporary filibusters." "To you we hand over a united and peaceful country," he began, "assured of the fact that you will defend this sacred land, tree for tree and palm for palm." He also challenged them "to show the world that here in Costa Rica we defend natural resources and the beauty of nature, and that we know how to respect religiously . . . the nature that God has given us."

The United States offered official congratulations to the government of Costa Rica. President Richard Nixon sent a cable to President Figueres saying:

I am pleased to congratulate you and the citizens of Costa Rica on the occasion of the inauguration of Santa Rosa National Park. In an era in which we face great dangers it is particularly opportune that this date. . . of the glorious battle in the defense of your country, also marks the efforts to preserve the rich heritage and resources of your country. We in the United states feel very encouraged by your example. (27)

Secretary of the Interior Rogers C.B. Morton was unable to make the event but he sent USNPS representative Myron Sutton. At the ceremony, Sutton read a letter from Morton who wrote that Santa Rosa's designation was of "immense importance" to the citizens of Costa Rica. "Not only has it saved an historic heritage," he stated, "but it also has rescued from extinction a natural area of inestimable value." In his own words, Sutton told the crowd 
that "the great battle of 1856" could be compared with "the great battle of our days--the conservation of the environment and of 28

the national heritage." Also in attendance were FAO representatives Richard Wilder and Kenton Miller--assuredly gratified at the conservation successes of his former student, Mario Boza.

But while the creation of these initial national parks can be seen as a success, Boza's first year as Parks Department chief was filled with challenges and setbacks. Soon into his position he wrote Gerardo Budowski (then a director at the International Union for the Conservation of Nature [IUCN]) that "I have hundreds of problems that I would like to discuss with you." At Cahuita, for example, land acquisition had been a problem. A former park service attorney explained that "the legal mandate to acquire lands could not be carried out because the Cahuiteños were very obstinate in those days... and the community viewed the creation of the park with distrust." "The government," she continued, finally "reached an agreement with the residents of Cahuita saying that the state would not proceed with any land ex30 propriations until they were satisfied" with the arrangements.

Trouble was also brewing once again in politically besieged Santa Rosa. Official park designation, the act of having a fulltime administrator (Alvaro Ugalde) on site, and a dignitary-laden inauguration ceremony all could not prevent scandal number three from hitting the newly created park. In June of 1971, just three months after the grand opening ceremony, the National Youth Movement and the Biologists' Association complained to San José news- 
papers that Santa Rosa was being overrun by livestock. Trails and picnic areas that the youth organization had helped to build were being severely damaged by cattle grazing in the park. The Colegio de Biólogos estimated that several thousand head of cattle in Santa Rosa had converted the national park into "a virtual ranch."

Worse, it soon became known that the minister of MAG himself (who also was over the National Parks Department) was involved in running cattle in Santa Rosa and had abetted fellow ranchers in the region to graze their cattle there. Complicating matters was the fact that Mario Boza and Alvaro Ugalde knew that their boss was the policy violator and that they were frustrated about not knowing how to handle the scandal. Non-governmental conservation activists like Alexander Bonilla also knew what was going on and were equally perplexed. Just who does one approach to report the 32 agency head's misdeeds?

Enter once again Karen Olsen de Figueres. "This incensed me!," Doña Karen recalled, "and it became the turning point for me to get involved" in this and other environmental causes. "It gave me the green light" to try to make a difference, she stated, and hopefully "gave the green light to like-minded people to get involved." The problem was that MAG director Fernando Batalla was appointed by her husband and claimed that the scandal was the work of a biased, liberal press. He argued (mistakenly) that grazing cattle was part of the management plan of the park. It was not; in fact it was a direct violation of Article 81 of the 
Forestry Law. Thus, she lobbied her husband to act on the violation and worked to expose the problem, even though, as she 33 admitted, "I was conscious it would bring trouble at home."

The courts eventually had the violators remove the livestock. Some of the cattle, however, had to be killed by park employees who distributed the meat to hospitals. When asked about the political ramifications of denouncing this scandal, Mrs. Figueres replied that she "was born to serve... . [and that] political positions do not belong to us, they are only loaned-they are not fulfilled just by getting votes." From that time on, Doña Karen lobbied for national parks, funding, and international assistance on ecological issues. In 1972, for example, she used her position to solicit funds from UNESCO on behalf of the National Parks Department and the Caribbean Conservation Corporation for the on-going marine turtle protection program at 34 Tortuguero.

Twenty years later, Karen Olsen de Figueres was still involved in environmental issues. Her husband's death in 1990 did not deter her from running for an at-large seat in the Legislative Assembly (which she won) and where she continued to be active in environmental policy making. She identified her work there as an effort to attain "consistent" government attention to rational and sustainable use of the country's natural resources. legislation she was working to pass in 1992 concerned preventing the Isla del Coco (Coco Island off the Pacific Coast) from tarnishing its national park status by becoming a casino island for 
which many people with "right now" attitudes and "short-term economic hopes" were pushing. She introduced legislation banning the importation of foreign toxic waste to be dumped in Costa Rica, supported the idea of a Western Hemisphere "green belt" corridor to run from Canada to Chile (which would "cause a political and environmental unity" across the Americas), and advocated that San Lucas Island become a marine research station for the University of costa Rica. In the administration of her son, President José María Figueres (1994-98), Dona Karen retains the office of "itinerant ambassador and counselor" to the president. She remains involved in a variety of social, environmental, and international issues. (35)

Mario Boza and Alvaro Ugalde did not enter the political fray that rocked Santa Rosa with the 1971 cattle crisis and in which Karen Olsen de Figueres was so personally involved. Since one of the perpetrators was their supervisor they logically stayed their distance. Not so, however, when scandal number four hit Santa Rosa one year later. Because a severe drought was adversely affecting agriculture in Guanacaste in the late spring of 1972, the director of MAG decided to allow area farmers and ranchers to cut hay in the park's savanna grasslands. The area had been protected from fires and hunters for two years by the fledgling park staff and Peace Corps volunteers who were enraged at the ministry's decision.

Harvesting in the park was more than Santa Rosa administrator Ugalde could take and this time he decided to oppose very 
actively the agriculture minister's decision. The result was

that the minister was going to fire Ugalde from Santa Rosa. But Boza did not give him the chance; he transferred ugalde to Poás Volcano and moved the director of that national park, Vernon Cruz, to Santa Rosa. The switch seemed to mollify the ministry because Cruz was not as vociferous against the government as Ugalde. The hay cutting experiment did not turn out to be very 36 successful and the ministry never tried it again.

Larger problems loomed, however, in funding the national parks once they were created. Boza recalled,

[t] he biggest challenge we faced was breaking out of the vicious cycle between the need to develop a system of national parks and the lack of resources for doing so. We had no track record and nothing to show, so unless we could create an obvious need, we would never obtain working funds. (37)

The Forestry Law outlined how the DGF and its parks department would be funded from both regular and special budget allocations from the Legislative Assembly. Boza remembered, however, that

[i]t was always a terrible fight to have our funding needs included in the general budget, because we had to compete with programs for building highways, schools, airports, and other public works, and even with other departments in the same ministry. Those were very hard times; our arguments were weak because we lacked experience, and we did not have public opinion on our side. We survived more by luck and determination than anything else. (38)

Much of Boza's determination and hard work was directed at looking for funds outside of government sources. He started to make appeals to international assistance agencies and to conservation foundations. The world wildlife Fund was the first organi- 
zation to respond in December of 1971 with a check for five thou39

sand dollars to help with the protection of Tortuguero. Boza

undertook a far more ambitious fundraising project the same year.

He wrote a "project proposal" entitled "Pilot study of Potential

Park Sites and Reserve Areas throughout Costa Rica" and sent it

to his friend and mentor Gerardo Budowski at the IUCN in Switzer-

land. Boza wrote in the introduction of the grant proposal that

the nation was

entering a period of economic and environmental transition. . . Costa Rica's brand new parks program is trying hard to keep ahead of the tourism-outdoor recreation boom in order to preserve and protect the country's natural resource endowment while at the same time providing guidance in sound resource development. The park program's success is important internationally because of Costa Rica's spectacular, and as yet largely unspoiled ecological diversity. - A primary responsibility of the Costa Rican National Parks Department is to preserve diverse examples of Costa Rica's natural areas and to demonstrate their importance to as many people as possible. (40)

Boza went on to describe the four units that had been established that year and described other areas that were under consideration for protective status by his department. He noted that a Tropical Science Center (TSC) team of experts "with intimate familiarity with natural areas throughout Costa Rica . . and recognition in the field of natural resource conservation" had offered to conduct the "badly-needed pilot study of potential park site(s)" if funding could be obtained. Personnel on the team included such conservation minded stalwarts as Alexander Skutch to perform the ornithological research, Leslie Holdridge to document tree 
speciation and ecological community structures, Joseph Tosi to consult on other ecological interpretations, Robert Wilson (a botanist with a specialty in the study of bromeliads) to inventory flowering plants, and Olof Wessberg (from Cabo Blanco) to research the mammals of the areas under study. Steve Harrel, a specialist in forest recreation planning, would lead the team and prepare the final program for the IUCN's consideration. Boza estimated that the study would take six months and cost $\$ 25,300--$ 41 the amount he was requesting from the IUCN.

To illustrate his funding concerns, Boza wrote Myron Sutton at the USNPS regarding how it took approximately $\$ 200,000$ to get Santa Rosa refurbished and set up as a national park. He solicited help from his American friend to make some contacts for him at the offices of international conservation organizations and to help him plan a fundraising visit to the United States. Sutton obliged and helped Boza to arrange interviews at the Conservation Foundation, the National Geographic Society, the Nature Conservancy, and the Ford Foundation. Boza travelled to the United States in the summer of 1971 and was successful in marketing his country's conservation needs to the different organizations. The trip was the start of a long and warm relationship between the administration of the costa Rican park system and the international philanthropic community.

One of the areas for which funding was so desparately needed and what became one of Boza's greatest challenges was in staffing the new national parks. As one National Parks Department report 
put it, "getting professional personnel--guides, guards, laborers, cooks, and others--[was] one of the major problems of the park service" and was a "principal preoccupation of [its] direc43

tor" in those early years. Starting with the original five guards (who were paid seventy five dollars a month) and a small office staff, Boza learned to be creative in accomplishing goals and paying for projects. He used funds donated by international organizations to pay overtime wages to staff members from other government agencies, especially from the Ministry of Public works, to construct roads and firebreaks in conservation areas. He procured labor and guard duty from different local branches of the Rural and Civil Guards (Costa Rica's national police force). He utilized volunteers from the National Youth Movement (estimated by one report to be worth $\$ 8,000$ in free labor), the Costa Rican Boy Scouts, and a variety of different local youth groups to help construct paths and maintain other park services.

In 1971 Boza wanted to send two other promising conservationists to study in the parks program in the United States. He contacted Myron Sutton, the Assistant Chief of the Division of International Affairs in the USNPS (with whom he had become acquainted at the park courses), to see about the possibility of arranging courses and park visits for Sergio Salas and Ernesto Crawford. But this time Boza wanted the Costa Ricans to observe how park programs functioned in tropical settings. He sent Salas and Crawford to the Caribbean National Forest in Puerto Rico, to a national park in the U.S. Virgin Islands, and to the Everglades 
National Park in Florida. They also attended the ten-week "Introduction to Park Operations" course that the USNPS held at its facility in Harper's Ferry, West Virginia. Crawford returned home but Salas extended his trip to include visits to national parks in the American West and, upon Sutton's suggestion, even to the volcano national park in Hawail. He retuned to Costa Rica via stops in Mexico and Tikal, Guatemala, to further enrich his under45 standing of tropical conservation.

Boza also relied on other people to help with various national parks projects. He received the able assistance of scientists at the organization of Tropical studies (OTS), the Tropical Science Center (TSC), and CATIE to help with the research and planning of different national parks. Another individual, Tex Hawkins, who had helped Alvaro Ugalde during the Santa Rosa crises, offered his journalism skills to Boza to help develop a public relations program for the new parks department. Boza obviously had few funds with which to pay Hawkins so he solicited help from the IUCN. He noted that Hawkins had agreed to work for park guard wages if he could be supplemented by a $\$ 250.00$ grant--the amount Boza was requesting from the IUCN. Boza wrote that "a comprehensive natural areas public program. . . could help our new national parks office provide Costa Rica with a badly-needed environmental information/education function."

Hawkins, originally a Peace Corps volunteer, paved the way for many other workers from that organization to help with conservation efforts in Costa Rica. In 1971 the Peace corps decided to 
send twenty volunteers to Costa Rica, but increased the number when many of its workers were expelled from Bolivia due to a political crisis there. One hundred of those volunteers (not all in the field of conservation or ecological sciences) were diverted to Costa Rica--a move supported by President Jose Figueres and 47 U.S. Ambassador to Costa Rica Walter Ploeser. For Boza and the parks department, the assistance came at an incredibly opportune time--when funding and experience were scarce and needs were great. According to an agency report, the Peace Corps "was one of the most important sources for bringing in workers who could complete a diverse range of tasks--technical as well as administrative." So great was their assistance, Boza later wrote, that "at one point we had eighteen Peace Corps volunteers and only 48 twelve national staff."

Peace Corps workers were put to work in a variety of different positions. Alan Moore, for example, helped in park administration and was instrumental in developing plans for the conservation and management of volcanic areas. He solicited ideas from the director of Hawaii Volcanoes National Park in the United States who was only too glad to send letters and photographs of ideas that worked well for signs and other visitor services. Steve Cornelius was a herpetologist who not only assisted in the study of marine turtles but was also used by Boza to help draft legislation for the protection of the giant reptiles. And Christopher Vaughn was a wildlife biologist among whose early duties in Costa Rica was to research the trade in endangered species. 
In a letter regarding his project, he summed up the significance of what he and his fellow enthusiastic volunteers were doing:

Costa Rica is entering a new epoch of awareness of the value of preserving it[s] natural resources (a last stand if you want to be precise). . . . Recently the staff [at the National Parks Department] was inundated by a group of sixteen young, aware, and eager wildlife biologists, architects, and foresters from the United States Peace Corps who will spend at least two years working in many areas for specific wildlife studies. . . (49)

Vaughn, like Hawkins, stayed a long time after his two-year stint in the Peace Corps. He ended up making Costa Rica his home, wrote the management plan for Corcovado National Park, and 50

today is a professor at the National University.

Vaughn's project on the marketing of Costa Rican threatened species is indicative of the emphasis Boza placed on creating parks for their importance in protecting biological diversity-even at the relatively early date of 1971 . In a grant request to the IUCN for his project, Vaughn explained that he would be investigating the "volume and diversity of wildlife which leaves this country anually bound for international markets." He related how quetzals, "innumerable" parrots, sloths, ocelots, tanagers ("shipped sixty in a box"), and green turtles (for their meat and shells) all commanded high dollars on the black market. To illustrate the size of the problem, Boza wrote the U.S. Fish and Wildlife Service explaining how an American company was killing one hundred of the giant marine turtles a day and shipping the meat to U.S. markets. (Boza inquired as to what U.S. laws would pertain and could be enforced to halt the slaughter.) Part 
of Vaughn's mission was to use wildlife photography exhibits and other media to produce "educational programs aimed to 'turn on' the general public to the treasures they possess and stress the necessity of preserving it."

Boza took full advantage of this type of public relations opportunity that the Peace Corps workers provided. He used them to write newspaper press releases to keep the media up to date with conservation news and park developments. Jaime Socash was a a Corps volunteer in graphic arts who was put to work to design pamphlets, exhibits, signs, and color schemes for the National Parks Department. And Kirk Koepsel was a volunteer in Costa Rica in the early 1980 's who along with trail construction, maintenance, and staff-training duties, also had essential public relations responsibilities. He lobbied for support and organized trips into protected areas for residents who lived near them as a way to acquaint the people with the benefits of conservation. Many Peace Corps units have worked on conservation issues in Costa Rica since those first years of the national parks development. By the early $1980^{\prime}$ 's the park service came to rely on these volunteers but became more selective in choosing who would be accepted. In 1983 the service issued a list of "academic requisites" expected from Peace corps volunteers in four different fields: alternative energy sources, regulation of fishing, fire control/management, and reproduction of wild animals. The park service now expected workers to have degrees in mechanical engineering, hydrology, natural resource management, marine or 
aquatic biology, forestry, range management, zoology, and wildlife conservation among other degrees in those respective fields. Course work on "recovery of damaged ecosystems" or "forest regeneration" as well as field experience were highly recommended. As needs continued and the department became more professional, these criteria reflected the trend to develop more sophisticated 53 conservation policy.

Fundraising and staffing were among Boza's larger problems in the early years of the National Parks Department, but he also had to tackle other administrative and conservation concerns. Night poaching in protected areas was an on-going problem that Boza had to address and that he had to keep his few park guards ever aware of. Acquiring equipment, supplies, machinery, and construction materials for the parks became a difficult and expensive chore. Again Boza had to rely on international contributions for many of the day-to-day equipment needs of the parks. He had to find funding and materials to restore the Casona and other buildings in Santa Rosa. And he had to work on keeping a proposed jet-port out of Santa Rosa. He again solicited help from Gerardo Budowski on this matter and asked him to send President Figueres a letter explaining why an airport in Santa Rosa would be harmful to the park. Budowski sent the letter; the 54 jet-port was not constructed.

Setbacks and challenges, however, were matched by conservation successes. Costa Rica's first two national parks, Poás Volcano and Santa Rosa, were functioning well and gaining in 
popularity in the early $1970^{\prime} \mathrm{s}$. Seventy thousand people visited Poás Volcano and 15,000 visitors went to Santa Rosa between 1971 and 1972. The first foreign tourists to Santa Rosa, Californians travelling south down the Pan American highway in two pickup trucks in January 1971, found the park by accident and were pleasantly surprised with all the monkeys and other wildlife they were 55 able to observe.

Establishing the parks for the combination of conserving environmental qualities and preserving historical value was a route that helped the parks department achieve support from the public. Boza actively sought such support by preparing materials for magazines and newspapers and he wrote his own brochures that appealed to the patriotism of the readers. His pamphlet on Santa Rosa, for example, was entitled "Santa Rosa: Cuna de nuestra soberania" (Cradle of our Sovereignty). He made sure one was sent to every member of the Legislative Assembly. He also personally invited every Assembly member to the opening ceremony of the new visitor's center at Poás Volcano National Park in August 1972. Many attended. Boza also persuaded high schools to include national park information in their science curriculum, and sponsored student trips to the parks. The National Youth Movement also hosted weekend trips and work camps to the parks. Community development associations, local Rotary and Lions Clubs, and even the Folklore Dancing Club all became active supporters of the national parks cause. The strategy was applauded by Luis Fournier who wrote that "it resulted in an adequate decision with a 
double function: to protect the cultural and natural heritage of the nation as well as to provide public recreational services." These early successes did not go unnoticed by the international conservationist community. The IUCN invited Boza to speak at its Second World Conference on National Parks to be held in 1972 in Jackson, wyoming. The conference was to be held near Yellowstone--the world's first national park--and was to be part of the one hundredth anniversary of that park's creation. Boza responded that "it was a great honor to be invited to write a paper" for the conference and that he would accept "with great enthusiasm" the chance to attend the event. He wondered, however, if such a new program as that of Costa Rica's--only two years old at the time--could be of much service or example to international conservationist delegates. Frank Nicholls, the deputy director general of the IUCN, replied that Costa Rica's new parks program and recent successes made for an even better reason to have Boza speak and would serve as a stimulus for other 57 small, developing nations.

In his presentation, "Costa Rica: A Case Study of Strategy in the setting up of National Parks in a Developing Country," Boza told fellow delegates at the conference about his plans for establishing and managing Poás Volcano and Santa Rosa. "The common feature of these two parks," he began, "is that they are attractive both to the people of the country and to visitors from abroad, are of easy access, and have great national significance, conditions which made their establishment possible without oppo- 


\section{8}

sition from anyone." while this optimism obviously downplayed the opposition of local stockgrowers in and around Santa Rosa; it did represent a majority of sentiment for park creation in those years. One newspaper reporter related how Boza, "in his quiet, studious manner," told of how Costa Rica's park development did not have "the explorer's drama that surrounded the start of America's national parks at yellowstone a century ago," but how it was "an idea whose seed must be carefully planted and nurtured to obtain public support that will allow it to compete with the nation's other demands." Boza also spelled out in his presentation how the strategy of Costa Rica's park service was to start small and protect well what was designated rather than to have too many parks to manage all at once. Success in early park development would hopefully set off a chain reaction of public support to conserve other areas in the country.

It worked. Other national parks and reserves were created in the early 1970's: Manuel Antonio National Park on the Pacific Coast (1972); Rincón de la Vieja National Park--an active volcano in Guanacaste that is home to hot springs, fumaroles, hidden waterfalls, and mixed dry and evergreen forests (1973); Guayabo and Negritos Biological Reserve--rocky islands in the Gulf of Nicoya that are a haven for shore bird rookeries and tropical dry forests (1973); Guayabo National Monument (coincidentally with the same name as the island reserve but actually inland near Turrialba)--Costa Rica's largest archaeological zone with 
pre-Columbian Indian ruins dating back to 800 A.D. (1973); and Barra Honda National Park--a series of steep caverns on the Nicoya Peninusla that were not "discovered" until 1967 (1974).

Each of these new parks has its own story on how it was selected, planned, and eventually designated and managed by the National Parks Department. Newspaper articles gave attention to each area and advocated their protection. Manuel Antonio National Park (named after a Spanish conquistador who is buried there), however, was an area not originally sought after by Boza and the parks department. That park was the product of 10cal initiative--a drive by residents there who, so unlike locals near other areas such as Cahuita and Santa Rosa, actively campaigned to conserve the area as a national park.

Manuel Antonio had at one time been owned by the United Fruit Company (the result of a land trade by the government of Costa Rica). Due to its terrain, however, the firm never cleared it for banana production and thus later sold it to other private interests. Boza, who had never been to the Manuel Antonio beaches and forests on the Pacific Coast and who was busy dealing with crises in other parks, was reluctant to take on another project in late 1971 and early 1972. Vernon Cruz, the one time director of Poás Volcano and Santa Rosa national parks, however urged that he look into the possibility. Cruz had spent personal time at Manuel Antonio and was familiar with why residents of Quepos (a town near the park area) and others were fighting to save the land: not just for the beauty of the mixed tropical 
forest that meets the Pacific with pristine white-sand beaches, but also because they were opposed to the foreign capitalist developers who were trying to build luxury resorts there. Quepos had a history of avid syndicalist activity since the 1930's and had elected Communist Party members to the Legislative Assembly. The people there were just not ready to have outside capitalists come in with disregard to local feelings. A variety of groups, including a small farmers' association, the high school student council, a chapter of the local National Youth Movement, and a prominent leftist family all became involved in working to keep the developers out. Some people even resorted to "monkeywrenching" tactics like cutting down fences and threatening to bomb the gate of a construction site. Thus, Cruz convinced Boza of the bright opportunity that existed for park expansion, and the two of them, along with Peace Corps volunteer Christopher Vaughn, flew down to the area and surveyed it as a potential park site. Boza must have been impressed with what he saw. When he returned to San José he drafted a bill to declare Manuel Antonio a national park and got a Quepos diputado to sponsor it in the Legislative Assembly. A delegation from the Assembly toured the area, saw the destruction started by the construction firm, and rallied for the bill's approval. President Figueres signed it into law and a bond was levied to buy back what had originally been government property and to pay for its development as a protected area. Today, Manuel Antonio is the smallest but one of the most visited of Costa Rica's national parks--averaging about 
200,000 visitors a year.

Manuel Antonio and the other new parks were designated during the 1970-1974 administration of President José Figueres. While it was Figueres' pen that signed the parks into law, their creation and successful operation did not come without the determination, hard work, and support of various individuals inside and outside of the government. Mario Boza spearheaded the work, but he had the welcome support of many fellow biologists, geographers, and social scientists at Costa Rican universities. According to Alexander Bonilla, one such avid supporter, professional associations as well as mountain climbing and caving clubs, environmental groups, garden societies, and youth groups all "played very important roles in the development of these wild areas." International organizations like the IUCN, world Wildlife Fund, Nature Conservancy, Sierra Club, and various European environmental groups all continued their financial and technical assistance. Moral support also came in from overseas sources. French conservationist Jean-Paul Harray wrote Boza to congratulate him on his efforts for park creation and conservation and especially for the opening of Santa Rosa National Park. Prince Bernard of the Netherlands and Prince Philip of England were two specifically influential people involved with international conservation concerns who Boza remembers as being "very pleased to lend themselves to 64 our cause."

One organization that was extremely helpful in technical 
assistance and moral support was the U.S. National Park Service. Boza had struck up a friendship with Julio Marrero of the USNPS in Puerto Rico and often corresponded with him on matters of tropical conservation. Myron Sutton, the Assistant Chief of the USNPS Division of International Affairs who had spoken at the ceremony inaugurating Santa Rosa National Park, continued to keep in touch with Boza and to offer ideas and support. Sutton sent Douglas Cuillard, a naturalist at Everglades National Park, down down to Costa Rica several times to consult on various projects. One that Cuillard assisted in was helping to develop a network of paths that would survive the high rainfall and moist conditions at Poas Volcano. Cuillard sought the advice of the director of Olympic National Park in Washington state who was used to similar weather patterns and found out from him that a gravel and wood-chip combination withstood the Pacific Northwest's rainy conditions better than other path-building materials. Othello wallis from the USNPS regional office in San Francisco provided advice on developing marine national parks and Arthur Hewitt, the acting superintendent of Hawaii Volcanoes National Park, was consulted on protecting volcanic areas. Boza and his small staff also received assistance and moral support from international agencies. Gerardo Budowski from the IUCN and Kenton Miller, then at the FAO's forestry division in Rome, often offered encouragement and assistance. John Moseley, a park planner with the FAO, provided help with a long-range planning process for the National Parks Department in 1972 . John 
Milton, the director of international programs for the Conservation Foundation in Washington, D.C., took special interest in the Costa Rican early parks experience and got his organization to help fund projects. The Costa Rican government applied for and received a $\$ 1.8$ million loan from the Central American Development Bank for the development of Poas Volcano National Park. And the Peace Corps, the British Volunteer Services Organisation, and the Caribbean Conservation Corporation continued to send muchneeded volunteer workers throughout the seventies and eighties. The early years of the development of national parks in Costa Rica bear the very heavy imprint of Mario Boza and Alvaro Ugalde. Indeed, Boza has written that he and Ugalde and others 67 "launched the conservation movement in Costa Rica." While this is not too much of an overstatement, David Rains Wallace, in his authoritative study of the Costa Rican national parks, places the role of the two men in its proper perspective:

Many writers have called Boza and Ugalde the founders of the costa Rican park system. In a sense, this is an exaggeration: It was the Costa Rican leadership that founded the parks, the politicians and civil servants who drafted and passed the park decrees, and the scientists and conservationists who helped and pushed them to do so. Yet in another sense, it is quite true, because both men have shown an extraordinary dedication to the system. They not only helped start it, but kept working for it throughout their careers, sometimes at considerable personal cost. (68)

One of the people who helped them in those early years was Vernon Cruz. After his stints as director of Poas Volcano and Santa Rosa, Boza created an administrative job for him back at park headquarters in San José. He became a "floating administrator" 
to visit potential park sites, to present slide programs regarding the park system, and to visit with communities that might be affected by park development. He remembers very well how hard he, Boza, and Ugalde worked in those early years and why they kept it up:

We really never stopped working, although we were supposed to get a week off every twenty-two days. Sometimes we'd work through the night at Boza's house. He was always working all the time with lots of projects. He kept us busy with all his ideas. It wasn't really working. We liked the problems, the feeling of responsibility for the nation's resources. The support of the workers was the strong base of the parks from the beginning. The conditions were poor and hard, but all anybody thought about was how fantastic nature was, and how important it was to protect it for everybody.

Interestingly, for as much as Boza and Ugalde worked together, they have been described as having quite opposite personalities. The "reticent, scholarly" Boza and the "outgoing, combative" Ugalde seemed to balance each other out. Likewise, they were members of rival political parties; Boza to the more conservative Christian Unity Party (dominated by the Calderon family), and Ugalde to the more liberal National Liberation Party (of the Figueres legacy). One study in the 1970's reported that "some people surmise that the two friends maintain affiliations with opposing parties so that no matter which side wins an election, the parks will have an advocate with connections."

Connections or not, Boza learned that he was going to be transferred out of his position in 1974. José Figueres' presidential term had expired and the winner of that year's election was none other than Guanacaste rancher/lawyer and president of the 
Legislative Assembly, Daniel Oduber Quirós. Although Boza was not of Figueres' political party (the PLN), he nonetheless had retained his position as head of the National Parks Department. Oduber was also of the PLN but replaced Figueres' minister of MAG with Rodolfo Quirós who was over the parks department and evidentIy wanted political unity within his ministry. Boza left to help develop a school of environmental sciences at Universidad Estatal a Distancia (National Open University) but cleverly maneuvered to get Ugalde (who was PLN) appointed his successor at the parks de71 partment.

Thus a new chapter of Costa Rica's conservation history opens with Alvaro Ugalde as director of national parks. Mario Boza remained active in conservation efforts throughout the next decade, albeit in different venues of the private and public sectors. Most importantly, a system was now in place to conserve the nation's natural heritage, it was functioning with responsible personnel, and conservation in general was gaining in popularity with Costa Ricans. The system was soon to be tested by the challenges that lay ahead. 


\section{CHAPTER 5}

CONSERVATION CONTINUED: THE ODUBER ADMINISTRATION

I believe nature's beauty is for everyone to enjoy, not just a few. . . . [T]his small country, just 100 miles wide by 400 miles long, has a diversity of climates and species that makes it important from the scientific point of view. That's why we want to keep as much of our territory as possible in a condition to be studied and enjoyed by people.

- Daniel Oduber Quirós (1)

\section{"The Greatest Friend the National Parks Ever Had"}

\section{After Alvaro Ugalde's transfer from Santa Rosa to Poás Vol-} cano and after he had worked as director of that park for about a year, he decided it was time to consider getting a Master's of Science degree. He took a one year leave from the parks department in 1973 to study at the University of Michigan's School of Natural Resources on an OAS (Organization of American States)

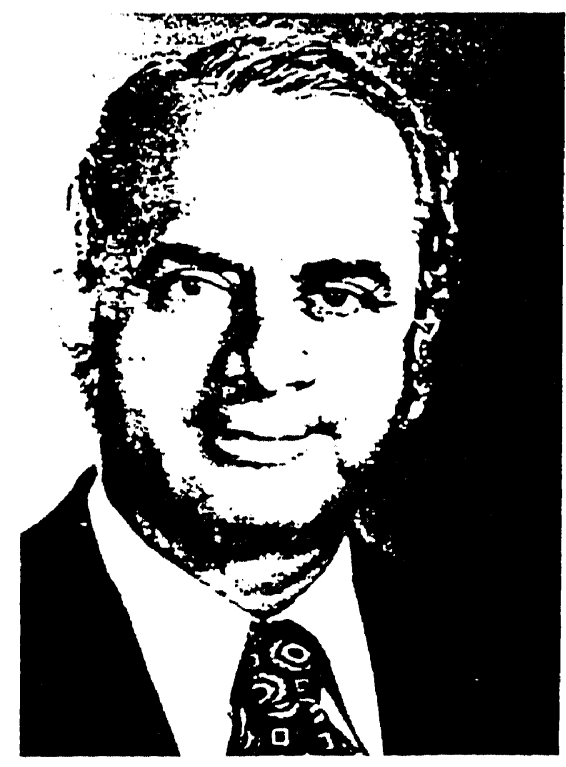

Figure 1: President Daniel Oduber Quirós

(source: Harold H. Bonilla, Los presidentes [San José:

Editorial Texto, Ltda., 1985)] 
scholarship. Upon his return to San Jose in 1974 he learned that he had been appointed director of the National Parks Department in the new administration of President Daniel Oduber.

That Ugalde and Oduber were of the same political affiliation, and that Mario Boza had assisted in the nomination process, were assuredly factors in Ugalde's appointment. But the move was surprising in some ways since Ugalde had locked horns with Oduber on the Santa Rosa controversy of 1970. Several years later ugalde mentioned in an interview for a report on the park system that he tried to stay out of Oduber's sight the first few months he was in office:

But one day I ran plunk into the President coming out a building. 'Ah, Ugalde! Where are you now?' the President asked. 'In the parks department,' I replied. 'Come see me,' he said. My heart sank. But I was surprised. Instead of Oduber being revengeful, he became the greatest friend the national parks ever had. (3)

President Oduber's interest in national parks stemmed largely from his belief that the parks could be an economic boon for tourism. This was actually an insightful stance since the term "ecotourism" was hardly in use in the mid-1970's and Central America was hardly a popular destination for foreign tourists. But Oduber saw the value of national parks for use by local Costa Ricans as well. Early in his term he proposed spending $\$ 3.5$ million to create a series of small urban parks within a half hour's drive of San Jose in second growth forest and farm lands of the Central Valley. This "great recreational reserve" idea never materialized but oduber was successful in dramatical- 
Iy increasing the size of the Costa Rican park system that did open the door to thousands of Tico and foreign tourists. In their book on Costa Rican national parks, Mario Boza and Rolando Mendoza wrote that Oduber and Rodolfo Quirós, the new director of the agricultural ministry (MAG), gave priority to programs dedicated "to the conservation of nature and renewable resources as a way of contributing to the country's socio-economic development."

For tourism or conservation, then, expansion of the national park system continued at a rapid pace during oduber's term in office (1974-78). More importantly, conservation successes occurred without the controversies that had marked the earlier years of park development. "Fights during the oduber administration were almost non-existent," Alvaro Ugalde later recalled, "[t]he president was supporting everything." Naturalist Allen Young, who conducted research in Costa Rican national parks during this time period, wrote that oduber "nurtured and developed" 6 the park system.

The praise is well deserved. By presidential decree Oduber created the large national parks of Tortuguero (previously protected as a nature reserve only), corcovado (a remote tropical wet forest on the Osa Peninsula in Southeastern Costa Rica--one of the most species-rich areas in the entire country), Chirripo (Costa Rica's highest mountain at 12,500 feet and home to one of the only Andean páramo life zones in all of Central America), and Braulio Carillo (a tropical wilderness area of steep, forested 
mountains just north of San José). He also approved measures to amplify Santa Rosa National Park, to provide more developed services at Rincón de la Vieja National Park, to establish the Dr. Rafael Lucas Rodrfguez and Palo Verde national wildlife refuges and the Isla del Cano, Hitoy-Cerere, and Carara biologi7

cal reserves. (See map, page seventy-fike.)

All totaled, national park and equivalent reserve acreage nearly doubled during the oduber presidency. The country's percentage of territory designated as protected jumped from 2.5 per8 cent in 1974 to 4.5 percent in 1978. Likewise, the creation of each of the new parks or reserves reflected a growing conservation ethic in Costa Rica in the mid- to late $1970^{\prime} \mathrm{s}$. And like the earlier parks, each of the protected areas had its own particular genesis story. The origins of Chirripó, Corcovado, and Braulio Carrillo especially exemplify the links between a nascent but growing environmental movement and the development of national parks and protected areas.

Chirripó (sometimes referred to as Macizo del Chirripó or Cerro del Chirripo) in the Talamanca range in south central Costa Rica was promoted by the mountain climbing club of the University of Costa Rica. Club members had started lobbying for the mountain's protection and designation as a national park in 1972 and their efforts finally paid off when President Oduber declared it such in August 1975. But leaders in the club valued the peak for more than just climbing and hiking; they understood how conservation would help to preserve the mountain's variety of eco- 
systems. The park is approximately 109,000 acres that includes not only Chirippo's peak, páramo grasses and shrublands, and glaciated valleys, but also thousands of acres of rare high altitude oak forests that originally were to have been protected (but never really were) in the $1940^{\prime} \mathrm{s}$ as a "national park" along the Pan American Highway. These forests are a vital part of a network of watersheds that provides hydrological power to generate electricity to tens of thousands of costa Ricans. The benefit of conserving Chirripó and its environs for its ability to produce electrical power, then, helped the mountain climbers sell the idea of converting the area into a national park.

Chirripó National Park is testimony to the work and success of Costa Rica's budding conservation movement. UCR mountain climbing club members Adalaida Chaverri, Alfonso Mata, Jorge Moya, and others who led the lobbying effort for Chirripó, became active participants in the Costa Rican environmentalist community. Adelaida Cheverri later served as one of the Costa Rican delegates to the Central American Meeting on Management of Natural and Cultural Resources in 1974 and went on to write her Master's thesis on the importance of private biological reserves. Alfonso Mata was also involved in the Central American conference and became an ecologist at the University of Costa Rica and the Tropical Science Center and has been an authority on environmental pollution and water quality. He has conducted exhaustive research and written many articles on the ecological impact of contaminants in water systems, especially pollution from chemical 
insecticide run off, and was a key figure in the First National Symposium on Environmental Pollution held in San José in 1980.

The history of Corcovado National Park--100,000 acres of rare and endangered Pacific Coast rainforest--also begins with individuals in the scientific community who lobbied for its protection. The reason so many people were concerned is that the forests of the Osa Peninsula represent a unique ecosystem in Central America that was quickly being threatened. Christopher Vaughn, the Peace Corps volunteer who wrote the management plan for the park, asserts that Corcovado is the only remaining Pacific Coast tropical wet rainforest in the region and possibly in 11

all of Latin America. Tropical botanist Gary Hartshorn, who started visiting the Osa Peninsula in the mid-1960's, agrees and explains that Corcovado's forests, complete with over 500 species of trees,

are the only wet forests still extant on the Pacific side of Central America. The abundant rainfall coupled with a short, three-month dry season seems ideal for tree growth, for these forests are by far the most exuberant in Central America. In fact, the Corcovado forests are just as impressive. . . as the best forests I have seen in the Amazon Basin or. . [in] Malaysia and Indonesia. (12)

Such a place also represents the home to the largest populations of Baird's tapirs and jaguars in all of Central America and is habitat for hundreds of bird, reptile, and amphibian species. The problem was that such an impressive forest was drawing the attention of logging companies and the rivers and hills of the Osa Peninsula were attracting mineral prospectors. Unbe- 
knownst to colonial conquistadors or explorers, the peninsula was laden with gold. Prospectors did not start mining there, however, until the $1930^{\prime} \mathrm{s}$ and more and more people trickled into the area by the 1960 's. Timber companies cut trees, speculators sold land, and squatters followed to set up farms on cleared land or commenced panning for gold. To obtain legal title, the precaristas (squatters) needed only to occupy the land for three years. Many aggressively defended their territory with guns, creating a truly violent mid-twentieth century "frontier" atmosphere on the Osa Peninsula.

By 1972 the situation was dire enough to draw the attention of biologists and conservationists. Some environmental studies had previously been conducted on the peninsula, but none had recommended creating a national park. Forest ecologists Leslie Holdridge and Joseph Tosi from the Tropical Science Center (TSC), for example, had been hired by a large timber firm in the mid-1950's to develop forest management plans for the area. While they did not specifically recommend protected status for the Corcovado region at the time (there was no forestry law or national park service in existence yet), they did see the area's value for tropical research. They opened a TSC biological field station on land leased from the timber company in 1964 and shared the facility with students from the organization for Tropical studies (OTS). others continued investigating the Osa's tropical forests. on the recommendation of Christopher Vaughn, who visited the area with a group of hikers in 1972, Mario Boza and Alvaro Ugal- 
de from the parks department flew over the peninsula to consider it for park status. Ugalde supported the idea, but Boza was not in favor due to the population of precaristas living in the region. But as time moved along, economic interest in Corcovado's trees and land increased. A Japanese firm was looking into logging the area and a U.S. firm was interested in converting the subsequently cleared land into citrus groves. Many letters from conservationists around the country in support of Corcovado becoming a nationally protected area started pouring in to the national parks office. When Ugalde assumed the directorship of the parks department in the oduber administration, then, he rekindled the idea of a national park in the Osa Peninsula. He sent Olof Wessberg (the Swedish orchard farmer who had worked so hard to establish the Cabo Blanco Absolute Nature Reserve) on an 14 initial park feasibility study.

Wessberg and his wife Karen Mogensen had been intrigued with the Osa Peninsula by the reports they had heard of its tapir poplation and exotic plant species. Mogensen first visited Corcovado in June of 1975 and related how beautiful and pristine it was. Her husband went later the next month, as Mogensen recalled in an interview with David Rains Wallace, overtly to look for a differrent species of avocado tree to add to his orchard at home in the Nicoya Peninsula. In an interview with Bill weinberg, however, she admitted that wessberg was actually on a mission from the parks department to survey the area. Either way, wessberg never returned. He was killed by a machete blow to the head by a local 
man who had accompanied him into the rainforest. The murder was shrouded in mystery; the man admitted to the killing, then recanted and blamed his father, then later admitted it was he who was the murderer. Was it a conspiracy? Mogensen, crushed by the news, raced to Corcovado to search for the body and found it. She later told weinberg that the police investigation was inadequate and that she believed the murderer was paid to commit the crime. She continues to live in a modest home in Montezuma near Cabo Blanco where she can commune with the monkeys and coatimundis who she believes "are so much happier than we are... [and] are much more intelligent." "They can live on the land for thousands of years and leave it beautiful," she philosophized, "[w]e humans come in and in twenty years it is destroyed."

Less than a month after Wessberg's assassination, President Oduber announced his decision to support the creation of a Corcovado National Park. "The foreigner who died to defend natural resources deserves a monument," Oduber told a La República newspaper reporter. He compared the crime to the violence in the Middle East but suggested that "here we kill people for defending a tree, an animal, a plant. . . [t]his is very serious." Two months later, to the dismay and disgust of some of his cabinet members, President Oduber declared Corcovado a national park. Most of the land was government property and the rest was acquired from a timber company through a land swap. Oduber promised full support and funding for the park's development and operation and offered a start-up grant of over $\$ 100,000$ from his 
presidential discretionary fund. The parks department also received $\$ 10,000$ from both the World Wildlife Fund and the Rare Animal Relief Effort to be used for Corcovado. Nine guard positions were created and eleven members of the Rural Guard were 17 posted in the newly designated park.

The problem was that Alvaro Ugalde had estimated that only forty-five families would need to be removed from the park and that the total cost involved, including he park start-up expenses, would be around $\$ 175,000$. He soon learned, however, that there were more than fifteen hundred precaristas with hundreds of head of livestock. Some families had been living in the area for over twenty-five years and all squatters, by Costa Rican law, had to be reimbursed for "improvements" to the land. And because there were no roads into the park, all families and livestock would have to be moved by boat or airplane--further increasing 18 the cost of the relocation effort.

Ugalde had to approach President oduber with the new information and that the cost would be more like $\$ 1.2$ million (ten million costa Rican colones). "I was sure I'd be fired the day I had to tell the news to the President," Ugalde said in an interview to two U.S. reporters, "[b]ut he took it calmly, telling me: 'It may cost ten million colones now, but how much more would it cost fifty years from now? We will do it." Ugalde was delighted. "Corcovado has been a real exciting experience," he wrote a friend at the U.S. National Park Service a few months after the park was declared, "[w] ith the president backing us, we have been 
able to get from the government two million dollars in six months and the old dream is now a reality. . . I am as optimistic as ever."

Braulio Carrillo National Park in the Cordillera Central north of San José was also the result of a spirited lobbying campaign by members of Costa Rica's scientific and conservationist community. Understanding the history of its creation, however, requires a brief review of the background involved. The park was named after the country's third president from the 1830's who worked to create national unity and dreamt of uniting the caribbean and Pacific ports by roads with the population centers in the Central Valley. His efforts eventually resulted in a road from San José to Puntarenas on the Pacific Coast, but the steep, densely forested mountains of the Cordillera Central that separate San Jose from the Caribbean lowlands prevented much of a road from ever being built there. Transportation for nearly one hundred years was limited to a railroad that had been constructed in 1882 by a division of the United Fruit Company or an extremely slow, curvy road going south from san José to the port town of Limón via Cartago and Turrialba.*

\footnotetext{
* Braulio Carrillo first became president when his predecessor, José Gallegos, resigned in 1835. He returned to power in 1838, declared himself dictator for life, and announced that Costa Rica would separate from the United Provinces of Central America. Four years later he was forced to flee the country and was assassinated in El Salvador. While Costa Ricans normally deplore dictators, the national park was named in his honor because of his efforts to end national isolation by building roads from coast to coast.
} 
For over a century, then, the need had been great to construct an improved road from the capital to the caribbean. It was not until 1973, however, that serious plans and financing materialized for the project. As a part of an effort to bring modernized transportation and communications to Costa Rica to assist in its economic development in the early to mid-1970's, the World Bank agreed to finance a modern highway that would run north out of San José and then over the tropical mountain range to connect with the town of Guápiles in the Caribbean lowlands. But when the Bank hired the Tropical Science Center to conduct an environmental impact study on the project's feasibility in 1975, it learned that a modern road through the mountains could open the area to agricultural colonization, cause massive deforestation, and severely threaten the variety of ecosystems that are found in the region. The study was conducted by Leslie Holdridge and Joseph Tosi who also found that massive deforestation in the Cordillera Central would result in heavy flooding with disastrous effects on the people and their economy in the Caribbean lowlands and would destroy the very highway being built. The TSC study, then, only approved the highway project with the condition that a conservation unit be declared to protect the forest surrounding 21 the proposed road.

With Alvaro Ugalde as its director in those years, the park service lobbied to declare a region far greater than just the area surrounding the highway to become what is today Braulio Carrillo National Park. Ugalde and his department received the 
welcome support of conservation groups around the country. One of the groups that was the most active on the issue and that worked to make sure conservation measures were implemented during the road's construction was the Colegio de Biologos (Biologists' Association). UCR biologist Pedro León, a member of that organization who was particularly involved on the cause, claimed that Braulio Carrillo was "a classic example" of a successful "compromise." He remembered that "there was a lot of concern and organized pressure from all sorts of groups about the road." He wrote letters to government officials on behalf of the Association saying that "unless a park was created along the road, there wasn't going to be a road--that erosion would destroy it." President Daniel oduber agreed and signed an executive decree to declare the area a national park in 1977 . The Legislative Assembly approved the measure a year later (with some modifications), and thus created an 80,000 acre park, most of which is non-accessible wilderness. Gerardo Budowski once said that "Braulio Carrillo may be one of the most interesting parks in the world, totally unknown even though a half hour away from a big city." The park had nearly 4,000 visitors its first year of operation. The San Jose-Guapiles Highway was completed in 1987--nine years after the park declaration.

To assist in such an expanded parks program oduber worked to increase the parks department budget from $\$ 600,000$ in 1976 to $\$ 1,750,000$ in 1978 . The department's staff tripled (it doubled in 1977 alone) and included four hundred employees by the end of 
oduber's term. The president assisted conservation efforts in other ways also. He declared 1977 as the "Year of Natural Resources." He issued decrees providing legal protection to many endangered species including quetzals, macaws, manatees, tapirs, jaguars, ocelots, and other felids, birds, and reptiles. He assisted in acquiring international financial assistance for conservation projects. The U.S. Agency for International Development (AID), for example, loaned the government of Costa Rica $\$ 1.2$ million for a five year management plan for Braulio Carrillo 23

National Park. Smaller amounts came in from Philadelphia Conservationists, Inc. (on whose board Theodore Roosevelt III was an influential member), The Nature Conservancy, the Natural Resources Defense Council (NRDC), and the Rockefeller Foundation. The NRDC's funds were to be used specifically for researching sustainable development and deforestation issues. The University of Michigan School of Natural Resources donated money to the National Parks Fund and the London-based World Pheasant Association was interested in protecting currasow and chachalaca habitat in cor24 covado.

Alvaro Ugalde learned that not all of the international conservation groups' funds came easily. The Nature conservancy's international office, for example, sent a representative to Costa Rica in 1977 who expected five-star service. In a letter to Ugalde after her visit, Sandee Garihan wrote that "there should have been a well-organized itinerary for me to see most of the country as possible." She went on to complain that she had to find even- 
ing entertainment and the theatre by herself in San José. And she advocated keeping an airstrip in Corcovado (a decision that Ugalde and the parks department had been struggling with) so that people like her on tight international schedules could enjoy a visit to even the remotest of areas.

In a most telling letter of response, Ugalde not only addressed Garihan's concerns, but provided a rare glimpse into his insights that were compounded by the hectic schedule he was forced to keep. He opened the letter by apologizing for the delay of his response--"due to the amount of work and lack of help" and continued:

lately I have had hardly any time of my own . . . Sometimes I feel very tired, but unless I have been brainwashed, I believe we don't have much time in this mad race against destruction. There are not many more individuals in Costa Rica working in this field, therefore I cannot just simply send everything to hell. . Although we make a lot of mistakes, I just hope that what I am doing is the right thing and not just a waste of time.

Several months later Garihan replied to Ugalde's heartfelt message, apologizing that it took her so long to write, but that after her trip to Costa Rica she had to take a one week vacation in Tampa (where she "loved the theatre") to recuperate from Costa Rica and that she had just returned from "a six week jaunt on the French-Italian Riviera."

\section{The SPN}

One of the most important changes that occurred during the Oduber years was in the status of the National Parks Department. First, in 1975 the department within the General Forestry Direc- 
torate (DGF) was elevated from its "subdirectorate" to a "general directorate" with greater individual autonomy. Then in 1977 with the Legislative Assembly's approval of the National Parks Act, it was completely separated from the DGF and became the National Park Service (Servicio de Parques Nacionales, SPN)--its own division within the Ministry of Agriculture (MAG). The change of status was more than just bureaucratic shuffling; it established the legal framework for the SPN's work and provided the freedom for the SPN to expropriate land for parks. The Act specifically made it illegal for any part of a national park to be removed from park status except by legislative decree. It allowed the SPN to set entrance fees, to make recommendations for new parks, to define park regulations, and generally to expand its services with fewer hierarchical hurdles to surpass. It was a change that Mario Boza and Alvaro Ugalde (who retained his job as head of the newly named SPN) had been advocating for over five years and one that took a great deal of hard work to pass.

Lobbying for a more autonomous parks department within MAG began in 1972 when Mario Boza sent a draft "Creación del Servicio Nacional de Parques" proposal to the Legislative Assembly. The introduction of the draft legislation outlined how a separate parks service with its own budget could better promote recreation and tourism, the conservation of nature, scientific research, public education, the preservation of historic and archaeological areas, and the protection of watersheds and indigenous reserves. The proposal was sent to committee, specifically the commission 
on Social Affairs, where it was bantered around until 1977.

Edwin Múñoz Mora, chairman of the Commission on Social Affairs, contacted Mario Boza in the summer of 1972 and requested more information on why the parks department wanted to be a separate entity. Boza responded in a letter that detailed similar reasons that were outlined in the draft proposal's introduction and explained that meeting the demands of the public as well as those of the urgency of conservation could be better met with an autonomous department. He also lobbied other members of the Assembly by sending them brochures about national parks and made sure each member was personally invited to the grand opening of Poás Volcano in August of 1972 so that they could witness first28

hand the work of the new program.

Lobbying both for and against the proposal occurred during the early 1970's when the bill was in committee. The Association of Costa Rican Industries opposed the measure, explaining in a letter to Diputado Múñoz that a separate national parks division would be "too ambitious for Costa Rica" and would be too expensive. Members of that organization saw the proposal as a new way to levy unnecessary taxes on businesses and considered Costa Rica's ratification of the International Convention for the Protection of Flora and Fauna to be sufficient for wildlife conservation. Groups in support of the measure included the Association of Biology students who wrote Munoz urging his committee to approve the bill and send it to the Assembly as a whole. "The 
richness of our wildlife," one letter from the group began, "is converting itself into a myth." It went on to suggest that a more powerful parks division would be able to conserve more effic29

iently the country's natural resources.

One of the most important proponents of the National Parks Act was none other than Karen Olsen de Figueres whose husband was still President of Costa Rica when the bill was first under consideration. In fact, as Mario Boza explained in a testimony to the Commission on Social Affairs in November of 1973, it was Mrs. Figueres who was one of the project's originators. She had supported Boza and his proposal from the beginning and worked to lobby various diputados for its approval. Boza also explained to the commission that such problems as night poaching and an insufficient number of park guards were reasons that Doña Karen and others saw the need for granting the parks service more legal authority and funds with which to protect the parks and reserves. The legal authority of the new act, according to former park service attorney Ana María Tato, was one of its most important features. "The importance of all of [the act's] jurisdictional regulations," Tato wrote, is that "present and future generations will obtain an incalcuable benefit." The act made very clear fifteen prohibitions for visitors and property owners in and around the parks that would serve as the legal base for park acquisition and land expropriations. All of the property and expropriation guidelines, she explained, advance the "national park objectives" and represent a legal "necessity" as opposed to arbi- 
trary decisions [made by different] administrations."

In late 1974 the commission studying the proposal amended it to move the SPN out of MAG and into the Ministry of Culture, Youth, and Sports. Members evidently felt like there would be less competition for management of natural resources if the parks division were transferred to an entirely different ministry. The new version of the proposal was eventually sent to the Assembly as a whole, but it did not come up for a vote for two more years. The amended bill named the parks service the Directorate of National Parks and Monuments under the Ministry of Culture and did not give it the status it would have had as a separate division of the Ministry of Agriculture. It passed the Legislative Assembly in late 1976 but was vetoed by President Oduber. The Assembly sent the bill back to committee. In May of 1977 the Commission on Social Affairs called on parks director Alvaro Ugalde to testify. In his statement, ugalde recited why he agreed with Oduber's veto (it would not have given the SPN the funds, independence, or legal authority it needed) and urged the 32 members to restore the bill to its original wording.

After little debate back in committee, the Commission acted on Ugalde's request and sent a revised bill to the Assembly. Opposition there continued to center on the fear that the new directorate would increase taxes. But it did finally win approval in August of 1977 and President Oduber signed it into law. The new SPN seemed to function better on its own accord within MAG and 
lasted there for nine years. In 1986 it was transferred to a newly-created Ministry of Natural Resources (MIRENEM) but retained its "directorate" status. In 1994 MIRENEM was changed to the Ministry of Environment and Energy (MINAE) and the SPN was dissolved. In its place is the National system of Conservation Areas (SINAC) which manages national forests, parks, monuments, and biological reserves.

Designating new parks and having the active support of the President for a more independent and better financed park service, however, did not solve all of Ugalde's problems. In 1975, for example, trouble brewed when the parks department announced plans to expand Cahuita National Monument on Costa Rica's southernmost Caribbean coast. Residents there were upset to learn that the government was planning to expropriate more land in the area to develop Cahuita into a national park. They thought that "national park" designation would convert their small town into an Acapulco-style beach resort and hotel complex and bring with it the attendant social problems caused by tourist zones. Local farmers and fishermen opposed the plan thinking it would infringe 34 on their livelihoods.

Opposition to the parks department culminated at a public hearing held in the town of Cahuita. Ugalde attended the meeting to represent his department and argue for the development of the national park, but, as he later related to reporters Robert and Patricia Cahn, "it seemed like I was the only defender." Because residents of this part of Costa Rica are mainly black, English- 
speaking caribeños, however, Ugalde switched to English during his presentation which greatly aided his cause. "[A]fter I explained to [the] Cahuitans that the real threat came from the land developers and wealthy people from San José who wanted beach-front vacation homes or land for speculation," Ugalde recalled, "the local people realized that the park would give the best protection to their way of life." When the people at the town meeting voted, the result was a near unanimous decision to 35 support the park.

News of Costa Rica's park creations and expansions started attracting foreign visitors in the mid- to late 1970's. In 1978 (President Oduber's last year in office) over 34,000 foreigners visited the national parks and reserves. While that figure represents only slightly less than ten percent of the total park visitation numbers $(n=357,000)$, it does signal the start of a trend. Many foreigners, especially those from the United States, wrote (amazingly!) directly to park service chief Alvaro ugalde to request information and maps of different protected areas. A thick file of such letters exists from 1976-77 in SPN records at the National Archives. Most of the requests (paraphrased here) began with "I have recently read (or heard) that... . Can you please send... . Many even asked what type of gear they should bring for certain areas of the country for different times of the year. Ugalde responded to every request.

Mario Boza, Alvaro Ugalde, President Oduber, and other park proponents of course were pushing tourism as an economic benefit 
of national park development, but sometimes foreigners got the wrong idea about conservation in Costa Rica. An article written by Doris Deakin for The Washingtonian in early 1977, for example, praised Costa Rica as "a great escape to go hunting." When Ugalde saw a copy of the article he was enraged. He penned a no-nonsense, strongly worded letter to the paper's editor-inchief explaining how the park service was having enough trouble as it was with poaching and trying to restore populations of endangered species without that paper blabbing that the country was a haven for hunters. He related how conservation areas in Costa Rica were intended for the free transfer of biological properties and were to be used for scientific research or to be enjoyed for their scenic and natural values.

In fact, other relations with the United States started to sour somewhat in the mid-1970's. Although Mario Boza had enjoyed a strong working relationship with the U.S. National Park Service's Division of International Affairs during his time as parks chief, Ugalde's experience with the USNPS was less productive. gain without mincing words, Ugalde wrote one staff member of that division in the spring of 1976 that "it would be important to see some more interest in Latin America from the U.S. Nationnal Park Service; up to now, relations have been rather cool." He did not specify exactly what he wanted from the USNPS in that particular letter, but three months later he reiterated his concern directly to the head of the Division of International Affairs, Robert C. Milne, saying, "I look forward to warmer rela- 
tions between us."

Ugalde was frustrated in those years because despite the designation of more national parks in Costa Rica, deforestation in unprotected areas was causing grave environmental dangers. In a report to the Legislative Assembly in early 1976 he warned that the "situation is extremely critical"--that Costa Rica was in a "state of true ecological catastrophe." He explained that "enormous clear-cuts" were damaging "important watersheds" and that extensive forest fires were occurring on a daily basis. He pointed out that although forest destruction threatened the survival of wildlife, it also created severe problems for humans by decreasing hydropower potential. To stem this tide, the government conducted studies to establish more forest reserves (apart from national parks). Two hundred twenty-five thousand acres were set aside as reserves, but, as Luis Fournier has written, "the majority of these in reality were not legal or physically consolidated" and thus were not protected from cuts by loggers or farmers. Mario Boza explained in an interview with David Rains wallace that the problem was that the forest reserves were managed by different guidelines. "It's a big mistake to try to manage a forest that doesn't belong to you," he said, "[p]arks have worked because we [SPN] own them, and because the Park Service has a clear mandate to protect land, while the Forest Service has a lot 39

of other responsibilites."

In another attempt to address the forestry crisis Costa Rica 
hosted a variety of conferences and symposia during the oduber years to seek ideas and solutions to the problem. In April of 1974 the Ministry of Agriculture sponsored the First National Congress on the Conservation of Renewable Natural Resourcs. Budding conservationists like Adelaida Chaverri, Alfonso Mata, and Sergio Salas (whom Mario Boza had sent on the national parks tour of the United States a few years earlier) were active participants. Members of the Congress resolved, among other things, that increased education and distribution of information on the harms of forest (and other natural resources) abuse would be the most effective cure to the environmental problem.

On a regional, international level two other important conservation conferences took place in costa Rica in 1974. The first was promoted by the United Nations to involve Costa Rica in the UNESCO Man and the Biosphere (MAB) Program as a way of preserving forest resources. A committee of dedicated conservationists including Mario Boza, Gerardo Budowski, Luis Fournier, Rodrigo Zeledón, Rolando Mendoza, and others formed to consider Costa Rica's role in the UNESCO program. Their work culminated in the early $1980^{\prime} \mathrm{s}$ and $90^{\prime} \mathrm{s}$ with the creation of La Amistad International Park (connected with Panama) and the designation of an amplified extention of Braulio Carrillo National Park as MAB reserves. In December of 1974 Costa Rica hosted the Central American Meeting on Management of Natural and Cultural Resources. Costa Rica's delegates included Gerardo Budowski, Adelaida Chaverri, and Christopher Vaughn. A variety of national and international 
conservation organizations participated at the event and discussed ways to curb deforestation and protect natural resources.

A more significant conference convened in November of 1976 that looked broadly ahead at a variety of important cultural and social issues--including the Costa Rican environment. The event, the Symposium on Costa Rica in the Year 2000, was sponsored by the government's Office of Planning and Economic Policy to gather leaders together to present papers and to have round table discussions. President Daniel oduber addressed the forum and emphasized the need to protect natural resources for future generations. In a presentation entitled "Natural Resources," Jorge Manuel Dengo, a former Vice President of Costa Rica, argued that Ticos were "living for the day and without much worry for what's coming. . we show very little concern for the future consequences of our present actions." He complained that legislation regarding mining, forests, water resources, wildlife, and other environmental matters was "disperse" and "passive" and did not "follow a direct policy that linked exploitation of natural resources with the processes of economic development.. . for the potential wealth of the country." He concluded that "the impacts that have been caused to the biosphere and to human societies" could only be corrected by a "well directed policy to balance economic development with the rational management of resources in one ecological-environmental-social system."

While Dengo's stance was an obvious voice for strong, centralized authority for natural resource protection and was overt- 
ly cloaked in a utilitarian, multiple-use philosophy, other participants at a round table discussion on environmental concerns expressed the need for more scientific knowledge on the subject and the need for stronger conservation measures. Rodrigo zeledón (a noted parasitologist and conservationist) argued that more investment be put into human resources for ecological investigations. Anthropologist María Eugenia Bozzoli asserted that the expanding cattle industry was thwarting conservation measures and that any national economic benefits gained from export oriented livestock production would soon be surpassed by the ecological disadvantages it caused. Mario Boza agreed and forecast that the only forested areas existing in the nation by the year 2000 would be those in national parks. He spoke very strongly in favor of increased environmental education as a way to sidestep the otherwise imminent scenario. Luis Fournier approached the dilemma by suggesting that balance could be achieved between conservation and economic development but not without a good deal more re42 search on the interconnections first.

It was also in 1976 that the Consultative Commission on Natural Resources was formed to study conservation issues and to formulate a plan of action for the long range welfare of Costa Rica's forests. Composed of Alvaro Ugalde (who took a six month leave of absence as head of the national parks office to be the commission's technical coordinator), Mario Boza (an advisor to Ugalde and the commission), Rodrigo Zeledón and Pedro León (biologists from the University of Costa Rica), Oscar Arias (an econo- 
mist and future President of Costa Rica), and others, the commission proposed establishing the Instituto de Recursos Naturales y Conservación Ambiental (INDERENA). In a 129-page bill prepared for the Legislative Assembly, the commission granted INDERENA a broad range of duties and powers that would centralize the government's authority in preserving forests. The document outlined how INDERENA would have the power to formulate national policy on natural resources and environmental conservation, supervise policy enforcements, plan specific national forestry programs, promote the study and research of conservation issues, create and execute a National Plan for the Protection of the Environment, and continue to propose laws to the Legislative Assembly among 43

other responsibilities.

President Oduber supported INDERENA but it was Alvaro Ugalde's job to promote it to the Legislative Assembly. In a report to the diputados urging their approval, Ugalde wrote that Costa Rica was suffering from "galloping deforestation." "The work we have in front of us is titanic," Ugalde admitted, and suggested that INDERENA would be "the best solution for the environmental problems of the country." And as if anticipating that the legislators would question why yet another government agency was needed, Ugalde explained that although the current institutions were good, their work was not enough to meet the current environmental crises. The General Forestry Directorate (DGF) within the Ministry of Agriculture, for instance, was "unable to complete its functions," Ugalde contended in his usual manner of not beating 
around the bush, because it lacked "resources, organization, and power." Therefore, because the DGF was "a very small organization for a very large task," it was necessary to create "a superior institution"--or, if you will, to do the INDERENA.

Despite Ugalde's persuasive ways and President Oduber's endorsement, INDERENA did not survive the Legislative Assembly. Finances, disagreement on the necessity of establishing a new agency, and perhaps the diputados' lack of sensing the gravity of deforestation problems in the mid-1970's, defeated the proposed bill. In a letter to a USNPS official in the United States, Ugalde expressed his disappointment and related how "the [INDERENA] commission, as it was expected, never met again." Ugalde returned to his post at the national parks headquarters "to give the battle for Corcovado, the familiar new national park in the Osa Peninsula" and to deal with other park concerns. Forest reserves (or national forests) remained in the domain of the DGF until the agency reorganizations of the mid-1990's (SINAC). For his part in vitally assisting conservation efforts and specifically for his determination to decree Corcovado National Park in the face of so many odds, President Daniel Oduber received the coveted Albert Schweitzer Award from the world wildIife Fund in 1976. A letter to Oduber from Rhena Schweitzer Miller announced his selection for the award and many people and conservation groups from all over the world sent letters of congratulations. He also was the recipient of the New York Botanical Garden's 1977 Green World Award for his "outstanding leader- 
ship in preservation and protection of the natural environment." In presenting the award to him, Howard Irwin, president of that organization, said that oduber had "displayed great courage" in working to create Corcovado National Park and that "his bold action is not only to the credit of Costa Rica, but should serve to inspire leaders of other countries to follow suit." While in New York accepting the honor, oduber also addressed the United Nations and spoke against international military spending, the absence of which in Costa Rica helped to ensure funds for conser46 vation and social programs.

Nine new protected areas (nearly 350,000 acres of land) were added to the Costa Rican national park system during Oduber's term in office. In a 1986 interview with Andrew Reding, the former president reminisced about his role in conservation:

As a socialist ( I am a social democrat), I believe nature's beauty is for everyone to enjoy, not just a few. I have emphasized conservation in order to afford future generations of Costa Ricans the pleasure of enjoying the nature I enjoyed as a child and adolescent. To this end, I labored to set aside not only national parks but also forest preserves and wildlife refuges all across the country. . . . It is of global interest to defend all the treasures we have. . . So mine is a global conception of the role of Costa Rica in the world. We're very small, but we can be an example, like Switzerland, Austria, and the Scandinavian countries, of a society that struggles for peace, justice, and beauty. (47)

Alvaro Ugalde perhaps best summed up the President's support when he said that oduber "became aware that conservation could be a very good political issue." "He never said stupid things about conservation," Ugalde continued," [y]ou heard other politicians 
say things that didn't make sense, but oduber always made sense." When Oduber's term of office was over in 1978, however, many people wondered if harmony between conservationists and the office of the President would be a thing of the past. The new President, Rodrigo Carazo Odio who represented a coalition of opposition political parties, survived a vicious election campaign and was soon to face an economic crisis that would test conservation policy and other social services to their very core. But, as we shall see, environmentalists' worries about his administration would be ill-conceived. David Rains Wallace goes so far as to suggest (wrongly) that Carazo "didn't share Oduber's en49 thusiasm for conservation." How in fact conservation measures dramatically increased during a time of severe economic crisis during the Carazo years warrants attention here. 


\section{CHAPTER 6}

\section{CONSERVATION THROUGH CRISIS}

No la vimos como una tragedia; la vimos como un desafío. (We didn't see it as a tragedy; we saw it as a challenge.)

"Obstacles Became Opportunities:" The Economic Crisis and the Carazo Administration

The Costa Rican national park system was in its first decade of existence when it faced serious cutbacks and restrictions due to the severe economic crisis that hit the country in 1979. Characteristic of most of the Latin American world, Costa Rica went into deep financial debt as a result of overextended loans from international banks. Unable to service the notes, Costa Rica soon became one of the seventeen most highly indebted nations of the world and had the highest per capita debt in Latin America. Much of the problem had to do with factors outside of Costa Rica due to the international economic recession of 1979 that was partially a result of dramatic increases in oil prices. The recession spurred high interest rates in the world capital market and a decrease in prices for traditional products that Costa Rica had to offer. One study explained this scenario as "low aggregate value of national agricultural exports in contrast to high aggregate value of imported products." The wars in Nicaragua and El Salvador during this same time period weakened the Central American Common Market which further hurt Costa Rican trade.

By 1985 the external debt amounted to $\$ 3.8$ billion (equal to 
$\$ 1,500$ per person in Costa Rica) and was the largest per capita debt in the developing world. For Costa Ricans this translated into spiralling inflation--hovering around forty-eight percent in 1980-82, a doubling of unemployment--from 4.3 percent in 1979 to 8.7 percent in 1982 , austerity measures, and federal spending cuts. Especially hard hit were the budgets of environmental management agencies like the General Forestry Directorate (DGF) and the National Park Service (SPN).

Despite budget cutbacks, however, these years were also marked by a significant increase in conservation efforts and national park and equivalent reserve designations. From 1978 to 1982 , the years of the administration of President Rodrigo Carazo, the amount of land protected by law in Costa Rica increased by nearly 583,000 acres or 4.7 percent. At the beginning of Carazo's term there were aproximately 451,000 acres of land designated as conservation areas (or 3.5 percent of the country's land mass) and by the end of the term there were approximately $1,033,000$ acres (or 8.3 percent of the country). Some of the new areas designated included Palo Verde, Isla del Coco, and La Amistad national parks, and Isla Bolaños National Wildlife Refuge. Significant expansions of Guayabo, Corcovado, Manuel Antonio, Santa Rosa, Tortuguero, and Braulio Carrillo national parks also were decreed by President Carazo.

"Keeping a clear vision . . and a conception of priorities" was how the former President described his role in conservation through crisis in an interview conducted for research on 
this chapter. These priorities originated early in his life when he was raised for much of his childhood in a rural, agricultural setting in the mountainous area near Turrialba. It was there that Carazo gained an early appreciation for the land and nature, as he has written in his memoirs, "[t]he rural environment shaped my vocation, my love for family, for the Homeland, and for a great interest in the values of that Costa Rica. . For all of my life." Likewise he has maintained a religious belief in the proper stewardship of the land:

Insofar as our faith teaches us that man was made in the image and likeness of God, we know that the creator gave us an important responsibility: to take

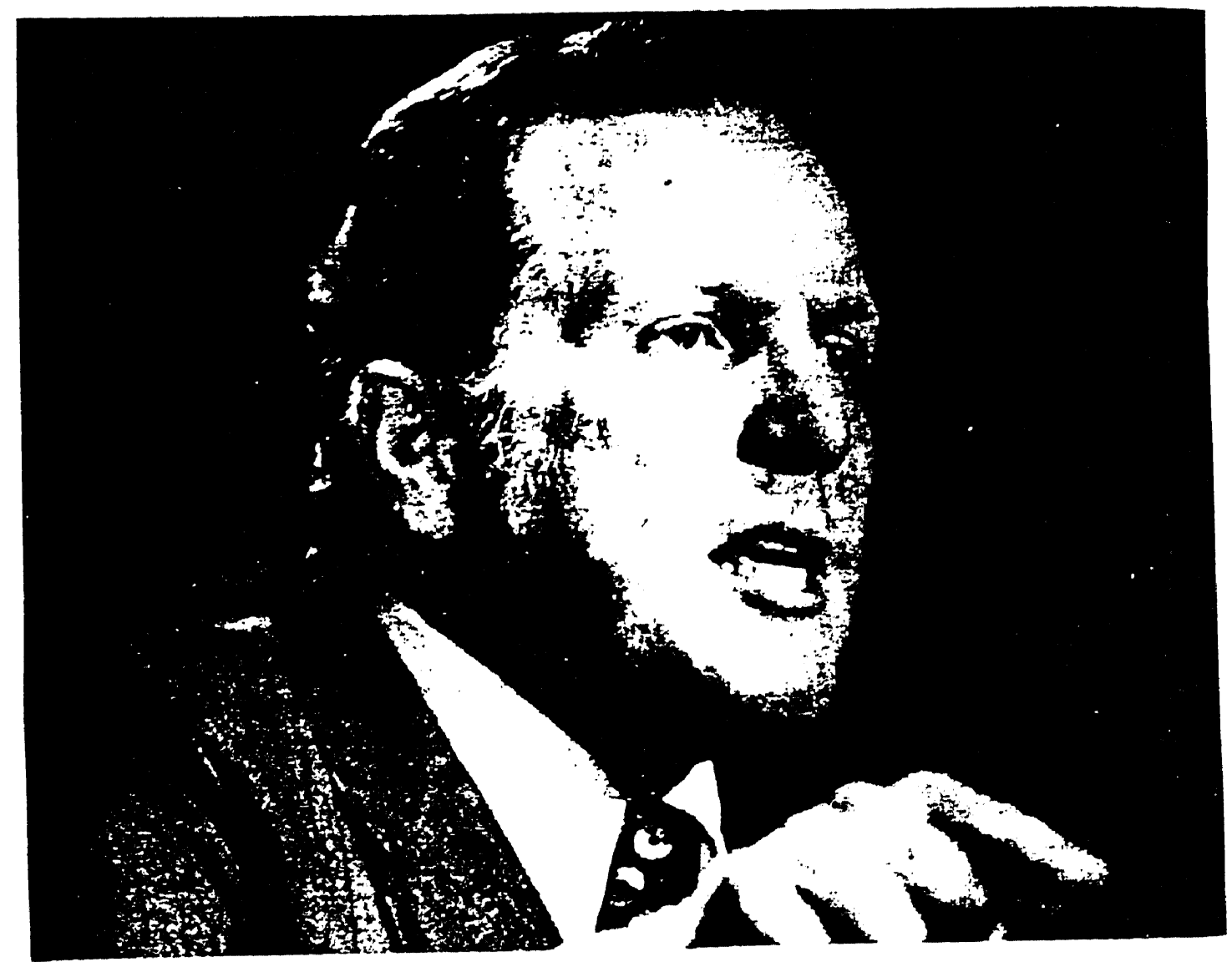

Figure 1: President Rodrigo Carazo Odio (source: Rodrigo Carazo, Tiempo y marcha [San Jose: Editorial UNED, 1989]) 
care of that environment so wisely prepared as our home. Therefore, man's attitude toward nature should be characterized by respect towards all forms of life and the balance between them.

In his term as President during the economic crisis, then, Carazo acted on the values he had learned earlier in life. "I had the fortune that my childhood and youth took place in an environment of hard work, poverty, and austerity," he reflected in his memoirs, conditions that "forged habits in my years as a child that I still appreciate and want to conserve." He also claimed that his interest in conserving forests stemmed from an Arbor Day experience he had as a college student at the University of Costa Rica. For Carazo, saving as many of Costa Rica's natural resources as possible was a means to promote a long-range economic savings for the country. Thus, dealing with the economy (he was an economist by profession) but wanting to continue the government's active commitment to conservation (by then only a ten-year old program), meant taking strong leadership in promoting new parks and making thoughtful appointments to key conservation positions. To the surprise and delight of those who wondered if Carazo would continue the conservation momentum of the oduber administration, Carazo named Mario Boza his Advisor on Natural Resources and retained Alvaro Ugalde as head of the National Parks Service. He also appointed Hernán Fonseca as Minister of Agriculture who generally supported the parks program. Promoting conservation during the economic crisis also meant working closely with private conservation organizations 
("the environmental groups greatly aided my work"), and recruit9

ing financial assistance.

Finances in Costa Rica were definitely short. Carazo was the first Latin American president to suspend payments on international loans. The International Monetary Fund (IMF) thereupon imposed strict austerity measures on Costa Rica and urged quick development of non-traditional crops to market abroad. Choosing "to defend the honor of Costa Rica" and not wanting to impoverish the citizens of his country, as one former staffer put it, Carazo kicked the IMF out of Costa Rica and promised not to devaluate the colón.* In his own words, Carazo emphasized that "there is no internal problem or crisis that should serve as an excuse for a government to submit to impositions made from abroad. . . [and] for this we broke with the IMF and decided to stop all payments on interests and amortizations of the external debt." Fighting for "the respect of our national sovereignty," Carazo was the only president to boot the IMF from his or her country. But although exports were higher during the Carazo years than those of his predecessor (Daniel Oduber)--accounted for by such new crops as pineapples which enjoyed robust external demand; and personal savings, exports, and GNP were all higher than the years of his successor (Luis Alberto Monge)--the country did suffer from a weak economy. Internationally renowned tropical biologist Thomas Lovejoy (who worked with Costa Rican conservationists dur-

* Holding out for more than a year, he was forced to devaluate in 1980 . 
ing the crisis), however, compared this period to the Great Depression in the United states, not only for its financial stress, but also for "recognizing the urgency of conservation projects."

The national park system had its work cut out for it. James Barborak, a national parks planning consultant from the United States who was hired by the SPN to work in Costa Rica in the late $1970^{\prime} \mathrm{s}$ and early $80^{\prime} \mathrm{s}$, posited that the country's economic crisis presented the SPN's greatest challenge to date: "justifying before the public and the legislative powers that more expenses were necessary for acquiring, managing, and administering the areas in its care." José Rafael Mora, the director of Fundación Parques Nacionales (the National Parks Foundation) which was created to help raise and distribute conservation funds, agreed and wrote in a letter to one potential donor that "effective management of existing areas is sometimes as tough a problem as the creation of new ones." And Alvaro Ugalde mentioned in an interview that it was fortunate that many parks were already in existence before the crisis, but to manage them and create new ones during this period was to "transform crisis into opportunity."

The Carazo government did what it could to continue funding the parks program. But while the administration's "enthusiastic support for financing the SNP" was immeasurably helpful, as Luis Fournier noted, inflation reduced the purchasing power of the already cut budgets. One park official recalled that

we lost eighty percent of the buying power of the rest of the budget between 1980 and 1986. After 1980 the first new car that the Park Service was 
able to buy was in 1989. . . There wasn't money even to keep up the old cars, and if they were running, there was no money for fuel, and if there was fuel, there was no money to pay a per diem for the driver to go anywhere. It was really hard to do anything. The Park Service went back to the policies of the first years, trying to offer basic protection to the parks. . . . Some relatively sophisticated public use programs, especially at Poás Volcano, just were abandoned. There was no way the Park Service could keep the same level of attention to visitors. . . . The increase in responsibility was also qualitative because under more severe economic conditions there was more pressure on the parks. (13)

The opportunity that came, then, according to Ugalde, was 14 "to look for money in other places." A fundraising campaign the likes of which the Costa Rican conservationist community had never before witnessed was launched. Nationally, members of Costa Rican environmental groups solicited contributions, donated time, and did volunteer work in the parks. Internationally, many different governmental and non-governmental organizations (NGO's) were tapped for funds and support. A 1979 loan for $\$ 5.5$ million from U.S. AID, for example, was an instrumental source of funds that was targeted to be used for environmental education, soil conservation, reforestation projects, and for forestry and other natural resources management. Similar aid programs in other countries, i.e. CIDA in Canada, SIDA in Sweden, FINNIDA in Finland, DANIDA in Denmark, NORAD in Norway, GTz in Germany, and ODA in Great Britain have worked with Costa Rica and made loans 15 earmarked for conservation causes.

Responses to grant requests from NGO's were equally successful and helpful. Twenty-six organizations from around the world, 
including ones from the United States, Great Britain, Switzerland, and Austria, helped with financial and technical assistance. Groups such as the Sierra Club, Rare Animal Relief Effort (RARE), Caribbean Conservation Corporation, New York Zoological Society, Philadelphia Conservationsts Inc., World Wildlife Fund, the International Union for the Conservation of Nature (IUCN), The Nature Conservancy, and others all financially supported the parks program in Costa Rica during the crisis years. And grant supporting organizations like the Tinker Foundation and the 16 . Rockefeller Brothers Fund made generous contributions.

As a legal way to monitor these loans and contributions, Mario Boza, soon into his new position as presidential advisor on natural resources, believed that a non-profit organization was needed. With the help of government attorneys, he established Fundación Parques Nacionales (FPN) in 1979 as a "private entity with public utility" making it a quasi-governmental body to be funded by contributions and corporate grants. The FPN's bylaws describe the organization's objectives: "to promote the creation, protection, and general development of national parks and equivalent reserves, as well as to promote and develop activities in the field of environmental education and scientific research as it applies to conservation." It also set out to seek grants and to solicit and channel major contributions (corporate or private) for specific conservation causes. Its first board of trustees included Boza (president), Alvaro Ugalde, SPN Assistant Director José María Rodrlguez, and UCR biologists Luis Diego 
Gómez (vice president) and Pedro León. The board hired José Rafael "Rafa" Mora as its first executive director and, by 1982, four other employees. (It had grown to have a staff of twentyfive by 1986.) The first donation came in 1981 from the Caribbean Conservation Corporation for 300,000 colones $(\$ 6,200)$.

The FPN board members learned to be quite creative, direct, and specific in their fundraising appeals. The Animal Research and Conservation Center of the Bronx Zoo, for example, contributed $\$ 30,000$ to help the FPN purchase photographic equipment for an environmental education project in early 1982. A letter from that organization mentioned that "we had quite a visit with Mario [Boza] last week. . . [He's] quite an ambassador." In an FPN update in June of the same year, Rafa Mora reported that the World Wildlife Fund had donated over $\$ 1,100$ for the construction of a new guard station on the east side of Corcovado National Park, the Caribbean Conservation Corporation had given $\$ 9,000$ for Santa Rosa National Park, a private donor had sent $\$ 4,125$ for vehicle restoration and various projects at Tortuguero, and even the Minnesota Nature Conservancy had contributed $\$ 150$ for 18 miscellaneous office equipment.

Mora had learned that requesting funds for specific causes seemed to be a successful strategy in professional fundraising. In early 1982 he wrote to the world Wildlife Fund in Washington, D.C., asking specifically for a $\$ 12,000$ grant to help "start up" the newly-designated La Amistad National Park (building materials, etc.) and $\$ 5,000$ for "urgent equipment needs" in other 
parks. In a grant proposal to NORAD (the government of Norway's aid assistance organization), Mora detailed exact needs and listed specific characteristics of each of the parks for which he was requesting assistance. Corcovado, he wrote, was "the largest piece of tropical rainforest under protection in the western Hemisphere;" Braulio Carrillo was "one of the areas of greatest endemism in Central America;" Tortuguero was "the only area south of Florida protected for breeding manatee populations (and the only [such] area in Costa Rica;" and Palo Verde was "the only area known in Costa Rica with freshwater sponges."

The FPN board also implemented other innovative ideas to raise funds. They sold brochures, books, and t-shirts at national park visitor centers--especially at the most visited park, Poás Volcano. They cleared a profit of over 74,000 colones (approximately $\$ 1,525$ ) from such sales in 1981 . They also considered the idea of creating an "Honorary Members" category for the FPN as a way of honoring individuals who had played such a strong and helpful role in conservation and as a way to show a broader range of support. People on the list included Daniel Oduber, Karen Olsen de Figueres, Gerardo Budowski, Kenton R. Miller, Leslie Holdridge, Archie Carr, Alexander Skutch, Thomas Lovejoy, Dan Janzen, Rodrigo Zeledón, and Jaques Cousteau and other promi20 nent leaders of international conservation organizations. What the fundraising was eventually going for, of course, was the maintenance, upgrading, and expansion of the national park system. President Carazo had made clear that "one of the 
principal objectives of this administration was the completion and consolidation of the wilderness [sic] areas of Costa Rica." To Donald Stone, the director of the Organization for Tropical Studies (OTS), he explained that his work to expand the park system would "give one more step to the best possible conservation 21 of our living resources." His first move as President to begin accomplishing these goals was to decree Isla del Coco National Park in June of 1978 . The park consists of the entire 6,000 acre Isla del Coco--an isolated volcanic island in the Pacific Ocean three hundred miles off of Costa Rica's west coast. It is in many ways similar to Ecuador's Galápagos Islands (and often is called Costa Rica's Galapagos) in that it is far from the mainland country, is home to 140 endemic species of flora and fauna that evolved in isolation, is noted for its rather tame animal life due to an absence of natural predators, and is difficult and expensive to get to. It is also characterized by lush premontane rainforests and palm groves* and is an important rookery for dozens of shorebird species. Coral reefs grace its shores.

Carazo mentioned in an interview that he was particularly happy to have been able to assist in protecting Isla del Coco. He even made a personal trip to the island to dedicate it as a park**--becoming the first Costa Rican president to visit a

\footnotetext{
* One of the endemic plants on the island is the Roosevelt palm (Rooseveltia frankliniana) which was named after the U.S. president who visited Isla del Coco four times between 1934 and 1940 .

** David Rains Wallace (in Quetzal and Macaw, p. 89) relates how Carazo's trip to Isla del Coco was far from a luxurious jaunt:
} 
national park while in office. There was reason to rejoice in its designation; the island has not been without its fair share of troubles over the years. First referred to on a map in 1541, Isla del Coco became a haven for pirates in the eighteenth and nineteenth centuries. By 1793 pirates had introduced pigs and other domesticated animals to run loose on the island. Its supply of fresh water, coconuts, and meat (pigs that thrived there for centuries) made it a favorite stop-over for whalers and pirates who are thought to have hidden valuable treasures in its forests. The pirates Benito "Bloody Sword" Bonito and James Thompson were rumored to have buried large stashes there. Mario Boza has written that "it is believed that more pirate treasures have been buried on this island than anywhere else in the entire world." The government of Costa Rica claimed Isla del Coco in 1832 after it authorized rescuing a crew of shipwrecked Chileans 24 from the area.

A century and a half later, evidence of environmental degradation from these past experiences still exists. Joseph Franke writes that "pigs, cats, goats, and white-tailed deer have all done considerable damage." Pigs, "probably the worst offen-

". . President Carazo and his entourage of 180 dignitaries and journalists had to hire a Panamanian ship to take them to coco Island. The ship never materialized, so eighty of the most favored or persistent pilgrims crowded into a tuna boat and two coast guard patrol boats for the eighteen hour voyage. . . . on the island, according to a Tico Times article, Carazo unveiled a plaque, raised the Costa Rican flag (thus emphasizing sovereignty at a time when war with Nicaragua seemed possible), heard a special mass, and was impressed by the tameness of the birds." 
ders," he explains, "loosen so much soil in the process of rooting for food that they have been implicated in causing the death of coral on some of the reefs" (due to erosive run off). Cats are also a problem ("they kill and eat anything that moves") and introduced flora such as coffee plants and guava trees "replace the less aggressive native understory plants." Franke also cites how illegal fishing has been a problem, "depriving nesting seabirds of food and causing other disruptions to the marine ecosystem." Likewise, trumped up stories of hidden riches brought in treasure hunters from different parts of the world which further threatened the overall ecological integrity of the island. According to Boza, over 500 such treasure hunts have been conducted--meeting with very little success; "only a few doubloons have been found to date." And "compounding all of this," Franke writes, "is the lack of money for enforcement (there are currently [in 1992] no guards on the island) and the difficulty of doing even cursory patrols from the mainland." Carazo and the Park Service were well aware of these limitations. Not long after the park was declared, Jorge Astacio, the executive director of ASCONA (Asociación para la Conservación de la Naturaleza)--Costa Rica's largest environmental group in the 1970 's and early $80^{\prime} \mathrm{s}$, wrote to the SPN saying that Isla del Coco "offers a series of interesting situations for those persons who are lovers of nature and especially for those who have nondestructive research interests." Therefore, ASCONA recommended "a very controlled and limited number of visitors to the island" 
to maintain its pristine environment. The SPN agreed and created such guidelines, but the budget cuts caused by the economic crisis forced the government to replace its park guards on the island (who were needed in parks on the mainland) with Public Security guards (paid out of a different budget). This change did not go over well with the leading tourist company in the country (Adventures in Costa Rica) which planned well-regulated, guided tour experiences of the island. Its president, Michael Kaye, wrote directly to President Carazo complaining that when Isla del Coco was guarded by SPN personnel they were "great-clean, welcoming, etc." Now with the Public security guards his clients were met with "dirty, inattentive, unwelcoming, and uncaring" employees which caused Kaye to wonder if they were responsible to enforce the important island regulations for the fragile environment. Carazo responded indicating that he had turned the matter over to both the Minister of MAG and to the Minister of Public Security expecting action to be taken and for the problem to be resolved. Carazo also received a letter from Luis Diego Gómez at Fundación Parques Nacionales expressing his appreciation to the President for the way in which he had handled "the delicate situation." And Carazo was obliged to turn an earlier Isla del Coco concern over to the SPN when he received a letter from an elderly European man (he did not list his country) named Erdal Osturk who had requested to live his final days and die on the island. The request was denied by the Park Service, citing 
national park statutes which disallowed such park use.

The question of treasure hunting, however, has not been as easy to dismiss. In the summer of 1982 the SPN received an especially convincing request for an exploratory expedition to the island from a San José businessman named Fernando Fonseca Calvo. Fonseca explained that a Spanish galleon carrying a cargo of gold that was shipwrecked off the island in 1882 was buried by a dynamite explosion in an earlier attempt to uncover it in 1945. He estimated his "retroexcavatory" project would take from thirty to forty-five days and would be conducted "conforming to all requirements and controls. . . with the goal of protecting the ecological conditions of the place." As per Civil Code, Fonseca promised to fork over fifty percent of what was found to the Costa Rican government, and, rather obsequiously, offered to donate five percent to the SPN because "without any doubt the national parks constitute the future of the country in many aspects." He concluded by stressing that he was "completely sure of the location of the treasure from which the nation and the [Park] Service will derive enormous economic benefits." ${ }^{28}$ He, like all the others, found no treasure.

Despite that fact, ten years after Fonseca's project a wealthy American treasure hunter received permission to proceed with a multimilion dollar search using sonar and ultralight airplanes. The agreement was that not a single tree would be cut or any other disturbances incurred on the island or its coral reef. 
From the start, however, the expedition was shrouded in controversy. The year was 1992, after the SPN had since been moved to the Ministry of Natural Resources, Energy, and Mines (MIRENEM). The problem was that the treasure hunting concession was being supported by the MIRENEM minister himself, Hernán Bravo (appointed by then President Rafael Calderón). According to Jorge Cortés, a University of Costa Rica marine biologist who was involved with this particular issue, there was internal conflict within the ministry (Mario Boza was the Vice Minister) and Bravo wanted the approval process expedited. Thus, he sent SPN director Alvaro Ugalde (back at the helm after being in and out of that office) to meet directly with the Americans at Isla del Coco. Amazed and flustered by Bravo's temerity, Ugalde called on Cortés, whose specialty is in the study of coral reefs, to look over the proposal and assess its environmental impact. In an interview for this chapter, Cortés recalled that meeting with the treasure hunters "was like meeting with the mafia." "These big guys in suits came out," he said, "and literally asked me 'How much do you want." Cortés opposed the plan and other biologists became involved with negotiating the agreement. The result was that the enterprise was to have paid $\$ 100,000$ for the concession to search for treasure. Cortés, however, does not believe that that amount was ever paid, despite Bravo's claim that it was in an appearance he made on television to answer questions about the controversy. The Americans never found any treasure.

As if that was not enough controversy for one little island 
in one year, there was also a proposal for Isla del coco to become more of a developed tourist attraction in 1992. Plans were for a large casino complex to open on the island that would include hotels, swimming pools, and beach access. Karen Olsen de Figueres vigorously opposed such a proposal when she was an atlarge diputada in the Legislative Assembly that year and sponsored legislation against it. She was opposed to the "right now attitude" to get rich quick that was behind the plan and questioned "how much it [would] cost in the long term." The casino plan failed and access to the island today remains very limited (there is no air service). Camping is not allowed--overnight visitors are required to stay on their boat. Thus, Isla del Coco is a remote, pristine national park that Rodrigo Carazo said he was glad to have had a hand in protecting as a "gift to mankind." President Carazo also had a personal interest in designating another piece of land--the El Murciélago ranch in northwest Guanacaste province. By presidential decree on 13 september 1978 he declared the 28,600 acre ranch to be an extension of Santa Rosa National Park. El Murciélago (Spanish for "bat") had been the vacation hacienda of Nicaraguan dictator Anastasio Somoza Debayle who would be ousted from his country in the Revolution of 1979 . The land, near where Somoza's father had owned land before it was expropriated in 1966 to become Santa Rosa National Park, was a sore point for many anti-somocista Costa Ricans, including President Carazo who sided with the Sandinistas in the Nicaraguan conflict. Thus, many legislators, newspaper editors, and other 
Ticos applauded Carazo's move to expropriate the Somoza hacienda. In his words, Carazo explained that he and many other costa Ricans had resented Somoza's "growing investments" in their country and had worried it could lead to an armed invasion from a base at El Murciélago. They had reason to worry. Earlier in 1978 Somoza's troops had crossed into Costa Rica to raid Nicaraguan guerrilla camps and had killed several Costa Ricans in the melee. At that, Carazo broke relations with Nicaragua and called Somoza "a disgrace to Central America." He also upped the number of police patrolling the border to 6,000 members and borrowed 500 Venezuelan rifles, as the washington Post reported, "to fend off 33

Nicaraguan incursions." Likewise, Somoza had already been using his ranch for "periodic vacations," Carazo wrote in his memoirs, "and had been travelling there by air from Nicaragua--before our administration--without completing any form of official immigration authorization." Thus, Carazo continued, "I decided to expropriate his ranch and surrounding lands. . . ; he didn't deserve to be an owner of one square centimeter of our soil." In May of 1979 the Legislative Assembly approved the take-over and later that year, with Carazo's blessing, divided the El Murciélago sector into two parts: a majority of the area would become part of Santa Rosa, and an adjoining part would be directed by ITCO (the land colonization authority) for the benefit of small farmers to settle. Regarding the Santa Rosa extension, Carazo wrote that El Murciélago would "contribute in a great way to the country's conservation of ecological riches for Humanity, and at 
the same time protect resources for an ever closer future. . . ."

Some inherent problems lurked in this official park extension. For one, as José Rafael Mora at the Fundación Parques Nacionales pointed out, "it is physically separated from the main body of the park." And while he lauded it as an area that "protects the superb northern coast of the Santa Elena Peninsula, . . [t]ransportation for park patrols is extremely difficult." Likewise, Alvaro Ugalde and others at the SPN believed that Carazo's expropriation had a hidden agenda outside of conservation goals. Ugalde and Pedro León explained in one interview that El Murcielago actually had been divided up three ways-with the third, smallest part to be utilized by the Ministry of Public Security as a training base for Nicaraguan Sandinistas. Leon added, "they [supposedly the Public Security officials] trained the Sandinistas there and when they decided they didn't like the Sandinistas, they trained the Contras there."

Actually, this scenario fueled a growing discomfort for Ugalde as head of the Park Service in the new Carazo administration. Relations had not started well very early into the term. First, the previous administration had assigned the SPN a new responsibility toward the end of Daniel Oduber's term in office that ended up causing Ugalde a great deal of grief: management of the National zoo (which, but for a few exceptions, is designed to showcase Costa Rican fauna) located in the historic Amón district of San José. The problem was that a free-roaming 
population of whitetail deer (it lived in the zoo's tropical parklike setting and was a popular feature with visitors) got a bit out of control and began grazing on rare plants cultivated by botanists who were planning to move a botanical garden into the park. Ugalde was ordered to do something about the problem and when trapping the deer failed he finally ordered them to be shot. Zoo workers killed fourteen deer just days after Carazo was elected. The press sensationalized the story, some animalrights attorneys took the Park Service to court, and Ugalde was indicted for destruction of government property. But while the jury in the trial that followed found Ugalde not guilty, the zoo case boded badly for starting work with a new administration. Second, and more significantly, the Public Security forces training Sandinistas on part of the old El Murciélago grounds had crossed into Santa Rosa National Park. Ugalde strongly disapproved. "They were using park fences and trees as targets for practice with heavy weapons," he recalled later, "I got the feeling we were losing the park." Frustrated that it would prove to be a bad precedent and that the situation was growing worse ("the authority of the Park Service had deteriorated to the point that even the park superintendent needed permission from the police to move around the park"), Ugalde wired the Minister of Public Security with a typically succinct message: "Your soldiers are destroying Santa Rosa National Park. The area is under the responsibility of the National Park Service and I ask that you get them out of the park." 
The telegram caused rockets to fly at President Carazo's Cabinet meeting that, unbeknownst to Ugalde, took place that very afternoon. "I was later informed that I was accused of being unpatriotic, or some sort of traitor, and that I should be fired from the Park Service," Ugalde told David Carr in an interview in 1981, "what saved my skin was that. . the minister of agriculture, was very supportive of his staff... [and] told the Cabinet that even though he didn't approve of my words in the telegram--imagine using the word 'soldiers' in Costa Rica--he knew that I was only doing my job of defending the park system." Fortunately for Santa Rosa, the Public Security personnel and the Sandinistas left the park, but it was at the expense of frayed re39 lations between Ugalde and Carazo. And once again, Santa Rosa was at the heart of controversial policy-making (the fifth in a series of scandals if we are keeping track from Chapter Four, see also Appendix 3). The turmoil was enough to make Ugalde think it was time for a change. Soon thereafter, he took leave of his position to begin doctoral studies at the University of Michigan. The new acting director of SPN was a very capable José María Rodríguez de la Guardia, an architect by profession, who had been the Assistant Director of SPN for two years under Ugalde. Around the time he left, ugalde voiced his frustrations in a letter to a friend at The Nature Conservancy lamenting that "it seems not much could be accomplished during this administration." For the record, quite a bit continued to be accomplished on the conservation front in the next two years of Carazo's term. 
The year 1980, for example, marked the tenth anniversary of the Costa Rican parks program. To commemorate the occasion, on February 5 Carazo hosted an anniversary ceremony at the Casa Presidencial. Guests included Dona Karen Olsen de Figueres, former President José Joaquin Trejos, former Minister of Agriculture Guillermo Yglesias (who had been so instrumental in promulgating the Ley Forestal), and other officials and members of the public and press. More importantly, Carazo's commemoration of the anniversary included an executive decree that expanded Guayabo, Manuel Antonio, Corcovado, and Tortuguero national parks--adding approximately 37,000 acres to the park system. Each expansion added vital wildlife habitat, fragile ecosystems, and important 41 watersheds to be protected under national park guidelines.

Toward the end of his term in office, Carazo also signed a proclamation that would greatly increase the size of Braulio Carrillo National Park. With the San José-Guápiles road project under way through the mountains of Braulio Carrillo, some conservationists were dissatisfied with the amount of land that was to be protected and began lobbying for its expansion. The organization for Tropical studies (OTS) entered the campaign as a way to create a biological corridor from Braulio Carrillo to its La Selva research station just north of the park. To do this, the government would have to buy out several landholders' properties. But with few funds readily available, and with the urgency of protecting the area as quickly as possible looming over him, Carazo used a different approach to achieve the end result. 
Recognizing the need "out of an intimate sympathy with the cause," as a Carazo staffer later put it, the president declared the area in question a zona protectora (a temporary legal status protecting the area against any property changes or development schemes) until the oTs could start a fundraising drive for the corridor. The OTS had been working with UNESCO to designate the region a World Biosphere Reserve and, as Carazo explained in a note to his Minister of Agriculture, Hernán Fonseca, the "zona protectora" status would freeze the area until those details and finances were worked out. He also solicited the assistance of his Minister of Justice, Elizabeth Odio Benito. "Given the urgency for immediately and adequately protecting this important zone that has a treasure of natural resources," he wrote in a memorandum to her, "I'm asking for your maximum cooperation in preparing all of the legal documents necessary for 42 this project."

The MacArthur Foundation came up with a one million dollar matching grant which was met by a combination of sources that included the OTS, World Wildlife Fund, Fundación Parques Nacionales, The Nature Conservancy, and the Costa Rican government. By the last six months of Carazo's term, as Luis Gómez of the FPN reported to the president, the challenge had been met and the expansion of Braulio Carrillo was made possible. David Clark, the director of the OTS, hailed the campaign as the "largest international conservation program in Costa Rica up to that date."

In June of 1980 Carazo designated 23,400 acres of lowlands 
along the Tempisque River in southern Guanacaste as Palo Verde National Park. Abutting the Rafael Lucas Rodriguez National Wildlife Refuge that had been declared by President Oduber, Palo Verde was a unique park in Costa Rica in that it represented the largest, and most threatened, system of seasonal wetlands in the country. It is home to over 250 species of birds, has one of the highest concentrations of wintering waterfowl in the region, and supports populations of rare storks, ibises, and spoonbills. In his decree protecting the area, Carazo listed four principal objectives of the park: 1. To conserve the increasingly scarce tropical dry forest of Guanacaste; 2. To preserve "a place of particular importance for the conservation of migratory and resident birds . . . one of the richest areas of avifauna in the country;" 3. To protect the area "diverse in its wildlife and one of the last refuges for animals that still exists in the province of Guanacaste;" and 4. To represent the various ecosystems of great floristic diversity . . . and the forests of the palo verde tree" 44 after which the park was named.

By the end of Carazo's term, Palo Verde National Park was to be clouded in a regrettable presidential controversy, as will be discussed in detail below. But before his term expired, the president worked to leave a final conservation hallmark of his administration: the creation of the International Park of Friendship, La Amistad. The expansion of existing parks and the creation of new parks like Palo Verde, important as they are for their significance in working to protect vital ecosystems, pale in comparison 
to the size and importance of Carazo's last park project. The creation of La Amistad, approximately 500,000 acres of tropical wilderness in the Talamanca Mountain Range of south central Costa Rica (see map, p. 75), nearly doubled the size of the entire national park system. It was established in April of 1982 (soon after Luis Alberto Monge had been elected president but while Carazo was still in office) as an "international park" with Panama on whose border it adjoins. It was the first such park in Central America and the first area to be declared a World Biosphere Reserve by UNESCO (Man and the Biosphere Program) in the Central American and Caribbean region. Calling it the "pride of the nation," Carazo was pleased to play a role in this historic undertaking and remarked in his memoirs that "Costa Rica had brought forward, with great effort, a fundamental wealth for preserving the planet and humanity . . . and assumed the position to challenge other nations of the world to conserve the human habitat." La Amistad's official designation was a long time in the making. The idea of having a world Biosphere Reserve in Costa Rica originated in 1974 when a representative of UNESCO visited the country and met with a committee made up of Luis Fournier, Mario Boza, Rodrigo Zeledón, Gerardo Budowski and others to consider the proposal. The plan continued to evolve with the idea of making it a bi-national friendship park later that year at the Central American Meeting on the Management of Cultural and Natu46 ral Resources. For the next four years, however, the plan lay dormant. "I don't know why it took us so long to create it," 
Alvaro Ugalde later remarked, "I guess we were just too busy with Corcovado and other things." James Barborak, the American parks consultant who was hired by the SPN in 1979 and was instrumental in working with different leaders on La Amistad, suggested that part of the delay was due to the environment itself of the Talamanca Mountains--the rugged terrain, the lack of roads and maps, the difficult conditions for planners to work in. "We went into areas so rough that we had to use horses to help get the jeeps in," he remembered, "[i]t was the only place where I've seen swamps on hillsides."

Nonetheless, in late 1978 President Carazo met with a water users association in southern Costa Rica to discuss ways of protecting the Talamancas' important watersheds and rekindled the idea of creating an international park as a way to help accomplish that goal. Soon he was meeting with various officials from the Republic of Panama to start hammering out the details. Barborak recalled that it was exactly at this same time, however, that "all those coups and changes in government began in Panama." Carazo (who Barborak described as someone who "liked the idea of these border parks--he's a very peace-oriented man"), was not deterred and ended up signing similar agreements with three different governments in a short period of time. By March of 1979, Carazo and Panamanian President Aristides Royo signed the final agreement. It proclaimed (rather loftily, as diplomatic agreements tend to do) La Amistad Park to be "a symbolic gesture of the excellent relations of friendship and fraternity between the 
two peoples and governments, of the high scientific and ecological value of the region, and of the necessity of conserving and preserving the flora and fauna. . . to maintain the area's ecological balance. . . and hydrologic resources."

The next step was in organizing a series of meetings and workshops to develop a scheme for the development of the park. Mario Boza, as President Carazo's natural resources advisor, was a key figure involved. He met with officials from the SPN, OFIPLAN (Oficina de Planificación)--the government's financial planning office, and with representatives of the Panamanian president's office and the Panamanian Institute of Natural Renewable Resources. Next, the Tropical Science Center (TSC) was tapped to survey park boundaries and to conduct research on the flora, fauna, and ecosystems of the entire region. CATIE (Tropical Agronomic Research and Education Center) was contracted to study the planning of park services and instalations. The TSC and CATIE studies were Completed by September 1981 and were financed by OFIPLAN. However, because of the economic crisis and the devaluation of the colon right at the time this research was performed, OFIPLAN had only about one fifth the funds that originally were to have gone to the La Amistad project. But once again, the problem was seen as a challenge. The opportunity opened up for university students to help with the work that needed to be done and to earn college credit for it. According to Barborak, the park planners "got a whole team of university professors and students to do the field component of many of their basic biology 
courses in [La] Amistad."

They could not have chosen a better place for hands-on ecological experience. The Talamanca Mountains embody eight of the twelve Holdridge life zones. They are home to 215 species of mammals, 250 species of amphibians and reptiles, 115 species of fishes, and 560 species of birds. They represent one of the most species-diverse and species-rich places in Central America for vascular plants. What the area is not good for, however, is any form of crop cultivation. There are just too many steep slopes and too much inadequate soil to support agriculture--facts readily advanced by park proponents and planners.

Another component to the research on both sides of the border was concerning the indigenous peoples who lived in that part of the Talamancas that was soon to be declared a park. The mountainous area is where Costa Rica's largest number (over 10,000) of native peoples, including Guaymis, Brunkas, Cabécares, and Bribris, live and work--many still in traditional ways. Subsistence agriculture, hunting, and gathering are mixed with smallfarming ventures in the lower lands outside of the mountains by 52 the majority of these Indians. Barborak stated that the park researchers depended on the Indians to guide them to uncharted areas in the mountains where they needed to survey and collect ecological data. What they often found, surprisingly, were nonindigenous squatter settlements in remote areas--adding to the problems they had to confront to create the park. The govern- 
ment, with the cooperation of the native peoples, established a series of indigenous reserves around the perimeter of La Amistad, but as Barborak pointed out, "they made a bad mistake by not talk53 ing to the non-Indians in the area too."

The end product of all the research was a forty-nine page inventory of La Amistad's natural and cultural resources, socioeconomic characteristics, and a proposed management and development plan to make the area into a national park. Problems addressed in the study included intense deforestation, accelerated colonization in areas inappropriate for agriculture, increasingly worse erosion, and environmental pollution. A host of different government agencies (i.e. ITCO, OFIPLAN, SPN, DGF, ICE [electricity commission], and CONAI [commission on indigenous issues] in Costa Rica, and the National Cultural Institute and RENARE [General Directorate of Renewable Natural Resources] in Panama) 54 all had a hand in finalizing the study. Financing the development of the park would be the next chore. Part of the responsibility for seeking funds again fell on the Fundacion Parques Nacionales since government money was really not available. A letter to the World Wildlife Fund from FPN director José Rafael Mora illustrates quite well the degree of need at the new park: The National Park Service is sending two employees together with two from the General Forestry Directorate. . . Since there are now no facilities, everything from tents and sleeping bags to medicines and horses will be needed. The rangers will have to build lodging, cut trails, and literally create the park from the ground up. . . . We believe the WWF can make an extraordinary difference now. (55) 
Finally on 4 April 1982 President Carazo signed the executive decree that officially inaugurated La Amistad International Park (the section in Panama is simply called Amistad National Park). The presidential decree stated that the park was located in one of the "richest areas in the country for flora, fauna, and potential hydroelectric power." Carazo hosted a press conference to mark the occasion and had various dignitaries speak. Murray Silberman (who had replaced Mario Boza as the President's natural resources advisor) shared that "the precipitous, uninhabited, unclaimed area has been expropriated at no cost to Costa Ricans." He went on to suggest that the park was home to "many plant and animal species in the area that have never been identified, and could well be of great use to man" and that the park could be 56

"a tourist draw on a par with Kenya." But the fact that the park overlapped into Panama caused reporters to question the president more on the political situation of their neighbor to the south than they did on conservation in the Talamancas. Gerardo Budowski recalled that carazo ended the press conference "by begging them to ask him something about [La Amistad] after a half-hour of answering questions about Manuel Noriega."

Soon thereafter, Carazo and a bevy of officials and reporters made a trip to La Amistad to visit the area and, similar to the presidential visit to Isla del Coco, conduct a brief on-site ceremony. Helicopters and jeeps were used to transport the roughly one hundred guests to the remote national park. While there, Carazo met with Guaymi caciques and viewed first hand 
the terrain and landscape of the newly-designated park.

The international conservationist community rejoiced at the news of La Amistad's inauguration. Letters of congratulations poured into the Costa Rican government from all over the world. A list of such correspondences in SPN files shows letters were sent from Prince Philip of the United Kingdom, U.S. Secretary of State Alexander Haig, the chief of the United Nations Environmenmental Programme (UNEP) in Nairobi, the Director of the U.S. National Park Service, the head of the U.S. Fish and Wildlife Service, the Assistant Director of the U.S. Bureau of Land Management, the Director of the Smithsonian Institution, a national director of the Sierra Club, the President of the Audubon Society, a variety of internationally renowned scientists like kenton Miller (then at the IUCN) and Peter Raven (of the Missouri Botanical Garden), U.S. Senators Mark Hatfield, Frank Murkowski, Alan Cranston, and John Chaffee, and many other persons interested in tropical conservation. Michael S. Kaye, the president of Adventures in Costa Rica, wrote Carazo personally saying that "La Amistad, I am sure, will be recognized by the world as one of the most important protected areas on the planet." And in terms of what it meant for Costa Rica, as Murray Silberman wrote to a colleague in a similar position in New Zealand, because La Amistad "more than doubled the total area of national parks here, we are now, if not number one in the world in this regard, then pretty 59 damn close!" 
And thus did La Amistad not only close out the term of Rodrigo Carazo but it also heralded the end of an era in Costa Rican conservation history. Only a few national parks and reserves would be designated in what was left of the $1980^{\prime} \mathrm{s}$ and in the $1990^{\prime} \mathrm{s}$. In an interview for the Tico Times, Mario Boza stated that "we are moving out of the decade of declaration and into a period of consolidation and refined management of the parks." SPN director Jose María Rodríguez explained that

Before us there remains the great task of consolidating the work carried out in the different parks. It is necessary to conclude payment for land purchases and there are still a lot of ground services which have to be built. But the main preoccupation is the training of our park officials who are directly responsible for the management of these areas. . . . [And] there is a gap in our set of laws which requires an important effort. . . . This is the global planning of the country's wilderness, including all the categories of management. . . no matter which organism be in charge of its administration. (60)

To help with these goals, Mario Boza created an instruction manual for the management and administration of areas within the SPN's jurisdiction. In fact, it was also at this time that the whole way parks were being managed changed directions. Early parks were managed under the guidelines of a "master plan" but, as James Barborak has written, they seemed inflexible to the 61 changing needs of the park. By the end of Carazo's term, then, the SPN required that a "management plan," an individual strategy or planning system, be written for each protected area. The plans began with a philosophical statement on park objectives, detailed the park's resources and how they would be permitted for 
public use, and showed how resources would be conserved for long range protection. They had to include resource inventories, management programs for "integráted development," zoning and border delineations, mechanisms to evaluate and revise plans when necessary, and be printed and distributed for public access. Peace Corps volunteers and officials on loan from the FAO and UNESCO all wrote or assisted in the writing of various park management plans during the low-budget and short-staff years of the economic 62

crisis. SPN Assistant Director José Antonio Salazar further explained the benefits of the new system. In a memo labelled "'crazy ideas' (ideas locas) for exploring new routes for protected areas under our care" that he sent to his boss Jose Maria Rodriguez in late 1980, Salazar urged that management plans be set up for "development in stages." "In the specific case of costa Rica where development conditions are so difficult," he continued, "a slow but sure progress" worked better for park planning. The creation of the plans also produced the beneficial side advantage of getting the employees out in the field more so that they could better familiarize themselves with the area.

In addition to these advances in park creation and management, the Carazo administration was characterized by a variety of other successful projects on the conservation front. In 1979 it backed legislation that provided tax incentives for planting trees and for not cutting timber on certain private lands as a way to discourage deforestation. In April of that year, Costa Rica hosted the two-week, fifty-nation Convention on Internation- 
al Trade in Endangered Flora and Fauna. Speaking there, world Wildlife Fund President Russell Train asserted that "Costa Rica has done more for conservation than any other Latin American country."

President Carazo also became concerned that year about reports of pesticide-tainted run off from banana plantations that was draining into the Caribbean at Cahuita and was starting to destroy the coral reefs. Carazo sent a letter to standard Fruit requesting that the company reduce the run off. But when the superintendent of Cahuita National Park approached the Standard Fruit manager to follow up on the President's letter, the manager is reported to have said, "Do you know what I think of this?," and without waiting for a reply tore up Carazo's letter. It was then that marine biologist Jorge Cortés became involved with the coral reef issue, wrote his Master's thesis about it, and worked "to create a consciousness among the public" about standard's poor stewardship and the ills of environmental contamination. Also in 1979 Carazo took a personal interest in forming a network of biological research stations in the national parks and reserves. In a letter to his Minister of Treasury, he outlined how the research stations could be used by costa Rican university students and foreign researchers. They would also increase the country's prestige abroad among philanthropic organizations with the hope of attracting major conservation donations. According to Carazo, the stations would be "a form of non-extractive natural resource exportation." An important 
event that SPN sponsored that year was a research project on environmental education. The goal of the project was to form ways to use the national parks as tools in the "development of an environmental ethic" among Costa Rica's general public. The project's report maintained that hands-on experience in natural settings would lead to "a better understanding of the relation between humans and the total environment and their responsibility in not degrading it." It was hoped that such a program would steer potential students in the direction of ecological research and would have the long range benefit of a more environmentally 67 sound republic.

One of the events of 1979 that made national and internationnal conservationists the most happy, however, was Carazo's veto of a proposed law that would have endangered marine turtles at Tortuguero. The law would have reduced the Caribbean's protective zone off the beaches from twelve miles to three. What this meant was that sea turtle hunters would have been allowed to harvest turtles in unpatrolled waters in areas where the female reptiles rest during the day after ovipositing on shore. According to conservation writer George Reiger, people from around the world petitioned Carazo to veto the bill. And, as he continued, Whereas many other political leaders would have been inclined to sign the bill precisely because of all the outside (especially American) agitation, President Carazo recognized the dire ramifications of the legislation and vetoed it. Turtle aficionados sighed with relief. (68)

In 1980, the year of the park program's tenth anniversary, 
the government sponsored the First Symposium on National Parks and Equivalent Reserves. The three-day conference was a way to bring together many of the people who had been involved with Costa Rican conservation issues and a was forum to assess the direction in which the national park program was headed. President Carazo spoke at the symposium's opening ceremony and other speakers included Estrella Guier (the director of environmental education at the National Open University), James Barborak (who spoke on park planning), Douglas Cuillard (from the USNPS, who spoke on the role of interpretive services at national parks), Guillermo Porras (from the DGF, who spoke on forestry management), Murray Silberman (who made predictions on parks in the twenty first century), Thomas Lovejoy (from the world wildlife Fund), Gerardo Budowski, and Dan Janzen among other presenters and participants. It was also in 1980 that Carazo inaugurated the Centro de Información y Documentación Ambientales (the Center for Environmental Information and Documentation, CIDA). CIDA was a joint project of the SPN and the National Open University whose principal function is the gathering and documenting of information regarding Costa Rica's natural resources and the environment in general. It provides a data collecting and storing service which is used for environmental assessments, industrial planning, and research for educational projects.

The year 1981 began with President Carazo and the director of OFIPLAN signing a declaration for the creation of a National Council for the Protection and Improvement of the Environment. The 
decree stated that it was the policy of the government to attend to the environment's protection for the "collective welfare" of the Costa Rican people. Thus, the council would be a coordinating and consultative organ" of the government to be made up of representatives of the ministries of housing, agriculture, culture, public works, education, and health, as well as members from the waters users' association and the environmental group ASCONA. The council would then "revise, integrate, and coordinate" national policy on the environment, make priorities, and 70 analyze legislation.

other programs that year included a plan to increase cooperation between the SPN and DGF. Activities to be coordinated included publication of brochures, park guard and general labor projects, forestry research, acquisition of lands, and environmental education. The conservation departments also increased their involvement with Costa Rica's universities. Many different workshops, programs, presentations, and discussion sessions took place in the early $1980^{\prime} \mathrm{s}$. And on a regional level, Costa Rica hosted the Mesoamerican Workshop on Interpretation and Environmental Education in September 1981. The three-week conference, organized by SPN and CATIE, was held at Manuel Antonio National Park and was designed to help conservationists from around Central America learn how to create national park management plans and guidelines. It also served to promote ways of encouraging the development of environmental education and on-site interpretive facilities. Workshop presenters included Mario Boza, James 
Barborak, Adelaida Chaverri, Dennis Glick (from the University of Michigan's School of Natural Resources), Tex Hawkins (then working for the U.S. Fish and Wildlife Service), and other SPN staff. Given the Carazo administration's record for national park designations and expansions and its emphasis on other conservation goals as listed here, it is surprising to read that Alvaro Ugalde told David Rains Wallace for research on his book The Quetzal and the Macaw: The Story of Costa Rica's National Parks that "In the Carazo years, we [the SPN] didn't do much, we didn't get much political support, and we had a lot of trouble. . . The strong political support of Oduber was over." Conversely, Mario Boza and Rolando Mendoza have written in The National Parks of Costa Rica that "Currently [1981] the National Park Service has very wide support from the government of the Republic . . . [which] is demonstrated by many diverse programs, many of which are ideas of the very President, Rodrigo Carazo." They cited Carazo's attention to expanding the park system, increasing ground services, and creating CIDA as examples of his support. Political motives aside, the Costa Rican national parks program not only survived but thrived during the debt crisis of the early 1980's. The crisis certainly challenged conservationists, but as Karen Olsen de Figueres put it when asked to describe those years, "obstacles became opportunities." Surmising that "development is an attitude" and not merely governmental proposals, projects, and agendas, Dof̂a Karen posited in an interview that the historical patterns of conservationist thought in costa 
Rica led to its very ability to withstand the crisis. The vision of certain individuals was instrumental in channeling this course. Among those people, she related, was her late husband "Don Pepe" who by abolishing the Costa Rican armed forces in 1948 provided the means to fund other causes, and who again as president in 1970 designated the first national parks. (She wondered if any of the environmental successes of the past two decades would have been possible if Costa Rica had been supporting a military.) She also listed people like Mario Boza, Alvaro Ugalde, and 1980 's ASCONA leader Alexander Bonilla ("all of whom I love dearly") who never waivered in their diligence to preserve 73 Costa Rica's natural heritage, especially during the crisis. Both presidents Oduber and Carazo would have agreed with Mrs. Figueres on the military vs. conservation comparison. oduber had stressed that very point when he delivered his address to the United Nations in October of 1977. And when asked by a reporter from the washington Post what Costa Rica's secret was for a lack of some of the social problems that were affecting other Latin American nations, especially in view of the country's rapidly accelerating conservation program, President Carazo did not hesitate to answer, "The explanation is very simple. We don't waste money on weapons, so we have resources for other things. The needs of our people come first."

So opposed was Carazo to militarization that he believed Costa Rica would be the perfect host country for an international institute dedicated to the study of peace. His administration 
approached the United Nations in 1979 with such a proposal and the General Assembly approved the University for Peace as an autonomous entity with partial U.N. support. While the school's mission is to teach students from all over the world the ways of non-military conflict resolution, it also has an important environmental focus. Carazo explained in an interview with the world Policy Institute's Andrew Reding in 1985 that the school

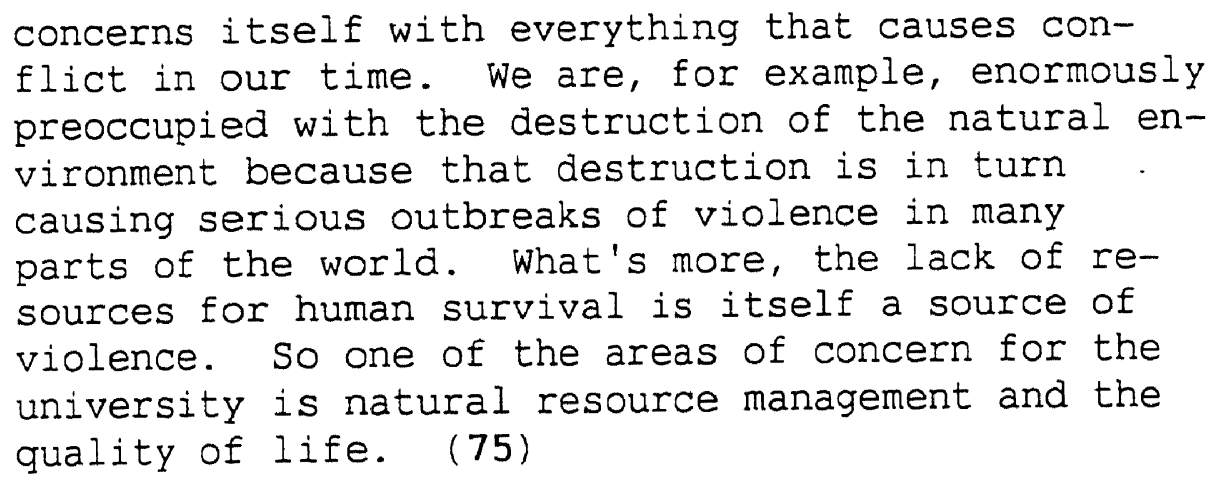

The university is located on land that was donated through an

estate settlement near Ciudad Colon (20 miles from San José)

on a wooded hillside with a vast view overlooking the Central

valley. The campus sits on 700 acres of primarily forested land, 500 acres of which are to be preserved for their aesthetic value 76

and scientific study. The current chancellor, Robert Muller

(formerly of UNEP), is committed to a conservation curriculum

which includes a Master's Program in Ecology and Peace. The

relation between peace and conservation is further addressed in

the university's Basic Documents:

One of the problems which more notably affects international and national peace is that of natural resources. This is the starting point of some of the main problems of misery, injustice, and social tension. . . [ [T]he relation between natural resources and population, sources of food and energy, 
and the conservation of the natural habitat, we consider . . . interrelated and must be approached together within the same area.

For his part in the school's creation, Carazo received the 1981 World Peace Prize from the International Association of Univer77 sity Presidents.

It is the position of this author that Carazo, an economist, understood these concepts quite well and knew what he was doing to help weather Costa Rica's debt crisis despite being severely criticized for his actions at the time and since. The facts are clear, not only on the more visible scale of increased acreage for protected areas, but also in terms of connecting conservation issues with solutions to social problems. The number of precaristas (squatters) on public lands, for instance, was at an alltime high in the oduber administration that preceded Carazo's term--despite a robust economy with low unemployment. Precarismo was more than halved, however, during the Carazo years which unfortunately were characterized by the economic crisis and increased unemployment--conditions that usually result in greater 78 population shifts to public lands. Attention to housing concerns and other urban social issues helped to ease the brunt of the crisis, but standing firm against the IMF also played a significant role. Elaborating on this philosophy, he told Andrew Reding:

The International Monetary Fund obeys the orders of its owners, the developed countries. That is the reality. . . . I don't believe in the IMF because it mainly focused on monetarist issues and not on social questions. . . . As for the world Bank, its representatives came to me with a suggestion while I was president. In response to our foreign ex- 
change problems in 1981, they told us we should stop eating meat, that we should export all we produce in order to obtain more foreign exhange. Had I taken them seriously, there would have been an uprising here. I would have had to tell the costa Ricans, 'Look, we can no longer eat meat. We're going to close all the butcher shops and all our meat will be eaten by the señores of the United States.' How can the World Bank dare to suggest such a thing to a friendly country that has serious problems in this very difficult part of the world? But the policymakers in the Reagan administration don't have the slightest idea what they're doing because they simply don't know us. A very important U.S. official whom I met at a cocktail party said to me, 'Someday I will have to come visit your beautiful island.' I had to tell him that at that rate he would never make it. . . And this was a high ranking official! (79)

And of course producing more cattle for export would have accelerated pasture expansion and deforestation.

Concluding here, then, Rodrigo Carazo viewed conservation as a vital activity within his administration. "The national parks," he wrote in the introduction to Boza and Mendoza's book, are "splendid natural laboratories which we offer to the international scientific community and also to the children, young people and adults who should not be denied the joy of direct contact with nature in its pristine state." And tieing this belief to his concerns for world harmony, Carazo stated that his country's national parks "represent the contribution of the Costa Rican people to peace among men and good will among nations."

The Palo Verde Controversy

There was little peace and less good will among conservationists toward President Rodrigo Carazo in the summer of 1981 . One 
year (almost to the day) from when Carazo had designated Palo Verde National Park near the Gulf of Nicoya in southern Guanacaste, he indicated that he would be "segregating," or withdrawing 9,900 acres from the park (he later upped it to 17,300 acres). The land, roughly three fourths of the total park acreage, according to Carazo had been expropriated improperly by the government--the landowners had not been paid the indemnity due them. The park's creation therefore had violated Article 45 of the Constitution of Costa Rica (regarding "inviolable private property") and Article 22 of the Ley Forestal which concerned compensation for the acquisition of private lands.

Constitutionality notwithstanding, environmentalists inside and out of the government were infuriated. The controversy dragged through the summer and into the fall of 1981 with some interesting twists and turns along the way. The issue itself reflects very well the deepening conservation conviction among Costa Ricans and their willingness to fight for a cause. The literature on the subject, however, is polemical and imprecise. What merits attention here, then, is a review and analysis of the complete series of events as best as possible to understand the controversy in its proper perspective.

At the heart of the matter was the fact that the Tempisque River Basin (where the park is located) is characterized by low marshy wetlands--Costa Rica's largest area for local and migratory waterfowl--but also prime real estate for the cultivation of rice. The land had been owned and operated by various agricultur- 
al conglomerates from Costa Rica, the United States, and Cuba, and with the recession in full swing, Costa Rica needed to produce as many agricultural crops as possible to increase its 82 balance of trade. In July of 1981, when world prices for coffee continued to plummet, President Carazo anounced a "new agricultural policy" that would promote increased production of other crops like beans, corn, sorghum, sugar, cotton, soybeans, African 83 palm oil, fruits and vegetables, and rice.

News that President Carazo was considering separating a part of Palo Verde National Park known as "La Catalina" that could be used for rice farming reached the desk of his natural resources advisor Mario Boza as early as May of that year. Meeting with SPN director José María Rodríguez and SPN attorney Ana María Tato, Boza decided to mount a letter-writing appeal to Carazo with the hopes of swaying him against the decision. Tato's letter of May 25 listed six reasons against splitting La Catalina from the park system: 1. The water basis was needed; if agriculture was permitted in the area, chemicals and pollution would pass through the national park; 2. "It would break the harmony of the ecosystem itself, given that the boundaries are natural and not man-made;" 3. Agrochemicals used for rice production would endanger the area's bird life; 4. La Catalina was a "biogeographical area found nowhere else in the dry Pacific region;" 5. "Costa Rica and its president had been so duly congratulated for their pro-conservation zeal and efforts;" and 6. The split would be contrary to the reasons the park was established. Tato 
signed off her two-page communication by pleading "in the name of

all conservationists in Costa Rica" for Carazo to study the issue 84

and rethink the decision.

Boza and Rodríguez wrote a longer letter to Carazo two days later outlining some of the legalities involved if Carazo segregated La Catalina. First, such a cut would be in violation of the Convention for the Protection of the Flora, Fauna and Places of Scenic Beauty of the American Countries that the Legislative Assembly had ratified in 1966. Article 3 of the Convention declared that national park boundaries could not be "altered." Second, it would be in opposition to Article 76 of the 1969 Ley Forestal that stated very clearly, "once a national park is created, no part can be segregated from it. . without the approvval of the Legislative Assembly." And finally, excising La Catalina would violate Article 13 of the 1977 National Parks Act (which created the SPN), declaring that "the boundaries of the national parks could not be changed except by means of a new law." They then waxed rather philosophical and emotional in stating their case:

Because of the actions that have been completed during this last decade, and particularly during your administration, Costa Rica is an example for the world, and the world has placed its eyes on us. . . . [Cutting the park] would represent a hard blow to the world conservation movement and a very dangerous precedent for our program; it would endanger all the successes we have made up to now. . . . We are sure that the national and international scientific and conservationist community and the public opinion in general are going to react very strongly if the government of the Republic does not follow world tradition and international standards already established. . . . 
As technicians and public officials responsible for safeguarding Costa Ricans' natural heritage, . . we very respectfully request that if the government of the Republic considers Palo Verde National Park to be reduced, that it go to the Legislative Assembly. From a technical and legal viewpoint, this is the only available route. . . . We're convinced that keeping it a national park would bring the best benefits for Costa Ricans in the long run. (85)

The next stop was the Attorney General's office. Ana María Tato wrote Attorney General Manuel Freer Jiménez in June requesting his opinion on the legalities of the question, given both sides were now throwing different statutes and legal clauses back and forth at each other. In his "pronouncement" of June 24, Freer wrote that private inholdings that the state "did not have the capacity to buy" could in fact be excluded from the park designation. Acquistion could only occur via funded expropriation, he wrote. Tato did not accept the decision. Two weeks later she petitioned Freer's office to re-study the case.

Meanwhile, Carazo had decided to proceed with the park segregation plan. On July 2 he issued Executive Decree 12.765-A reduccing Palo Verde National Park by 4,000 hectares $(9,900$ acres) because "the state did not have available the economic means to complete the purchase of, nor the expropriation of, the farms." Coincidentally, the decree came on the same day that Alexander Bonilla, conservation chairman of ASCONA wrote a ten-page letter to Carazo urging him to change his mind. Bonilla was used to park controversies--he had been an SPN technician and a director of Santa Rosa and Poas Volcano national parks. He thus wrote with the authority of both knowledge of Palo Verde's ecology and 
of the interworkings of the Park Service and went more into detail on some of the scientific and legal points that had been expressed earlier by Tato, Boza, and Rodrfouez. Carazo responded in kind a month later with an eight-page letter to Bonilla. In it he explained that the Convention for the Protection of Flora and Fauna also was set up "to respect each nation's judicial laws under which the national parks were created." He likewise re-explained his position on the unconstitionality of the La Catalina expropriations and assured Bonilla that "this administration has and will continue to work on conservation."

Soon after the presidential decree, San José newspapers solicited reactions from members of conservation organizations. Hardly fast-breaking news or front page material in San José, the first paper to run a story on the matter was La Nación on July 6 on page 6-A with the headline "Government Intends to Segregate Palo Verde National Park." The article quoted agricultural minister Hernan Fonseca who spelled out that the government simply did not have the funds to pay the landowners. It also quoted Alexander Bonilla who went into detail about the park's ecological features and the country's conservation laws as reasons why he and his organization opposed the plan. ASCONA's president, oscar Hutt, also made a statement, exaggeratedly proclaiming that President Carazo was "trying to eliminate systematically, by one form or another, almost the entire system of reserves and nation89 al parks in Costa Rica." (Interestingly, near this item in the paper was another article about a legislative committee's approv- 
al of the proposed Cacique Garabito Biological Reserve that Carazo had supported.)

ASCONA stayed in the forefront of the Palo verde matter and led the movement against the administration. By July 9 it had announced that it was considering filing suit against the government if the proposal did not go to the Legislative Assembly. A few days later the group announced it was also preparing a draft bill to send to the Assembly that would require that body to ratify park creations--to reduce the authority of the President. On June 14 La República reported ASCONA's decisions and headlined that "a battle" was brewing "to prevent the government from destroying parks."

On the same day, ASCONA received the well-publicized support of one prominent figure for its Palo Verde battle: ex-President Daniel Oduber. Oduber offered no political niceties when he announced his support for ASCONA. "The childish pretext that there is no money to pay for that part of the park," La Nación quoted him as having said, "is very poor and there are many doubts." He went on to state that Carazo should have known that the park segregation would violate the Convention for the Protection of Flora and Fauna since he (Carazo) was president of the Legislative Assembly the year that body ratified it. He also suggested that the plan would decrease Costa Rica's international prestige and ended his press statement by urging people to ask, "who will benefit the most?" from the administration's plan. Later that month, Oduber (an attorney) expressed interest in assisting 
ASCONA with its legal suit. (On July 29 La Nacion released the results of a poll which showed that a majority of Ticos considered Daniel oduber their "best president" and that Carazo's popularity was continuing to decline.)

The Costa Rican economy also continued to decline as that summer moved slowly along in 1981. By July 15 the colón had been devalued by seventy-four percent. With that in mind, Carazo had a tough choice to make concerning the construction of a government subsidized petroleum refinery (Refinadora Costarricense de Petróleo, or RECOPE) that many people in the nation wanted. The President chose the politically rough, but fiscally sound, route and vetoed the proposal which, according to newspaper sources, would mean the price of gasoline would increase. Carazo justified the move based on the belt-tightening austerity measures the country would have to endure to get through the crisis. On that same day (July 15) and as further evidence the government had no money to spare, Carazo's minister of housing resigned citing a shortage of funds with which to run his department properly. The administration recited these examples as proof it had no funds with which to expropriate the La Catalina holdings.

But an even bigger bomb dropped the next day when La Gaceta (the Legislative Assembly's official publication that prints the laws and decrees of the land after they have been made--no law is a law until it is published here) printed President Carazo's Executive Decree segregating Palo verde. The big surprise for everyone was that instead of the 4,000 hectares he orally announced to 
to be split from Palo Verde on July 2, there were 7,000 hectares $(17,300$ acres) listed officially in La Gaceta on July 16. As one can imagine, the outcry against this news was loud. A La Nacion article stated that there "was severe opposition from conservationists" and that Ana María Tato had renewed her request for the Attorney General to reconsider his earlier pronouncement. It quoted Alexander Bonilla's reaction on behalf of ASCONA and also said that the organization of American States (OAS) and the U.N. had voiced opposition to the plan. It quoted Mario Boza asking of his employer, "What interests are moving behind this new illegality of our current government?" The paper did quote one person who sided with Carazo, Minister of Justice Elizabeth Odio Benito, who reiterated that the "confiscation" of the Palo Verde property without due payment was unconstitutional.

The reduction of national park land was bad enough in and of itself, but conservationists' biggest fear was that the Palo Verde case would set precedent for landowners around other protected areas to press for segregations also. The fears were well founded. On July 17 La República wrote that "the authorization of this segregation has brought fatal consequences for the rest of the parks and reserves." It reported that farmers near five other parks including Barra Honda and Cahuita were clamoring for land to be released. Two days later, SPN director José María Rodriguez explained to reporters that the Cahuita petition, based entirely on the administration's decision for Palo verde, called for cutting 260 acres to be returned to farm land. At that 
point ASCONA officials wasted no more time and sent their National Parks Ratification Law proposal directly to the Assembly. A supportive diputado there (Miguel Angel Chaverría) demanded that agricultural minister Hernán Fonseca explain the Palo Verde decision in person to the Assembly. La Nacion carried the news of these other possible park cuts on the front page--the first such coverage since the controversy unravelled. A few days later, the DGF (Forest Service) received a petition to trim land off the La Carpintera ("The Woodpecker") Protective Zone that was under its jurisdiction. DGF director Francisco Chacón did not 96 allow it--a move that ASCONA was quick to applaud. There was understandably a great deal of concern centered on whether the government would trim acreage off of the Rafael Lucas Rodríguez National Wildlife Refuge, an earlier established reserve adjacent to Palo Verde. The administration, however, made clear early in the controversy that there would be no such plans.

Carazo's delayed revelation regarding the size of the cut at Palo Verde and news that landowners around other parks were petitioning for park reductions sent college students and others to protest in the streets. The day after the La Gaceta notice (July 18), a group of protesters in Ciudad Neilly near the Panama border blocked the road to the airport after President Carazo had inaugurated a new stretch of paved road. His exit temporarily delayed, Carazo spoke to the protesters for over a half hour in a downpour of rain about the Palo verde issue and other concerns. On July 28 , a group of biology students from the University of 
Costa Rica and the National University staged a protest in front of the Casa Presidencial specifically because they opposed the Palo Verde cut. Displaying a banner that read "Defendamos Nuestros Parques Nacionales; ALTO a la Segregación" (We defend our national parks, STOP segregation), the students met with the Minister of the Presidency, José Cordero, who listened to their concerns and promised to relay their message to Carazo. The group also had a "round table" discussion with Mario Boza and Alexander Bonilla to plan what else they might be able to do.

There was other public reaction. A La República article reported that really "no one was in agreement" with the adiministration's proposal. Letters to the editor were sent to all the major newspapers protesting the move. A one-inch thick file of letters is also in the SPN archives from various groups and individuals upset at Carazo's decree. Included in said file are numerous letters and signed petitions from members of the Colegio de Biólogos (Costa Rican Biologists' Association), labor unions, legislative diputados, local school employee groups, enraged citizens, national and international conservation organizations, municipal leaders, sports clubs, and even one from the members of a dance troupe. SPN employees also practiced their rights and wrote letters of protest to their own ministry. One particularly stinging letter was sent by beekeeper Victoriano Hidalgo who lambasted the government for altering the environment in a way that could adversely affect the production of honey. And someone even wrote a poem entitled "Requiem por un parque" 
(Requiem for a Park) lamenting the segregation and the precedent it sets for other parks. No author's name was included, but the poet wrote:

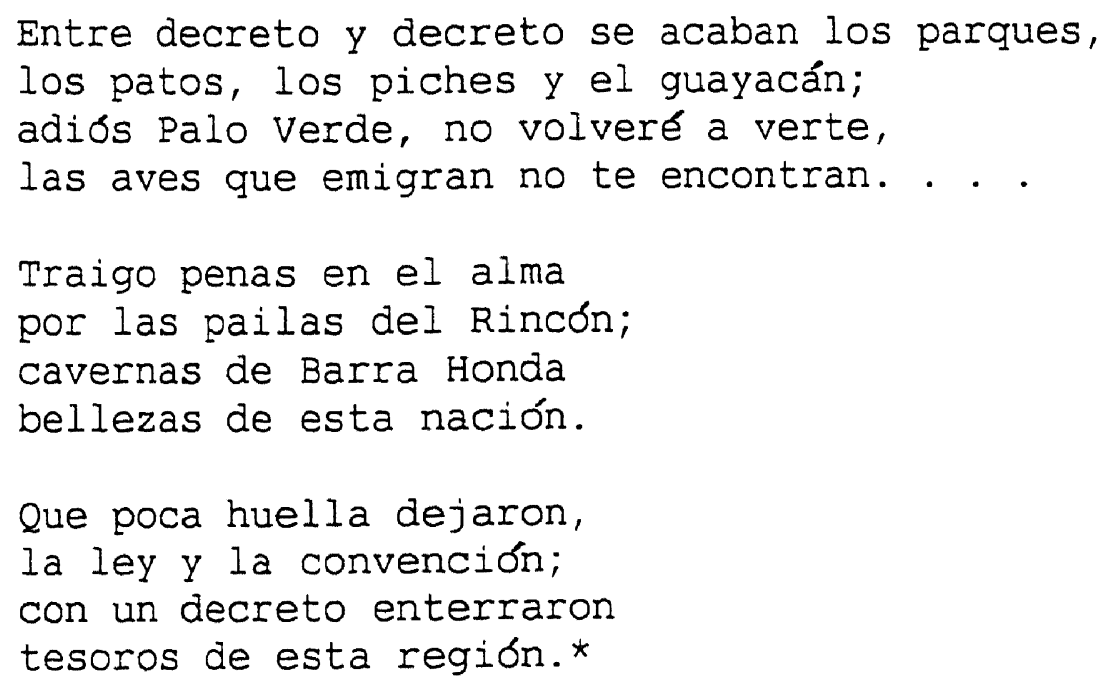

(For the complete poem, see Appendix 4.) It is for good reason, then, that Alexander Bonilla called Palo Verde "the national park protected by public opinion."

\section{0}

There was not much official response to such public outcry. The administration did issue a press release on July 22 in which Carazo complained that many of the attacks on his decision were "unfounded . . . and did not deserve any special comment." The

* transl.: Between decree and decree the parks all die, the ducks, the swans, and the guayacans, good-bye Palo Verde, I'll not see you again, the migratory birds will never find you.

I feel pains in my soul, for Rincón Volcano, for the caves of Barra Honda

for the beauties of this nation.

What small marks were left

by the law and the convention, with one decree they buried the treasures of this region. 
release also quoted Carazo responding to a letter written by

Michael Wright of the World Wildlife Fund assuring that the administration was proud of its conservation record and would continue to do more. In fact, the administration directed the Park Service to draw up a report to document Carazo's conservation record thus far into his term. The result was a paper entitled "The National Parks Program During the Carazo Administration" which listed new parks and reserves and compared the record to that of Oduber's term. (The report showed that Oduber had signed 316,758 new acres into the system while Carazo had approved 572,756.*) Likewise, on July 28 the administration ran a half-page display advertisement in La Nacion proclaiming in bold letters that "El Estado No Puede Aduenarse de las Propiedades Privadas" (the State cannot take possession of private properties). It again stressed 101 the budgetary and constitutional positions.

one particularly enraged citizen was Mario Boza. Surely it must have been difficult to be the President's natural resources advisor during that summer of 1981 and be so opposed to the Palo Verde decision and so at odds with the Minister of Agriculture who supported it. But the La Gaceta notice about the additional acreage to be chopped from the national park was the coup de grace. Boza tendered his resignation on July 22. Both major San José newspapers reported his departure and La República printed his entire letter of resignation. In it he manifested

* of the figure for the Carazo administration, 500,000 acres were from the designation of La Amistad International Park. 
his disgust about Palo verde and his deep concern that the administration's decision was putting in jeopardy seven other parks. "Could you imagine a worse blow to the system of protected areas in the country," he asked hypothetically in his letter to the president, "and could you imagine a more grave precedent against conservation of the country's natural resources?" He went on to assert that very few countries, and none in the developing world, had ever succeeded in completely paying property owners for lands dedicated to conservation. And he closed by stating that he and the many other costa Ricans who had "fought for the creation of the national park system" were in "pain" because of the Palo Verde decree and its attendant bad precedent. Boza returned to 102

his university post at that point. Carazo named Murray Silberman to fill the position of Advisor on Natural Resources. Carazo was uncharacteristically reticent about Boza's departure. The only official response on record was in a letter he wrote to MAG minister Hernán Fonseca which the president's office made public in the form of a press release. The letter does not directly address Boza's announcement but it does allude to its cause and is important here to help decipher the whole situation. Carazo alerted Fonseca in this letter that he had "given the order to purchase" those 17,300 acres of Palo Verde for the coming fiscal year's budget (even though it would be of a different administration since the elections for a new president were close at hand'). Thus, as suspected by this author based on the President's past conservation accomplishments, 
Carazo proved he did want to preserve Palo Verde--the money was simply not available in his budget--and that accusations of ulterior motives, i.e. who or what was "getting to him," were more in the imagination of his opponents than can be found in 103

the historical record.

Meanwhile, two other issues were pending in the Palo Verde situation: the National Parks Ratification bill in the Legislative Assembly and ASCONA's suit filed against the government. The Assembly took up debate on the ratification proposal in late July and early August. While the motion was eventually shuffled off to a committee where it remained for over a year, discussion on the bill was telling. It represented the thoughts and opinions of people, many of whom agreed with Carazo, that did not receive the same kind of media coverage like that of the student protesters and officials from international conservation organizations. Diputado Hubert Rojas Araya, for example, led the cause against the proposal because he felt the President should have the right to adjust conservation policies based on the needs of people. Rising to speak on August 2, Rojas criticized ASCONA's proposal as "absolutely inconvenient" and "an unsolemn [sic] irresponsibility" to attempt including parks and reserves in "one package deal." He went on to state that such policies "affect thousands of Costa Ricans whose land is there one day and taken away the next" and that there had been "hundreds of injustices" of this sort. He said there were still people in his district who had not been paid for their land that the government had ex- 
propriated years earlier. "Let's not do this," he argued, "I 104

know that many in your districts will suffer too."

Diputado Rojas and others also spoke on what they perceived was a dangerous direction in which the budding conservation movement was headed. Because ASCONA and the influence it was starting to have to affect policy was a relatively new concept in

Costa Rica, Rojas enjoined his fellow legislators to be cautious:

I'm not really against ASCONA, but ASCONA wants to make Costa Rica into one big national park. Let's make national parks and biological reserves--but where's the money to pay Costa Ricans for their. land? Or should all the land just be given over to ASCONA? . . All this has come about because of what the administration is doing to Palo Verde. But why? Because the government does not have the money to pay for the whole area. Then comes ASCONA and protests, but I ask where's the money? It's like what happened to the people at Quebrada Honda de Guatosa who have been fighting for eight years for their money. We can't just go in and freeze their land and tell them not to work it anymore. . . Let's give audience to the thousands of affected campesinos. . .

When debate on the floor resumed later that day, Rojas continued:

I'm not against national parks, just the way in which they are created, from the desk of the President. . . I respect ASCONA's philosophy very much, but I can't accept that a Costa Rican who has worked his land for years wakes up one morning surprised to learn that his land has been demarcated and that it's no longer his. . . . I know that many diputados will vote for this because they are against the President, but this is a bad reason, . . . it affects many costa Ricans. . . This is an error we are committing. (105)

on the other side of the issue supporting the Ratification Law was Diputado Chaverría Méndez. He agreed with Rojas that thousands of people were "being evacuated from their lands.. . 
for the creation of national parks and reserves," but argued that it was not being conducted in an irresponsible manner. He also refuted Rojas' point about voting against any one particular president and noted that the law would affect whoever had been elected. Most importantly, he hastened to the attention of his fellow diputados that often, like with the case of Palo Verde, it was not poor campesinos whose land was being expropriated, but rather that of agricultural conglomerates--"millionaire businessmen"--who were often from abroad. In closing his speech, Chaverria quoted from the ecological and legal research performed by Mario Boza and Ana María Tato on the Palo Verde issue and said that he "admired and respected ASCONA" because its philosophy rep106 presented "the majority of Costa Ricans." Rojas' motion won. A year later the bill made it out of committee and was approved by the Assembly. The next president, Luis Monge, signed it into law ASCONA's law suit was, ultimately, not as successful as its legislative proposal. When the environmental group first proceded with its case its attorneys had trouble with Carazo responding to their requests. Nonetheless, a lower court ruled in ASCONA's favor (based on the legalities of the Forestry Law and National Parks Act clauses) and invalidated the President's decree to segregate Palo verde. At that, the administration quickly appealed to the supreme court which reversed the lower court's decision and ruled in the government's favor (on the 107 constitutionality question).

Thus, the trimmed off section of Palo Verde remained sepa- 
rate from the national park for the next few years. But what started as a lengthy, drawn out controversy, ended in a quick and surprising way: the agribusiness landowners donated the land back to the National Park Service by the end of the decade. What the environmental groups, court cases, legislative action, citizens' protests, and international lobbying could not achieve, the rice growers made happen with one single move. The park, now connected with the Rafael Lucas Rodríguez National Wildlife Refuge, is as Mario Boza has written, "one of the most ecologically diverse places in all of the natural areas of the country." What conclusions can be drawn from the Palo verde experience? First, it is safe to admit that it was an unfortunate controversy that tainted the conservation record of Rodrigo Carazo. Alvaro Ugalde's pointed opinion about the administration clearly illustrates this point. The words "Carazo" and "Palo Verde" seem inherently interconnected when researching costa Rican conservation during the early $1980^{\prime} \mathrm{s}$. It was the first response of $\mathrm{kirk}$ Koepsel, the Peace Corps volunteer who worked with the SPN at that time, when asked about those years. However, keeping things in perspective was more of Mario Boza's role when approached on the subject in a recent interview. Obviously not fond of the memories of that summer in which he resigned from Carazo's service, Boza also admitted that the Carazo years witnessed valuable conservation advances. Likewise, he praised Carazo for his accomplishments on peace and other issues that have characterized his 109

post-presidential years. In fact on this regard Carazo shares re- 
markable similarities to the experience of former U.S. President Jimmy Carter who seems to enjoy greater public esteem now than he did during the troubled years of his term.

Second, it is important to question the element of inevitability that seemed to characterize the controversy. That it was avoidable by either 1 . the President's refusal to cow to the agribusinessmen (as the record shows there were other examples of as yet unpaid land acquisitions); or 2. that the landowners could have cooperated from the beginning and saved many people a great deal of grief, is ahistorically hypothetical, but nonetheless realistically possible. The problem, however, is in researching these points--there is simply very little evidence to reconstruct the entire picture. The Park Service and Legislative archives offer no clues and newspaper accounts are basic at best. Journalists of the day did little to investigate the root cause of the dilemma. Obviously, political reasons were not at the heart of the decision--Carazo by all accounts would have gained political popularity points had he backed off his decree.* Euture political aspirations were moot anyhow since costa Rican presidents may not be re-elected to consecutive terms (and this is a good case in point on why not). And, by Carazo's admission, he duly desired to see the area protected--he called for its budget allocation

\footnotetext{
* While the presidential campaigns were starting to rage that summer, it is interesting to note that neither Luis Alberto Monge (who won) nor Rafael Calderon (who lost) mentioned the Palo verde affair in any newspaper advertisements or press releases. Perhaps it was just too much of a political liability either way it was addressed.
} 
for the next fiscal term. Thus we are left with few choices on the decree's motivations, and given the overwhelming preponderance of economic evidence of the timeframe, must consider that the government simply was broke. Making tough, unpopular economic policy decisions like expelling the IMF, vetoeing RECOPE, and excising part of Palo Verde, then, all must be lumped together. Finally, the controversy represents a significant step in the evolution of the Costa Rican environmental movement. It became a rallying point for conservationists and biologists to band together to work for effecting change--experience that would be to their advantage in the not so distant future with other environmental crises. Moreover, it represents a genuine sincerity toward an ecological cause. People were not fighting to preserve their favorite lake to go boating on or some other popular recreational destination; they were fighting to save the country's most important system of wetlands that is home to nearly three hundred species of birds and is one of the most important stopover points for migratory waterfowl and waders. Most of the participants in the movement, to be sure, probably had not ever visited the area. Just knowing its ecological value, however, served as incentive enough to be involved.

Such enthusiasm, it should be noted, at times clouded the good judgment of the conservationists. ASCONA president Oscar Hutt's public accusation that Carazo was trying to ruin the entire park system, for example, did not really help his cause. And Alexander Bonilla tended to exaggerate unfairly when he wrote 
in his essay "Segregación de Parque Nacional Palo Verde" that Carazo was working for the "elimination" of Palo Verde. Bonilla went on to quote Carazo's words of praise for conservation that he had written in the prologue of Mario Boza and Rolando Mendo$z a$ 's The National Parks of Costa Rica (see page 227 above), and wrote "Oh what irony! Judge for yourselves, Costa Ricans. Yes, our environmental history is full of ironies."

The Monge Administration

The debt crisis in Costa Rica hardly evaporated with the election of a new president, Luis Alberto Monge, in the fall of 1981. Monge, of Figueres' National Liberation Party, had promised to work on improving the economy by increasing agricultural production and putting "unused land" to work--a concept that understandably worried conservationists. James Barborak was quoted in an October 15 Tico Times article as saying that "the Costa Rican government has the legislative power to reclaim lands inside parks for development." So because the Park Service wanted no more Palo Verdes, the times now called less for adding new parks to the system and more for improved protection of existing ones. Mario Boza claimed in the article that "We are moving out of the decade of declaration and into a period of consolidation and re111 fined management of the parks."

Continuing in the tradition of the Oduber and Carazo presidencies, Luis Alberto Monge made thoughtful appointments to governmental agencies responsible for conservation. He named Fran- 
cisco Morales as head of the Ministry of Agriculture (MAG) who retained José María Rodrlguez as chief of the SPN. Rodrlguez had been serving as "acting" SPN director during Alvaro Ugalde's graduate school leave, keeping in close touch with him during the absence, but now assumed full directorship duties. Morales had other plans for Ugalde (who had missed the Palo Verde ordeal by being in the United States) upon completion of his studies in Michigan: full time fundraiser for the parks program with an office in washington, D.C. Actually, the idea for the job had come from Geoffrey Barnard of The Nature Conservancy who maintained that Costa Rica's conservation program was developed enough by this time to warrant such a position. The Conservancy worked very closely with Ugalde, the SPN, and the Fundación de Parques Nacionales (FPN) in those days and supplied office space for Ugalde at its washington headquarters. Glad to have a new adminstration, Ugalde sent President Monge and his wife Doris their own separate copies of the book the National Parks of Costa Rica "as a small showing of our welcome." He indicated in a note to the new First Lady that he would like to meet with her to discuss his 112 program of increasing park funding. Meanwhile, Mario Boza continued his work at the National University and became an ever more active president of the FPN. Ugalde in his fundraising position was the FNP's Executive Director.

Fundraising by the FPN was at the center of national parks activity during the Monge administration (1982-1986). "The economic crisis itself was a new lesson," Ugalde later recalled, 
"[n]either could we trust the national economy or the financial system that we had." Thus, while Costa Rica's economy reached rock bottom in 1982-83, the FPN launched a five year 5.5 million dollar fundraising campaign--a drive that made similar efforts during the Carazo years pale in comparison. The goal was to reach three million dollars during President Monge's term alone. In a letter to the Vice Minister of the Presidency, Ugalde alerted the administration to the goal and encouragingly noted, "We think this is doable, we are very optimistic." "However," Ugalde continued, "we will depend on the strong moral support of the President of the Republic and of the government in general." A few months later, Ugalde wrote directly to the President suggesting how "indispensable" it was for him "to show that he and his administration were endorsing our efforts." He also asked him to lend his name to the campaign committee as an honor113 ary chairman. Monge agreed to the request.

In February 1982 the FPN issued an eight point "Priorities Plan" to outline the goals of the fundraising campaign.* At the top of the list was what was to become the FPN's principal focus in the early eighties: acquisition of private in-holdings within 114

park boundaries. It was the in-holdings that were needed to con-

* In descending order of priority, the Plan called for 1. Acquisition of lands; 2. Projects for the administration and improvements of the parks; 3 . Training programs (for park personnel); 4. Research, inventorying, and planning of facilities; 5. Projects for "conservationist and ecological development;" 6. FNP budget funding; 7 . Interpretative service at national parks; and 8. Publications. 
solidate the management of the parks and to better protect their ecological characteristics. José María Rodríguez explained,

By 1982, . . . the [economic] crisis was hitting really hard. . . . [W]e were getting all kinds of pressure from owners of private inholdings in the parks. They all started screaming, 'We want the money! We want the money! or we'll cut the trees in the night! we have the right! we're the legal owners!' Many of them started pushing very hard in different ways: going to the press, threatening to go to court to get establishment of the park declared illegal on their land. We were really afraid of the legal precedent that would set. (115)

Examples of what Rodrlguez was talking about were occurring at Cahuita, Braulio Carrillo, Poás Volcano, and Santa Rosa national 116 parks.

The brunt of this legal problem, as in the case of Palo Verde, fell on the shoulders of SPN attorney Ana María Tato. Decribed by David Rains Wallace as someone with "an almost religious faith in the Park Service's mission," Tato literally worked nights to keep the landowners' demands out of court. She was a "very energetic woman," Rodríguez remembered, "although they [the landowners] made her life miserable." He went on to explain how the landowners would call her at home and threaten her because they had not yet been paid for expropriated properties. Compoundding the problem was that ASCONA had filed suit against the government (specifically against MAG) for allowing private concessions within national parks. The environmental group pressed all 117 the way to the Supreme Court to force expropriations.

The problem was simply financial. Alvaro Ugalde elaborated on the dilemma in a 1981 interview with David Carr of the Carib- 
bean Conservation Corporation (CCC):

The government has had no doubts or qualms in establishing the present system, but it has not been able or willing to provide the funds necessary for land acquisition. That is definitely the biggest part of our . . . expenses. It is very easy to pass a law, to freeze the land, to say 'That's a park,' and for us to send a few rangers to take care of the land. But then what? we probably own about eighty percent of the land in the system, but around twenty percent is private property. (118)

Thus Ugalde's work was laid plainly out for him in his washington office in 1982. By May of that year he had met with a variety of international conservation organizations in washington and New York and reported successful meetings with them. The Nature Conservancy had accepted a proposal to contribute $\$ 320,000$; the World Wildlife Fund (WWF) had accepted one for $\$ 25,000$; and the Rare Animal Relief Effort (RARE) and the CCC were considering similar proposals at the time of a report he made to the FNP's executive board. Gerald Leiberman of RARE, Ugalde noted, had also agreed to help him get an article published in Audubon Magazine to further publicize the need for funds." Later that year, OTS director Donald Stone informed Ugalde that his organization had come up with $\$ 50,000$ to help with the zona Protectora land

* All fundraising appeals were not equally as successful. In 1983, for example, the OTS turned the FPN down for a similar request to continue helping with Braulio Carrillo land acquisition. OTS board member Thomas yuill wrote Ugalde saying that the current situation at Braulio Carrillo was just too "discouraging." He explained that there was too much private land within the zona Protectora and that the FPN was being "overly optimistic" with its land-swaps plan. He also mentioned that Peter Raven (of the OTS board) had met with "unrewarding" fundraising attempts on behalf of this cause. (Yuill to Ugalde, 12 october 1983, SPN file no. 1206.) 
acquisition in Braulio Carillo National Park." And in 1984, the WWF, the Norway Chapter of the WWF, and the New York Zoological Society contributed a total of $\$ 84,000$ for help with land pur119

chases at Tortuguero, to list but a few of the donors. "It was breaking new ground," as Ugalde described his campaign effort, "It was not a fad to donate money for conservation in those weird third world countries with unrest and corruption and whatever. Costa Rica, they [the donors] didn't even know where it was."

To educate the donors, then, the Costa Ricans' fundraising campaign became more sophisticated than it had been in the past. The plan now was to bring potential contributors to Costa Rica and show them first hand what the projects were all about. Such was the approach that Mario Boza took when he directed a grant proposal for the Tinker Foundation in mid-1983. The foundation's president, Renate Rennie, visited the country that summer and, in a memo to SPN and FPN staff, Boza listed specific assignments for each person (who was to pick her up at the airport, etc.), issued a complete schedule of activities for her stay, and directed them "to attend to her well." The grant proposal itself was for $\$ 149,050$ as "seed money" for the first three years of a national environmental education program (as per one of the FPN's priorities) which would become a permanent, self-supportive fund. Ugalde summed up the importance of these visits when he said, "I think we raised the funds because we could bring the donors here to show them what we were doing; because we had a good record of democracy; and because of our own dedication to the cause." 
Another benefit to the program came when Mario Boza and Alvaro Ugalde were awarded the Getty Prize (for conservation) in 1983. They accepted the award in washington at a Rose Garden ceremony presided over by U.S. President Ronald Reagan. "Creating a park on paper is easy," Boza stated in his acceptance speech, "preserving it is another story. We have to teach the people what conservation is.. . [that it] is a tool of development." Ugalde later lamented that there was a lack of press coverage of the event and that Secretary of Interior James Watt was not in attendance because of the troubles he was facing in those last few days of his in office. Other coverage of the FPN's campaign, and especially of the Costa Rican national parks themselves, did come in the form of articles in U.S. and British conservation magazines and journals which helped greatly to raise awareness of the cause. But in conclusion, and to make a long fundraising story short, the FPN's 5.5 million dollar drive succeeded by 1986--in less than the hoped for five year period. There is a human side to Costa Rica's quest to consolidate its park holdings. As Diputado Hubert Rojas had orated to his colleagues in the Legislative Assembly during the Palo Verde affair, people's land was often confiscated for park creation purposes. A representative case in point made it to the office of the presidency in the spring of 1982. Nelly Boza Guadamuz wrote directly to the president begging him to prevent the government from taking over her land in Alajuela province. Writing as a "campesina, worker of the land, mother of several 
children, and becoming elderly in age," the woman cited how she had heard that her "parcel of land" could "be taken away to make into a park, projected to be [named] Garobito."* Closing, she wrote emotionally, "I beg you to tell them not to take away what has cost me so much pain and tears." The letter was forwarded to the desk of Jose María Rodrlguez at SPN who later informed the President's office and Nelly Boza Guadamuz that the area had since been withdrawn from park feasibility study "for its lack 123 of appropriate national park characteristics."

Others who were forced to move for the improved conservation of the country were usually paid for their land (when money was available) and were assisted in their move to another location. The issue became more complicated in the mid-1980's, however, when a gold boom hit the Osa Peninsula in southwestern Costa Rica and prospect miners (oreros) flooded into Corcovado National Park. Mining operations in the park environs had been suspended when President Oduber decreed the park's creation and when Roger Morales spearheaded the orero relocation effort. But with the Costa Rican economy in shambles and high unemployment $(\mathrm{n}=79,000$ in March of 1982--a forty-four percent increase from that time one year earlier), many individuals sought work and wealth mining for gold. A study in 1985, however, estimated that ninety percent of the miners in Corcovado had other sources of employment

\footnotetext{
* The proposed Garobito National Park was named after a legendary regional indigenous leader who during the Spanish conquest of Central America had eluded conquistadors by his clever tactics and intimate knowledge of the environment.
} 
and that thirty to fifty percent owned farmland in the region. Permits to reroute the Rincón River for placer mining were denied by the Ministry of Industry, Energy, and Mines (MIRENEM) but that hardly slowed the influx of oreros who set up their own individual mining operations in and around the park. Another study showed that there were 1,500 illegal oreros in Corcovado and 3,500 "legal" mining concessions in areas surrounding it. The problem for the Park Service was that MIRENEM issued a report outlining how public lands could be used for mining (in accordance with Article 39 of the Mining Code). It also encouraged miners to continue their pursuits as long as they had a mining permit and followed certain norms. The report further indicated that the Central Bank in San Jose would continue to buy gold at international market prices ("representing its importance to the Costa Rican economy"). In October of 1982, for instance, Costa Rica had exported 568 kilos of refined gold at a value of $\$ 3,558,080$. Also, in 1983 a legislative committee met with members of industry and of the conservation community to discuss what sort of mining could be allowed. It was generally agreed that placer gold mining for small scale artisanry would be allowed and that water pumps and dynamite would be restricted to 125

certain areas. But when oreros continued to stream into the area, the few guards posted at corcovado could not come close to monitoring permits or seeing if Mining Code "norms" or regulations were being followed.

By 1985 Alvaro Ugalde had left washington, D.C., to resume 
his duties as director of SPN. Ugalde sensed very closely the growing crisis in Corcovado and wanted to do what he could to protect the park. He commissioned Dan Janzen, an oTs board member and University of Pennsylvania tropical ecologist famed for his specialty on the tropical dry forest ecology of Guanacaste, to conduct an on-site study of the orero impact on Corcovado. Janzen's research team found significant damage to the park ecosystem: mammal species were nearly eliminated, streams were sterile and muddy from sediment run off (Janzen learned that a common local saying was "if the river isn't muddy, you're not working hard enough"), organic life in rivers and streams was almost completely absent, and plant communities had been severly altered. The report concluded that "several centuries will pass" before 126 pre-mining ecological conditions could be restored.

Not surprisingly, then, Janzen's study called for the complete removal of oreros without compensation. His study cited a series of laws that had been violated by having miners in the park and recommended that SPN utilize the Rural Guard to assist in removal. On March 2, 1986 (nearing the end of Monge's term) the Rural Guard drove out the oreros, destroyed their makeshift shelters, and seized their mining equipment. * Alvaro Ugalde later told David Wallace that "The gold mining situation was another awakening for the Park Service, it was our biggest mis-

* Later in 1987, many of the evicted miners camped out for several weeks in San Jose's central park demanding compensation for the Rural Guard's destruction. The government ended up paying $\$ 3,800$ to each of the displaced miners. 
take." He related how it woke up the Service to realize that "if you think people are going to respect the parks just because 127

they're parks, forget it." Illegal mining activity resumed in Corcovado and its surroundings in the late $1980^{\prime} \mathrm{s}$ and early $90^{\prime} \mathrm{s}$.

One conservation lesson gleaned from the Corcovado orero experience was that the buffer zones surrounding national parks and reserves are as important to the ecological health of the environment to be protected as the park itself. With that in mind, Ugalde and Rodrigo Gámez, a plant virologist active in conservation issues, decided to form an organization dedicated to the protection of ecological buffer zones in 1986. Called Fundación Neotrópica, the foundation began similarly to Fundación de Parques Nacionales (they even shared the same office space for several years) but with a different focus for raising and channeling funds and, now, without the ties to the government. It is a private foundation that works to acquire land for conservation, and more recently, to promote programs in environmental education. It also has served as a "bank" for debt-swaps and other fundraising activities and is yet another example of Costa Rica's suc128 cesses in conservation through crisis.

There were also some successes on the legislative front. In the fall of 1982 the Legislative Assembly passed the National Ratification Law (no. 6794) that ASCONA had lobbied for during the Palo Verde situation. President Monge inked it into law at a ceremony on october 16. The speech he gave at that event, however, had been written almost entirely by Alvaro Ugalde upon the 
request of a Monge aid who had written him asking for ideas. The

President (or Ugalde) outlined in the speech a plethora of advantages acrued from conservation practices and ended by saying

Perhaps I will be the last President of Costa Rica who will be able to create new and indispensable natural conservation areas like national parks, biological reserves, and national forests. My successors will only be able to improve them or allow for their destruction. . . . Let's consolidate the system of national parks and let's establish others that the scientists recommend as ones of great importance to save. . . . I urge all Costa Ricans to join groups like Fundación de Parques Nacionales and ASCONA so that, together with the government of the Republic, we can achieve concrete actions in the field of rational use of natural resources and conservation of our biological diversity.

Other goals were achieved during the Monge administration.

In the fall of 1982 the government inaugurated the "Volvamos a la Tierra" (Return to the Earth) program to encourage "balance between man's actions and the ecological possibilities and limitations in which they develop." It was a program "with profound conservationist ingredients" designed to show how the basic necessities from the land (i.e. food, fibers, medicines, etc.) could be used "without reducing the natural environment on which we depend." (See Figure $\mathbf{2 .})$

At the same time OFIPLAN approved funding a program to research the needs of the country's forestry education. It's goal was to discern "what directions should be taken in forestry research" and to discuss the idea of creating one consolidated university level forestry program. And in october of 1983 José Maria Rodriguez noted in an SPN report that significant advances 
Figure 2: Poster for President Monge's "Back to the Land Campaign

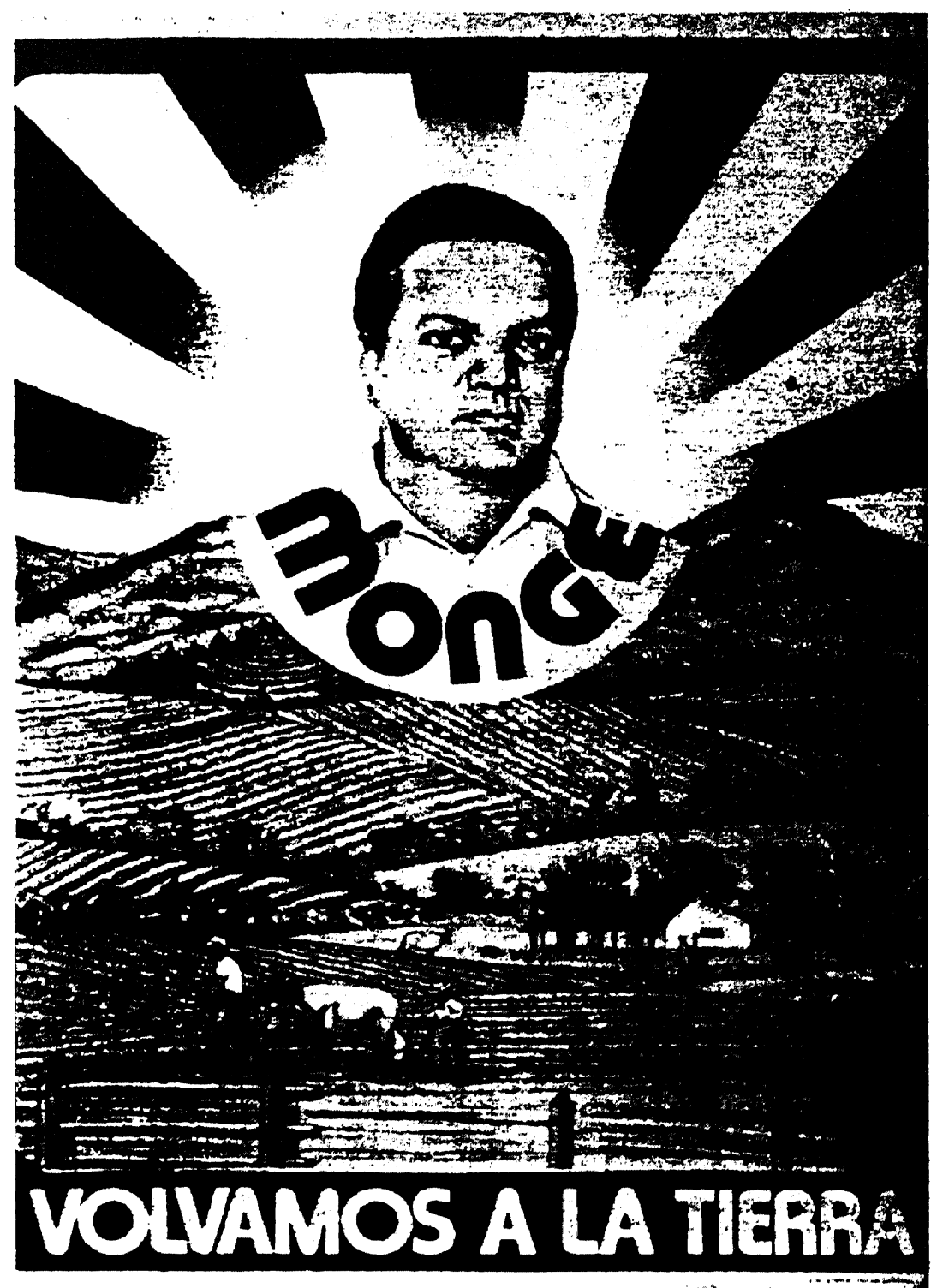

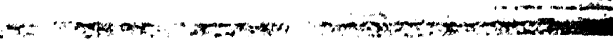

(source: Manuel Rojas, Los años ochenta y el futuro incierto [San Jose: Editorial UNED, 1991]

had been made in his department's environmental education program. Some of the achievements included nation-wide radio spots, school presentations, university conferences, short television announcements, pamphlets produced for each park, outdoor exhibits and booths at the parks, and a two week workshop on environmental education held at poás Volcano. "The results have been satisfac- 
tory," wrote Rodríguez, "despite the limitations of budget re130

sources and personnel that we have had."

The nation's financial limitations gave birth to a variety of plans that supposedly would boost the economy. However, many of these plans, like gold mining in Corcovado, presented grave dangers to the environment. Another such controversial environmental dilemma that the Monge administration had to confront was a proposed trans-isthmian oil pipeline (oleoducto) that would connect the Caribbean coast with the Pacific. Different plans for such a project had been in the works since the late $1970^{\prime} \mathrm{s}$. Neither plans for a pipeline near Golfo Dulce (scuttled by President Oduber) or one across northern Costa Rica (supported by President Carazo) had ever materialized, thus opening the possibility for a new proposal in 1982-83. Proponents, including the government, supported the plan as a boon to the economy. Environmentalists opposed it based on potential ecological impacts that could result from the oleoducto's construction and possible rupture and spills. The environmental group ASCONA presented especially strong opposition to the proposal.

ASCONA carried the banner against the pipeline. The group worked to publicize the environmental and economic effects of recent oil spills in Alaska and Panama. It cited how possible spills in Costa Rica would negatively affect the coastal fishing industry and the budding tourism industry. It showed how the pipeline's construction, and parallel maintenance roads, would augment deforestation, contaminate rivers, and forever 
damage wildlife habitat. Alexander Bonilla, who dedicated himself in those years to the fight against the pipeline, wrote that "we ecologists believe that construction will bring serious environmental consequences that would have repercussions on the national economy." He further explained that "this position is not romantic, unpatriotic, and much less of the extreme left as some sectors of the government have been suggesting."

Although no trans-isthmian oil pipeline was ever built, the oleoducto controversy caused ASCONA's eventual demise. Bonilla has asserted that "pro-government persons infiltrated" the organization at the height of the campaign and "tried to get ASCONA to adopt an official position in favor of the project" despite its own statutes and history of vigorously opposing such measures in the past. Those people did not succeed in altering ASCONA's position, Bonilla claimed, but through the infighting they generated and negative publicity they caused, ended up breaking the organization. And while the group still exists "on paper" today, Bonilla (who has since left ASCONA) explained in a recent interview, "it does not have any power; the oleoducto ruined it."

It was during this same time period that Bonilla was active on another environmental cause: the creation of the Partido Ecologista Costarricense (the Costa Rican Ecology Party, PEC). After years of studies and committees, the political party was formed in 1984 by a group of ambitious environmentalists and university scientists. Calling it a "new hope" for Costa Rica, Bonilla, who served as the party's first president, wrote that "the PEC 
was born as a new alternative among the traditional political parties whose environmental misinformation, ignorance of the ecological interrelationships of a society, and adherence to an ancestral economic hegemony have been transformed into the depredatory economic principles of the economic, social, and political structure of Costa Rica." 133

The PEC, which was modelled loosely on the concepts of the European "Greens," focuses on national environmental concerns, agrarian reform, and the principles of non-violence. It urges rigid adherence to Costa Rica's tradition of permanent unarmed neutrality. Bonilla has stated that the PEC goes beyond environmental activism, explaining in an interview with Bill Weinberg that "the problem with many ecology groups in Central America is that they fail to address the political and economic problems as part of the environmental problems." * But while the party has suffered from financial problems and, as another study put it, "not brought with it the fortification of the ecological movement" in Costa Rica, it has made a presence in many local and national elections. It is one of the few 134 "green parties" in Central America.

President Monge did not play a big role in the Corcovado orero situation or the oleoducto debate, but he was personally

\footnotetext{
* More recently Bonilla has disaffiliated himself with any environmental organizations and is a private, environmental consultant. He was the recipient of a U.N. "ecology in action" prize for his work on sustainable development. He continues to write books, provides environmental training workshops, and hosts a weekly radio program on ecological issues.
} 
involved in another environmental controversy: scandal number six at Santa Rosa National Park. The El Murciélago unit joining the park continued to be used for a military training grounds by the Civil Guard during the Monge administration and by 1983 became a staging base for the Nicaraguan contra faction of Edén Pastora. Financed by the U.S. Central Intelligence Agency during the Reagan administration, Pastora's forces attacked Sandinista soldiers at the border post (Peñas Blancas) just north of Santa Rosa and returned to El Murciélago. That and other border skirmishes caused damage and property loss on Costa Rican soil which prompted Monge's Minister of Public Security, Angel Edmundo Solano, to crack down on contra activity in Costa Rica and Monge to issue a Proclamation of Neutrality on November 17. *

Solano, who had gone public with his views that the CIA wanted to militarize Costa Rica's Civil Guard to join President Reagan's efforts against the Sandinistas, worked to enforce Monge's neutrality stance and met with Nicaraguan officials about reducing the border skirmishes. But right-wing groups in Costa Rica (i.e. the Chambers of Commerce and Industry, La Nación, and officials in the Ministry of the Interior) as well as U.S. Ambas-

* According to Andrew Reding ("Costa Rica: Democratic Model in Jeopardy," p. 309), Monge's proclamation was supported by eightythree percent of Costa Ricans, the Roman Catholic Church, and every country in the world, except the United States. U.S. Ambassador to Costa Rica Curtin Winsor, Jr., failed to attend Monge's proclamation ceremony. Bill Weinberg (War on the Land, p. 117) relates how winsor was eventually called home from Costa Rica "apparently for insufficient subtlety" after he mentioned in a public speech that Nicaragua was "an infested piece of meat that attracts insects from all over." 
sador Curtin Winsor, Jr., opposed Solano's interference with the CIA plans and pressed to have him removed.* Monge relented (in fact he shook up the entire cabinet) and named arch-conservative Benjamin Piza to Solano's position.

Piza was a founder of the MCRL (Free Costa Rica Movement, a John Birch-type paramilitary organization affiliated with the World Anti-Communist League) who immediately into his position accelerated the anti-Sandinista operations at El Murciélago. When Monge was gone on an official trip to Europe, Piza ignored the neutrality stance (and long range Park Service plans to conserve the area for annexation to Santa Rosa, for that matter) and worked with the CIA and the Pentagon to arrange the arrival of a U.S. Army Special Forces division (Green Berets). Along with West German and Israeli military advisors, the Green Berets conducted ten two-week sessions training 1,000 Civil Guards in jungle survival, counter-insurgency warfare, riot control, and border patrol operations in the fragile environment of the tropical dry forest of Santa Elena Peninsula.

The Guard units became known as Batallones Relámpagos (the Lightning Battalions) and supposedly were geared for anti-Sandinista warfare and for training other troops. Their staging ground in the forest was off limits to civilian Costa Ricans. Soon after

* In 1987, winsor admitted that working to have solano fired was part of his role in the Reagan administration's illegal Iran-contra operation. He suggested that silencing Solano would help stymie the investigation of Lt. Col. Oliver North's secret activities with the contras. (See Weinberg, p. 117.) 
the unit was discovered, former President Rodrigo Carazo advised that "these Lightning Battalions should be dissolved". . because a spirit of militarism is like a contagious disease."

But that was not all the peninsula adjoining Santa Rosa National Park was being used for. President Monge was reportedly furious upon his return from Europe to learn that Benjamin Piza had converted El Murciélago into a Green Beret training field. But, as was discovered when the story started to unravel after his term had expired, Monge had approved the construction of a secret contra resupply airstrip to be built on land that had been earmarked for national park expansion (scandal number seven). The 6,500-foot airstrip, part of the whole Oliver North "contragate" drugs-for-arms disgrace, was built in an ecologically sensitive part of Guanacaste where wildlife seasonally migrate between the pacific dry forest and the cooler highlands of the volcanic slopes. The peninsula is home to rare species of vegetation that have evolved over time due to the fact that the ground there has been above the ocean longer than elsewhere in 136

Central America.

President Monge claimed he sanctioned construction of the airstrip because officials from washington had warned him of an imminent Sandinista invasion of Costa Rica. The landing field, he believed, would be used to airlift in border defense supplies. Lewis Tambs, who had replaced Curtin Winsor as U.S. Ambassador to Costa Rica, pressured Monge to approve the plan by threatening to cut off U.S. aid--an unattractive scenario during the economic 
crisis.* Then, representatives from a Panama-based "dummy corpoporation" called Udall Research (engineered by Richard Secord and Albert Hakim of the "Project Democracy"), arrived in the town of Liberia, Guanacaste, to solicit cooperation from the local Civil Guard commander. They informed him that they were preparing to build a tourist project on the Santa Elena Peninsula and needed his support to transport workers, construction materials, and heavy equipment through Santa Rosa National Park. Advised by

\section{Figure 3: Political Cartoon Regarding Secret Airstrip near Santa Rosa National Park}

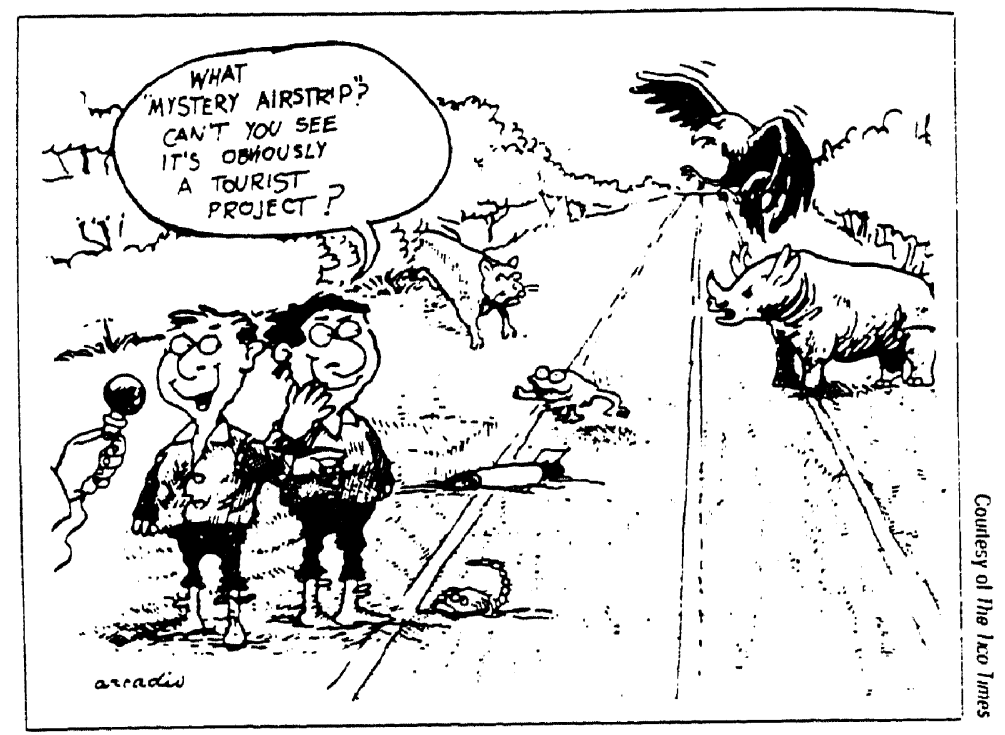

(source: Joshua Karliner, "Contragate: The Environmental Connection," EPOCA Update [summer 1987], 4-5)

* In the Tower Commission that the U.S. Senate used to investigate the "contragate" scandal, Tambs admitted that he and oliver North had also attempted to bribe Monge's successor, Oscar Arias, to cut off aid if he went public with the airstrip's discovery. Arias refused to be intimidated and held a press conference to announce not only the strip's existence, but also its closure. U.S. aid, however, did decline; it dropped from $\$ 180$ million in 1986 when Arias came into office to $\$ 85$ million by 1987 . (Weinberg, war on the Land, p. 119-120.) 
Public Security Minister Benjamin Piza to cooperate, the commander then pressured park officials for such a request and lent Guardsmen to assist with the airstrip's construction. The U.S. construction crew and Costa Rican Guardsmen, however, hardly respected the environment. They set forest fires in the area, hunted deer without permission, dined on rare Kemp's ridley sea turtle eggs, and at least on one occasion shot a tapir for sport. The affair finally came to light when local residents became suspicious in the fall of 1986. After repeatedly seeing large military transport aircraft flying low and landing (especially at odd hours) and military trucks moving fuel drums and other equipment in and out of the area, they alerted officials who discovered the secret strip.* By early 1987, the new President--Oscar Arias--had declared his intent to work with the SPN to develop the area into Guanacaste National Park. Such a plan was to be the start of a whole new administrative restructuring program that would characterize the future of Costa Rica's conservation agenda .

For their part, the individuals who had been so instrumental with conservation programs during the last two administrations

* Via the hearings from the U.S. Senate's Tower Commission and an investigative committee of Costa Rica's Legislative Assembly, facts surfaced regarding how the strip was used not only as a base from which to fly U.S. arms for the contras into Nicaragua, but also allegedly to fund Manuel Noriega's drug smuggling operation with funds from an arms-sale to Iran. The Legislative Assembly barred Oliver North, John Poindexter, Richard Secord, Lewis Tambs, and CIA Costa Rica Station chief Joe Fernandez from ever returning to Costa Rica. It also indicted Benjamin Piza and the Liberia commander who were a part of the team. 
would continue to be involved, if not in different capacities inside or out of the government. Alvaro Ugalde, for example, who in 1985 had returned to his position as SPN director to work on the Corcovado crisis, left again in 1986 at the end of Monge's term, "burnt out" from the work and emotional toil involved with the orero evictions. For the next four years he worked in a variety of non-governmental conservation positions, including ones at the Conservation Foundation and The Nature Conservancy, as an advisor to conservation programs in Paraguay and Guatemala, and even as a national parks guide for a major ecotourism firm in Costa Rica. Vera Varela succeded Ugalde as Executive Director of Fundación de Parques Nacionales. She later served in the same capacity at Fundación Neotrópica. Jose María Rodrlguez decided to take a leave of absence for his own training and professional development in 1984. Following in Ugalde's footsteps, he left the SPN for graduate work at the University of Michigan. Luis Méndez, a biologist who had been serving as SPN Assistant Director since the late $1970^{\prime} \mathrm{s}$, assumed acting directorship duties for 1984, moved over when Ugalde came back in 1985, but then was named SPN Director by the new Arias administration in 1986. Mario Boza remained active with the environmental studies progam at the State Open University and as president of the FPN.

The people and organizations like the ones mentioned here and throughout this chapter played an indispensable role in seeing Costa Rica meet the challenging goals of conservation through crisis. The experience gained from the 1978-1986 fundraising 
efforts was not shelved in the coming years. New opportunities and ideas for the $1990^{\prime}$ 's and beyond would mean drawing on past lessons and successes to continue and expand on the way the country's environment could be protected. 


\section{CHAPTER 7}

\section{RESTRUCTURING AND DECENTRALIZING CONSERVATION}

We Costa Ricans have achieved important successes in the preservation of our natural patrimony. In just a few short years we have been able to consolidate a system of protected areas . . . that perpetually guarantees the majority of our natural treasures. But we should recognize that until now the concept of sustainable development has not formed part. . . of the ways implemented for socioeconomic development.

- Oscar Arias Sánchez (1)

When Oscar Arias was elected President of Costa Rica in 1986 the national parks program of his country was in the beginning stages of undergoing a philosophical change in strategy. What conservationists and politicians now saw as the coming role of national parks and preserves was their ability to be incorporated into the nation's larger socio-economic context. Tropical ecologist Daniel Janzen, active for so many years in ecological research in Guanacaste but now moving into a conservation advocacy role, perhaps best explained the new phenomenon when he wrote, "The traditions of tropical conservation in general, and certainly in Costa Rica specifically, have to evolve with urgent haste to a mode where the integration of the park into the social consciousness is dominant and central to the entire [management] plan." The ideas of Arias and Janzen here, then, reflect the growing attention to "sustainable development" that started to flourish in international conservationist thought by the mid$1980^{\prime} \mathrm{s}$ and would set the tone for environmental policymaking in the next three administrations: Oscar Arias Sánchez (1986- 
1990), Rafael Angel Calderón Fournier (1990-1994), and José María Figueres Olsen (1994-1998).

One of the first testing grounds where the principles of sustainable development would be incorportated into the management plan of a protected area was with the creation of Guanacaste National Park in the late $1980^{\prime} \mathrm{s}$. When President Arias was handed the Green Beret and "contragate" airstrip scandals at Santa Rosa from out-going President Luis Alberto Monge, he was confronted with decisions that had to be made for the long-range use of the Santa Elena Peninsula and surrounding areas of tropical dry forest. To the east of Santa Rosa (and east of the Pan American Highway) plans had been in the offing since 1985 to develop a vast area of dry forest and sloping volcanoes into a large conservation area based on "tropical restoration."

The plan was the brainchild of entomologist and tropical ecologist Daniel Janzen who had been working, researching, and living in Guanacaste for over twenty years. He usually spent half of the year in Costa Rica and the other half back at his post in the biology department at the University of Pennsylvania. His research focus had centered on the life history of saturniid moths and on co-evolution (plant-animal-insect adaptations and interdependencies). But after an invitation by the government of Australia to study that country's dry forests (which were rapidly becoming extinct) and after his experience in Corcovado that Alvaro Ugalde had requested he do for the National Park Service (which alerted him to how endangered an ecosystem 
can become)--both experiences that took place in 1985, Janzen became converted to the gospel of conservation. Before that "I never gave a second thought to conservation," he mentioned to one reporter. To another he admitted that he "used to chain saw big trees just to count rings for my research with no more thought than you'd flick an insect off your sleeve." It was then that he witnessed with greater concern how the Pacific dry forest that once had spanned much of the west coast of Mexico and Central America was at the brink of ecosystem extinction. (See map, Figure 1.) Wasting no time, Janzen authored a study in 1986 study in 1986 entitled Guanacaste National Park: Tropical, Ecological, and Cultural Restoration as a format to present to the

\section{Figure 1: Original Extent of Pacific Tropical Dry Forest}

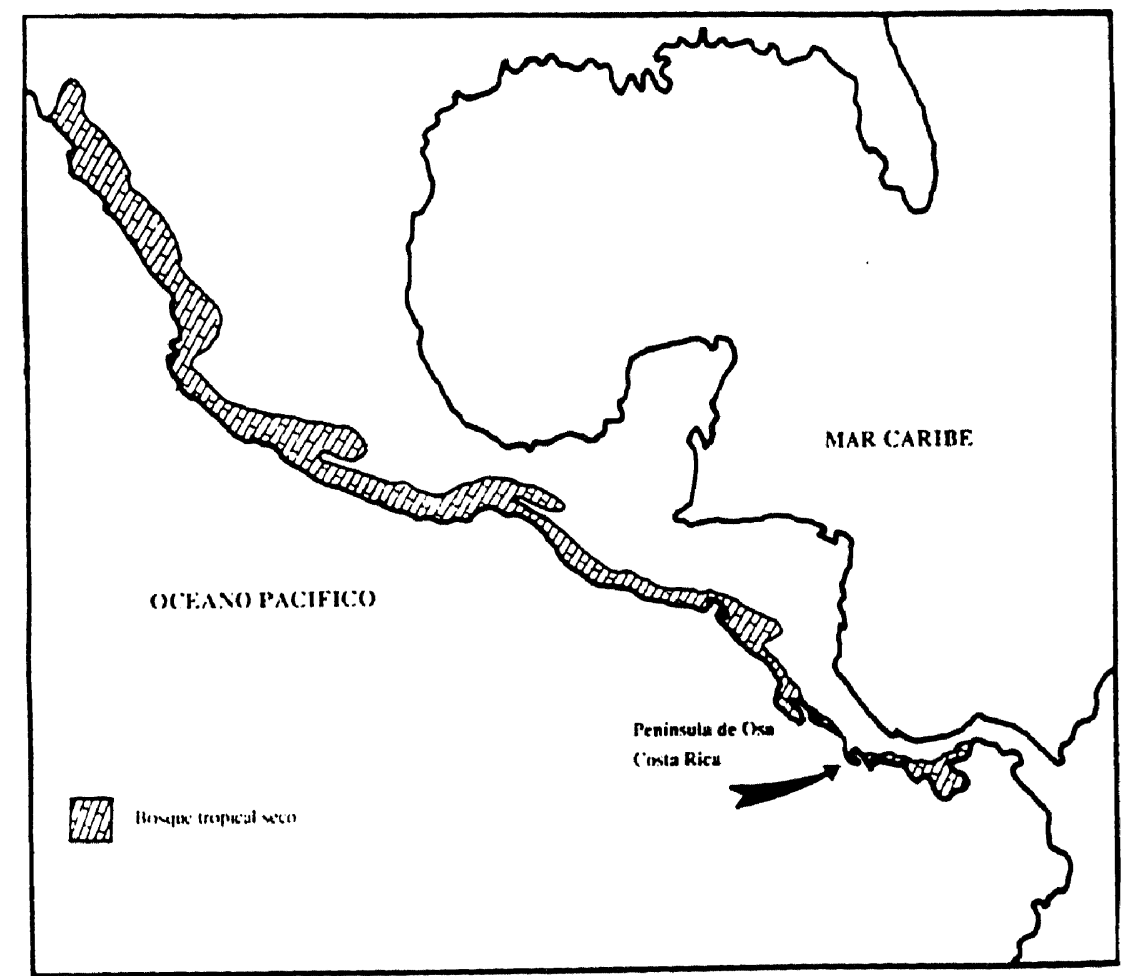

(source: Carlos E. Valerio, La diversidad biológica de Costa Rica [San José: Heliconia, 1991]) 
Costa Rican government in hopes the area would be considered for conservation status. Janzen noted in the work that only two percent (or 6,600 square miles) of the original 330,000 square miles of Mesoamerican Pacific dry forest yet remained relatively undisturbed and that only .08 percent (or 264 square miles) existed in legally protected areas (Santa Rosa National Park and several small reserves in Costa Rica and other countries).

The ecosystem disappearance, of course, was due to intensive burning and agricultural development. Since the days of the Spanish encounter, the tropical dry forest of Costa Rica had been used more than the country's rain forests for farming due to its vast savanna clearings and long dry season (November to April). It is a windy, leafless, and brown environment during that time and lush green and wet from May to october. The area has been cleared with annual fires for four hundred years which kept saplings down and moved the grasslands further into the forest mar5 gins. Answering his own hypothetical question concerning what would happen if the Guanacaste National Park Project (GNPP) area were not preserved, Janzen wrote:

We retreat to Santa Rosa (the Muricielago area will be roasted off the map by the wildfires) and carry out all of the goals for Guanacaste National Park on an inferior scale and in a gradually decomposing habitat. All of the inventory and other biological studies for Guanacaste will be priceless as salvage biology, and at least tell future generations what they lost.

Thus his goal was to "put biology back into [the local people's] cultural repertoir-back on the same status with music, art, and 
religion" as opposed to their current preoccupation with rice, cotton, sorghum, and cattle. And looking at the larger picture of Guanacaste's importance for Costa Rica and for the study of ecology in general, Janzen asserted that "to lose the abundance of tropical dry forest to the damands of agriculture is comparable to processing the books in the Library of Congress to relieve a temporary paper shortage."

What made the park specifically different from others was that its management plan retained some local economic uses. Cattle grazing, for instance, was allowed (although managed to prevent pasture depletion) which Janzen saw as beneficial for seed dispersal, grass control, and generating local support. Burning and hunting, however, were banned and reforestation projects launched as preliminary methods to restore the ecosystem. The plan was to plant just a few trees in the pastures that once had been forests and to let nature take care of the rest. Janzen's research found that the wind and the manuring effect of seed-dispersing animals (i.e. deer, monkeys, peccaries, agoutis, cotton rats, bats, and magpie jays which eat fruits and nuts then defecate seeds elsewhere) could work to start the restoration process in roughly ten years time. Restoring the entire area with "all the plants and animals that were here when the Spaniards arrived," however, will take hundreds of years.

\footnotetext{
* Janzen notes that there are twenty to forty percent fewer plant and bird species in the tropical dry forest than in Costa Rica's rainforests. The number of mammal, reptile, amphibian, and insect species is about the same. (In Constance Holden, "Regrowing a Dry Tropical Forest," 809.)
} 
Janzen's strategy for restoring and protecting this ecosysstem in Guanacaste called for manipulated management using both the natural and human resources of the area. Believed to be the first place in the tropical world to test such a theory, the goal was "to integrate the park itself into.. local and national society." The park was to be geographically large enough "to maintain healthy populations of all animals, plants, and habitats that are known to have originally occupied the site" and which would work for "habitat replication." The park would also serve as a "gene and seed bank," provide "watershed protection," and be available to limited numbers of both ecotourists and "convention9 nal" tourists.

This kind of a management scheme breaks from the past experience of Costa Rican national parks, which according to Janzen were modeled after their counterparts in the United States espousing a "caretaker" philosophy. The "parks basically have been taken care of by a police force," he argued in a 1988 interview, "they have not been managed with regard to their biological needs." $\star$ Nor, as he continued, have they succeeded in adequately 10 including local residents into their overall operation. At Guanacaste National Park, Janzen set up programs for local school children such as field trips to the beaches for biology lessons. Some of the children even helped pick seeds out of horse dung to be planted later where needed. He also employed area work-

* This thinking has not always endeared him to Park Service employees. Resentment finally led to the government's request that he leave Costa Rica for awhile. (Tom Barry, Costa Rica, 75.) 
ers to help collect and catalogue specimens from the park's plant and animal life and to be on fire control teams ("broom squads") during the dry season. "The fire crew is deadly," he told a reporter in 1989, "only six percent of the GNPP burned this year, as compared with the traditional thirty percent barbecue." Some local farm families elected to stay on their farms but work for the park--adding to the complete "selfsupporting . . biocultural restoration" of the environment. "We have to integrate the park into the minds and pocketbooks 12 of the community," he added.

The pocketbook of the government at the time Arias took office, however, could not sustain purchasing the amount of land called for in Janzen's proposal. Janzen had approached Arias about the park idea and received his blessing for it, but was informed that the government could not support it financially at that particular time. Undaunted and satisfied to have Arias' support for the project, Janzen launched his own fundraising blitz. Mario Boza at Fundación de Parques Nacionales (FNP) gladly endorsed the idea and enlisted the support of his organization. Alvaro Ugalde (soon before his departure from the National Park Service) was less enthusiastic at first--based on the number of other pressing needs at SPN--but warmed to the idea later after an on-site hike with Janzen. Fundación Neotrópica, the organization that Ugalde helped found, also joined the effort. With his "engaging personality and eccentricities," as one reporter described him, (he was known to wear a snake bag with specimens on 
his head, share his specimen-cluttered home/laboratory in Guanacaste with skunks, and utilize a rich and colorful vocabulary), Janzen became the darling of international conservation organiza13

tions. He was the subject of a BBC television documentary and many journal and magazine articles. Shying from the publicity, however, he mentioned in an interview with David Wallace his distaste for the media "to lionize individuals:"

A particular need or challenge occurs. Somebody puts his hand up first and says, 'Okay, I'll do that job.' So he does it, and we look at the job and say 'That was important.' But if he hadn't done it, somebody else would have." (14)

Nonetheless, his efforts garnered major contributions from the Nature Conservancy, the World Wildlife Fund, and other groups amounting to three million dollars by 1987 (one fourth of his estimate that was needed to purchase the land in the area)--only one year into his fundraising drive.* In that time he had convinced fifteen farmers and landholders in the area to sell (the land within the park boundaries was not of great agricultural quality anyway). He also had received the promises of other property owners to resist selling until the next year when he

* Thomas Lewis, who interviewed Janzen regarding the fundraising in 1989 wondered "whether he, who owned neither a home nor a business suit, was the man to raise $\$ 12$ million? Whether he, with the scholar's usual distaste for politics, could achieve the delicacy of maneuver such an undertaking required? Whether a man who had spent much of his life probing the secrets of animal excrement, for clues to the distribution of seeds, was prepared for truly distasteful tasks such as asking for money and dealing with journalists? 'You see something that needs doing,' he shrugs, 'and you do it.' [Thus] Janzen undertook a metamorphosis worthy of one of his beloved moths: from reclusive biologist to garrulous after-dinner speaker." ("Daniel Janzen's Dry Idea," 36.) 
15

would have more funds. By the end of the decade the park was complete.

Janzen got a great deal of assistance in those years from the conservation foundations, environmental groups, and the government of Costa Rica. One of the biggest boosts came with the innovative introduction of "debt-for-nature" swaps in the late 1980's. An idea conceived by Thomas Lovejoy at the World Wildlife Fund (WWF) in 1984, debt swaps were intended to help developing countries reduce their foreign debt while at the same time increase their budgets for conservation. The plan involved foreign banks selling off their loans they had made to deeply indebted nations to international conservation organizations. For Costa Rica, the loan notes went for seventeen cents on the dollar which were then donated to Fundacion Neotropica. The government's Central Bank then issued bonds to Neotropica for seventyfive cents on the dollar (using colones), which multiplied the value of the discounted loans and allowed Neotropica to use them as collateral which drew twenty-five percent interest. Meanwhile, the U.S. Internal Revenue Service sweetened the incentives for banks by ruling that they could write off the swaps as partial charity contributions. The Fleet Bank of Rhode Island, for example, retired a portion of Costa Rica's debt to the bank by 16 donating $\$ 250,000$ for land acquisition and park management. With this kind of program in gear, then, the Arias administration formed the Costa Rica Debt Conservation Plan in 1987. 
Its goal was to "enable the government to pay off part of its debt and simultaneously invest in long term environmental projects." By 1991 over forty million dollars of external debt had been erased by purchases from international organizations.* Costa Rica was the third country in the world to participate in the swap program and the first to receive European support when 17 the Netherlands and Sweden forgave their government loans. Sweden's contribution was specifically earmarked for restoration of the Pacific dry forest in Guanacaste. The Nature Conservancy worked as an intermediary with Sweden and the United States on these swaps and parlayed 5.6 million dollars of Costa Rican debt

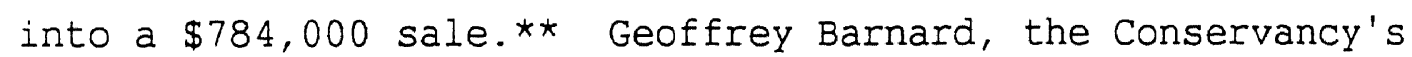
director for Latin America (and the group's former Costa Rica field representative), stated at the time that Costa Rica was chosen over Panama and Nicaragua--countries with equal if not greater conservation needs--because of the security of the in-

* While debt-for-nature swaps have been beneficial for Costa Rica's conservation program, some studies have warned of possible abuses. Michael Redclift and David Goodman (Environment and Development in Latin America, pp. 15-16), list ten potential pitfalls inherent in the debt reduction plans, not the least of which are their inattention to management of protected places, and questions of national sovereignty and local control of resources. Bill Weinberg (War on the Land, p. 114) agrees and cautions against the swaps to be used by governments "to allocate resources according to a foreign agenda."

** A supporter of debt swaps, environmental activist Alexander Bonilla said in an interview with Bill Weinberg (War on the Land, p. 114) that the approach allowed the "wealthy nations of the North to take their share of the responsibility for tropical forest restoration" and was a way "to avoid both the twin global disasters of economic collapse brought about by massive debt default and ecological collapse brought about by rampant deforestation." 
vestment with Costa Rica's stable government.

Fundación Neotrópica's end of the business was handled by Mario Boza who had become its director during the Arias administration. "Debt swapping is the most important tool to achieve conservation," he stated in a 1988 interview,

You multiply money by five. It's a lot of money that's free. We can use it to buy land, pay personnel, and do everything. It's an incredible scheme.

He went on to relate how the funds were to be used not only at Guanacaste National Park but at other areas as well. They were needed to improve the parks to attract more tourists and scientific research projects. "Then we can ask the government for more money," Boza continued,

That's the way to sell parks. You can argue that conservation is important for our heritage and good for our children and grandchildren. But if you do, you're lost. No one is interested in future generations. People want their reward now. (19)

The Fundación's main goal was to enlarge the existing parks from ten to fifteen percent of the nation's territory by the year 2000. Neotrópica also managed certain sections of land to be protected until the government had the proper financial resources. Alvaro Umaña, Arias' Minister of Natural Resources, clarified some of the goals by stating that his ministry wanted "to buy the inholdings in parks, improve the management of the parks, and develop management plans for buffer zones with integrated rural development." 
Buffer zone integration into the park system was a relatively new conservation ideal. At the same time efforts were mounting in the United States to protect areas around national parks (i.e. the Greater Yellowstone Ecosystem movement in the early 1980 's), similar attempts were underway in Costa Rica. University of Costa Rica biologist Sergio Salas had argued for "park ecosystem" protection--as opposed to protection for fenced off areas only--in 1981 at the First Symposium on National Parks. Daniel Janzen, another outspoken proponent for the concept that he referred to as "edge biology," advised that protecting up to approximately three miles depth surrounding parks was essential to the natural integrity of the parks themselves. Without managing the buffer zone of Santa Rosa effectively, for example, Janzen warned that a scheduled oak reforestation plan there would have "as much chance to influence the overall climate of the park [to improve environmental conditions] as [would] an ice cube." Thus the overall plan for Guanacaste National Park was for it to combine with Santa Rosa to form an ecosystem "mega-park" of tropical dry forest.* This was the beginning of SPN's new focus on restructuring conservation to fit biological realities. Janzen explained that Costa Rica's national park system should not be "viewed as a series of islands, but rather as a network partly

* Simultaneous to the "mega-park" plans was a concerted effort to establish more small forest reserves. Ever since Luis Fournier and Maria E. Herrera de Fournier published an important article on the subject in 1979 ("Importancia cientifica, económica y cultural de un sistema de pequeñas reservas naturales en Costa Rica," Agronomía Costarricense 3:1 [1979], pp. 53-55) there had 
connected by migrants." To achieve this goal in Guanacaste meant acquiring lands to the west of the Pan American Highway also--the land on the Santa Elena Peninsula that had been used for military training during the Monge administration. In 1987, President Arias announced that the "Udall Research" land where the clandestine airstrip had been constructed would be annexed into adjacent Santa Rosa National Park. It required financial negotiations--what Janzen termed "bureaucratic chug-along"--with the North American investors from whom "Udall" (read: the CIA, etc.) rented the land. The deal was completed one year after the scandal was uncovered. On the other hand, Arias decided against incorporating the El Murciélago hacienda into the park. It remained a Civil Guard training facility although minus the 22

Green Berets.

But the Relámpago Battalion controversy near Santa Rosa was not the end to the U.S. Army Special Forces' experience in Costa Rican national parks. In the summer of 1989 the Green Berets were in a remote part of Braulio Carrillo National Park at the

been a growing interest in local small reserves. The Fourniers wrote that small reserves (especially in the Central Plateau) would represent "true relics of great importance for future comparative studies with disturbed areas" and that they would be a "complement to the National Park System." Mario Boza (in Marjorie Sun, "Costa Rica's Campaign," p. 1369) tended to agree but thought that they would be "heavily used for recreation, but they won't be important for ecology." And on the far other side of the spectrum was Daniel Janzen (in Thomas Lewis, "Dry Idea," p. 34) who called small reserves "biological Rembrandts" which give the illusion of forest preservation but in reality do not provide room for all the diverse natural fragments (i.e. soil types, rainfall, drainage patterns, elevations, wind exposures, slope gradients) which combine to make small but vital contributions to the complex ecology of the area. 
request of President Arias' Minister of Public Security to train

Civil Guards in anti-narcotrafficking tactics. The park recently had been consolidated when ex-President Monge, as one of his last acts in office, approved the annexation of the Zona Protectora that Rodrigo Carazo had decreed years earlier. Likewise, in February of 1988, UNESCO had declared a central portion of the park as a World Biosphere Reserve.* Thus, when news of the Berets' presence there reached the press, conservationists were stunned.

The surreptitious military training was discovered in August 1989 when a Costa Rican naturalist with two American ecotourists stumbled onto the training session while hiking in the cloud forest. After the soldiers escorted the trio from the area, one of the members of the party told a reporter for Mesoamerrica that "We didn't understand why Americans in camouflage uniforms were throwing us out of a national park in Costa Rica. We thought it was outrageous." The park director at Braulio Carrillo was equally appalled and told reporters that the Green Berets and the Civil Guards had no permission to enter the park as per Forestry Law clauses that prohibit military manoeuvres in protected areas.

* Not all conservationists were eager to embrace the "biosphere" concept--in Braulio Carrillo or anywhere else. Daniel Janzen ("The Evolutionary Biology of National Parks," p. 110) warned that "by giving these parks [a] new name... as they evolve, the administration runs the risk of abandoning a significant part of the substantial body of social approval already accumulated in the public and governmental mind for any entity called a national park. . . . We simply cannot afford to have two species of wildlands conserved for their biodiversity--one being static national parks and the other socially dynamic biosphere reserves." 
But while the Green Berets went home, and an embarrassed Arias administration dealt with damage repair (it was only two years earlier that Oscar Arias had received the Nobel Peace Prize for his efforts to halt the wars in Central America), the U.S. Army was also conducting activity with environmentally dangerous implications in southern Costa Rica. In 1989 the Army Corps of Engineers began building and improving roads on the Osa Peninsula as part of its "Roads for Peace" mission. The plan was actually part of the Reagan administration's paranoia about communist infiltration in Central America--believing improved roads in the region could assist U.S. military efforts in the event its presence was needed to counter some aggressive force. One study concluded that the roads were being built as a preparation for a U.S. armed invasion of Nicaragua. In addition to the unrealistic philosophy behind these scenarios, the project alarmed Costa Rican environmentalists because the roads that the Corps was constructing led directly into Corcovado National Park. With the gold mining situation still not firmly resolved, the concern was that the road would be a conduit for oreros to bring 24

futher ecological destruction to the park.

The conservationists had reason to worry. Despite the efforts of the SPN to rid Corcovado of mining activity during the Oduber and Monge administrations, in 1987 the government hosted the International Gold Conference in San José as a means to lure investment to the Osa Peninsula. A joint University of Costa Rica/U.S. Geological Survey study recently had confirmed the 
presence of large deposits of gold on the Osa, a fact that was highlighted at the conference. The Tico Times reported on 23 October 1987 that Arias' Minister of Natural Resources Alvaro Umaña told the conferees that "There exist areas in which you can't mine--like our national parks, for instance. If we're going to develop the industry, we must also protect the environment. However, the majority of the area is certainly open to exploitation."

The problem was that if the area was open to mining it was easy for an orero to cross over into Corcovado. In 1988, for example, eighty some miners were arrested in the national park. And according to the Tico Times, fifty more were caught inside park limits in September 1989, including two who had held park 26

guards hostage overnight. Actually the problem illustrated very clearly the need for what Daniel Janzen and others were calling for: park management guidelines that included socio-economic criteria. The problem was bigger than campesinos wanting to strike it rich; it reflected an absence of agrarian reform. Alexander Bonilla addressed this very concern when he stated in an interview with Bill weinberg that he would endorse a Corcovado plan that included

a limited group of oreros exploiting gold in the park for artisan purposes using traditional techniques. Indigenous and traditional people must be incorporated into national parks systems. The large-scale corporate gold exploitation can only be allowed in the context of a rational plan for sustainable development, a strategy which will protect natural resources and contribute to the development of the region and Costa Rica. (27) 
In a more recent interview, Bonilla explained that "a clear vision" of sustainable development was needed--one that recognized that "humans are animals first; that they are a part of Nature" and therefore should hardly be excluded from park use plans. "We need to find the point of equilibrium," he advised, "without it there will always be socio-economic problems. . . Conservation with hunger is impossible."

Although Corcovado's management plan did not include smallscale gold panning (even avid "socioeconomic use" advocate Daniel Janzen had recommended total removal of miners in his Corcovado report to Alvaro Ugalde back in 1985), the National Park Service did start to consider locally-based economic park uses during the Arias administration. The problem, as former Arias natural resources advisor Rodrigo Gámez remembered, was that We'd never heard of the phrase 'sustainable development' then. It didn't exist in 1985. But I'm a generalist. I know the practical problems of food production in marginal areas, which is where most of the parks are. It's not possible for a population to have a sufficient level of development, a satisfaction of basic needs, working under such poor conditions. I could see that if we didn't pay attention to that, we'd be like Africa in a few years, with impoverished people pressing on the parks from all sides.

Thus one of the new tactics that the SPN worked on was a "mixed management" program to integrate people who lived within or near the borders of protected areas into the park planning itself. For some residents it meant being trained as tourist guides or to help with agroforestry projects. Eric Ulloa, assistant to the Minister of the Natural Resources in the Calderón administration, 
stated that this plan was part of the "new criteria. . . to create protected areas where the people living there will not be expelled." He explained that the idea was to help them to develop an economic base using the local natural resources. The ministry where Ulloa served, Ministry of Natural Resourcs, Energy, and Mines (MIRENEM), was a new branch of the government conceived during the Arias administration. The President created the agency (approved by the Legislative Assembly) to restructure and unify the management of Costa Rica's public lands and to deal with other conservation issues outside of agriculture. The plan moved the Park Service and the Forestry Directorate (DGF) out of the Ministry of Agriculture and Livestock (MAG)--a move roundly applauded by conservationists and something that Mario Boza had been urging for years. Also falling under MIRENEM's umbrella were the Department of Wildiife, the Department of Geology and Mines, and the National Zoo. During the Calderón administration MIRENEM relocated to the vacant ten-story Hotel Talamanca near downtown San José and SPN moved its offices into an adjoining house--moves that saved millions of dollars and conserved natural resources had a new facility been built. MIRENEM's name was changed to Ministry of the Environment

* The program has been slow to succeed in Cahuita National Park on the Caribbean coast. Kurt Kutay ("Cahuita National Park: A Case Study in Living Cultures and National Park Management," 118119), an outside researcher, found that in 1990 the local AfroCaribbean population had not had much input on park uses and that their basic needs had not been met ever since the park had been established. He concluded that "a working relationship between park authorities and local people ha[d] completely broken down." 
and Energy (MINAE) as part of the government's on-going restructuring process when Jose Maria Figueres was elected in 1994 . Its offices have remained at the MIRENEM building.

Arias appointed Alvaro Umaña to head the newly created ministry. A stanford-educated economist and environmental engineer, Umaña took a very hands-on administrative role with the departments in his agency. He kept Luis Méndez as SPN director for the first few years of the term but replaced him with Alfonso Matamoros, a DGF official, in 1989 when the Service was starting to slide. Alvaro Ugalde, who came back to SPN in the Calderón administration, explained that in the Arias years "the power rested in the minister (Umaña) and his advisors. . [ [p]olicy was made without consulting the Park Service." The way Ugalde saw it,

There was no internal leadership. . . . The power within the Park Service all split into little groups here and there. There was no institutional concensus of what to do, where to go. What with the government being broke, Luis Mendez didn't have the political leverage to keep the budgets up or get government support, so it was an economic debacle, losing positions, losing all kinds of support. It was very bad to watch the internal fighting. It was kind of a lost institution. . . [Umaña] was never able to work as a team with anyone here. (32)

Budgets continued to be too small for needed services, the SPN could not afford to hire additional park guards, and employee dissatisfaction was on the rise. Park Service personnel went on strike in April 1990--shutting down the offices and the parks for a few days in the process.

Administrative constraints aside, Umaña carried the ball for the process of restructuring the administration of protected 
areas, especially given the new emphasis placed on "mega-park" connectedness. Working with other MIRENEM officials he developed a system of regional conservation units (Unidades Regionales de Conservación, or URCs) to incorporate the parks and reserves within a geographic area into a new administrative district. The Lower Tempisque URC, for example, included Palo Verde and Barra Honda national parks, the Lomas Barbudal Biological Reserve, and Rafael Lucas Rodríguez National Wildlife Refuge. Guanacaste and Rincón de la Vieja national parks fell into the Guanacaste URC. La Amistad and Chirripó national parks and Hitoy-Cerere Biological Reserve became the La Amistad URC. The URCs included all of the parks, biological reserves, forest reserves, wildlife refuges and indigenous reserves within that district. The plan called for a "management strategy" for each URC that included community input from people who lived in or around the protected areas and from park personnel there, as opposed to management decisions coming only from San Jose. It was the birth of decentralized 33

park administraton.

The URCs were also an experiment in alternative financial management. NGO's, especially the Fundación de Parques Nacionales, controlled the park finances using a core committee of SPN and FPN officials as well as local business and community leaders. Juan Carlos Crespo, FPN president in the late 1980's when Mario Boza became its director (he was also director of Fundacion Neotropica), called the system "visionary planning" to protect 34 and manage the parks and the area of influence around them. 
Umana was also a foot soldier for incorporating the theory of sustainable development into the policymaking duties of his agency. More than just a verbal proponent of the ideal, Umana was active in promoting what he called an "aggressive" and "ambitious" reforestation program in parts of the denuded countryside as a way to prevent erosion, restore farmland, and protect hydrologic resources. In a press release in the fall of 1987 he made known that in the administration's first year alone (1986) almost 15,000 acres had been reforested which was double the acreage of 1986 and more than in all the years since 1969 . He also oversaw a MIRENEM study that created and implemented the National Conservation Strategy for Sustained Development. The strategy was the offshoot of Costa Rica's participation at the 1980 world Strategy for Conservation (jointly sponsored by the U.N. Programme for the Environment, the IUCN, and the world Wildlife Fund) but was not fully completed until the late 1980's. The strategy's objective was to "change the thrust of development toward a more sustainable form" and inhered an evolving effort to keep up with advances in technology and discoveries. It was also created as a mechanism to respond to the "inadequate and unenforceable legislation, poor organization, inadequate environmental planning, and lack of conservation36 based rural development" of the past.

Nine principal objectives and fourteen sectors of focus were identified in the Strategy (see Appendex 5). The objectives were national environmental goals that would work for balance between 
development and conservation. The sectors were specific areas of focus (i.e. watersheds, mining, etc.) that were earmarked for professional attention and research. Each sector was assigned a coordinator (a specialist in the field) and five professional research assistants. Over time these teams were to prepare comprehensive, interdisciplinary reports on how the identified objectives could be applied to the individual sectors. The plan was viewed as a tangible vehicle to help guide the government's role in protecting Costa Rica's natural resources for long-term, sus37

tainable use. Implementation and enforcement of its recommendations are underway, but time and ecological restoration will be the litmus test of its success.

The Strategy's emphasis on balanced agricultural production is evidence that the government's attention to conservation during the past three administrations has not been limited to parks and reserves. Studies and practices of sustainable farming are an equally important contribution to Costa Rica's conservation history, especially given the largesse of the agricultural scene. Agriculture remains the country's number one industry-accounting for over half the country's land use and two thirds of 38

its national economy. Thus research, training, and development of sustainable practices have become important factors for farmers and policymakers.

A study that originated during the Arias administration came to have special significance on this subject. Entitled "Natural Resource Management in Costa Rica" (and partially funded by U.S.- 
AID), the study came up with a system of geographical land use capabilities (LUCS). It identified five land types "where the most intensive use that a piece of land is able to sustain on a continuous basis without suffering from degradation" was possible. The categories included land for clean-tilled crops, pastureland, permanent crop cover areas, forest, and protected reserves. Using soil studies, drainage data, topography reports, and climate information, the study was able to discern the size of each land use category and to define their locations across the country. This type of data had useful implications for for policy making. For example, the study showed that 4,656 square kilometers $(2,800$ square miles) were viable for pasture but that 19,000 square kilometers $(11,400$ square miles)--almost one third of the country--were presently being used in that ca39

pacity. It showed very graphically the degree of deforestation caused by the expansion of the livestock industry. But that the study identified the importance of agricultural land (three of the five LUC's) shows that conservationists were interested in more than just fencing off areas and taking land out of production. The goal was to show how production could be sustainable and less harmful to the environment.

Sustained development was also the theme of the Seventeenth General Assembly of the International Union for the Conservation of Nature (IUCN, presently called the world Conservation Union) that took place in San José in 1988. Members of the Costa Rican conservationist community were proud to host this event and show- 
case their accomplishments. They actively participated in differrent conferences and panels presented at the gathering of conservationists who attended from all over the world. Alvaro Umaña, for example, spoke on how "the concept of sustainable development" was an important "new style" of meeting the challenges of agriculture in the tropics. "It used to be that conservation meant preservation without [the presence] of man, that land should be kept in a bubble," Umaña stated, "but in Central Amer40

ica, that's not possible." It was at this conference that Costa Rica's first debt swap plan was announced.

President Arias also addressed the IUCN Assembly saying that his country "should feel satisfied and proud to bring its grain of sand to the future of life on this planet." But while saying that it was "with humility [Costa Rica] aspires to convert itself as a prototype of the new societies necessary to live together peacefully on earth," he also shared a revelation that was great cause for concern: the deforestation rate in Costa Rica was worse than previously believed. He reported that "no country in Latin America ha[d] a higher rate of deforestation" and that "less than five percent of the nation's dense forests exist[ed] outside of protected areas." Thus, he continued, Costa Rica's notable development of national parks was becoming offset by forest destruction--"a paradoxical situation constitut[ing] a serious threat to the advanced successes of conservation." The reality of Arias' words, and in fact the whole campaign for sustainable development, was the result of a satellite photog- 
raphy study that showed how acute the problem of deforestation was becoming. Instead of the eight to nine percent of forested land that aerial photos showed to exist outside of parks and reserves (bad enough as that was), the satellite images showed, 42 like Arias mentioned, that only five percent remained. The cause for such destruction was pasture expansion and logging. Alvaro Umaña explained to reporters that much of the logging was illegal and that he had ordered the Rural Guards to be put on duty to conduct surprise searches. Their work resulted in the discovery of illegal cuts in and around national parks, trucks hauling logs out of restricted areas by night, the common practice of hiding logs under agricultural produce on truck beds, and the common use of forged logging permits. The problem grew so out of hand that in 1988 officials from the Forestry Directorate petitioned President Arias to declare a national state of emergency. Agreeing to do so the following year, the proclamation empowered the DGF to suspend all permits to fell trees outside of private plantations and to prohibit the export of unfinished wood products. The declaration also freed government funds to beef up the enforcement of these policies, again making use of the Rural Guard. As to be expected, the timber companies reacted negatively and conservationists very positively to the measures.

At the root of the problem, policy-wise, was an obsolescent forestry code. In 1983 (during the Monge administration) the Legislative Commission on Agricultural and Natural Resource Affairs convened to consider a "total reform" of the 1969 Forestry 
Law. That law established national parks, forest reserves, and other land use limitations, but did not do much to control the logging or livestock industries--especially on private forested land. Diputado Carazo Paredes recognized the urgency of legislative reform and told fellow commission members that after seeing "more and more logging trucks" in the country, he was "worried that total deforestation" would soon follow "if we don't put a stop to it now." "If the forest disappears," he reminded the committee, "so will everything else." Later he told the committee that the reform was of special interest to him ("as a farmer and one-time wood cutter") and that the roads and trucks themselves were destroying the forests. He advocated the more sustainable use of selective cutting and the use of 44 oxen to pull logs out of densely forested areas.

There were others who supported reforming the Ley Forestal. Alexander Bonilla of ASCONA lobbied for its approval by emphasizing the problems of unregulated burns. The DGF supported it because it would grant that agency more power "to intervene against the exploitation of timber resources." Nonetheless, most debate on the bill centered around the question of regulating private property. The bill's focus was to enforce "forestry management plans" on property owners for the long-term benefit 45 of the environment and the industry. Three years later, after considerable discussion and amendments on these points, the commission sent the bill to the Assembly. It was approved there and signed into law in 1986. 
It hardly went over well in certain sectors of the public. The logging industry and various landowners complained that it violated the Constitution of the Republic by infringing on their rights as private property holders. Roxana Salazar, one of Costa Rica's leading environmental attorneys, explained that at issue was the right of the government to impose "Iimitations on private property." Those opposed to the measure presented several cases to lower courts, but because the matter was of a constitutional nature, it ended up being resolved by a Constitutional Tribunal (Sala Constitucional) made of Supreme Court judges. In 1990 the Sala ruled that the new Forestry Law did in fact violate Articles Forty-five and Forty-six of the Constitution by imposing the restrictions on private land. The Legislative Assembly had the power to make such a law, but it required a two-thirds vote on the third debate of the motion. The Assembly had approved the bill by a majority of thirty-seven votes in 1986--one vote short of the required two-thirds needed for constitutional issues. Thus, the Sala annulled the reformed Forestry Law and reincarnated its 46

1969 predecessor.

According to Salazar, the environmentalist community in Costa Rica did not react very strongly to the Sala's decision. "It was more of a blow to the government," she explained, in that legislative committees had to go back to the drawing board, a bill would have to trudge anew through the legislative process, and agencies like the DGF were denied the meaty authority needed to slow deforestation. Luis Fournier, on the other hand, was 
annoyed. Fournier, a member of the original committee that hammered out the Ley Forestal bill in the late 1960's, mentioned that the Sala's ruling was based "more on the letter of the law than on the spirit in which it was made." But, as he added, "you have to work with [the court's] decisions."

The work fell on the Legislative Assembly which raced to put a "band-aid" provisional law together until a new, authoritative forestry law could be enacted. A team of diputados prepared a study outlining the good and bad points of the 1986 law and what needed to be changed. The diputados' concluded that consolidating state forestry policy, more strongly regulating the logging industry, and filling in the gaps of the 1969 law were advantages of the recently anulled law that needed to be continued but that its constitutional faults outweighed any benefits accrued. Thus, as "a very urgent" measure they proposed an alternative forestry policy that arrived at a plenary session of the Assembly on June 5, 1990--an apropos date since it was the International Day of the Environment, a point aptly exploited by more than one speaker during that session.

The proposed law's principal objective was "to guard for the protection, conservation, exploitation, industrialization, administration, and development of the country's forest resources in accord with the principles of rational use of renewable natural resources." The bill gave the DGF authority over those broad responsibilities and established an interdisciplinary Forestry Coun- 
cil (in some ways similar to the one José Figueres had created in 1949) to serve as an advisory committee for policy implementation. The Council was to be made up of various forestry industry associations, representatives of forestry cooperatives, university scientists, government agency officials, and was to be headed by the Minister (or Vice Minister) of MIRENEM. And finally, among other duties, the law clarified state and private forestry categories and how regulations would apply to each. The tone of the section on private property was one of encouraged cooperation. It urged industry representatives to maintain relations with government agencies and to participate in research and 49 policy forums.

As in 1969, speakers supporting the proposed law on the floor of the Assembly exploited references to "future generations" and "for the future of all costa Ricans" as reasons why they were in favor of its passage. Diputado Castro Retana asserted that Costa Rica "could be a desert in five to ten years" without the law in place. Another Assembly member (Diputado González Salazar) looked backward and invoked "the memory of illustrious Costa Ricans who down through history had seen to the creation of laws to adequately protect our forests." He listed such figures as former presidents Cleto González V1quez (who in 1906 promulgated the first law giving the Assembly the power to create forest protection laws) and Jose Figueres who established the Forestry Council soon after the Revolution of National Liberation, and others in the 1950's and $60^{\prime} \mathrm{s}$. "Let's not shrug off 
this enormous responsibility," Gonzalez implored, "we know that this law is not perfect, but we also know that that which is 50

perfect is the enemy of that which is human."

Other Assembly members, however, were quick to point out that the proposed law did not seem too different than the 1986 version which was deemed unconstitutional. Even with his understanding that "we must do something," Diputado Aiza Campos felt like the emergency forestry law was nothing more than "some cosmetic changes" that would lead eventually to "the same error as the previous legislation." Diputado Múñoz Quesada thought that it was "perfectly possible" that the bill could be declared unconstitutional too but considered that the Sala's ruling on the old law could have been beneficial "because now we'll correct those matters." But like the other forestry bills preceding it, Law 7174 received wide support from municipal leaders and conservationists around the country and was approved by the Legislative Assembly after a third reading on June 28, 1990.

It was approved with provisions. The most important one for this study was Provision VI which, because the law was temporary in nature, required that a report be made by a "special commission. . . to study and propose reforms to the Ley Forestal." The commission was to convene immediately upon passage of the 52

bill and had but two months to issue its report. The commission got right on the job, but in the meantime there had been a change of government with the election of Rafael Calderón as President. Oscar Arias left office after having revamped the government's 
public lands managment and environmental agencies (i.e. MIRENEM, URC's), after having supported the protection of tropical dry forest ecosystems with the Santa Rosa expansions and the creation of Guanacaste National Park, and after having overseen the integration of sustainable development policies within protected lands' management programs.* Before his term expired he also decreed the creation of Arenal National Park (the home of Arenal Volcano --the country's most consistently active volcano--in the Tilarán Mountains not far from the Monteverde Cloud Forest Reserve**), and he created InBio--the National Biodiversity Institute to inventory the nation's biological wealth (see chapter 11).

The new president, Rafael Calderón Fournier of the conserva-

* David Wallace (Quetzal and Macaw, p. 116) relates how one of Arias' last environmentally oriented duties in office was to attend the historic, internationally commemorated Earth Day rally (marking the twenty years that had passed since the big Earth Day celebration in 1970) on April 20, 1990 at the Plaza de la Democracia in San José. Ironically, the event took place on the same day that the Burger king fast food chain (a major importer of Costa Rican rainforest beef) hosted the grand opening ceremony for its first franchise in Costa Rica which attracted a larger crowd than did the Earth Day rally.

** It took several years to complete all the land expropriations for Arenal's official opening as a national park. The courts nullified the proclamation because Arias had decreed the park's creation before all the landowners had consented to sell. Today it is a restricted-access national park because of the severe danger the eruptions present. Several scientists and climbers have died trying to study its geological mysteries. The park also represents part of a corridor protection plan of endangered cloud forest ecosystem in the Tilarán range as it is linked with the Children's Rainforest project and the Monteverde Preserve. Located at the east end of Lake Arenal (Costa Rica's largest producer of hydroelectrical power), the park's mission is also to protect the densely wooded slopes surrounding the volcano as a means to reduce the lake's growing siltation problem which was caused by deforestation in the area. 
tive United Social Christian Party (PUSC), was the son of exPresident Rafael Calderón Guardia (arch-rival of "Don Pepe" Figueres in the $1940^{\prime} \mathrm{s}$ ) and the godson of ousted Nicaraguan dictator Anastasio Somoza. He was elected President in 1990 after two unsuccesful tries in the previous elections against PLN winners Luis Monge and Oscar Arias. He won this time in a very close and bitter race with the help of campaign manager Roger Ailes (the mastermind behind George Bush's negative campaign for president against Michael Dukakis two years earlier) who worked to link the PLN with complicity in narcotrafficking and had Calderón appeal to the populist sentiments of campesino voters. Calderón's conservative resume and positions logically worried Costa Rican conservationists. They were further alarmed when the environmental group ASCONA came out with reports that Calderón's PUSC supporters in the Osa Peninsula had promised area oreros access to Corcovado National Park. Calderón denied the charges, but the director of the park told reporters for the Tico Times that "We've identified these people as Calderon people, and they were telling the goldminers that Corcovado National Park would be given to them."

\section{3}

Calderón did not mention Corcovado gold panners in his inaugural speech, but he did talk about preserving Costa Rica's "untold ecological riches" and his interest in creating a "new ecological order of international cooperation." These words surprised conservationists since in none of his three campaigns for President had he ever given much attention to environmental con- 
cerns. But he did make some appointments which seemed to please the conservationist community. While he named outsider Hernán Bravo (a beverage company executive from Cartago) as the new Minister of Natural Resources (MIRENEM), he appointed Mario Boza as MIRENEM sub-director, he retained Alfonso Matamoros as head of SPN, and named Alvaro Ugalde as head of the Wildlands and Wildlife Department--a newly created office that was part of the administration's reorganization scheme. Ugalde was transferred back to the directorship of SPN in the spring of 1991--less than a year into Calderón's term--to utilize his expertise in the dayto-day management of the park system.

Back in the government saddle again, Boza and Ugalde wasted no time in working to influence conservation policy. The most important policy under consideration at the time was the reworking of the emergency Forestry Law that the Legislative Assembly's Special Commission was engaged in during that summer of 1990. When Boza was called on to testify before the commission on July 28 he brought his slide projector with him. In it were pictures rendered from the Land-Sat images that had been taken from over five hundred miles above the Earth which showed the extent of Costa Rica's deforestation problem. Edward Cyrus, chief of MIRENEM's Technical Services Department, also came to the meeting to interpret some of the satellite images. He talked about the waste involved in deforestation and explained that while sixtythree percent of the timber cuts were destined for industrial purposes, in reality only thirty-four percent of the wood made it 
to the industries and of that, only seventeen percent was converted into "products that reach the consumers." Thus, Cyrus pushed the need to legislate for "a more efficient timber indus54

try." Also present were DGF officials José Luis Salas and Luis

Angel Villalobos who spoke more about their department and fielded questions from commission members.

The commission members were receptive to the data presented to them. They had recently learned that there were only 250,000 hectares $(617,500$ acres) of forest remaining in Costa Rica outside of protected areas. This number was down from the estimate of only a few years previous that indicated that 400,000 hectares (988,000 acres) remained. They knew, then, that Boza was not exaggerating when he told them that his office received "letters daily from all over Costa Rica from groups and citizens who were worried and upset about deforestation in their area." He continued,

The people say 'come, see this, do an investigation, stop the culprits, buy out the land, position some guards,' which is almost impossible for us to do. . . we just don't have the economic means . . to acquire more land, which is the only effective protection in this country. . . The people beg for more surveillance, but we're constantly losing park guards, and guard positions. We're tied down. On the one hand, exploitation continues and the people clamor for more conservation, but everyday we have less personnel, fewer funds to complete the job. We have reached a period of great crisis in this respect.

Therefore, he urged the commission to pass a tough forestry bill on to the Assembly--"an effective instrument to manage what natural forest we have left." "Let's not let the last 250,000 hec- 
tares disappear," he said ending his prepared remarks.

It was at this particular hearing that Boza introduced a compelling new argument: changes in land use were the most destructive for the environment. He showed that farming, ranching, and logging could occur in certain areas without ecological damage because the land was being properly managed for those uses. He cited how Portico (a private enterprise) and CATIE regularly practiced such wise use strategies, but did not change the land use patterns once operating in a renewable, sustainable way. It was when a radical change took place (i.e. clearcutting) that the long term damage started to mount which eventually affected not only the forest but also caused erosion, flooding, and loss 56 of hydrologic resources.

A question and answer session followed Boza's presentation. Because the commission members' questions reflected their and their constituents' concerns regarding forestry regulations, they are important to consider here. Several diputados wondered how landowners could get permission to cut any wood at all on their places. Boza responded that the regulations would have to vary from region to region. Diputado Daniel Gallardo was especially concerned for the small farmers in his district from whom he had received protests because they had been denied permits to cut wood for buildings and fenceposts while their neighboring big landholders "cut indiscriminantly." Acknowledging the problem, Villalobos answered that one of his department's concerns was 
that often small farmers did not have "adequate certification" of land ownership and that soil types had to be taken into consideration. Boza also mentioned that organizations like the OTS were studying reforestation issues and were experimenting with different tree species (especially the chancho tree) that seem to grow very rapidly as good news for both small and large land-holders. Gallardo wanted to know if any areas of the country were being considered completely off-limits to woodcutting and if more private organizations were getting involved. Boza listed several groups that were engaged in the deforestation crisis and highlighted how Amigos de Lomas de Barbudal (Friends of the Barbudal Hills Biological Reserve) had been actively and effectively managing that protected area in the Lower Tempisque drainage region of Guanacaste for two years. He said that MIRENEM was starting to look more closely at such private "contract management" ideas for other areas as well. Gallardo also expressed his concern for animal life in deforested areas. Boza responded that "what is happening . . . is a disaster" and explained how his office received complaints every summer about how some farmers burn forests--including parts of national parks--just to drive deer. The greatest problem according to Boza, however, was still with agricultural colonization and specifically with the IDA (Agrarian Development Institute, formerly ITCO) which continued to help peasant families move onto public lands without suitable guidelines on sustainable farming and forestry. Salas also reminded the committee that several campesino groups had formed to 
demand sustainable practices and had reforested 9,900 acres in 1989 alone. And Villalobos added that within the DGF was a Department of Campesino Forestry Development aimed especially at assisting rural people in need. He also related how the DGF was pushing hard for reforestation of native species--for management of "natural forests" as opposed to teak-wood or other non-native tree species. Boza closed the presentation by reiterating the importance of including "no change of land use" language in the new forestry law. "Without it," he advised, "we have nothing legal to enforce the law; it is absolutely vital to incorporate it into this legislation." 58

The Special Commission continued to meet into the fall of 1990 and on into 1991. Evidently the two month deadline had been extended since more testimony was entered into the record and deliberations continued for the next few years. Mario Boza addressed the committee members again in September 1990 with a renewed concern about Corcovado National Park. Mincing no words, he said, "either we do something very soon,. . or within four to five years [the park] will be an island surrounded by pastures." He informed the legislators that 1,000 hectares $(2,470$ acres) of forest a year were disappearing from the osa Peninsula and that MIRENEM was considering creating an Emergency Forest Zone around the park. The committee later heard testimonies from Tirso Maldonado from Fundación Neotrópica and Raúl Solórzano from the Tropical Science Center on efforts their organizations were doing for reforestation and suggestions they had for a new 
forestry law. They stressed the need for a "more effective" concession granting process for forest cuts and more penalties (dis59

incentives) for deforestation.

The testimony of Boza and others before the Special Commission reflected the evolution of conservation thought in the early $1990^{\prime} \mathrm{s}$. The concern for the area surrounding Corcovado National Park was more than just arguments for buffer zone protection, it inhered a concern for optimal park size. Conservationists like Boza and Ugalde were now questioning what could be the ideal park size for protecting an entire ecosystem. New MIRENEM Minister Hernán Bravo addressed this concern in a letter to Special Commission chairman william Cordero in which he told of how his agency was working to create "conservation areas" (an expanded version of the URCs from the Arias administration).

Along those lines, then, Boza prepared the Renewable Resources Action Plan for the Calderón Administration. In it he wrote that the "ultimate goal" was to maintain twenty-five percent of Costa Rica's forests outside of protected areas. It advocated integrating national wildlife refuges into a park system that would link biological reserves, national parks, and forest reserves into these large conservation areas.* Its long-

* Alvaro Ugalde, who headed the Wildlife and Wildland Department for one year in the Calderón administration, explained to David wallace (Quetzal and Macaw, p. 188) why Boza preferred incorporating wildlife refuges into national parks: "In Latin America, Fish and Wildife is perceived as a little bureaucratic office with no political support, no support of any kind. That's been the case in Costa Rica. It used to be the Fish and Wildlife Service--'Fish' meaning basically fishing, and 'Wildlife' meaning 
range goal was to form a corridor of forested areas in Costa Rica that would connect with protected areas in Panama to the south and with Nicaragua to the north, and eventually to form "a biological migration corridor throughout Mesoamerica." The plan also included sections on ecotourism and environmental education and proposed that ICT (tourism institute) be actively involved with planning and promoting the protection of natural areas. To accommodate ecotourists better, Boza wanted the Ministry of Public Works to improve roads to national parks and for private foundations to become more active in park management (along the lines of the successful Monteverde and Lomas Barbudal 61 experiments).

Meanwhile, President Calderón was working to advance another item on his administration's conservation agenda: promoting costa Rica to be the headquarters of a proposed Earth Council as part the "New Ecological Order of International Cooperation" that he had alluded to in his inaugural address. The plan was to present such a proposal in the form of a resolution to the U.N. Conference on the Environment and Development (the "Earth Summit") that was held in Rio de Janeiro in June of 1992. The plan also had the support of the delegates from other Central American nations who co-sponsored the resolution. MIRENEM Minister Hernán Bravo, head of the Costa Rican delegation to the conference, introduced the resolution which outlined how Costa Rica could be the ad-

basically white-tailed [sic] deer research, and hunting permits and seasons. Very symbolic activities." 
ministrative seat of the Earth Summit to follow up on agreements reached in Rio de Janeiro. And in a speech to the assembled delegates, President Calderón stressed how Costa Rica had been "fighting to attain the ideal of development with a human face and in harmony with nature." Boldly inviting the rest of the world "to emulate Costa Rica. . [where] ecology enjoys a long tradition and solid prestige," Calderón stressed how his country was committed to the task of hosting the Earth Council. "Our government, following the dictates of its own convictions and the desires of its citizens," he proudly concluded, "has put special emphasis on accelerating programs in this [environmental]

field." The international delegates, made up of over one hundred heads of state and over 9,000 representatives of NGO's and other 62 groups, approved the resolution.

In addition to the honor hosting the Earth Council bestowed on Costa Rica in recognition of its active commitment to environmental conservation, many Ticos believed that the Earth Council would generate important economic and educational resources for the benefit of the country. Full page ads in Costa Rican newspapers congratulated President Calderón and Minister Bravo for their efforts and success in Rio. An editorial in La Nación soon after the U.N. conference proclaimed that

Calderón has obtained his greatest foreign policy victory with the Rio Summit's designation of Costa Rica as the permanent seat of the Earth Council. We are converting ourselves as a nation into one of the principal centers of world ecology. (63)

Not everyone agreed with this assessment. Leaders of Costa 
Rican environmental groups were quick to point to contradictions in policy. ASCONA's César Castro (who during the presidential election had called Calderón's plan "a campaign trick"), maintained that "the government is scrambling for eleventh-hour strategies." The director of the Costa Rican Ecological Association, Orlando Avila, called the idea "demagogic and opportunistic" and was more succinct in his specific criticism: "While the government is promoting Costa Rica abroad as a model of environmentalism, the rape of natural resources continues at home without the political will to stop it." And Guillermo Barquero of the National Organization for Wildlife and Conservation, who had earlier called Calderón's Earth Council idea "a rhetorical plan," now stated that "Costa Rica is creating a myth, without meaning or content in practice, in legislative and environmental policy." Likewise the conservationists complained that the environmental groups had not been consulted in the planning process of 64 Calderón's proposal.

There is a sidenote to the story that produced bold headlines in Costa Rican newspapers at the time. The government discovered soon before the start of the Rio Conference that a resort project under construction on Costa Rica's far southeastern Caribbean coast had improperly crossed (or had ignored) the legal boundaries of the Kekoldi Indigenous Reserve and of the GandocaManzanillo National Wildlife Refuge. The resort, to be called "Ecodesarrollo" (Ecodevelopment), however, was the project of Maurice Strong--the Canadian businessman and self-proclaimed 
environmentalist who had brainstormed and organized much of the Earth Summit in Rio. Pictures of the bulldozed area crossing the property lines of the protected areas were emblazoned across front-pages and added to the irony of the timing. Strong later claimed that the whole affair had been blown out of proportion in that the bulldozer had inadvertently crossed into a protec65 ted area and caused little ecological damage.

Strong's alleged transgressions notwithstanding, the Earth Council did headquarter in Costa Rica following the Rio Conference. Original plans called for the seat to be located at the Universisity for Peace near Ciudad Colón (because of its [partial] U.N. sanction, its emphasis on environment and peace, and its location in a beautiful setting) but instead the Consejo de la Tierra was set up in a vast office space on the eleventh floor of a government building in San José. The arrangement was temporary. Plans as of 1996 were for the construction of a new headquarters building to be completed by the turn-of-the-century that would be designed to use solar energy and other environmentallyfriendly construction concepts. According to one official there, the organization has and will continue to benefit the host country as was originally hoped by its proponents in the Calderón administration. Fifty percent of the employees who work there are Costa Rican (and, as the official assured, they are not solely in secretarial and janitorial positions--they include department chiefs, administrators, assistants, etc.). 
Likewise, plans for constructing the Council's new facility include using only local materials and local firms.

The Earth Council's mission is "to operationalize the Earth Summit agreements and sustainable development through the empowerment of civil society." Its charter calls for "a world-wide participatory process. . . that will guide people and nations. . . [and] will be the Sustainable Development equivalent to the Universal Declaration of Human Rights." In 1997 it will convene a "Rio + Five" assessment conference "to evaluate progress (or lack thereof)" of the Earth Summit's recommendations. It will also "highlight the best sustainable development practices and research . . articulate values from these best practices, . . [and] assess the impact of international conferences on global governance for sustainable development" among other goals.

Two Costa Ricans serve on the Council's executive secretariat: Francisco Mata as the Deputy Executive Director and Lorena San Ramón as a Programme Coordinator. Gerardo Budowski serves as a representative to the Earth Council Institute and former MIRENEM Minister Alvaro Umaña is an institutional representative from the Central American Institute of Enterprise Administration where he currently serves.

President Calderón's success at landing the Earth Council in Costa Rica was not matched by the passage of a new forestry law during his term. That legislation would have to wait for the administration of José María Figueres who became President in 1994. With the new administration came new appointments to conservation 
positions and a continued restructuring of environmental agencies. Mario Boza left MIRENEM for a position with the Caribbean Conservation Corporation (CCC) in its San Pedro office. He became director of CCC's "Paseo Pantera" project that continues the work he started with his MIRENEM Action Plan to connect green corridors throughout Central America. Alvaro Ugalde left the National Park Service to work for the U.N. Environmental Programme (UNEP) whose Central America office is located in Pavas, a San José suburb. Hernán Bravo left MIRENEM to serve in the Legislative Assembly after winning a seat from his home district in Cartago.

President Figueres replaced Bravo with René Castro who oversaw his ministry's change of nomenclature and direction. When MIRENEM became MINAE (Ministry of Environment and Energy) in 1996, the agency combined the SPN, DGF, and Wildlife and Wildlands office into one subagency called Sistema Nacional de Areas de Conservación (National System of Conservation Areas, or SINAC). The government leased a large 1950's-style mansion two blocks from the MINAE tower to house SINAC's offices that formerly were scattered at DGF and SPN facilities elsewhere.

Part of the reason for the reorganization project was due to the multiplicity of bureaucratic agencies. Between the office of the President, the Legislative Assembly, and the "megastructure" of environmental agencies involved, there was, according to UCR biologist Sergio Salas who often worked with government agencies, "too much diffusion of responsibility." And because of 
institutional jealousies, the practical absence of interinstitutional coordination, and the difficulty of having interdisciplinary teams within the planning agencies. . . there exists competition between the institutions that diminishes their overall efficacy. As a final result, we see a growing ineptitude between the government, its employees, and the environment. (68)

By the early 1990 's there were twenty-seven different divisions, councils, offices, institutes, and juntas that, according to one outside study, worked "at cross purposes and almost never act [ed] in cooperation with each other." The different offices often had conflicting or overlapping results. The study contended that the problem stemmed from how different departments were created during different administrations (each with its own political pressures and lobbies) and how it proved easier to launch new agencies than to regroup existing ones. Further, many ministries developed their own environmental sections in response to the 69 duties the state required they perform.

The creation of MIRENEM as an umbrella organization did not seem to correct the problem. One study in the late 1980 's concluded that agencies were "swimming in information [and] overspecialization" and that the "multitude of policies" and "numberless agencies" represented "expansion without concept." Even the assistant to President Calderón's minister of MIRENEM, Eric Ulloa pointed out that there was

too much duplication of efforts, especially between MIRENEM and MAG. Likewise, we have a commission on Women in the Environment and recently the office of the First Lady [Señora de Calderón] has created a similar council. We want coordination, but it has not happened yet. (71) 
There was also duplication of efforts within certain departments via planning commissions, councils, and committees with overlapping responsibilities.

Thus SINAC was the result of the government's drive to restructure and decentralize conservation policy in Costa Rica. It was a direct descendant of the URC (regional conservation units) concept started at the tail end of President Arias' term. Like the URC'S, the new system divided the country into ten Conservation Areas (called los $A C$ ) based on geographical characteristics (See map, Figure 2.) Each AC was assigned its own director to be over several subdirectors charged with promoting conservation policy for different parts of the area. A "visión-mision" statement issued by the new agency defined SINAC's vision to be "an organized and consolidated leader that offers efficient service . . in management and conservation of natural resources, with the goal of contributing to the improved quality of life for the the country's inhabitants." Its mission was "to consolidate a National System of Conservation Areas, integrated and planned with other MINAE agencies where authority and duties will be delegated to the regions to give wider participation to the local society. . " Or, as SINAC literature proclaims, its goal is to follow "the three 'd's"--"de-concentration, decentralization, and democratization" of the nation's conservation policies.

In many ways the new SINAC system was a continuation of past conservation experiments. René Castro called it "an ongoing process" originating with the creation of MIRENEM and approved by 
FIGURE 2: Costa Rica's System of Conservation Areas

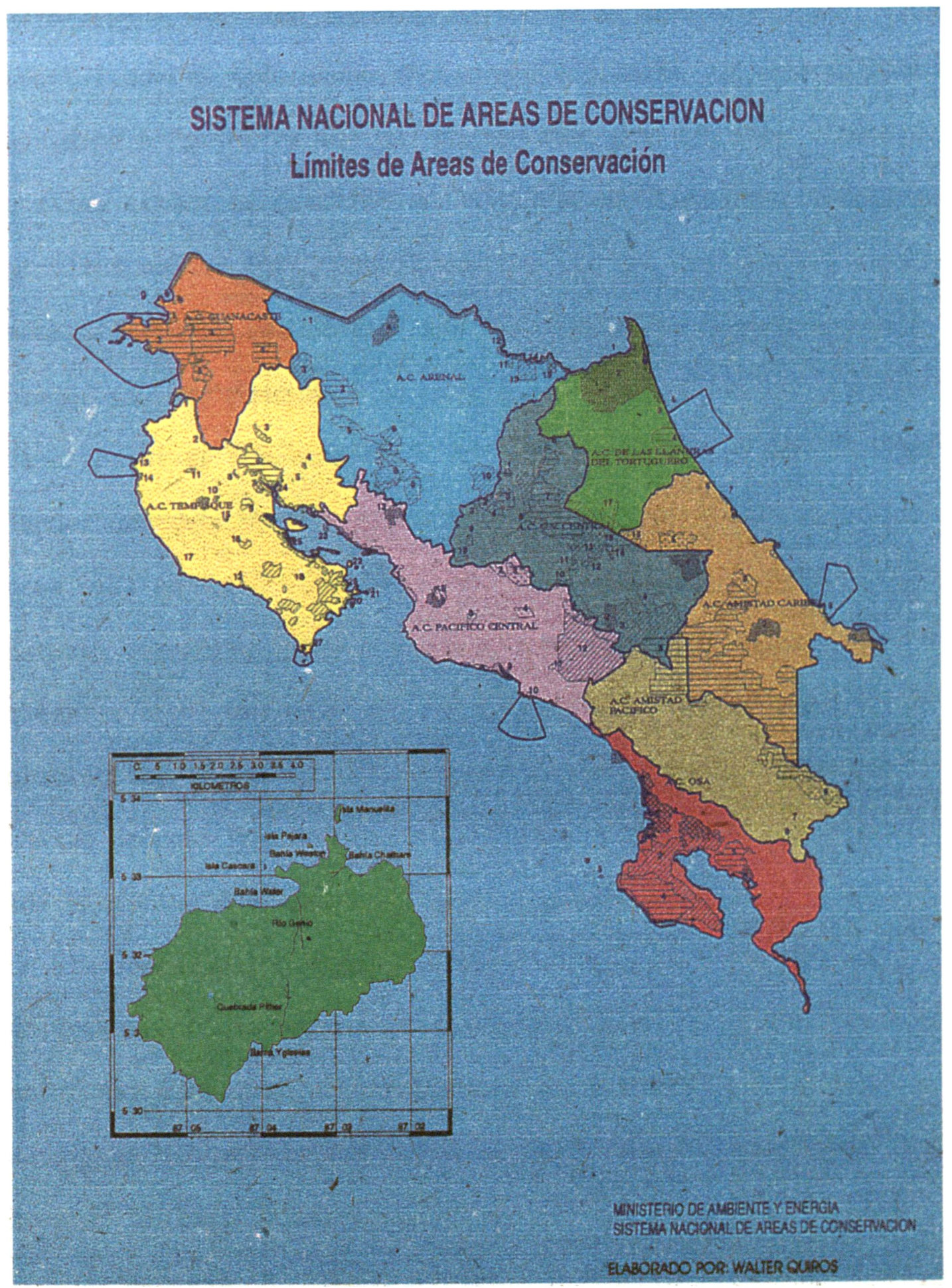

(Source: SINAC [used by permission]) 
the government planning office and the state Commission on Reform. Underlying the whole concept was the theory of sustainable development that was launched in the Arias administration. President Figueres made known that promoting sustainable development would be a "priority action" during his term and that it would be 73 a vital aspect of creating an "Alliance with Nature." SINAC's objectives called for "controlling the use and sustainable management of natural resources," and for "promoting the sustainable use of [those] resources in accord with the social and economic development of the country." AC's were defined as regions where "under one development strategy . . private and state activities will be interrelated for the management and conservation of natural resources and for seeking sustainable development solutions. . . " And the goal of democratizing the process by including the voices of local people in each region's decisionmaking process harkened back to Daniel Janzen's principles for administering Guanacaste National Park but extended the concept to all conservation areas in the country. Finally, the agency's objective "to guarantee the conservation of the nation's biodiversity" was a product of the push in the mid-1980's to protect ecosystem bioregions and buffer zones for the free transfer of 74 diverse biological services.

At stake with the new system's eloquent, if not redundantlyworded, goals was whether a policy that advanced "economic development" via sustainable use of natural resources could mesh with the ideals of "conserving biodiversity." The apparent contradic- 
diction was not lost among some conservationists.* Speaking to

that very point earlier when the URC system was inaugurated, former parks consultant James Barborak expressed that his concern was that "they're going to draw down something [the national park system ] they've done well to bring up . . . So, do you want the parks to go downhill in a general trend of everything going downhill? Or do you at least keep your islands green?" He explained that he was worried that parks and preserves would lose protection with plans to consolidate the agencies

like something they've never managed to do in the United States--to combine the Park Service, Forest Service, and Bureau of Land Management in one bureaucracy. That to me is the most troublesome point of everything that's going on right now. Everyone has caught on to sustainable development--it's the buzzword of the moment--but I'd like to see the cores assured. (75)

More recently, the environmental group AECO (Costa Rican Ecology Association) has been an outspoken critic of the reorganization scheme and has criticized the duality of SINAC's mission. AECO director Alvaro León explained in a recent interview that

\footnotetext{
* Somebody who has duly noted this type of inherent contradiction (not specifically for Costa Rica, but for places throughout the world in general) is environmental historian Donald Worster. In his essay "The Shaky Ground of Sustainable Development" (in The wealth of Nature, p. 144), Worster writes that "Like most popular slogans, sustainable development wears thin after a while, revealing a lack of any new core idea. Although it seems to have gained a wide acceptance, it has done so by sacrificing real substance. Worse yet, the slogan may turn out to be irredeemable for environmentalist use because it may inescapably lead us back to using a narrow economic language, to relying on production as the standard of judgment, and to following the progressive materialist world-view in approaching and utilizing the earth, all of which was precisely what environmentalism once sought to overthrow."
} 
one of his group's concerns was that the Directorate of Geology and Mines was not incorporated into SINAC--"excluding that agency from the decision-making process because of the boom in gold." Thus, with decentralized authority and increased local input, León contended, mining interests in the osa Peninsula were able to exert more influence in the management scheme of that $A C$ at the expense of the buffer zone protection goals and biodiversity preservation talk of SINAC officials. He also claimed that the plan would result in increased exploitation of resources, especially by the U.S. and Japanese paper industries, and increased construction of resort hotels in pristine areas--events that many local residents would actually oppose. So instead of increased local decisions, there would be increased external influence for economic development projects being exerted on regional AC personnel who could make their own decisions without regard for stricter national environmental standards, León said. Anselmo Flores Reyes, a native leader from the Térraba Indigenous Reserve on the west slope of the Talamancas in southern Costa Rica, corroborated León's point. He mentioned to this author that commercial deforestation continued to be a problem in and around the Térraba people's reserve: "There's a great deal of logging, watersheds are endangered, there are laws but they're not enforced, the wood-cutting regulations are not put into effect, the police do not help." He said he did not know much about the new reorganization system but mentioned that the forestry officials from the the regional AC office "do not visit 
very often; they go when they want and then don't do very much." In the past, however, Flores claimed that pre-consolidation DGF personnel regularly visited the area to inspect and control the woodcutters. He also mentioned that he knew of no indigenous people on any of the SINAC study commissions--the government 77 solicited little input from the Talamancan Térrabas.

AECO's Alvaro León voiced another concern his group had about the agency restructuring process: it had no legal foundation. He remarked that the Legislative Assembly had never passed any law allowing MIRENEM (or MINAE) officials to consolidate and regionalize the government's conservation arms. This point was also criticized by former MIRENEM official Eric Ulloa who during the Figueres administration was serving as a legistive assistant to Hernán Bravo, his former MIRENEM boss and now a diputado in the Assembly. "It's a fatal disaster!," Ulloa said of the whole SINAC organization, "it's never been approved by the legislature, it's part of the new president's goals [and] very typical of how this administration ignores laws." He went on to lambaste how MINAE had gone from one extreme of central coordination to the far other extreme of "way too much regionalism." But while calling it "nothing more than a matter of politics," Ulloa alluded to how the problem was actually deeper than political differences. He related how a decentralized SINAC was decreasing Costa Rica's prestige abroad among international lending organizations. The government of Canada, for example, "was so bothered" by the potentially environmentally harmful policy 
changes that it diverted a financial aid deal from Costa Rica to Nicaragua. The government of the Netherlands was considering a similar move, he said in the interview.* "Before the Rio Conference [Earth Summit], it was only Costa Rica," Ulloa remembered, "but now there's a lot of competition" for international funds. He also mentioned that Daniel Janzen was equally perturbed by the SINAC changes and was raising his own funds for projects at Guanacaste National Park. Thus, "the new restruc78 turing is not going very well," Ulloa concluded.

Environmental attorney Roxana Salazar disagreed with León's and Ulloa's contention that SINAC was an extra-legal entity. "No, there's no problem with legislative law," she rejoined, "MINAE can [legally] make changes" in the administration of the agencies under its domain. In fact, Salazar praised the direction SINAC was taking: "It's good; it's a different vision, more independent. . . that will allow greater local participation.". Forestry ecologist and conservationist stalwart Luis Fournier agreed with this assessment. The UCR professor admitted that there "will be problems at first," but went on to suggest that "local people know much more [than San José environmentalists]." In the long run, then, the decentralized policies "are 79 going to be a benefit in the future," he added.

Most conservationists and organizations contacted for re-

\footnotetext{
* MINAE Minister René Castro wrote in his report to the commismission studying the changes that he felt a benefit of the restructuring process would be "to guarantee international credibility to our donors." ("Proyecto de Reestructuración," p. 258.)
} 
search on this chapter concurred with Fournier. Fellow UCR biologist Jorge Cortés said that SINAC was "good" for bringing about more local input and keeping resources in the area instead of "disappearing" at the central office. He also applauded the agency's plans to hire area residents and to have conservation personnel living and working closer to the protected areas. Overall, Cortés thought SINAC would be "a benefit for national parks" but agreed that "corruption like [gold] miners" would continue to be a "difficult" problem to deal with. Gerardo Budowski said he liked "the idea of joining together" the different government agencies and "decentralizing the regions into one administrative organ." But, agreeing with Ulloa here, he warned that the changes could be "a pendulum [going] from one extreme to the other--there's the danger of losing central authority for policy control . . and the tendency to think on a short-term basis." Alexander Bonilla said he too "believe[d] in the importance of decentralizing--it will help, it's positive to have more spaces in which to promote conservation." But "it's going to take more than laws," he continued, "SINAC is good only if put into practice." stressing that sustainable development could be explained by understanding "society, economics, and ecology" as the three points of a triangle, Bonilla said that many groups look only at one point (he criticized enviromental groups for often seeing only the ecology point, "environmentalists are not the owners of truth"). Thus, SINAC was on the right track "to have connections with the private sector." But he also waxed a 
a bit more philosophical on the subject suggesting that "globalization" was "important to consider" for protecting the environment in places like costa Rica. "We have the right to develop," he concluded, "northerners do not have the right to complain." Another SINAC proponent, but one who came to support it a bit more slowly than others, was Mario Boza. In 1990, the Tico Times quoted Boza as having called the URC's "a mess" with a lack of "vertical organization." He said that he had spoken with a director of one of the units who could not even identify who his [the unit director's] boss was. Rodrigo Gámez, President Arias' advisor on natural resources, explained that while Alvaro Ugalde was "totally permeated with the [new] philosophy," Mario Boza was "more of a hard-core conservationist.. . [with] doubts about whether local communities [were] ready to have influence over the parks." Daniel Janzen agreed and said that Boza's reaction to the URC's was "to go back to the system he knew very well, which was, let's say more conventionally protectionist than very involved with people and management." Janzen mentioned that Boza's reactions could have been political since at the time he was out of government service during the Arias administration (belonging to the opposition political party). However, he continued, after having "an awful lot of people talking with him . . he's come to see that the old-style park as just a big pretty area managed by putting a fence around it isn't viable." Contacted for his more recent thoughts on the subject, Boza said that he was "in agreement" with SINAC--that it was "an old 
idea going back many years." He cited how he had been a member of the committee that originally had worked to bring it into existence. "It's underway," he stated, and "it's a better system with the regional input." He explained that he agreed with SINAC's work to dispel the "compartmentalization" theory of manag83 ing protected areas "like islands." Representatives of the conservation foundations where Boza had been so instrumental in the $1970^{\prime} \mathrm{s}$ and $80^{\prime} \mathrm{s}$ more or less agreed with this assessment. When asked about her organization's reaction to the SINAC changes, an official at Fundación de Parques Nacionales said that the new system had "advantages and disadvantages" but that overall FNP approved of it and supported it. An official at Fundación Neotrópica said "we're waiting to see." He stated that his organization was "more non-governmental" and that it would work with whatever changes the government came up with. "What's important," he said, "was to continue to apply for and receive grant money" to support Costa Rican conservation efforts.

Probably the greatest supporters of the restructuring process are MINAE and SINAC officials themselves. MINAE Minister René Castro wrote in his report to the commission studying the changes that "restructuring constitutes a necessary project founded in and coincident with the public interest of maximum use of existing resources. . . ." He listed a variety of benefits including flexibility in policy-making, reducing "operational distortions," and bringing "effective instruments" to the citizens to help with conservation efforts. And Rigoberto Ugalde, an 
official in the La Amistad AC, wrote that SINAC was "a model of 85 decentralized and participatory institutional management."

About at the same time that MINAE and SINAC started functioning as new agencies (1996), the Legislative Assembly finally passed a new and revised Forestry Law. The same Special Commission (albeit with different members across the years) had continued to meet to discuss the proposal and had convened over eighty hearings. On 29 January 1996 the revised Forestry Law made it to the plenary session of the Assembly where it was introduced into discussion by Diputado Ricardo Garrón Fuguls who had been the chairman of the special Commission. "It is a totally innovative project," Garrón began, "it completely changes the traditional concepts we have had regarding forestry laws." He went on to explain how the law would not see "forests as producers of wood, rather. . as an ecosystem that serves for the protection of watersheds, . . a protector of soils, . . a means to protect biodiversity, and as system with an enormous tourist potential."

Important points of the law included outlining the duties of a new Forestry Administration (within SINAC), i.e. conserving forest resources, approving management plans, establishing guidelines for the prohibited use of endangered tree species, and a variety of other administrative functions. The law created a National Forestry office and replaced the National Forestry Council with "Regional Environmental Councils" in the spirit of the government's decentralization emphasis. The councils would 
authorize wood cutting permits. Very importantly, different articles of the law dealt with conservation and reforestation incentives and various tax and penalty restrictions.

Perhaps one of the most important new tenets of the law was its language concerning forests on private land. Because it was the big stumbling block of the 1986 version, the issue had to be handled carefully, but firmly. Title III of the law specifically dealt with this point, and as would assuredly please Mario Boza who so cogently argued for its inclusion, spelled out that "on lands covered with forests, a change in the soil use of the area will not be permitted, nor will forestry plantations be estab88 lished." The wording was intended to impede the process of deforestation for agricultural purposes. Diputado Garrón explained to the Assembly that there would be two options available to owners of the 200,000 hectares (494,000 acres) of private forested land left in the country: 1 . the owners could leave their forests untouched and receive a [government] incentive "so that the land, we hope, will stay for eternity as forest;" or 2 . the landowners could "manage their forests--prohibiting the change of soil use" and every few years undergo an intense management review process. There was actually very little debate in the plenary sessions of the Legislative Assembly. One of the new Forestry Law's greatest proponents was Diputado Hernán Bravo who as Minister of MIRENEM under President Calderón had worked unsuccessfully to see it pass years earlier. He explained in one debate that the law would not prohibit logging, it would only change it to ensure a 
constant forest cover and to ensure against soil use changes. The law, he stated, "makes us look for how to protect the forest, not just the tree." It passed on 5 February 1996 by a vote of 90 forty-four to one. Eight days later, President Figueres, like his father before him in 1969, signed the forestry bill into law. The passage of the new Forestry Law and the implementation of the administrative restructuring process bring to a close another chapter in Costa Rica's conservation history. The next chapter in the future will have to evaluate these changes to see if they brought with them the hopes dreamed of by their advocates or the disadvantages predicted by their opponents. Certainly the examination will include the results of such policy implementations as called for by current MINAE Minister René Castro when he stated that his agency's mission was to promote "maximum use of natural resources." And certainly the verdict is still out on the application of sustainable development and its implications for Costa Rican conservation. These ideals and experiments await future debate and will be the center of studies for years to come. Meanwhile, it seems appropriate here to evaluate other, nonpolicy points in Costa Rica's conservation history as they apply to its development of a national environmental ethic. If we consider that conservation policies and institutions are the foundation of a green republic, then these other points (environmental education, non-governmental organizations, ecotourism, and biodiversity inventorying) are its building blocks. They are the subject of the next and final four chapters in Part II. 